
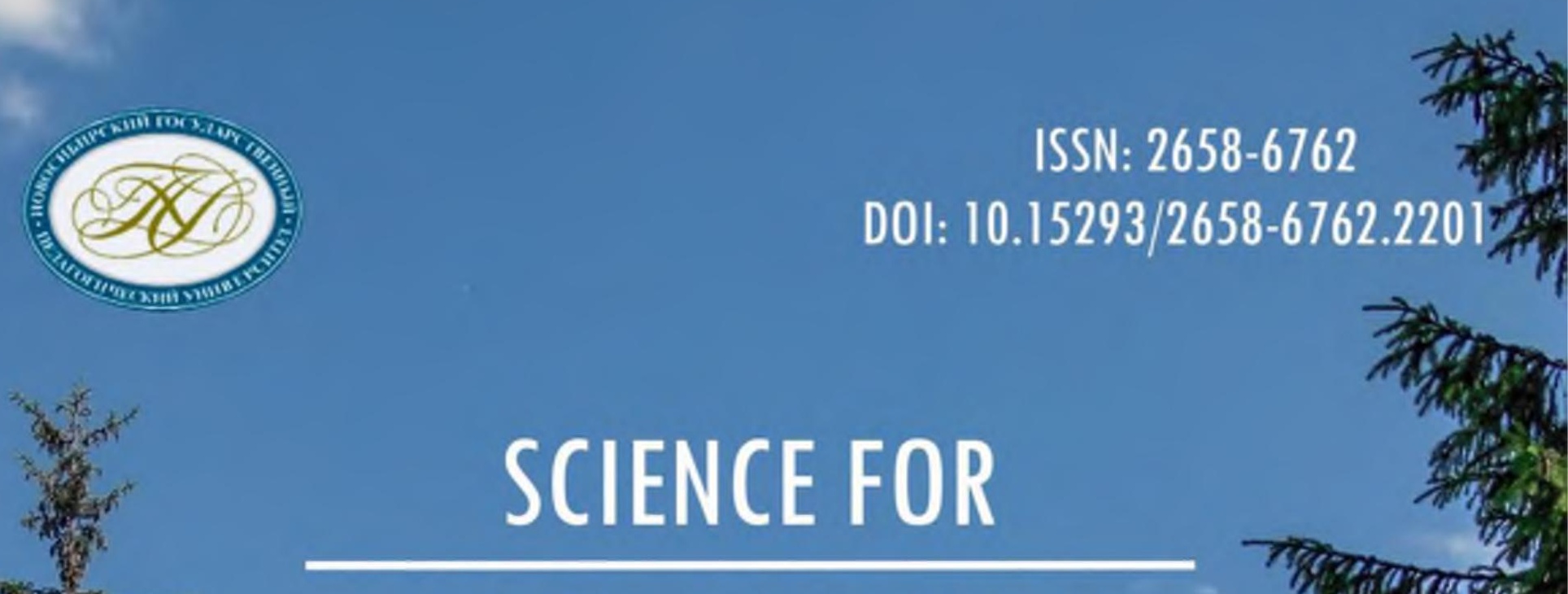

\title{
SCIENCE FOR
}

\section{EDUCATION TODAY}
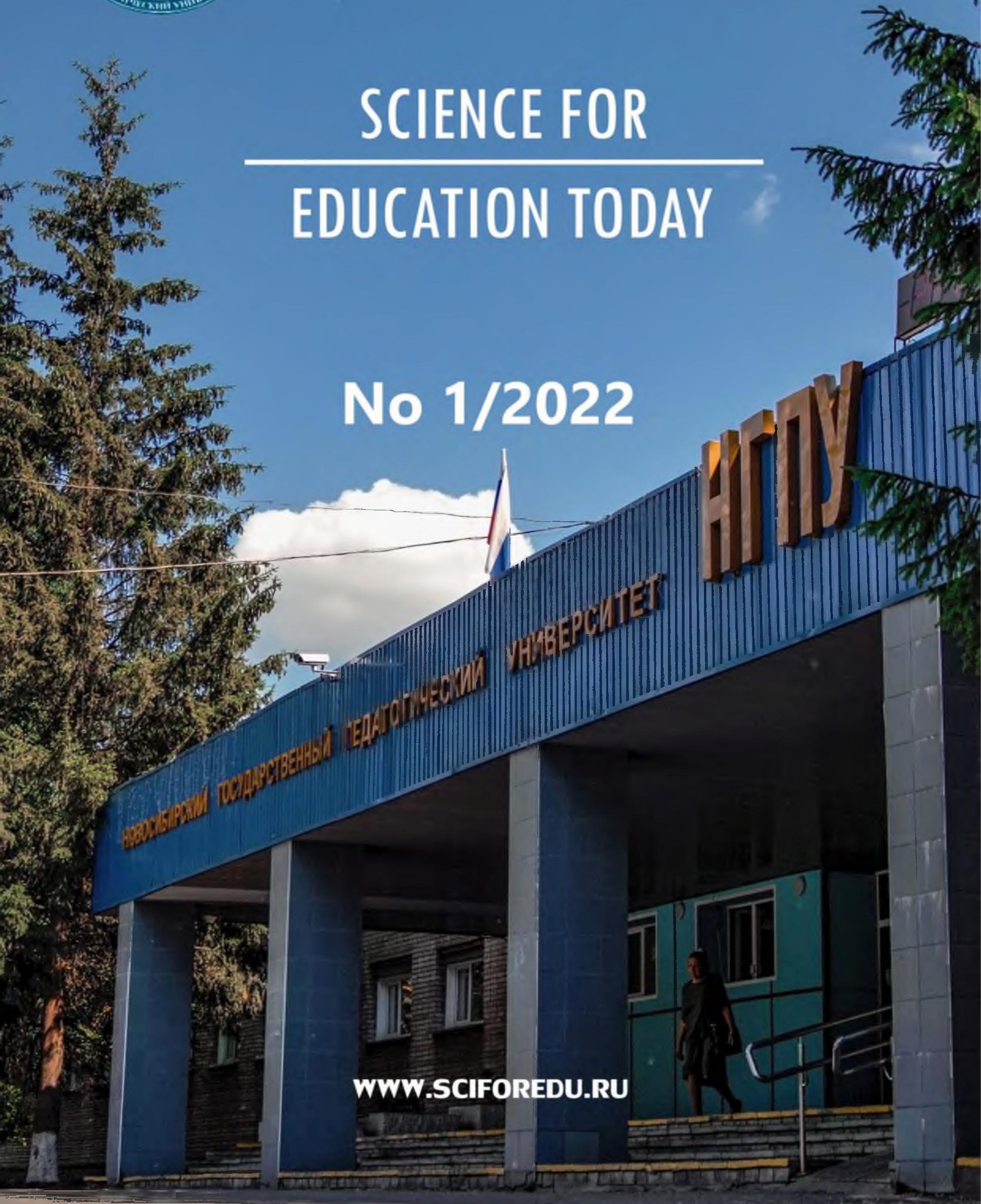
Учредитель и издатель:

ФГБОУ ВО «Новосибирский государственный педагогический университет» журнал зарегистрирован Федеральной службой по надзору в сфере связи, информационных технологий и массовых коммуникаций (Роскомнадзор) ЭЛ № ФС77-75074 от 11.02.2019;

включен в Перечень рецензируемых научных изданий ВАК; индексируется в: http://sciforedu.ru/vhozhdenie-v-bazy-dannyh

\section{Science for Education Today}

\section{РЕДАКЦИОННАЯ КОЛЛЕГИЯ И РЕДАКЦИОННЫЙ СОВЕТ}

\section{Редакционная коллегия}

главный редактор

Пушкарёва Е. А., д-р филос. наук, проф. заместитель главного редактора Майер Б. О., д-р филос. наук, проф.

педагогика и психология для образования

Богомаз С. А., д-р психол. наук, проф. (Томск) философия и история для образования

Майер Б. О., д-р. филос. наук, проф. математика и экономика для образования

Трофимов В. М., д-р физ.-мат. наук, проф. (Краснодар)

биология и медичина для образования

Айзман Р. И., д-р биол. наук, проф., филология и культура для образования

Костина Е. А., канд. пед. наук, проф.

\section{Международный редакционный совет}

О. Айзман, д-р филос., д-р мед., Каролинский институт (Стокгольм, Швеция)

Б. Бухтова, д-р наук, Университет им.

Масарика (Брно, Чехия)

К. Бегалинова, д-р филос. наук, проф.

(Алматы, Казахстан)

С. Власова, канд. мед. наук, проф., Белорусский гос. мед. университет (Минск, Беларусь)

Ф. Валькенхорст, д-р наук, проф., университет Кельна (Кельн, Германия)

С. Мореау, д-р филол., Парижский университет просвещения (UPL) (Сюрен, Франция)

К. Де О. Капплер, д-р психол. наук, проф.,

Дортмундский ун-т (Дортмунд, Германия)

Ч. С. Винго, д-р мед. наук, проф., ун-т Флориды (Гейнсвилль, Флорида, США)

Х. Либерска, д-р психол. наук, проф., ун-т им. Казимира Великого (Быдгощ, Польша)

Д. Логунов, н.с., ун-т Манчестера

(Великобритания)

Ж. Мукатаева, д-р биол. наук, проф. (НурСултан, Казахстан)

С. Пальяра, д-р наук, Уорикский университет (Ковентри, Уэст-Мидлендс, Великобритания)

А. Ригер, д-р наук, проф. (Ахен, Германия)

Н. Стоянова, д-р наук., проф. (Милан, Италия)

А. Чагин, д-р филос., н. с., Каролинский институт (Стокгольм, Швеция)

Д. Челси, д-р филос., проф., (Уппсала, Швеция)

Й. Шмайс, д-р наук, Университет им. Масарика (Брно, Чехия)

Юй Вень Ли, д-р политического образования,

Пекинский университет (Пекин, Китай)

\section{Редакционный совет}

председатель редакиионного совета

Герасёв А. Д., Д-р биол. наук, проф. (Новосибирск)

Афтанас Л.И., д-р мед. наук, проф., акад. РАМН, вицепрезидент РАМН, Президент СО РАМН (Новосибирск) Безруких М.М., д-р биол. наук, проф., почетный профессор НГПУ, академик РАО (Москва)

Бережнова Е.В., д-р пед. наук, проф. (Москва) Галажинский Э.В., д-р псих. н., проф., акад. РАО (Томск) Жафяров А.Ж., д-р физ.-мат. наук, проф., член.-корр. РАО (Новосибирск)

Иванова Л.Н., д-р мед. наук, проф., акад. РАН (Н-ск)

Казин Э.М., д-р биол. наук, проф. (Кемерово)

Князев Н.А., Д-р филос. наук, проф. (Красноярск)

Колесников С. И., д-р мед. наук, проф., акад. РАН, заслуженный деятель науки РФ (Москва)

Краснорядцева О.М., д-р психол. наук, проф. (Томск) Кривощеков С.Г., д-р мед. наук, проф. (Новосибирск) Кудашов В.И., д-р филос. наук, проф. (Красноярск)

Медведев М.А., д-р мед. н., проф., акад. РАМН (Томск)

Прокофьева В. Ю., д-р фил. наук, проф., (Санкт-Петербург)

Пузырев В.П., д-р мед. наук, проф., акад. РАМН (Томск)

Серый А.В., д-р психол. наук, проф. (Кемерово)

Шибкова Д. 3., д-р биол. наук, проф. (Челябинск)

Шилов С. Н., д-р мед. наук, проф. (Красноярск)

Яницкий М.С., д-р псих. наук, проф. (Кемерово, Россия)

Основан в 2011 году, выходит 6 раз в год

Издательство НГПУ:

630126, Россия, г. Новосибирск, ул. Вилюйская, д. 28

E-mail: vestnik.nspu@gmail.com

Номер подписан к выпуску 28.02.22 
The founder

and Publisher:

Novosibirsk State

Pedagogical University
The registration certificate

in Federal Service on Legislation Observance in Communication Sphere, Information Technologies and Mass Communications ЭЛ № ФС77-75074 The Journal is included into the List of Leading Russian Journals Journal's Indexing: http://en.sciforedu.ru/journals-indexing

\section{EDITORIAL BOARD AND EDITORIAL COUNCIL Science for Education Today}

\section{Editorial Board}

Editor-in-Chief

E. A. Pushkareva, Dr. Sc. (Philosophy), Prof., NSPU

Deputy Editor-in-Chief

B. O. Mayer, Dr. Sc. (Philosophy), Prof., NSPU

Pedagogy and Psychology for Education

S. A. Bogomaz, Dr. Sc. (Psych.), Prof. (Tomsk)

Philosophy and History for Education

B. O. Mayer, Dr. Sc. (Philosophy), Prof.

Mathematics and Economics for Education

V. M. Trofimov, Dr. Sc. (Phys. Math.), Prof.

(Krasnodar)

Biology and Medicine for Education

R. I. Aizmam, Dr. Sc. (Biology), Prof.

Philology and Cultural for Education

E. A. Kostina, Dr. Sc. (Pedagogy), Prof.

\section{International Editorial Council}

O. Aizman, Ph.D., M.D., Karolinska Institute,

(Stockholm, Sweden);

B. Buhtova, Ph.D., Masaryk University (Brno, Czech

Republic)

K. Begalinova, Dr. Sc. (Philosophy), Prof., (Almaty,

Kazakhstan)

S. Vlasava, Ph.D., M.D., Belarusian State Medical

University (Minsk, Belarus)

Ph. Walkenhorst, Dr., Prof., University of Cologne

(Cologne, Germany)

C. Moreau, PhD in Language University of Paris

Lumières (UPL), (Suresnes, France)

Ch. S. Wingo, M. D., Prof., University of Florida

(Gainesville, Florida, USA)

Ch. De O. Kappler, Dr. Sc. (Psychology), Prof.,

Dortmund University (Dortmund, Germany)

H. Liberska, Dr. Sc. (Psychology), Prof., Kazimierz

Wielki University (Bydgoszcz, Poland)

D. Logunov, Ph.D., University of Manchester

(Manchester, United Kingdom)

Zh. Mukataeva, Dr. of Biol. S., (Nur-Sultan,

Kazakhstan)

S. M. Pagliara, Dr., PhD, University of Warwick

(Coventry, West Midlands, UK)

A. Rieger, Dr., Prof. (Aachen, Germany)

N. Stoyanova, Dr., Prof. (Milan, Italy)

A. Chagin, Ph.D., Karolinska Inst. (Stockholm, Sweden)

G. Celsi, Ph.D., Prof., Uppsala University, (Uppsala,

Sweden)

J. Šmajs, Dr. Sc. (Philosophy), Prof., Masaryk

University (Brno, Czech Republic)

Yu Wen Li, Ph.D., Prof., Peking University (Peking, People's Republic of China)
Editorial Council

Chairman of Editorial Council

A. D. Gerasev, Dr. Sc. (Biology), Prof. (Novosibirsk)

L. I. Aftanas, Dr. Sc. (Medicine), Prof., Academician of RAMS (Novosibirsk)

M. M. Bezrukih, Dr. Sc. (Biology), Prof. (Moscow)

E. V. Berezhnova, Dr. Sc. (Pedagogy), Prof. (Moscow)

E. V. Galazhinsky, Dr. Sc. (Psychology), Prof., Academician of RAE (Tomsk)

A. Zh. Zhafyarov, Dr. Sc. (Phys. and Math.), Prof.,

Corr.- Member of RAE (Novosibirsk)

L. N. Ivanova, Dr. Sc. (Medicine), Prof., Academician of RAS (Novosibirsk)

E. M. Kazin, Dr. Sc. (Biology), Prof., Academician of IASHS, (Kemerovo)

N. A. Knyazev, Dr. Sc. (Philosophy), Prof. (Kasnoyarsk)

S. I. Kolesnikov, Dr. Sc. (Medicine), Prof.,

Academician of RAS (Moscow)

O. M. Krasnoryadstceva, Dr. Sc. (Psychology), Prof. (Tomsk)

S. G. Krivoshekov, Dr. Sc. (Medicine), Prof.

(Novosibirsk)

V. I. Kudashov, Dr. Sc. (Philosophy), Prof. (Kasnoyarsk) M. A. Medvedev, Dr. Sc. (Medicine), Prof., Academician of RAMS (Tomsk)

(Novosibirsk)

V. Yu. Prokofieva, Dr. Sc. (Psychology), Prof. (St.Petersburg) V. P. Puzirev, Dr. Sc. (Medicine), Prof., Academician of RAMS (Tomsk)

A. V. Seryy, Dr. Sc. (Psychology), Prof. (Kemerovo)

D. Z. Shibkova, Dr. Sc. (Biology), Prof. (Chelyabinsk)

S. N. Shilov, Dr. Sc. (Medicine), Prof. (Krasnoyarsk)

M. S. Yanitskiy, Dr. Sc. (Psychology), Prof. (Kemerovo)

Frequency: 6 of issues per year Journal is founded in 2011

(C) 2011-2022 Publisher "Novosibirsk State Pedagogical University". All rights reserved.

630126, Russian Federation, Novosibirsk, Vilyuiskaya, 28

E-mail: vestnik.nspu@gmail.ru 
Science for Education Today

2022. том 12. № 1

www.sciforedu.ru

ISSN 2658-6762

\section{СОДЕРЖАНИЕ}

\section{ПЕДАГОГИКА И ПСИХОЛОГИЯ ДЛЯ ОБРАЗОВАНИЯ}

Смирнов А.В., Симонова И.А., Попп И.А., Максимова Л.А. (Екатеринбург, Россия).

Психометрический анализ результатов применения в Российской Федерации единой методики социально-психологического тестирования несовершеннолетних

\section{ФИЛОСОФИЯ И ИСТОРИЯ ДЛЯ ОБРАЗОВАНИЯ}

Ашилова М. С., Бегалинов А. С., Бегалинова К. К. (Алматы, Казахстан). Смена неолиберальной концепции образования в эпоху COVID-19 и перспективы постковидного образования .

Кузнецова М. В., Пушкарёва Е. А. (Новосибирск, Россия). Иноязычное образование в ценностном становлении личности: анализ развития и современное измерение содержания проблемы (обзор)

\section{МАТЕМАТИКА И ЭКОНОМИКА ДЛЯ ОБРАЗОВАНИЯ}

Рылеева А. С., Хомутникова Е. А., Еманова С. В. (Курган, Россия). Развитие soft skills у старшеклассников с применением цифровых инструментов

Шаламова Л. Ф., Марусяк Д. М., Владимирова Т. Н., Лесконог Н. Ю. (Москва, Россия).

Региональная модель подготовки педагогических кадров как объект исследования

\section{ФИЛОЛОГИЯ И КУЛЬТУРА ДЛЯ ОБРАЗОВАНИЯ}

Иксанова Р. М., Киреева З. Р., Саттаров Э. И., Сагитов С. Т. (Уфа, Россия). Изучение практик внедрения полилингвальной модели поликультурного образования на территории Российской Федерации

Карапетян С. Г., Киракосян А. А. (Ереван, Армения). Проблема семантической дислексии у младших школьников с общим недоразвитием речи 


\section{СОДЕРЖАНИЕ}

\section{PEDAGOGY AND PSYCHOLOGY FOR EDUCATION}

Smirnov A. V., Simonova I. A., Popp I. A., Maksimova L. A. (Ekaterinburg, Russian Federation). A unified methodology for psycho-social assessment of minors: A psychometric analysis of the results. 7

\section{PHILOSOPHY AND HISTORY FOR EDUCATION}

Ashilova M. S., Begalinov A. S., Begalinova K. K. (Almaty, Republic of Kazakhstan). The collapse of neoliberal concept of education in the COVID-19 era and the prospects for post-COVID education ....30

Kuznetsova M. V., Pushkareva E. A. (Novosibirsk, Russian Federation). Foreign language education and value formation of a personality: Analysis of contemporary trends and developments (review)....55

\section{MATHEMATICS AND ECONOMICS FOR EDUCATION}

Ryleeva A. S., Khomutnikova E. A., Emanova S. V. (Kurgan, Russian Federation). Developing soft skills in high school students using digital tools

Shalamova L. F., Marusyak D. M., Vladimirova T. N., Leskonog N. Y. (Moscow, Russian Federation). Regional model of teacher education as a research problem.

\section{PHILOLOGY AND CULTURE FOR EDUCATION}

Iksanova R. M., Kireeva Z. R., Sattarov E. I., Sagitov S. T. (Ufa, Russian Federation). Studying the practices of implementing a multilingual model of multicultural education in the Russian Federation

Karapetyan S. G., Kirakosyan A. A. (Yerevan, Republic of Armenia). The problem of semantic dyslexia in schoolchildren with general speech impairment 


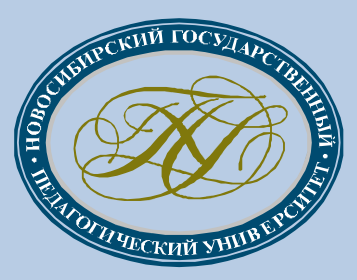

www.sciforedu.ru

\author{
ПЕДАГОГИКА \\ И ПСИХОЛОГИЯ \\ ДЛЯ ОБРАЗОВАНИЯ
}

\title{
PEDAGOGY AND PSYCHOLOGY FOR EDUCATION
}




\title{
Психометрический анализ результатов применения в Российской Федерации единой методики социально-психологического тестирования несовершеннолетних
}

\author{
А. В. Смирнов ${ }^{1}$, И. А. Симонова ${ }^{1,2}$, И. А. Попп ${ }^{1}$, Л. А. Максимова ${ }^{1}$ \\ ${ }^{1}$ Уральский государственный педагогический университет, Екатеринбург, Россия \\ ${ }^{2}$ Уральский федеральный университет имени первого Президента России Б. Н. Ельцина, \\ Екатеринбург, Россия
}

\begin{abstract}
Проблема и цель. Актуальность исследования определяется, с одной стороны, потребностью в профилактике и раннем выявлении девиантного поведения несовершеннолетних на фоне роста эпидемиологии и форм аддиктивного поведения в ряду других форм рискового поведения школьников и студентов, с другой стороны, отсутствием соответствующего диагностического инструментария, промедмего необходимые психометрические прочедуры. В настоящее время на территории РФ массово проводится Единая методика сочиально-психологического тестирования несовершеннолетних, имеющая целью выявление латентной и явной рискогенности сочиально-психологических условий, лежсащих в основе формирования психологической готовности к аддиктивному поведению у подростков и юномей. Целью исследования стало выполнение эмпирической проверки спектра психометрических показателей Единой методики социально-психологического тестирования несовершеннолетних (надежность, валидность, дискриминативность), выявление проблемных аспектов методики и «зон риска» ее применения в регионах.

Методология. Данные обрабатывались с помощью параметрических и непараметрических критериев связи, различий, согласованности (Пирсона, Стьюдента, Колмогорова - Смирнова, Манна - Уитни, Фитера, Кронбаха, Спирмена). Применялись различные виды статистического анализа данных (корреляционный, регрессионный, дисперсионный, факторный). Статистическая обработка данных проводилась как ручным способом, так и при помощи программного пакета «Statistica». Исследование проводилось в разных регионах России. Выборка составила 5100 человек.
\end{abstract}

Финансирование проекта: Исследование выполнено в рамках реализации государственного задания Министерства просвещения Российской Федерации 073-00042-21-02 по теме «Научный анализ применения единой методики социально-психологического тестирования обучающихся, направленного на раннее выявление немедицинского потребления наркотических средств и психотропных веществ, и ее доработка».

Библиографическая ссылка: Смирнов А. В., Симонова И. А., Попп И. А., Максимова Л. А. Психометрический анализ результатов применения в Российской Федерации единой методики социальнопсихологического тестирования несовершеннолетних // Science for Education Today. - 2022. T. 12, № 1. - C. 7-28. DOI: http://dx.doi.org/10.15293/2658-6762.2201.01

口 Автор для корреспонденции: Л. A. Максимова, maximova70@mail.ru

(C) А. В. Смирнов, И. А. Симонова, И. А. Попп, Л. А. Максимова, 2022 
Результатыл. Авторы выявили, что все три формы методики имеют высокие показатели синхронности, внутренней согласованности, устойчивости результатов, присутствуют факторы искажения результатов методики, связанные с возрастом, полом и регионом проживания испытуемых. Анализ описательной статистики показал достаточно высокий процент монотонных, стереотипных ответов. При сравнении результатов факторного анализа с содержанием базовых компонентов аддиктивной индивидуальности («самоконтроль поведения», «отношение к нормам», «направленность», «конфликтность», «стратегии преодоления культурного давления», «эмочиональная сфера», «наличие конфликта с сочииальной средой») обнаружено содержательное совпадение факторной структуры с содержанием этих компонентов. Сущуественные искажения в результаты диагностики вносит непропорциональное соотношение факторов риска и защиты во всех трех формах методики.

Заключение. Авторами на основе обобщения данных психометрической проверки обнаружены и описаны проблемные аспекты методики и зоны риска ее применения в регионах, на репрезентативных выборках определены основные показатели надежности, валидности, дискриминативности, предложены направления ее доработки.

Ключевые слова: рисковое поведение икольников и студентов; Единая методика соииально-психологического тестирования; факторы риска; факторы зашиты; ранняя диагностика.

\section{Постановка проблемы}

Проблема раннего выявления склонности к употреблению психоактивных веществ среди подростков и молодежи остро актуальна: сегодня выявляется ощутимая доля случаев их употребления школьниками, верхняя граница эпидемиологического диапазона более $18 \%$. Это заставляет вновь обращаться к теме диагностики и превенции аддиктивного поведения у данного контингента. С 2019 г. на территории РФ проводится Единая методика социально-психологического тестирования несовершеннолетних (далее - ЕМ СПТ), имеющая целью выявление латентной и явной рискогенности социально-психологических условий, лежащих в основе формирования психологической готовности к аддиктивному поведению у подростков и юношей. Массовое использование результатов методики при организации психологического сопровождения и профилактической работы с несовершеннолетними актуализирует как необходимость проведения научного анализа психометрических показателей ЕМ СПТ, так и определение «зон риска» методики и разработки рекомендаций по их минимизации.

Аддиктивное поведение - рецидивирующее, компульсивное, ясно и рационально не мотивированное, не поддающееся контролю побуждение к совершению определенных действий или поступков, конечной целью которых является получение субъективного физического и психологического удовольствия, источником которого могут выступать как психоактивные вещества, так и различные виды деятельности, опредмечивающие аддикцию. Этиологически аддиктивное поведение является результатом взаимодействия множества факторов, представленных на эволюционном, генетическом, нейробиологическом, психофизиологическом, глубинно-, личностно-, социально-психологическом и информационнокультурном уровнях $[1$, с. 8$]$. Как правило, сегодня аддиктивное поведение рассматривается в ряду других форм рискового поведения.

Определенно, культурная и технологическая динамика, к сожалению, несет не только появление положительных социокультурных феноменов, но обусловливает новые 
патологические явления и отклонения в обществе и психологии людей. Очевидная социальная значимость темы возможностей раннего выявления склонностей к аддиктивному поведению определяет объемы и содержание исследований этой темы в научной литературе последних лет.

Поиск литературы за период 20172021 гг. проводился с использованием баз данных РИНЦ, Scopus, Web of Science и Google Scholar. Поисковые запросы включали теги «аддикция», «риск», «вовлечение», «диагностика», «ранняя диагностика», «молодежь», «подростки» (на русском и английском языках), а также делался непосредственный запрос «Единая методика социально-психологического тестирования». Среди предлагаемых источников в ручном режиме отбирались релевантные теме исследования работы. Большинство работ сфокусированы на рисках, связанных с непосредственным употреблением наркотических веществ, а также сконцентрированы на выявлении факторов, провоцирующих начало употребления в реальном времени, и лишь ограниченное число исследований посвящено вопросам раннего выявления склонностей к возникновению такого аддиктивного поведения. Эти немногочисленные работы принадлежат как исследователям из России, так и авторам из США, стран Азии, Латинской Америки и др., что говорит, как о мировом масштабе значимости рассматриваемой проблемы, так и ее сложности и слабой разработанности в научной среде. Наибольший интерес авторов сосредоточен на подборе корректных маркеров, оценка которых позволила бы своевременно обнаружить опасную склонность.

Приведем короткий обзор предлагаемых вариантов маркеров склонностей к немедицинскому употреблению наркотических веществ. А. Н. Яковлев с соавторами предлагает ориентироваться на генетическую предрасположенность в сочетании с результатами оценки по психометрической шкале Клонинджера, оценивающей темперамент и характер (ТCI-125) [2]. Вероятность вовлечения определяется на основании комбинации сочетания таких факторов как «навык самоконтроля», «уверенность и умение говорить «нет»», «навыки принятия решений» и «навыков решения проблем» [3]. В исследовании финских авторов выявляется роль воспринимаемого одиночества в аддиктивном поведении молодежи в межнациональном масштабе [4]. О потенциальном вовлечении говорят такие факторы риска, как плохие отношения с родителями, неадекватный надзор за деятельностью подростков, плохая успеваемость в школах [5]. Установлена связь между неудовлетворенностью своим телом в подростковом возрасте и принятием рискованного поведения в отношении здоровья, в том числе употреблением наркотиков [6].

Среди индикаторов, связанных с состоянием внешней среды выделяются семейные споры и давление со стороны сверстников, которые были наиболее распространенными причинами начала злоупотребления психоактивными веществами среди зависимых участников исследования [7]. Также к внешним условиям, повышающим риски, относится уровень благополучия, оценка которого определяется комбинацией базовых баллов CRAFFT (широко используемого протокола скрининга психоактивных веществ), самоотчета по делинквентному поведению и поведению, нарушающему правила родителей, это обеспечило выработку моделей, которые оказались разными в отношении лиц женского и мужского пола [8], данный аспект выделяют в своей работе наши исследователи О. В. Усова, В. В. Усов, Н. Б. Костина, Т. В. Дуран [9]. Еще 
одно исследование было направлено на объяснение семейных факторов, лежащих в основе развития склонности к злоупотреблению психоактивными веществами у подростков, были выделены группы факторов: отцовская роль, материнская роль, методы дисциплины и семейная функция [10].

Отметим также исследование коллектива авторов во главе с Т. Брумбак, в котором определяются риски и защитные факторы употребления психоактивных веществ у подростков и молодых людей, оценивается взаимосвязь таких факторов, как социальное влияние (например, употребление психоактивных веществ сверстниками), когнитивные особенности (например, ожидания от алкоголя), а также личностные и эмоциональные характеристики (например, импульсивность и типичные реакции на стресс), при этом результаты свидетельствуют о том, что важные для развития аддикции факторы по-разному влияют на употребление психоактивных веществ в подростковом и в юношеском возрасте [11].

Также интерес представляет работа, посвященная анализу рисков употребления психоактивных веществ среди подростков с риском виктимизации в результате пережитого насилия в детстве и влияния наличия/отсутствия у них СДВГ: молодые люди, ставшие жертвами насилия, подвергаются повышенному риску употребления психоактивных веществ в подростковом возрасте, в период, характеризующийся повышенной импульсивностью и рискованным поведением, и этот риск может быть увеличен или уменьшен из-за СДВГ, так девиантная принадлежность к сверстникам была связана с большим риском употребления, а подростки из группы риска с СДВГ могут быть более восприимчивыми к девиантному влиянию сверстников [12]. То же касается и подростков с ПТСР в анамнезе [13].
Отмечается связь между булллингом, виктимизацией и аддиктивным поведением [14]; группа исследователей из Бразилии обнаружила связь показателей депрессии, тревожности и употребления наркотиков среди несовершеннолетних правонарушителей [15].

Отметим отечественное исследование Е. И. Рассказовой с соавторами, в котором показано, что более высокая неудовлетворенность отношениями с родителями, «черно-белое» мышление, антисоциальные тенденции, низкий уровень саморегуляции, высокий уровень рискованного поведения и поиск ощущений у подростков ассоциированы с наркотической зависимостью, однако значение могут иметь и различные социальные ситуации или стратегии реагирования; выявлена высокая значимость саморегуляции [16]. Х. Б. Мосс с соавторами изучил влияние бездомности, патронатной опеки и неблагоприятного опыта детства до 12 класса на развитие трех распространенных аддикций (алкоголь, табак, каннабис) в молодом взрослом возрасте; было выявлено, что опыт бездомности на стадии становления личности может рассматриваться как фактор риска [17]. Сходные аспекты рассматриваются в работе коллектива из Канады, посвященной исследованию аддикций у бездомных подростков [18]. А. М. Моралес с коллегами, авторы лонгитюдного исследования, показывают, что факторы риска в детстве и подростковом возрасте, которые неизменно связывают с повышенным риском зависимости, включают экстернализующие и интернализирующие симптомы, раннее употребление психоактивных веществ и влияние окружающей среды, например поведение родителей и подверженность травматическим переживаниям. Они резюмируют, что этиология расстройств, связанных с употреблением психоактивных веществ, сложна и, вероятно, может 
быть отнесена к множеству причинно-следственных связей, требуется систематическое изучение ассоциаций между факторами риска, чтобы понять неоднозначные результаты в существующей литературе и определить, какие люди должны быть направлены на профилактику [19].

Интересна работа, посвященная оценке реального влияния факторов риска и защитных факторов, предсказывающих злоупотребление рецептурными лекарствами, в выборке пуэрториканских студентов: выяснилось, что лучшими предикторами злоупотребления наркотиками среди пуэрториканских студентов были те, которые связаны с социальным обучением у них дома, за которым следуют поиск ощущений, употребление наркотиков сверстниками, доступность наркотиков и депрессивное настроение. Позитивный взгляд на будущее не был значительным предиктором сокращения злоупотребления лекарствами, отпускаемыми по рецепту, вопреки предположениям [20].

В целом можно сказать, что все авторы подчеркивают сложность ранней диагностики склонности к вовлечению в зависимое поведение, указывают на комплексный (множественный) характер факторов, определяющих риск, отмечают необходимость дальнейшего исследования темы в рамках лонгитюдных проектов. На основании проанализированных источников невозможно составить единый реестр ранних маркеров риска вовлечения в

\footnotetext{
${ }^{1}$ Шарапова А. К., Ефремова Е. В. Результаты социально-психологического исследования на раннее немедицинское употребление психоактивных веществ в Самарской области в 2019 году // Образование и психологическое здоровье: сборник материалов научно-практической конференции (Самара, 13-14 ноября 2019 г.). - Самара: ГБУ ДПО «Региональный социопсихологический центр», 2020. - С. 20-28.
}

наркозависимое поведение, однако, очевидно, что их спектр весьма широк, и они могут различаться в зависимости от возраста, пола, типа наркотического вещества. Отметим, что для указанных исследований характерна логика «факторы риска - факторы защиты», где склонность к вовлечению в употребление наркотических веществ определяется их комбинацией.

ЕМ СПТ, анализируемая в данной статье, является уникальной в своем роде, на сегодняшний день нет других универсальных методик подобного размаха, потому по прямому запросу обнаруживается лишь несколько статей, рассматривающих непосредственно результаты применения ее в регионах $^{1}$. В таких работах можно найти и указания на трудности при работе с методикой, например отмечается, что «в ходе тестирования были определенные трудности при ответах, так как вопросы были непонятны некоторым респондентам, имело двойной смысл и сложное построение. Приходилось объяснять то или иное выражение, что затрудняло процесс выполнения и занимало много времени и в дальнейшем повлияло на показатель резистентности.» [21, с. 192].

В исследовании, непосредственно посвященном проблемам организации методики, указывается, что обучающиеся, находящиеся в зоне риска, нередко отказываются участвовать в тестировании, иногда прямо в процессе

Гайнуллин Р. С., Великанова Л. П., Подосинников С. А., Подосинникова Е. А. Организация и проведение психологического исследования обучающихся различных образовательных организаций, направленного на профилактику девиантного поведения // Новая психология профессионального труда педагога: от нестабильной реальности к устойчивому развитию. - 2021. - C. 200-204. DOI: https://doi.org/10.24412/cl-36422-2021-1-200-204 URL: https://www.elibrary.ru/item.asp?id=46398563 
его прохождения; случаются и запреты на участие в процедуре тестирования со стороны родителей или законных представителей, в результате те, кто нуждается в помощи больше других, ее не получают [22]. Российские исследователи освещают также и вопросы построения программ профилактики на основании результатов методики, например этот аспект освещен в работе О. В. Заевой [23].

Отметим методические пособия, поясняющие, как именно должно организовываться тестирование ${ }^{2}$. В 2020 г. предпринималась попытка модификации методики: «В результате работы над опросником произведено исключение вопросов, не обладающих дифференцирующей способностью по отношению к группе риска, объединение синонимичных шкал, изменение формата обработки и критериев включения учащихся в группу риска, произведен пересмотр статистических границ нормы» [24, p. 67]. Таким образом, обзор литературы позволяет говорить о дискуссионном характере ряда аспектов ЕМ СПТ как на уровне организации процедуры тестирования и последующего алгоритма действий, так и с точки зрения внутренних особенностей - выделенных маркеров, половозрастной ориентации. Все это актуализирует внимательный подход к самой методике и ее результатам и обусловливает необходимость психометрического анализа, который будет способствовать оценке рабочих свойств этого широко применяемого диагностического инструмента.

Цель исследования: выполнить эмпирическую проверку спектра психометрических показателей ЕМ СПТ и выявить проблемные аспекты методики и «зоны риска» ее применения в регионах.

2 Диагностический потенциал социально-психологического тестирования обучающихся: методические рекомендации для педагогов-психологов по резуль-
Исследовательские вопросы:

1. Существуют ли статистически значимые различия в ответах девушек и юношей на вопросы методики?

2. Каковы показатели надежности результатов ЕМ СПТ?

3. Каковы показатели конструктной и дискриминативной валидности ЕМ СПТ?

\section{Методология исследования}

Проводимое в настоящий момент во всех регионах социально-психологическое тестирование направлено на выявление лиц потенциально подверженных вовлечению в немедицинское употребление наркотических веществ. Созданная в России методика раннего выявления склонности к употреблению наркотиков на данный момент является пока единственным доступным инструментом, отвечающим данному запросу. Проведение ЕМ СПТ, разработанной в соответствии с поручением Государственного антинаркотического комитета (протокол от 11 декабря 2017 г. № 35), с 2019/20 учебного года является обязательным для всех образовательных организаций всех субъектов РФ. Цель методики - выявление латентной и явной рискогенности социальнопсихологических условий, лежащих в основе формирования психологической готовности к аддиктивному поведению у подростков и юношей. В основе ЕМ СПТ лежит представление о непрерывности и одновременности воздействия на испытуемых факторов риска и факторов защиты. К факторам риска разработчики ЕМ СПТ отнесли социально-психологические условия, повышающие вероятность вовлечения испытуемых в аддиктивное поведение:

татам проведения социально-психологического тестирования / сост. М. Ю. Михайлина. - Саратов: ГАУ ДПО «СОИРО», 2020. - 32 с. 
склонность к риску, тревожность, подверженность влиянию группы, употребление наркотических средств в социальном окружении и другие. К факторам защиты отнесены: условия среды, повышающие психологическую устойчивость к влиянию факторов риска, принятие родителями и одноклассниками, социальная активность, самоконтроль и самоэффективность. Соотношение данных факторов в результатах испытуемых, по мнению разработчиков, позволяет оценить вероятность вовлечения в аддиктивное поведение. ЕМ СПТ разработана в трех формах: А, В и С, соответственно для трех групп испытуемых: 7-9 классов, 10-11 классов и студентов средних профессиональных образовательных организаций и организаций высшего образования. В данной статье представлены результаты проведенного в июле - сентябре 2021 г. психометрического анализа результатов использования ЕМ СПТ в регионах РФ по «А», «В» и «С». Каждая форма содержит различное число стимульных утверждений и предназначена для различных возрастных групп. Испытуемым предлагается дать ответ по 4-балльной системе оценок («Нет», «Скорее нет, чем да», «Скорее да, чем нет», «Да»). Разработчиками методики предусмотрена система индикаторов недостоверности ответов. ЕМ СПТ относится разработчиками к стандартизированным методикам.

Доступ авторов статьи к исследовательским данным предоставлен в соответствии с государственным заданием № 073-00042-2102 «Научный анализ применения единой методики социально-психологического тестирования обучающихся, направленного на раннее выявление немедицинского потребления наркотических средств и психотропных веществ, и ее доработка». Данные предоставля- лись регионами в виде сводных таблиц, не содержащих персональную информацию об испытуемых.

Критериями первичного отбора данных в выборку для анализа было следующее:

1) отсутствие повреждения данных;

2) качественно и без ошибок обработанные и оформленные данные;

3) возможность при необходимости качественного восполнения данных без искажения результатов с использованием предоставленных заказчиком работающих шаблонов обработки тестовых данных по методике ЕМ СПТ;

4) практическая возможность применения указанного шаблона;

5) наличие в данных сведений о поле и возрасте;

6) данные должны репрезентативно охватывать регионы Российской Федерации, предоставлять сведения о территориально «разбросанных» регионах;

7) данные должны быть собраны с результатов последнего по времени тестирования учащихся в регионе, так как опыт тестирования существенно уменьшает ошибки и искажение данных при их регистрации и обработке.

С помощью этих критериев были отобраны данные, полученные из 7 субъектов РФ. Вниманием оказались охвачены регионы Центральной России, Урала, Севера и Сибири.

Далее при вторичном отборе испытуемых использовались следующие критерии:

1) использование рандомизированного отбора или отсева испытуемых;

2) наличие равного количества испытуемых от каждого региона;

3) наличие равного количества представителей мужского и женского пола в каждом регионе; 
4) наличие не менее 300 человек от каждого региона.
В результате отбора по заданным критериям была сформирована выборка для проведения психометрического анализа (табл. 1).

Таблийа 1

\section{Итоговое количество испытуемых}

Total number of subjects

\begin{tabular}{|l|c|c|c|}
\hline \multicolumn{1}{|c|}{ Форма ЕМ СПТ } & Юноши & Девушки & Всего \\
\hline Форма А & 600 & 600 & 1200 \\
\hline Форма В & 900 & 900 & 1800 \\
\hline Форма С & 1050 & 1050 & 2100 \\
\hline & 2550 & 2550 & 5100 \\
\hline
\end{tabular}

Характер распределения и репрезентативность данных по каждой форме ЕМ СПТ проверялся по всем переменным с применением критерия $\mathrm{D}_{\max }$ Смирнова-Колмогорова, для юношей и девушек раздельно и совместно. Расчеты показали отсутствие нормальности распределения во всех выборках. В связи с чем была сделана проверка гипотез о влиянии на характер распределения таких факторов как пол, возраст, регион. Проверка гипотез осуществлялась методом регрессионной связи указанных факторов со всеми переменными (шкалами и вопросами) ЕМ СПТ по всем ее формам. Проверка репрезентативности проводилась методом расщепления выборок по критерию «первый - второй» на две равные половины с последующим измерением различий по критерию U-Манна-Уитни.

Анализ данных описательной статистики заключался в анализе средних значений, доверительных и процентильных интервалов, дисперсии и стандартного отклонения всех переменных во всех формах методики «ЕМСПТ» с целью определения дифференцирующих способностей стимульного материала и его способности дифференцировать критери- альные события. Расчеты показали необходимость провести сравнительные исследования всех переменных во всех формах методики ЕМ СПТ по критерию пола.

Проверка устойчивости как варианта ретестовой надежности проводилась как корреляция двух половин шкалы итоговых суммарных баллов испытуемых по вопросам методики ЕМ СПТ во всех ее формах и рассчитывалась по формуле Спирмена-Брауна.

Проверка синхронной надежности проводилась с использованием формулы $\alpha$ Кронбаха с использованием суммарных баллов испытуемых по вопросам и шкалам методики ЕМ СПТ во всех ее формах.

С целью проверки конструктной валидности данные по всем вопросам всех форм методики ЕМ СПТ подверглись процедуре факторного анализа - метод главных компонент, вращение Varimax, нижний порог корреляционной значимости переменных $-\mathrm{r} \geq 0,35$, при $\mathrm{p}<0,01$. Помимо дисперсных показателей устойчивости (нижняя граница нормы $51 \%$ ), устойчивость факторов вычислялась по методу Левандовского и была подтверждена для всех факторов во всех матрицах. 
Для определения дискриминативной валидности были отобраны испытуемые с высокими и низкими показателями по итоговым (процентным) шкалам методики, из которых были сформированы соответствующие группы. Итоговые (процентные) показатели этих двух групп сравнивались по критерию Манна-Уитни.

Проверка согласованности итоговых (процентных) показателей и наличия их искажений под влиянием переменных самой методики ЕМ СПТ во всех ее формах проводилась по критерию $\alpha$ - Кронбаха, методом расщепления, а также методами корреляционного, кростабуляционного, регрессионного и дисперсионного анализов.

\section{Результаты исследования}

Проверка репрезентативности методом расщепления выборок по критерию «первый второй» на две равные половины с последующим измерением различий по критерию UМанна-Уитни подтвердила репрезентативность всех выборок.

Было обнаружено, что в результатах диагностики адекватно отражаются естественные возрастные процессы развития для представителей разных полов в различных возрастных группах. Обнаружены статистически значимые различия в результатах между юношами и девушками: по форме «А» - 72 \% переменных, по форме «В»- $71 \%$ переменных, по форме «С»- 57 \% переменных. Наличие различий таких величин диктует необходимость введения мужских и женских стандартизированных норм.

Для формы «А» было обнаружено повышающее влияние фактора возраста $(\beta=0,10$; $\left.\mathrm{B}=0,07 ; \mathrm{R}^{2}=0,02, \mathrm{p}<0,003\right)$ и понижающее влияние фактора региона $(\beta=-0,12 ; \mathrm{B}=-0,11$; $\left.\mathrm{R}^{2}=-0,02, \mathrm{p}<0,00008\right)$ - школьники данной возрастной группы склонны максимизировать свои ответы. Для формы «В» обнаружилось повышающее влияние фактора региона ( $\beta=$ 0,$\left.12 ; \mathrm{B}=0,11 ; \mathrm{R}^{2}=0,02, \mathrm{p}<0,00008\right)$ и понижающее влияние фактора пола ( $\beta=-0,06$; $\left.\mathrm{B}=-0,08 ; \mathrm{R}^{2}=0,02, \mathrm{p}<0,05\right)$. Таким образом, «региональный» фактор искажения оказался связанным с «плавающим коридором нормы» в регионах, снижение фактора пола может быть связано с возрастной спецификой психосоциального развития учащихся. Для формы «С» также обнаружилось повышающее влияние фактора региона $\left(\beta=0,092 ; \mathrm{B}=0,05 ; \mathrm{R}^{2}=\right.$ $0,02, \mathrm{p}<0,00001)$, который также как и для формы «В» связан с «плавающим коридором нормы» в регионах.

Анализ описательной статистики проявил специфические позиции испытуемых в отношении процедуры выполнения методики. Позиция, описываемая коннотацией «Пройти тест как-нибудь, лишь бы отвязались», оказывается довольно устойчивой и распространенной. С такой позицией связан феномен монотонных, необдуманных, «автоматических» ответов или стереотипного, механического нажатия клавиш, фиксирующего те ответы, которые «по умолчанию» предлагает сама машина в процессе тестирования. Для формы «А» такую позицию занимает 28 \% учащихся, для формы «В» -57 \%, для формы «С» $-12 \%$ студентов. Другой позицией является «маскирующий» монотонный выбор отрицательных ответов. Для формы «В» такую позицию занимает $32 \%$ тестирующихся, а для формы «С»$35 \%$, для формы «А» такой позиции не зафиксировано. Наконец, третья специфичная позиция - открытое протестное стремление давать ответы преднамеренно противоположные смыслу стимульных утверждений, зафиксированные у респондентов, заполнявших форму «С». Анализ показал связь такой позиции с реакцией на шкалу «Потребность в одобрении», 
которая одновременно используется для фиксации факта недостоверных ответов $(\beta=0,27$; $\left.\mathrm{B}=0,02 ; \mathrm{R}^{2}=0,07, \mathrm{p}<0,00001\right)$. Протестная позиция «Скажу точно наоборот» связана с реакцией на стимулы именно этой шкалы.
Все формы методики ЕМ СПТ показали достаточно высокие показатели синхронности, внутренней согласованности, устойчивости результатов. ( $\geq 0,86$, см. табл. 2 ).

\section{Показатели надежности методики ЕМ СПТ}

Таблийа 2

Reliability indicators of the UM SPT methodology

\begin{tabular}{|l|c|c|c|}
\hline \multicolumn{1}{|c|}{ Виды надежности } & Форма «А» & Форма «В» & Форма «С» \\
\hline Устойчивость & 0,95 & 0,99 & 0,43 \\
\hline Синхронная & 0,88 & 0,97 & 0,97 \\
\hline$\theta-$ надежность & 0,90 & 0,93 & 0,95 \\
\hline Диапазон с учетом ошибки измерения & $0,89 \div 0,93$ & $0,92 \div 0,98$ & $0,41 \div 0,83$ \\
\hline
\end{tabular}

Все три формы методики (А, В и С) показали высокую степень конструктной валид- ности. Таблица 3 содержит краткое представление факторов в матрицах, выделенных для каждой формы методики.

Тематика и название факторов, выделенных по трем формам методики ЕМ СПТ

Таблий 3

\section{Table 3}

Subject and name of factors identified in three forms of the UM SPT methodology

\begin{tabular}{|c|c|c|c|}
\hline $\begin{array}{c}\text { № } \\
\text { фактора }\end{array}$ & Форма «A» & Форма «B» & Форма «С» \\
\hline 1 & Отношения с родителями & Принятие родителями & $\begin{array}{l}\text { Наркопотребление в соци- } \\
\text { альном окружении и под- } \\
\text { верженность влиянию } \\
\text { группы }\end{array}$ \\
\hline 2 & Стремление к риску & Стремление к риску & $\begin{array}{l}\text { Принятие родителями и од- } \\
\text { ноклассниками }\end{array}$ \\
\hline 3 & $\begin{array}{l}\text { Социальная неприспособ- } \\
\text { ленность }\end{array}$ & Тревожность и фрустрация & Тревожность и фрустрация \\
\hline 4 & Избегание конфликтности & $\begin{array}{l}\text { Наркопотребление в соци- } \\
\text { альном окружении }\end{array}$ & \multirow{4}{*}{$\begin{array}{l}\text { Стремление к риску и нару- } \\
\text { шение норм }\end{array}$} \\
\hline 5 & $\begin{array}{l}\text { Принятие одноклассни- } \\
\text { ками }\end{array}$ & \multirow{3}{*}{$\begin{array}{l}\text { Принятие одноклассниками } \\
\text { и самоэффективность }\end{array}$} & \\
\hline 6 & Просоциальный лидер & & \\
\hline 7 & Соблюдение норм & & \\
\hline & Процент дисперсии - 67 & Процент дисперсии - 60 & Процент дисперсии - 59 \\
\hline
\end{tabular}


При сравнении содержания выделенных структур с базовыми компонентами аддиктивной индивидуальности («самоконтроль поведения», «отношение к нормам», «направленность», «конфликтность», «стратегии преодоления культурного давления», «эмоциональная сфера», «наличие конфликта с социальной средой») [13] обнаруживается содержательное совпадение матриц с содержанием этих компонентов - для формы «А» на 75 \%, для формы «B» и «С» на $86 \%$. То есть методика отражает модель индивидуальности потенциального или реального аддикта, но не модель рисков среды.

При определении дискриминативной валидности было установлено, что все шкалы, кроме шкалы «Самоконтроль поведения» $(\mathrm{U}=147084, \mathrm{Z}=1,04, \mathrm{p}<0,29)$ в форме «A» и шкал «Потребность в одобрении» $(\mathrm{U}=50952$, $\mathrm{Z}=-0,11, \mathrm{p}<0,91)$ и «Социальная активность» $(\mathrm{U}=48501, \mathrm{Z}=1,16, \mathrm{p}<0,25)$ в форме «B», имеют подтвержденную дискриминативную валидность. Форма «С» показала высокий уровень дискриминативной способности по всем шкалам.

Существенные искажения в результаты диагностики вносит не пропорциональное соотношение факторов риска и защиты во всех трех формах методики (см. табл. 4).

Таблица 4

\section{Факторы риска и защиты в методике ЕМ СПТ и их представленность в ее формах}

Table 4

Risk and protection factors in the UM SPT methodology and their representation in its forms

\begin{tabular}{|c|c|c|c|c|c|}
\hline № & Группа & Переменные & $\begin{array}{c}\text { Наличие } \\
\text { в форме } \\
\text { «А» }\end{array}$ & $\begin{array}{c}\text { Наличие } \\
\text { в форме } \\
\text { «В» }\end{array}$ & $\begin{array}{c}\text { Наличие } \\
\text { в форме } \\
\text { «С» }\end{array}$ \\
\hline 1 & \multirow{9}{*}{ 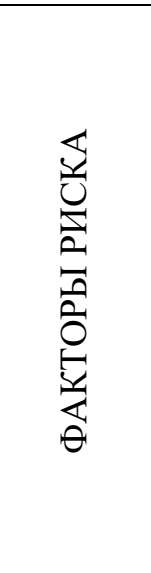 } & Потребность в одобрении 1 & Есть & Есть & Есть \\
\hline 2 & & Потребность в одобрении 2 & Есть & Есть & Есть \\
\hline 3 & & Подверженность влиянию группы & Есть & Есть & Есть \\
\hline 4 & & $\begin{array}{l}\text { Принятие асоциальных установок соци- } \\
\text { ума }\end{array}$ & Есть & Есть & Есть \\
\hline 5 & & Склонность к риску & Есть & Есть & Есть \\
\hline 6 & & Импульсивность & Есть & Есть & Есть \\
\hline 7 & & Тревожность & Есть & Есть & Есть \\
\hline 8 & & Фрустрация & Нет & Есть & Есть \\
\hline 9 & & $\begin{array}{l}\text { Наркопотребление в социальном окруже- } \\
\text { нии }\end{array}$ & Нет & Есть & Есть \\
\hline 1 & \multirow{5}{*}{ 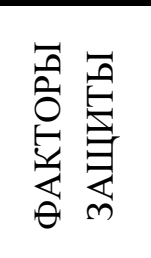 } & Принятие родителями & Есть & Есть & Есть \\
\hline 2 & & Принятие одноклассниками & Есть & Есть & Есть \\
\hline 3 & & Социальная активность & Есть & Есть & Есть \\
\hline 4 & & Самоконтроль поведения & Есть & Есть & Есть \\
\hline 5 & & Самоэффективность & Нет & Есть & Есть \\
\hline
\end{tabular}




\section{Обсуждение}

В результате анализа основных психометрических показателей единой методики социально-психологического тестирования были сделаны следующие выводы.

1. Все формы методики показали достаточно высокие показатели синхронности, внутренней согласованности, устойчивости результатов.

2. Были выявлены факторы искажения результатов методики, связанные с возрастом, полом и регионом проживания испытуемых.

3. Анализ описательной статистики показал достаточно высокий процент монотонных, стереотипных ответов. Позиция респондентов, которую можно обозначить как «Пройти тест как-нибудь, лишь бы отвязались», оказывается довольно устойчивой и распространенной. Данный результат соотносится с выводами, полученными Н. В. Афанасьевой и О. Н. Коптяевой [25]. По мнению А. В. Печеркиной с коллегами, наличие большого количества подобных ответов также может быть связано с эффектом «истощаемости выборки», когда обучающиеся несколько лет подряд проходят тестирование, организованное схожим диагностическим инструментарием, что вызывает у них негативную реакцию [26]. Влияние данного фактора также может быть причиной увеличения количества недостоверных ответов обучающихся при последующем прохождении тестирования, выявленных О. В. Орловой ${ }^{3}$ при анализе результатов проведения ЕМ СПТ. Также увеличение количества недостоверных ответов фиксируется и в исследованиях на студенческой выборке [21].

\footnotetext{
${ }^{3}$ Орлова Л. В. Анализ результатов социально-психологического тестирования учащихся средних и старших классов // Цифровые технологии на службе педагогики и психологии: сборник статей XVII Bсероссийской научно-практической конференции с международным участием, Коломна, 01 января 2021 г. -

Связь между наличием протестных ответов (желание дать намеренно противоположный ответ) зафиксировано у респондентов формы «С» (студентов средних профессиональных образовательных организаций и образовательных организаций высшего образования) и реакцией на шкалу «Потребность в одобрении», которая одновременно используется для фиксации факта недостоверных ответов $\left(\beta=0,27 ; \mathrm{B}=0,02 ; \mathrm{R}^{2}=0,07, \mathrm{p}<0,00001\right)$. Подобный вывод соотносится с результатами исследования, проведенного в ПГНИУ в 2019-2020 гг. [26].

4. При сравнении содержания выделенных структур с базовыми компонентами аддиктивной индивидуальности («самоконтроль поведения», «отношение к нормам», «направленность», «конфликтность», «стратегии преодоления культурного давления», «эмоциональная сфера», «наличие конфликта с социальной средой», описанными в работах А. В. Смирнова [1; 13]) обнаруживается содержательное совпадение матриц с содержанием этих компонентов. Таким образом, методика отражает модель индивидуальности личности с потенциальным или реальным аддиктивным поведением.

5. Существенные искажения в результаты диагностики вносит непропорциональное соотношение факторов риска и защиты во всех трех формах методики.

Опираясь на сделанные в ходе исследования выводы, авторы выделили следующие зоны риска, дефициты и возможные варианты их минимизации.

Коломна: Государственное образовательное учреждение высшего образования Московской области «Государственный социально-гуманитарный университет». - 2021. - C. 170-174. URL: https://elibrary.ru/item.asp?id=45575998 


\section{1. Прочедура тестирования.}

Выявлено: возрастная специфика обучающихся в ответах на утверждения; низкая мотивация обучающихся к участию в тестировании; максимизация ответов, протестная позиция в ответах, монотонные, «автоматические» и необдуманные ответы; внесение искажений в результаты тестирования шкалами выявления недостоверных ответов внутри самой методики.

Предложения по доработке: разработка подробных методических рекомендаций по проведению тестирования; изменение принципов и технических решений для выявления респондентов с недостоверными ответами с учетом возрастной специфики и доработка контроля монотонии, «автоматизма» ответов, «не включенной» позиции респондентов (например, возврат к началу тестирования).

2. Содержание методики.

Выявлено: нарушение соотношения факторов риска и факторов защиты во всех формах методики; как следствие, выводимые факторные квотиенты заведомо склоняются в сторону увеличения показателей факторов риска, что также увеличивает итоговые показатели вероятности вовлечения в аддиктивное поведение.

Предложения по доработке: осуществить выравнивание количества факторов риска и факторов защиты путем введения поправочных коэффициентов или иных уравновешивающих факторы процедурах [27].

\section{3. Интерпретация результатов.}

Выявлено: узкий диапазон вариативности ответов респондентов по предлагаемой номинативной шкале ответов не позволяет достоверно установить количественно-качественный критерий перехода от нормативных психологических явлений к аддиктивным проявлениям.
Направления совершенствования ЕМ СПТ: замена узкой номинативной шкалы вариантов ответов на порядковую (от 1 до 10 баллов); разработка единых нормативных показатели через перевод накопленных баллов в Т-баллы/стены/др. по критерию пола и возраста для всех форм методики с использованием репрезентативных выборок стандартизации, обладающих нормальностью распределения данных, равным количеством представителей мужского и женского пола; замена варианта подсчета региональных норм с применением стандартного отклонения на доверительные интервалы с использованием выборки стандартизации.

\section{Заключение}

Анализ литературы показал, что большинство исследователей подчеркивают сложность ранней диагностики склонности к вовлечению в зависимое поведение, указывают на комплексный (множественный) характер факторов, определяющих риск. Отмечается невозможность составления однозначного единого реестра маркеров раннего риска, при этом авторы указывают, что их спектр весьма широк, и они могут различаться в зависимости от возраста, пола, типа психоактивного вещества или деятельности. Авторы пришли к оценке степени риска на основе рассмотрения соотношения «факторов риска - факторов защиты» (или наоборот), где вероятность аддиктивного поведения определяется именно их соотношением. ЕМ СПТ, анализируемая в данной статье, отражает именно такой подход. Уникальность ЕМ СПТ определяется первенством применения в отношении школьной страты населения и примером эмпирического воплощения инструмента диагностики социокультурных рисков, лежащих в основе формирования психологической готовности к аддиктивному поведению у подростков и юношей. 
Авторами выполнена эмпирическая проверка основных психометрических показателей ЕМ СПТ. Обнаружены статистически значимые различия в ответах девушек и юношей, что говорит о необходимости введения стандартизированных норм для женской и мужской выборок отдельно. Выявлено влияние факторов пола, возраста и региона на результаты методики. Анализ данных показал, что все формы методики имеют высокую степень синхронности, внутренней согласованности и устойчивости результатов, а также конструктной валидности. Факторный анализ показал содержательное наполнение методики базовыми компонентами аддиктивной индивидуальности. Расчеты дискриминативной валидности показали, что большинство шкал методики имеет высокий уровень данного вида валидности (кроме шкал «Самоконтроль поведения» формы «А» и «Потребность в одобрении» и «Социальная активность» формы «В»). Анализ содержания вопросов методики указывает на доминирование стимульного материала, относящегося к факторам риска над факторами защиты (9 к 5), что вносит определенные искажения в результаты диагностики.

Теоретический и практический вклад выполненного исследования определяется описанием результатов эмпирической проверки спектра психометрических показателей методики ЕМ СПТ, проведенной на основе данных, полученных из регионов страны в ходе массового тестирования школьников и студентов. Эмпирически и с помощью математико-статистических методов обнаружены проблемные зоны применения методики ЕМ СПТ в регионах, обозначены возможные варианты доработки методики. Укажем, что психометрическая проверка проводилась в отношении всех трех форм методики ЕМ СПТ (формы «A», «В»и «С»).

Доступ авторов статьи к исследовательским данным предоставлен в соответствии с государственным заданием №073-00042-2102. Информация предоставлялась регионами в виде сводных таблиц, не содержащих персональных данных испытуемых.

Представленное в статье исследование имеет ряд ограничений, например, связанных со сложностью процедуры оценки содержательной валидности методики. Это показывает актуальность дальнейшего исследования проблемы социально-психологического тестирования несовершеннолетних, а также побуждает к выполнению проверки понятности содержания стимульного материала для различных возрастных групп. Представляется перспективным задача приближения семантики стимульного материала к современной школьной и студенческой среде.

\section{СПИСОК ЛИТЕРАТУРЫ}

1. Смирнов А. В. Психосексуальные пропорции маскулинности-феминности и социальностиасоциальности поведения у аддиктов // Наркология. - 2015. - Т. 14, № 4. - С. 83-89. URL: https://elibrary.ru/item.asp?id=24170049

2. Яковлев А. Н., Пашкевич Н. В., Пажитных Д. В., Ткачев А. А., Бродянский В. М., Чупрова Н. А., Щурина А. В., Ромашкин Р. А., Витчинкина В. И. Поиск генетических и психологических маркеров риска потребления наркотиков подростками с аддиктивным поведением в рамках первичной профилактики: предварительные результаты пилотного исследования в Липецке // Сибирский вестник психиатрии и наркологии. - 2017. - № 2. - С. 5-11. URL: https://www.elibrary.ru/item.asp?id=29432399 
3. Sotoudeh H. G., Nazari M. A., Mirhashemi M. A Social-cognitive educational protocol for parents with adolescents at risk of substance use: Impact on adolescents' life skill // Iranian Journal of Psychiatry. - 2021. - Vol. 16 (3). - P. 295-304. DOI: https://doi.org/10.18502/ijps.v16i3.6255

4. Savolainen I., Oksanen A., Kaakinen M., Sirola A., Paek H.-J. The Role of Perceived Loneliness in Youth Addictive Behaviors: Cross-National Survey Study // JMIR Mental Health. - 2020. Vol. 7 (1). - P. e 14035. DOI: https://doi.org/10.2196/14035

5. Sai Sandhya T., Lakshmi, T., Rajeshkumar S., Roy A., Gurunathan D., Geetha R. V., Pradeep Kumar R. Knowledge, awareness and practice regarding drug abuse among teenagers between the age group of 14-19 years: A questionnaire survey // Indian Journal of Public Health Research and Development. - 2019. - Vol. 10 (11). - P. 3536-3539. DOI: https://doi.org/10.5958\%2f0976-5506

6. Bornioli A., Lewis-Smith H., Smith A., Slater A., Bray I. Adolescent body dissatisfaction and disordered eating: Predictors of later risky health behaviours // Social Science and Medicine. - 2019. Vol. 238. - P. 112458. DOI: https://doi.org/10.1016/j.socscimed.2019.112458

7. Ghazal P. Rising trend of substance abuse in Pakistan: a study of sociodemographic profiles of patients admitted to rehabilitation centres // Public Health. - 2019. - Vol. 167. - P. 34-37. DOI: https://doi.org/10.1016/j.puhe.2018.10.020

8. Menon S. V., Thakur H., Shorey R. C., Cohen J. R. Predicting Adolescent Substance Use in a Child Welfare Sample: A Multi-Indicator Algorithm // Assessment. - 2021. - Vol. 28 (4). - P. 12071218. DOI: https://doi.org/10.1177/1073191119880966

9. Усова О. В., Усов В. В., Костина Н. Б., Дуран Т. В. Девиантное поведение подростков как проявление индивидуальной аномии: социальный и гендерный аспекты проблемы // Образование и наука. - 2021. - Т. 23, № 5. - C. 164-192. DOI: https://doi.org/10.17853/1994-56392021-5-164-192 URL: https://www.elibrary.ru/item.asp?id=45789240

10. Moradi P., Lavasani F. F., Dejman M. Adolescent substance abuse and family environment: A qualitative study // International Journal of High Risk Behaviors and Addiction. - 2019. Vol. 8 (2). - P. e83781. DOI: https://doi.org/10.5812/ijhrba.83781

11. Brumback T., Thompson W., Cummins K., Brown S., Tapert S. Psychosocial predictors of substance use in adolescents and young adults: Longitudinal risk and protective factors // Addictive Behaviors. - 2021. - Vol. 121. - P. 106985. DOI: https://doi.org/10.1016/j.addbeh.2021.106985

12. García B. H., Vázquez A. L., Moses J. O., Cromer K. D., Morrow A. S., Villodas M. T. Risk for substance use among adolescents at-risk for childhood victimization: The moderating role of ADHD // Child Abuse and Neglect. - 2021. - Vol. 114. - P. e104977. DOI: https://doi.org/10.1016/j.chiabu.2021.104977

13. Смирнов А. В. Психология аддиктивного поведения. - Екатеринбург: Урал. гос. пед. ун-т, 2014. - 379 c. ISBN: 978-5-7186-0605-8 URL: https://www.elibrary.ru/item.asp?id=23628115

14. Richard J., Grande-Gosende A., Fletcher E., Temcheff C. E., Ivoska W., Derevensky J. L. Externalizing Problems and Mental Health Symptoms Mediate the Relationship Between Bullying Victimization and Addictive Behaviors // International Journal of Mental Health and Addiction. 2020. - Vol. 18 (4). - P. 1081-1096. DOI: https://doi.org/10.1007/s11469-019-00112-2

15. da Silva M. C., Cruz A. P. M., Teixeira M. O. Depression, anxiety, and drug usage history indicators among institutionalized juvenile offenders of Brasilia // Psicologia-Reflexao e Critica. 2021. - Vol. 34 (1). - P. e17. DOI: https://doi.org/10.1186/s41155-021-00184-x

16. Rasskazova E. I., Tkhostov A. S., Falkovskaia L. P., Kiseleva A. L., Kremlev A. F., Artamonova E. G. Psychological indicators of delinquent behavior in adolescents: The potential of the 'psychological risk factors of deviant behavior in adolescents inventory' for differentiating between adolescents with delinquent behavior, drug addiction, and controls // Psychology in Russia: State of 
the Art. - 2019. - Vol. 12 (3). - P. 149-162. DOI: https://doi.org/10.11621/pir.2019.0311 URL: https://www.elibrary.ru/item.asp?id=42629811

17. Moss H. B., Ge S., Trager E., Saavedra M., Yau M., Ijeaku I., Deas D. Risk for Substance Use Disorders in young adulthood: Associations with developmental experiences of homelessness, foster care, and adverse childhood experiences // Comprehensive Psychiatry. - 2020. - Vol. 100. P. 152175. DOI: https://doi.org/10.1016/j.comppsych.2020.152175

18. Kidd S. A., Gaetz S., O'Grady B., Schwan K., Zhao H., Lopes K., Wang W. The Second National Canadian Homeless Youth Survey: Mental Health and Addiction Findings: La Deuxieme Enquete Nationale Aupres des Jeunes Sans Abri : Resultats en Matiere De Sante Mentale et de Toxicomanie // Canadian journal of psychiatry-revue canadienne de psychiatrie. - 2021. Vol. 66 (10). - P. 897-905. DOI: https://doi.org/10.1177/0706743721990310

19. Morales A. M., Jones S. A., Kliamovich D., Harman G., Nagel B. J. Identifying Early Risk Factors for Addiction Later in Life: a Review of Prospective Longitudinal Studies // Current Addiction Reports. - 2020. - Vol. 7 (1). - P. 89-98. DOI: https://doi.org/10.1007/s40429-019-00282-y

20. Rivera-Rios M. N., Cabiya J. J., Sanchez-Cardona I. Risk and protective factors predicting prescription drug misuse in a sample of Puerto Rican students // Journal of addictive diseases. 2021. - Vol. 5. DOI: https://doi.org/10.1080/10550887.2021.1930825

21. Стрелкова О. В. Выявление склонности первокурсников к вовлечению в употребление психоактивных веществ с помощью социально-психологического тестирования // Известия Балтийской государственной академии рыбопромыслового флота: психолого-педагогические науки. - 2021. - № 2. - C. 189-192. DOI: https://doi.org/10.46845/2071-5331-2021-2-56-189192 URL: https://www.elibrary.ru/item.asp?id=46182590

22. Каснова М. С. Проблема реализации мер раннего выявления незаконного потребления наркотических средств и психотропных веществ в общеобразовательной среде // Вестник Краснодарского университета МВД России. - 2019. - № 3. - С. 24-28. URL: https://www.elibrary.ru/item.asp?id=41108917

23. Заева О. В. Использование результатов единой методики социально-психологического тестирования для организации профилактической работы с обучающимися образовательной организации // Образование личности. - 2020. - № 3-4. - С. 111-141. URL: https://www.elibrary.ru/item.asp?id=44837298

24. Гилемханова Э. Н., Васина В. В., Герасимова В. В. Модификация инструментария диагностики психологических рисков наркотизации школьников // Мир науки. Педагогика и психология. -2020 . - Т. 8. № 5. - C. 67. URL: https://www.elibrary.ru/item.asp?id=44576890

25. Афанасьева Н. В., Коптяева О. Н. Социально-психологическое тестирование как инструмент системной профилактической работы // Источник. - 2020. - № 1. - С. 13-15. URL: https://elibrary.ru/item.asp?id=42969995

26. Печеркина А. В., Жданова С. Ю., Зарипова Л. З. Проблемы организации социально-психологического тестирования обучающихся в условиях высшего учебного заведения // Социальные и гуманитарные науки: теория и практика. - 2020. - № 1. - С. 395-402. URL: https://elibrary.ru/item.asp?id=44460887

27. Батурин Н. А. Технология разработки психодиагностических методик. - Челябинск: ЮжноУральский государственный университет (национальный исследовательский университет), 2012. - 135 c. ISBN: 978-5-696-04216-9 URL: https://www.elibrary.ru/item.asp?id=20115765

Поступила: 29 Ноября 2021 Принята: 10 января 2022 Опубликована: 28 февраля 2022 


\section{Заявленный вклад авторов:}

Смирнов Александр Васильевич: сбор эмпирического материала, выполнение статистических процедур.

Симонова Ирина Александровна: сбор материалов, литературный обзор.

Попп Иван Александрович: сбор материалов, оформление текста статьи.

Максимова Людмила Александровна: организация исследования, интерпретация результатов и написание разделов статьи «Введение», «Результаты».

\section{Информация о конфликте интересов:}

Авторы заявляют об отсутствии конфликта интересов.

\section{Смирнов Александр Васильевич}

\section{Информация об авторах}

доктор психологических наук, профессор, кафедра общей психологии и конфликтологии, Уральский государственный педагогический университет, пр. Космонавтов, 26, 620017, Екатеринбург, Россия.

ORCID ID: http://orcid.org/0000-0003-1777-139x

E-mail: k-66756@planet-a.ru

\section{Симонова Ирина Александровна}

кандидат философских наук, доцент, кафедра педагогики и педагогической компаративистики, Уральский государственный педагогический университет, пр. Космонавтов, 26, 620017, Екатеринбург, Россия. кафедра социальной философии, Уральский федеральный университет имени первого Президента России Б. Н. Ельцина, ул. Мира, д. 19, 620002, г. Екатеринбург, Россия.

ORCID ID: http://orcid.org/0000-0001-8669-6376

E-mail: luboe05@mail.ru

\section{Попп Иван Александрович}

кандидат исторических наук, доцент, кафедра педагогики и педагогической компаративистики, Уральский государственный педагогический университет, пр. Космонавтов, 26, 620017, Екатеринбург, Россия.

ORCID ID: http://orcid.org/0000-0002-5257-1126

E-mail: popp82@mail.ru

\section{Максимова Людмила Александровна}

кандидат педагогических наук, директор, институт психологии, Уральский государственный педагогический университет, пр. Космонавтов, 26, 620017, Екатеринбург, Россия.

ORCID ID: https://orcid.org/0000-0003-0017-5321

E-mail: maximova70@mail.ru 


\title{
A unified methodology for psycho-social assessment of minors: A psychometric analysis of the results
}

\author{
Aleksandr V. Smirnov ${ }^{1}$, Irina A. Simonova ${ }^{1,2}$, Ivan A. Popp ${ }^{1}$, Lyudmila A. Maksimova $\square^{1}$ \\ ${ }^{1}$ Ural State Pedagogical University, Ekaterinburg, Russian Federation \\ ${ }^{2}$ Ural Federal University named after the 1st President of Russia B.N. Yeltsin, Ekaterinburg, Russian \\ Federation
}

\begin{abstract}
Introduction. The relevance of this study is determined, on the one hand, by the need for prevention and early identification of deviant behaviors among minors against the background of the growth of epidemiology and forms of addictive behaviors among other forms of risk behaviors of schoolchildren and students, on the other hand, by the lack of appropriate diagnostic tools that have been validated by the appropriate psychometric procedures.

Currently, in the Russian Federation, a unified method of socio-psychological assessment of minors (hereinafter 'UM-SPT') is being massively implemented. It is aimed at identifying the latent and obvious risks within socio-psychological conditions that determine psychological readiness for addictive behaviors in adolescents and young people. The aim of this study was to conduct an empirical analysis of the psychometric indicators within "UM-SPT" (e.g. reliability, validity, discriminativeness) in order to reveal the limitations of the methodology and its application in the regions.

Materials and Methods. The data were processed using parametric and nonparametric criteria for communication, differences, consistency (Pearson, Student, Kolmogorov-Smirnov, Mann-Whitney, Fisher, Cronbach, and Spearman). Various types of statistical data analysis (correlation, regression, variance, factor) were used. Statistical data processing was carried out both manually and using the Statistica software package. The research was conducted in different regions of the Russian Federation. The sample consisted of 5100 people.

Results. The authors found that all three forms of the technique have high indicators of synchronicity, internal consistency, and stability of the results. On the other hand, the study revealed
\end{abstract}

\section{Acknowledgments}

The study was financially supported by the Ministry of Education of the Russian Federation by a state assignment. Project No. 073-00042-21-02 ("Scientific analysis of the application of a unified methodology of social and psychological testing of students, aimed at early detection of non-medical consumption of narcotic drugs and psychotropic substances, and its refinement").

\section{For citation}

Smirnov A. V., Simonova I. A., Popp I. A., Maksimova L. A. A unified methodology for psycho-social assessment of minors: A psychometric analysis of the results. Science for Education Today, 2022, vol. 12 (1), pp. 7-28. DOI: http://dx.doi.org/10.15293/2658-6762.2201.01

曰 Corresponding Author: Lyudmila A. Maksimova, maximova70@mail.ru

(C) Aleksandr V. Smirnov, Irina A. Simonova, Ivan A. Popp, Lyudmila A. Maksimova, 2022 


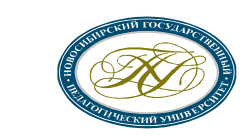

Science for Education Today

2022, vol. 12, issue 1 http://en.sciforedu.ru/

ISSN 2658-6762

factors of result distortion associated with the age, gender and region of residence of the subjects. An analysis of descriptive statistics showed a fairly high percentage of monotonous and stereotyped responses. When comparing the results of factor analysis with the content of the basic components of an addictive personality ('self-control of behavior', 'attitude to norms', 'focus', 'conflict', 'strategies for overcoming cultural pressure', 'emotional sphere', 'a conflict with the social environment'), ameaningful coincidence of the factor structure with the content of these components was found. A disproportionate ratio of risk and protection factors in all three forms of the technique introduces significant distortions in the diagnostic results.

Conclusions. The authors revealed and described the limitations of the methodology and risk areas of its application in the regions. The main indicators of reliability, validity, discriminativeness were identified on representative samples. Recommendations for improving the inventory were proposed.

\section{Keywords}

Risky behavior of schoolchildren and students; Unified methodology of socio-psychological assessment; Risk factors; Protection factors; Early diagnosis.

\section{REFERENCES}

1. Smirnov A. V. Psychosexual proportions of masculinity-femininity, social and asocial behavior in addicts. Narcology, 2015, vol. 14 (4), pp. 83-89. (In Russian) URL: https://www.elibrary.ru/item.asp?id=24170049

2. Yakovlev A. N., Pashkevich N. V., Pazhitnykh D. V., Tkachev A. A., Brodyansky V. M., Chuprova N. A., Churina A. V., Romashkin R. A., Vetchinkina V. I. The search for genetic and psychological markers of the risk of drug use by adolescents with addictive behavior as part of primary prevention: preliminary results of a pilot study in Lipetsk. Siberian Bulletin of Psychiatry and Narcology, 2017, vol. 95 (2), pp. 5-11. (In Russian) URL: https://www.elibrary.ru/item.asp?id=29432399

3. Sotoudeh H. G., Nazari M. A., Mirhashemi M. A Social-cognitive educational protocol for parents with adolescents at risk of substance use: Impact on adolescents' life skill. Iranian Journal of Psychiatry, 2021, vol. 16 (3), pp. 295-304. DOI: https://doi.org/10.18502/ijps.v16i3.6255

4. Savolainen I., Oksanen A., Kaakinen M., Sirola A., Paek H.-J. The Role of Perceived Loneliness in Youth Addictive Behaviors: Cross-National Survey Study. JMIR Mental Health, 2020, vol. 7 (1), pp. 14035. DOI: https://doi.org/10.2196/14035

5. Sai Sandhya T., Lakshmi, T., Rajeshkumar S., Roy A., Gurunathan D., Geetha R. V., Pradeep Kumar R. Knowledge, awareness and practice regarding drug abuse among teenagers between the age group of 14-19 years: A questionnaire survey. Indian Journal of Public Health Research and Development, 2019, vol. 10 (11), pp. 3536-3539. DOI: https://doi.org/10.5958/0976-5506

6. Bornioli A., Lewis-Smith H., Smith A., Slater A., Bray I. Adolescent body dissatisfaction and disordered eating: Predictors of later risky health behaviours. Social Science and Medicine, 2019, vol. 238, pp. 112458. DOI: https://doi.org/10.1016/j.socscimed.2019.112458

7. Ghazal P. Rising trend of substance abuse in Pakistan: a study of sociodemographic profiles of patients admitted to rehabilitation centres. Public Health, 2019, vol. 167, pp. 34-37. DOI: https://doi.org/10.1016/j.puhe.2018.10.020

8. Menon S. V., Thakur H., Shorey R. C., Cohen J. R. Predicting Adolescent Substance Use in a Child Welfare Sample: A Multi-Indicator Algorithm. Assessment, 2021, vol. 28 (4), pp. 1207-1218. DOI: https://doi.org/10.1177/1073191119880966 


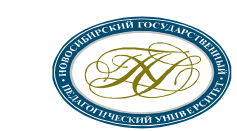

Science for Education Today

2022, vol. 12, issue 1 http://en.sciforedu.ru/

ISSN 2658-6762

9. Usova O. V., Usov V. V., Kostina N. B., Duran T. V. Deviant behaviour of adolescents as a manifestation of individual anomie: social and gender aspects of the problem. The Education and Science Journal, 2021, vol. 23 (5), pp. 164-192. (In Russian) DOI: https://doi.org/10.17853/19945639-2021-5-164-192 URL: https://www.elibrary.ru/item.asp?id=45789240

10. Moradi P., Lavasani F. F., Dejman M. Adolescent substance abuse and family environment: A qualitative study. International Journal of High Risk Behaviors and Addiction, 2019, vol. 8 (2), pp. e83781. DOI: https://doi.org/10.5812/ijhrba.83781

11. Brumback T., Thompson W., Cummins K., Brown S., Tapert S. Psychosocial predictors of substance use in adolescents and young adults: Longitudinal risk and protective factors. Addictive Behaviors, 2021, vol. 121, pp. 106985. DOI: https://doi.org/10.1016/j.addbeh.2021.106985

12. García B. H., Vázquez A. L., Moses J. O., Cromer K. D., Morrow A. S., Villodas M. T. Risk for substance use among adolescents at-risk for childhood victimization: The moderating role of ADHD. Child Abuse and Neglect, 2021, vol. 114, pp. 104977. DOI: https://doi.org/10.1016/j.chiabu.2021.104977

13. Smirnov A. V. Psychology of Addictive Behavior. Ekaterinburg: Ural State Pedagogical University, 2014. 379 p. (In Russian) ISBN: 978-5-7186-0605-8 URL: https://www.elibrary.ru/item.asp?id=23628115

14. Richard J., Grande-Gosende A., Fletcher E., Temcheff C. E., Ivoska W., Derevensky J. L. Externalizing Problems and Mental Health Symptoms Mediate the Relationship Between Bullying Victimization and Addictive Behaviors. International Journal of Mental Health and Addiction, 2020, vol. 18 (4), pp. 1081-1096. DOI: https://doi.org/10.1007/s11469-019-00112-2

15. da Silva M. C., Cruz A. P. M., Teixeira M. O. Depression, anxiety, and drug usage history indicators among institutionalized juvenile offenders of Brasilia. Psicologia-reflexao e critica, 2021, vol. 34 (1), pp. e17. DOI: https://doi.org/10.1186/s41155-021-00184-x

16. Rasskazova E. I., Tkhostov A. S., Falkovskaia L. P., Kiseleva A. L., Kremlev A. F., Artamonova E. G. Psychological indicators of delinquent behavior in adolescents: The potential of the 'psychological risk factors of deviant behavior in adolescents inventory' for differentiating between adolescents with delinquent behavior, drug addiction, and controls // Psychology in Russia: State of the Art, 2019, vol. 12 (3), pp. 149-162. DOI: https://doi.org/10.11621/pir.2019.0311 URL: https://www.elibrary.ru/item.asp?id=42629811

17. Moss H. B., Ge S., Trager E., Saavedra M., Yau M., Ijeaku I., Deas D. Risk for Substance Use Disorders in young adulthood: Associations with developmental experiences of homelessness, foster care, and adverse childhood experiences. Comprehensive Psychiatry, 2020, vol. 100, pp. 152175. DOI: https://doi.org/10.1016/j.comppsych.2020.152175

18. Kidd S. A., Gaetz S., O'Grady B., Schwan K., Zhao H., Lopes K., Wang W. The Second National Canadian Homeless Youth Survey: Mental Health and Addiction Findings: La Deuxieme Enquete Nationale Aupres des Jeunes Sans Abri : Resultats en Matiere De Sante Mentale et de Toxicomanie. Canadian Journal of Psychiatry-Revue Canadienne de Psychiatrie, 2021, vol. 66 (10), pp. 897905. DOI: https://doi.org/10.1177/0706743721990310

19. Morales A. M., Jones S. A., Kliamovich D., Harman G., Nagel B. J. Identifying Early Risk Factors for Addiction Later in Life: a Review of Prospective Longitudinal Studies. Current Addiction Reports, 2020, vol. 7 (1), pp. 89-98. DOI: https://doi.org/10.1007/s40429-019-00282-y

20. Rivera-Rios M. N., Cabiya J. J., Sanchez-Cardona I. Risk and protective factors predicting prescription drug misuse in a sample of Puerto Rican students. Journal of Addictive Diseases, 2021, vol. 5. DOI: https://doi.org/10.1080/10550887.2021.1930825 


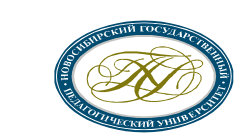

Science for Education Today

2022, vol. 12, issue 1 http://en.sciforedu.ru/

ISSN 2658-6762

21. Strelkova O. V. Identification of the tendency of first-year students to be involved in psychoactive substances using social and psychological testing. News of the Baltic State Academy of Fishing Fleet: Psychological and Pedagogical Sciences, 2021, no. 2, pp. 189-192. (In Russian) DOI: https://doi.org/10.46845/2071-5331-2021-2-56-189-192

URL: https://www.elibrary.ru/item.asp?id=46182590

22. Kasnova M. S. The problem of implementing measures for the early detection of illicit consumption of narcotic drugs and psychotropic substances in the general educational environment. Bulletin of the Krasnodar University of the Ministry of Internal Affairs of Russia, 2019, no. 3, pp. 24-28. (In Russian) URL: https://www.elibrary.ru/item.asp?id=41108917

23. Zaeva O. V. The use of the results of a unified social and psychological testing technique for organization of preventive work with students of an educational organization. Personal Education, 2020, no. 3-4, pp. 111-141. (In Russian) URL: https://www.elibrary.ru/item.asp?id=44837298

24. Gilemhanova E. N., Vasina V. V., Gerasimova V. V. Modification of instrumentation of diagnostics of psychological risks of narcotic drug schoolchildren. The World of Science. Pedagogy and Psychology, 2020, vol. 8 (5), pp. 67-70. (In Russian) URL: https://www.elibrary.ru/item.asp?id=44576890

25. Afanas'eva N. V., Koptyaeva O. N. Social-psychological testing as a tool for system preventive work. Source, 2020, no. 1, pp. 13-15. (In Russian) URL: https://elibrary.ru/item.asp?id=42969995

26. Pecherkina A. V., Zhdanova S. Yu., Zaripova L. Z. Problems of students' socio-psychological testing in higher education institutions. Social and Humanitarian Sciences: Theory and Practice, 2020, no. 1, pp. 395-402. (In Russian) URL: https://elibrary.ru/item.asp?id=44460887

27. Baturin N. A. Technology for the development of psychodiagnostic methods. Chelyabinsk: South Ural State University (National Research University), 2012. 135 p. (In Russian) ISBN: 978-5-69604216-9 URL: https://www.elibrary.ru/item.asp?id=20115765

Submitted: 29 November 2021 Accepted: 10 January 2022 Published: 28 February 2022

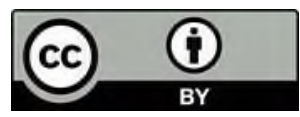

This is an open access article distributed under the Creative Commons Attribution License which permits unrestricted use, distribution, and reproduction in any medium, provided the original work is properly cited. (CC BY 4.0).

\section{The authors' stated contribution:}

Alexandr Vasilyevich Smirnov

Contribution of the co-author: collection of empirical material, implementation of statistical procedures.

Irina Aleksandrovna Simonova

Contribution of the co-author: literary review.

Ivan Aleksandrovich Popp

Contribution of the co-author: design of the text of the article.

Lyudmila Aleksandrovna Maksimova

Contribution of the co-author: organization of the study, interpretation of the results and writing sections of the article "Introduction", "Results". 


\section{Information about competitive interests:}

The authors claim that they do not have competitive interests.

\section{Information about the Authors}

\section{Aleksandr Vasilevich Smirnov}

Doctor of Psychology, Professor,

Department of General Psychology and Conflictology,

Ural State Pedagogical University;

Kosmonavtov Ave., 26, 620017, Ekaterinburg, Russian Federation.

Researcher ID: ABC-4987-2021

ORCID ID: http://orcid.org/0000-0003-1777-139x

E-mail: k-66756@planet-a.ru

\section{Irina Aleksandrovna Simonova}

Candidate of Philosophical Sciences, Associate Professor

Department of Pedagogy and Pedagogical Comparative Studies,

Ural State Pedagogical University,

Kosmonavtov Ave., 26, 620017, Ekaterinburg, Russian Federation.

Associate Professor

Department of Social philosophy,

Ural Federal University named after the 1st President of Russia B.N. Yeltsin,

Mira str., 19, 620002, Ekaterinburg, Russian Federation.

Researcher ID: O-1162-2016

ORCID ID: https://orcid.org/0000-0001-8669-6376

E-mail: luboe05@mail.ru

\section{Ivan Aleksandrovich Popp}

Candidate of Historical Sciences, Associate Professor

Department of Pedagogy and Pedagogical Comparative Studies,

Ural State Pedagogical University,

Kosmonavtov Ave., 26, 620017, Ekaterinburg, Russian Federation.

Researcher ID: E-7729-2017

ORCID ID: https://orcid.org/0000-0002-5257-1126

E-mail: popp82@mail.ru

\section{Lyudmila Aleksandrovna Maksimova}

Candidate of Pedagogical Sciences, Director

Institute of Psychology,

Ural State Pedagogical University,

Kosmonavtov Ave., 26, 620017, Yekaterinburg, Russian Federation.

Scopus ID: 38261746300

Reseacher ID: ABB-3985-2020

ORCID ID: https://orcid.org/0000-0003-0017-5321

E-mail: maximova70@mail.ru 


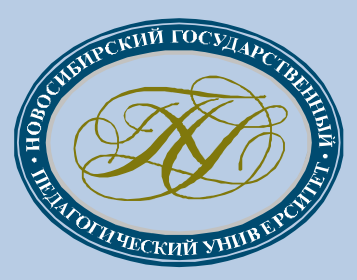

www.sciforedu.ru

\author{
ФИЛОСОФИЯ \\ И ИСТОРИЯ \\ ДЛЯ ОБРАЗОВАНИЯ
}

\title{
PHILOSOPHY AND HISTORY \\ FOR EDUCATION
}




\title{
The collapse of neoliberal concept of education in the COVID-19 era and the prospects for post-COVID education
}

\author{
Madina S. Ashilova $^{1}$, Alibek S. Begalinov ${ }^{2}$, Kalimash K. Begalinova ${ }^{3}$ \\ ${ }^{1}$ Abylai Khan Kazakh University of International Relations and World Languages, \\ Almaty, Republic of Kazakhstan \\ ${ }^{2}$ International University of Information Technologies, Almaty, Republic of Kazakhstan \\ ${ }^{3}$ Al-Farabi Kazakh National University, Almaty, Republic of Kazakhstan
}

\begin{abstract}
Introduction. The authors investigate the problem of value changes occurring in the higher education system. The COVID-19 pandemic, which spread around the world in early 2020, has had a serious impact on higher education. It has led to the need to revise the axiological foundations of modern education. The purpose of this article is to analyze the neoliberal concept of higher education in the modern world and identify trends for the future post-COVID education.

Materials and Methods. The materials included international research articles published between 2020 and 2021 and devoted to the subject under study, as well as a sociological study conducted in the Republic of Kazakhstan and investigating well-being and value orientations of students during the COVID-19 pandemic. A sample of 1,000 university students from all 14 regions in Kazakhstan was interviewed. The main proportion of students was retained in the sample (by gender, language of instruction, nationality, years of study and degree programmes). The study was conducted using the Google Forms application. The main research methods were content analysis of scholarly literature (more than 40 international sources), as well as analysis based on the results of the sociological survey of students in Kazakhstan.
\end{abstract}

\section{Acknowledgments}

This article was written within the framework of the research project AP09058341 "Transformation of the values of Kazakhstani system of higher education in the conditions of a multicultural and globalizing world", implemented by the research group of Abylai Khan KazUIR \& WL with the support of the Ministry of Education and Science of the Republic of Kazakhstan in 2021-2023.

We would like to express our gratitude to the researchers of Abylai Khan KazUIR \& WL for their help in conducting a sociological survey: the head of department, candidate of pedagogical sciences, O. Ya. Kim, senior teacher S. S. Kultaeva, scientific researcher A. Nugumanova, senior teacher M .M. Userbaeva.

\section{For citation}

Ashilova M. S., Begalinov A. S., Begalinova K. K. The collapse of neoliberal concept of education in the COVID19 era and the prospects for post-COVID education. Science for Education Today, 2022, vol. 12 (1), pp. 30-54. DOI: http://dx.doi.org/10.15293/2658-6762.2201.02

曰Corresponding Author: Madina S. Ashilova, madina.almatytv@mail.ru

(C) Madina S. Ashilova, Alibek S. Begalinov, Kalimash K. Begalinova, 2022 


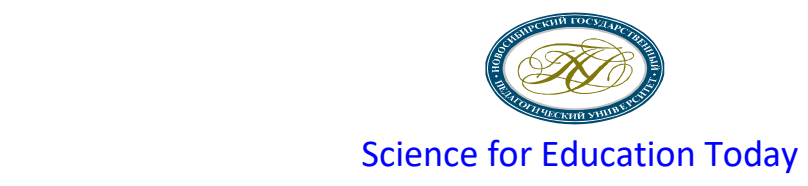

2022, vol. 12, issue 1 http://en.sciforedu.ru/

ISSN 2658-6762

Results. The authors revealed that if at the very beginning researchers paid attention to such negative aspects of the pandemic as poor technical equipment, Internet failures, unpreparedness of academic staff and students for online learning, the growth of student debts due to job loss, etc., then it soon became clear that the pandemic affected not only the external (economic, technical) side of education, but also its very essence. Today, researchers all over the world are critically analyzing the foundations of modern higher education - neoliberal concepts that have dominated in different countries since the late twentieth century and the development of globalization. It is shown that the current global educational crisis has not been caused by the pandemic, but by the unaccounted negative consequences of the deep penetration of neoliberalism ideas into society (market relations, uncontrolled competition, weakening of the role of the state, weak support for social sectors of the economy, etc.). The authors argue that societies with a developed system of neoliberal higher education experience more stress than developing, traditional ones like Kazakhstan, since the basis of education of the former is mainly the market and monetary-market relations, the basis of the latter is moral, intangible values of education.

Conclusions. Exploring the prospects of post-secondary education based on international research investigations, the authors have put forward the ideas about the need to abandon neoliberalism in favor of greater humanization, fundamentalization and ecologization of education, strengthening state control and financing. The authors consider this as the only possible form for progressive development of higher education after the pandemic.

Keywords

Neoliberalism; COVID-19 pandemic; Higher education; Philosophy of education; Postsecondary education; Well-being of youth.

\section{Introduction}

The coronavirus pandemic, which has spread widely around the world in 2020, has not pass by any area of human activity. It pushed some industries towards rapid growth, while other areas significantly slowed down. As for the education sector, the pandemic has not only changed the format of education, but also seriously raised the question of the essence of education. At first, it was believed that the main negative factors of the pandemic were disruptions in the work of educational institutions, poor technical equipment, interruptions in the Internet work, limited access to educational products, weak digital training of teachers and students, growing unemployment in the educational sphere, growth of student debts, etc. ${ }^{1}$. But it soon became clear: all this is just the top of the iceberg. The
COVID-19 pandemic has shaken the essential foundations of education: its ability to exist.

The relevance of this study is due to the fact that the coronavirus pandemic is a fairly new phenomenon. And, contrary to all expectations, it has penetrated quite deeply into the educational process, slowly transforms it, changes both the external (formal) side of education and the internal (content).

Education was suddenly devalued. Students began to realize clearly that a loan taken for educational reasons, most likely, will not return a debit in the form of a prestigious job or salary. The investments are unlikely to be ever paid off at all. The situation before the pandemic had been already extremely tense, in this area there were such problems as a reduction in student

${ }^{1}$ UN Concept Note. Education in the COVID-19 era and
beyond. $\quad$ UN, $2020 . \quad$ URL: https://www.un.org/sites/un2.un.org/files/policy_brief__education_during_covid-19_and_beyond_russian.pdf 
enrollment $^{2}$, a student debt crisis $^{3}$, low wages of graduates, growing unemployment, etc. The pandemic significantly exacerbated these problems.

"Is it worth studying further?" ${ }^{4}$ - this question is asked by millions of students in the United States. Most young people in Australia claimed that they were unlikely to retire before the age of 65 , find their dream house or work related not only to paying bills ${ }^{5}$. The average life satisfaction score among English students is 5.8 (out of 10); however, it is still significantly lower in comparison to the adult population in the UK $(7.0)^{6}$.

All these factors state about a serious disappointment of student youth with the sphere of higher education, calls into question the need for further education and the employment prospects after graduation.

At the same time it becomes obvious that after such total criticism there can be no question of a return to "normality". The current concept of higher education, thanks to the pandemic, has reached its bottom. We may observe a shift in educational paradigms soon. The neoliberal concept in education is running out of itself.

The purpose of this paper is to study the well-being and values of student youth in the world (based on research of foreign scientists) and in Kazakhstan, the largest country in Central Asia

\footnotetext{
${ }^{2}$ Where Did All the Students Go? The Chronicle of Higher Education. 2019. URL: https://www.chronicle.com/article/where-did-all-the-students-go

3 Student Loans Owned and Securitized, Outstanding. FRED, Federal Reserve Bank of St. Louis. FRED, Federal Reserve Bank of St. Louis. 2021. URL: https://fred.stlouisfed.org/series/SLOAS

${ }^{4}$ Hiler T. How COVID-19 Made Higher Education Value a Top Priority. Third way, 2020. URL: https://www.thirdway.org/memo/how-covid-19-madehigher-education-value-a-top-priority

${ }^{5}$ Zhou N. Young Australians delaying life goals due to pandemic and feel pessimistic about future. The Guard-
}

(based on a survey conducted among 1000 students).

Among the tasks: researching foreign literature on neoliberalism and the impact of the pandemic on higher education, analyzing foreign surveys, conducting our own sociological survey in Kazakhstan, conducting a comparative analysis.

More serious scientific works are required to understand what education should be after pandemic and what new educational paradigms should be founded. In this study we will only try to figure out which factors have influenced most significantly on the effectiveness of higher education and what prospects for post-COVID education we may have in future.

\section{Literature review}

The neoliberal educational concept, as well as the impact of pandemic on the higher educational system are now being carefully studied by various researchers around the world.

The origins of neoliberalism have been well discussed in numerous papers (see, e.g., Centeno and Cohen [1], Hursh and Henderson [2], and Peters [3]).

It should be noted that many authors tend to view neoliberalism as the dominant ideology of globalization $^{7}$, a global agenda [4]. Having emerged in the economic theory in the middle of

ian. 2020. URL: https://www.theguardian.com/business/2020/nov/05/young-australians-delaying-life-goalsdue-to-pandemic-and-feel-pessimistic-about-future

${ }^{6}$ Office for national statistics. Coronavirus and higher education students: England, 4 to 12 May 2021. URL: https://www.ons.gov.uk/peoplepopulationandcommunity/healthandsocialcare/healthandwellbeing/bulletins/coronavirusandhighereducationstudents/england4to12may2021

${ }^{7}$ Antipov D., Bakirov E. Neoliberalism in Education: An Analysis of the Global Economy of Education. Economy philosophy, 2017, no. 1, pp. 74-91. URL: https://www.elibrary.ru/item.asp?id=29257209 
XXth century, neoliberalism soon penetrated into all other areas of human life. In the field of education the neoliberal concept has dominated for the last 20 years (since the end of the 90s) [5].

Academic capitalism is broadly defined as "the involvement of colleges and faculty in market-like behaviors," and these behaviors have seemingly been increasing over the past twenty years ${ }^{8}[6]$. So, the essence of neoliberalism in the educational system is the inclusion of education in the market economic model. In this respect, economic globalization, "West's triumph", which led to the expansion of capitalism into the higher educational system, is considered to be the trigger of growth ${ }^{9}$.

The neoliberal paradigm of higher education is characterized by a market approach to the admission of students (mostly foreign) ${ }^{10}$, global capitalization and commercialization of higher education, as well as the integration of financial markets [7].

It happened well ahead of the pandemic when scientists admitted that neoliberalism in educational policy had a tendency to generate a technical rationalistic approach to knowledge and its values [8, p. 509].

The goal of education shifts from the intention to educate autonomous and hard-hitting participants of democracy to the desire to produce a positive and able-bodied workforce [9].

Peters [10] believes that we have entered the phase of knowledge capitalism. This shift has also been characterized as cognitive (bio) capitalism [11], since the knowledge economy is based on the constructions of intangible (intellectual and affective) labor, rather than physical labor as the production basis [12]. This resulted in the upbringing of an economically responsible and

\footnotetext{
${ }^{8}$ Ashilova M., Begalinov A., Begalinova K. Kazakhstani Higher Education. Overview. Almaty, 2021. 240 p.

${ }^{9}$ Klak T. Globalization and Neoliberalism: The Caribbean Context. Rowman \& Littlefield. Lanham, 1998.
}

"economically selfish" person [13, p. 314]. Phillips and Ilkan argue that now the responsibility falls on people who must "become self-regulating ... and market-aware" [14, p. 397].

The value of knowledge within the frameworks of neoliberal educational paradigm lies in its usefulness for the development of human capital [15, p. 222]. Thus, the role of schools and universities in personal education has changed markedly over the past thirty years: graduation can be viewed as the creation of an intellectual worker [4].

The given interpretation of education and its goals, as well as the entire neoliberal approach to education in the era of pandemic, show their total inconsistency.

The current coronavirus pandemic, according to Giroux, is more than a medical crisis, it is also a political and ideological crisis. It is a crisis rooted in years of neglect by neoliberal governments that denied the importance of public healthcare and public welfare while refusing to fund the institutions which made their existence possible. At the same time, this crisis cannot be separated from a crisis of huge inequalities in wealth, income and power. It cannot be separated from the crisis of democratic values, education and environmental destruction [16].

The COVID-19 pandemic has brought the contemporary global university into further crisis [17].

The major "clients" and "consumers" of modern society are students who grow aware of the failure of the neoliberal educational paradigm. Studies around the world demonstrate students' dissatisfaction with higher education and, as a result, with the prospects for their lives in the pandemic era.

\footnotetext{
${ }^{10}$ Went R. Globalization: Neoliberal Challenge. Radical Responses. Pluto Press, London, 2000.
} 
Thus, as follows from the survey conducted by Goodwin Simon Strategic Research in the USA, American respondents showed less clarity about their goals and ideas for their future work or career, many students in the USA are not sure whether they should continue to study at university ${ }^{11}$.

In Australia, the majority of students is unsure of their financial future $(64 \%)$ and postpone the process of achieveing their basic life goals due to the Covid-19 pandemic (69\%). This was shown by a survey that revealed widespread pessimism. $84 \%$ of 1,000 young Australians said that it had become harder to get a job after Covid$19^{12}$.

In Russia, $57.2 \%$ of respondents among students said that they were losing control over the situation and their lives, felt the loss of their goals, absence of plans and total uncertainty ${ }^{13}$.

According to a large-scale study conducted by Deloitte, which covered 27.5 thousand people around the world, the most important concerns of young respondents are related to family wellbeing $(41 \%)$, long-term financial future $(41 \%)$ and career prospects $(40 \%)^{14}$.

The crisis in higher education also affected the mental well-being of young people.

\footnotetext{
${ }^{11}$ How COVID-19 and Other Events are Shaping Young People's Perceptions of the Future. URL: Equitable Futures National Youth Poll 2020-2021. https://www.equitablefutures.org/covid19/

${ }^{12}$ Zhou N. Young Australians delaying life goals due to pandemic and feel pessimistic about future. The Guardian. 2020. URL: https://www.theguardian.com/business/2020/nov/05/young-australians-delaying-life-goalsdue-to-pandemic-and-feel-pessimistic-about-future

${ }^{13}$ Young people developed pandemic fears. 2020. URL: https://urfu.ru/ru/news/35209/

${ }^{14}$ Deloitte investigated the mood of millennials during the pandemic. 2020. URL: https://frankrg.com/20855

15 The impact of COVID-19 on the mental health of adolescents and youth. 2020. URL: https://www.unicef.org/lac/en/impact-covid-19-mentalhealth-adolescents-and-youth
}

According to a UNICEF survey on the impact of COVID on the mental health of adolescents and young people, conducted in 9 countries around the world and organized among over 8,000 respondents, one in three responded that felt anxious $(27 \%)$ and another $15 \%$ felt depressed. $43 \%$ of girls and $31 \%$ of boys were pessimistic about the future ${ }^{15}$.

According to the International Labor Organization's report Youth and the COVID-19 Pandemic: Impact on Jobs, Education, Rights and Mental Health, $50 \%$ of young people have the potential to experience feelings of anxiety or depression, and another $17 \%$ are likely to have already experienced these problems ${ }^{16}$.

In Canada, one out of four student respondents noted that the stress level was above critical thresholds [18].

In the USA analysis based on student interviews showed increased stress and anxiety due to the outbreak of COVID-19 (71\%) ${ }^{17}$.

Thus, COVID-19 pandemic has exposed the moral vacuum and economic gaps at the heart of the neoliberal "development" model that has dominated global economic relations since the $1980 \mathrm{~s}^{18}$. It is an ideology which respects market and discards everything that makes us humans ${ }^{19}$.

\footnotetext{
16 Youth and COVID-19: impacts on jobs, education, rights and mental well-being. Due to the COVID-19 pandemic, more than 70 percent of young people are unable to study properly. Report of the International Labor Organization. 2020. URL: https://www.ilo.org/moscow/news/WCMS_753125/lang--ru/index.htm

${ }^{17}$ How COVID-19 and Other Events are Shaping Young People's Perceptions of the Future. Equitable Futures National Youth Poll 2020-2021. URL: https://www.equitablefutures.org/covid19/

${ }^{18}$ Monbiot G. Neoliberalism - the ideology at the root of all our problems. The Guardian. 15 April. 2016. URL: https://www.theguardian.com/books/2016/apr/15/neoliberalism-ideology-problem-george-monbiot

${ }^{19}$ Metcalf S. Neoliberalism: the idea that swallowed the world. The Guardian. 18 August. 2017. URL:
} 
Instead of using the economy at the service of citizens, neoliberalism forced workers to serve the needs of market ${ }^{20}$.

The educational system does not prepare students for life. It prepares them only for a profession or work. They must learn to cope with life on their own ${ }^{21}$.

As a result, today there is a situation of total crisis generated by the dominance of neoliberal attitude to the world: the medical crisis quickly spread to other spheres of life and affected the higher education system very sensitively.

\section{Methods}

This study is designed to examine the wellbeing and values of student youth in Kazakhstan in order to reveal how significantly the pandemic has hit the views of young people and their prospects for future. The study will also show how deeply the neoliberal ideas in education have penetrated into Kazakhstan's universities and how this has affected the views of young people about their future.

The study involved students of higher educational institutions of the Republic of Kazakhstan. In total 1000 people were surveyed. The study covered all 14 regions of Kazakhstan, students of different courses (from 1 to 4), different departments (studying in Russian, Kazakh and English), different specialties (technical, humanitarian, medical, etc.).

However, the selection series retained the bulk of students (male / female population, the share of large metropolitan areas and small towns, popular and unpopular specialties, etc.).

\footnotetext{
https://www.theguardian.com/news/2017/aug/18/neoliber alism-the-idea-that-changed-the-world

20 McCloskey S. COVID-19 has Exposed NeoliberalDriven 'Development': How can Development Education Respond? Policy and practice. A development edu-
}

The study was limited to the online format, since a quarantine situation is still in effect in Kazakhstan. Students study in the remote mode, social contacts in many regions are significantly limited. The research was conducted with the use of Google Forms application. Based on the analysis of sociological survey, the life priorities of Kazakhstani students, their expectations from studying at universities, as well as the level of satisfaction with education during pandemic are shown.

Out of 1000 students of Kazakhstan universities who took part in the survey, $78.5 \%$ were women and $21.5 \%$ were men.

The positions of students from all 14 regions of Kazakhstan are presented. The largest number of survey forms came from Almaty and Almaty region (31.8\%), Shymkent and Turkestan region $(11 \%)$ and Karaganda (10.4\%). $5.9 \%$ each - from Kostanay and Pavlodar, $5.7 \%$ - from East Kazakhstan region, $5.4 \%$ - from Kyzylorda, 5.1\% - from Aktobe, $4.6 \%$ - from Atyrau, $4.4 \%$ - from North Kazakhstan region, $2.9 \%$ - from WKO, $2.6 \%-$ from Nur-Sultan and Akmola region, $2.5 \%$ from Mangistau region, $1.8 \%$ - from Taraz and Zhambyl region.

The survey involved students from various departments and specialties, including: students of humanities $(45.8 \%)$, education $(17.2 \%)$, social sciences, economics and business (13.7\%), natural sciences $(5,2 \%)$, technical sciences and technologies (5\%), services $(4.5 \%)$, arts $(3.3 \%)$, law $(2.6 \%)$, agriculture $(2.3 \%)$, medicine $(2 \%)$.

According to the courses of study, the respondents were distributed as follows: 1st

cation review. 2020. pp. 174-185. URL: https://www.developmenteducationreview.com/issue/issue-30/covid19-has-exposed-neoliberal-driven-'development'-howcan-development-education

${ }^{21}$ Gupta A. Value education in higher education. 2020. DOI: https://doi.org/10.13140/RG.2.2.16787.84005 
course $-47.3 \%$, 2nd course - $21.1 \%$, 3rd course $-20 \%, 4$ th course $-11.6 \%$.

By ethnical identity, the survey was mainly passed by students of Kazakh nationality $(85.1 \%)$, as well as Russian (5.3\%), Korean (2.7\%), Uzbek (1.3\%), Uyghur (1.2\%)) and the rest (less than $1 \%$ : Tajik, Tatar, German, etc.).

By age, the respondents presented the opinions of students of higher educational institutions of the Republic of Kazakhstan under 18 years old (46.2\%), 19-21 years old (48.3\%), 22-24 years old $(4.8 \%)$ and over 24 years old $(0.7 \%)$.

Thus, the representative composition of the participants in the online sociological survey reflected the diversity of participants' judgments

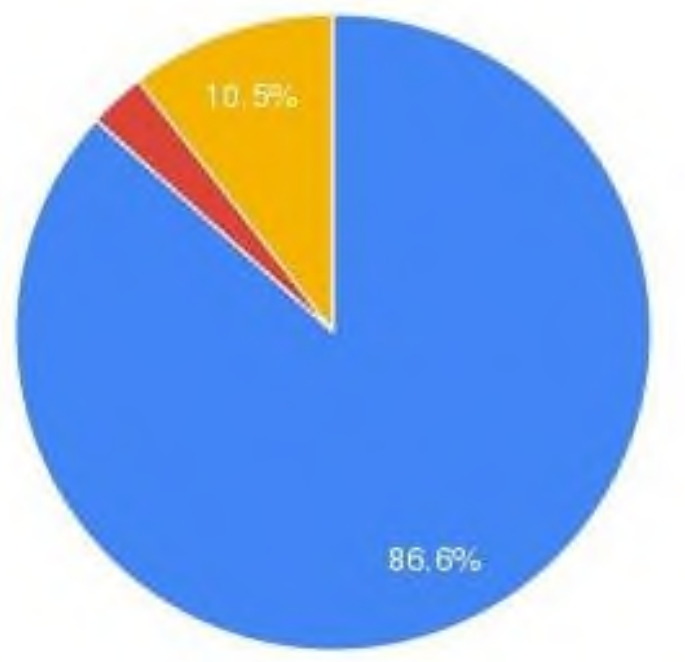

on topical issues of modern higher education and can be considered as a reliable source of conclusions.

\section{Results}

Higher education in Kazakhstan "as seen by respondents"

The study revealed the following trends in the views, value orientations and well-being of student youth in Kazakhstan:

To the question "Do you have a definite goal in your life?" the overwhelming majority of respondents answered positively $(86.6 \%$ ) (see Figure 1$)^{22}$. Only $2.9 \%$ of students noted that they had no goal in life, $10.5 \%$ - found it difficult to answer.

Figure 1. Having a goal in the lives of the respondents

Among the goals the respondents most often noted: to become a qualified specialist, to fulfil one's potential, career growth, creating a family, achieving financial independence, success in business, traveling.

In the answers to the question "What is the most valuable thing to you in your life?" (see
Figure 2) ${ }^{23}$ the overwhelming number of respondents indicated family $(60.9 \%)$, health $(14.1 \%)$, career $(9.5 \%)$, money $(4.8 \%)$ and education (2.8\%). Everything else (friends, love, etc.) took $7.9 \%$.
${ }^{22}$ Ashilova M., Begalinov A., Begalinova K. Kazakhstani Higher Education. Overview. Almaty, 2021. 240 p.
${ }^{23}$ Ashilova M., Begalinov A., Begalinova K. Kazakhstani Higher Education. Overview. Almaty, 2021. 240 p. 


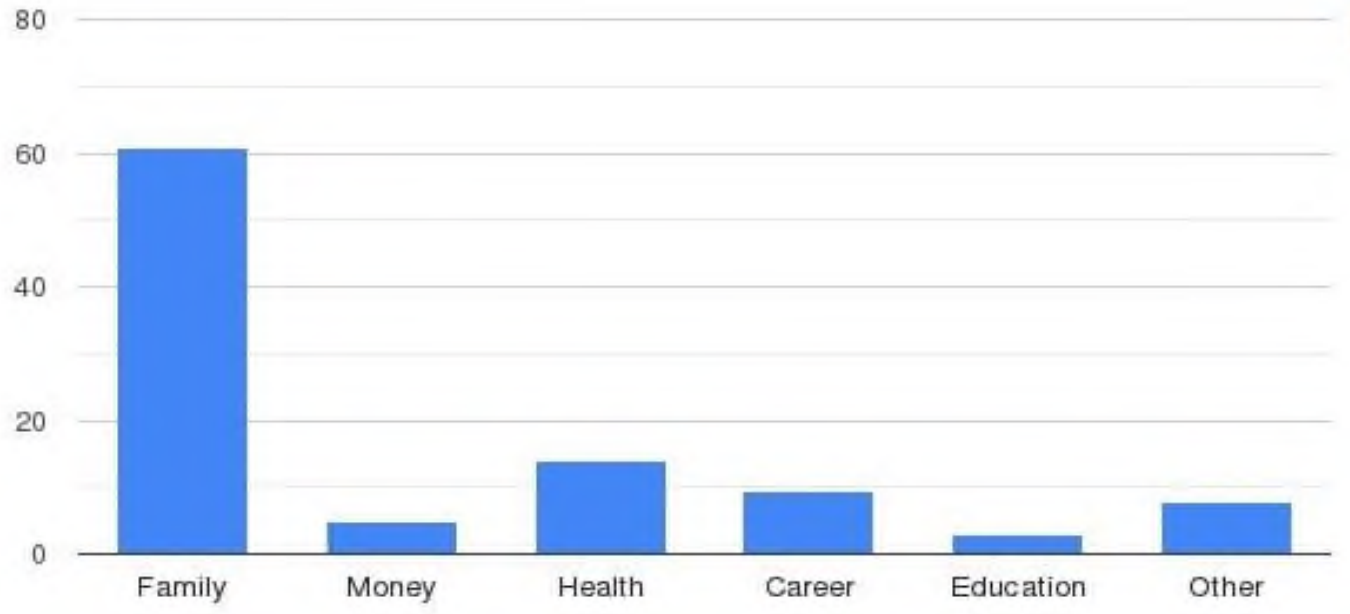

Despite all pandemic challenges and difficulties of education in recent years, respondents generally highly appreciate the importance of university education. In particular, the acquisition of professional skills is significant for them. So, in their opinion, studying at university is important because it allows you to acquire a profession (44.7\%), become educated (33.4\%), prepare for an independent life $(15.1 \%)$, establish yourself among close people (1, nine \%). Also, studying at university,

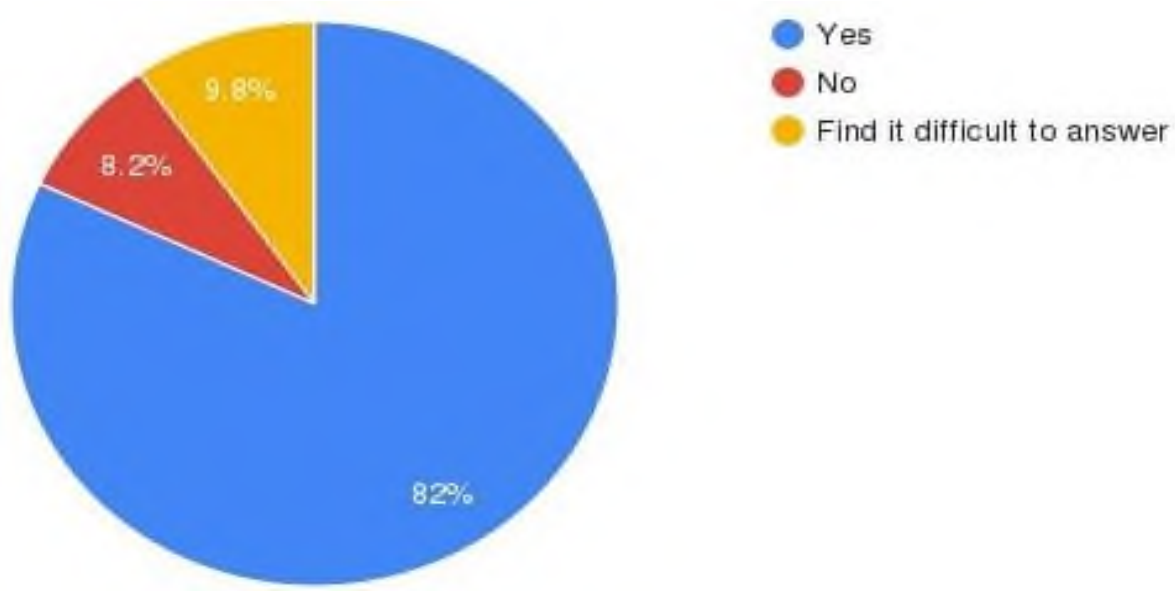

Figure 3. The role of higher education in career and self-realization according to respondents (4\%), helps to become rich, broaden horizons, get a diploma, establish communication with people and peers, avoid military service, etc.

Most of the respondents believe that higher education of good quality will help ensure a successful career and self-realization. 820 respondents $(82 \%)$ supported this position, 82 respondents $(8.2 \%)$ did not, another 98 found it difficult to answer $(9.8 \% \text { ) (see Figure } 3)^{24}$.

A., Begalinova K. Kazakhstani

${ }^{24}$ Ashilova M., Begalinov A., Begalinova K. Kazakhstani
Higher Education. Overview. Almaty, 2021. 240 p. 


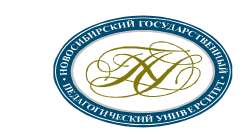

Science for Education Today

2022, vol. 12, issue 1 http://en.sciforedu.ru/

ISSN 2658-6762

In the next question the respondents were asked to think about the results of their future profession. Most of the students agreed with the statement that work should bring pleasure $(49.8 \%)$, another $22.3 \%$ believe that work should be useful to people. No less part of the respondents expressed the opinion that work should bring a high income $(21.7 \%)$ and be prestigious $(6.2 \%)$ (see Figure 4$)^{25}$.
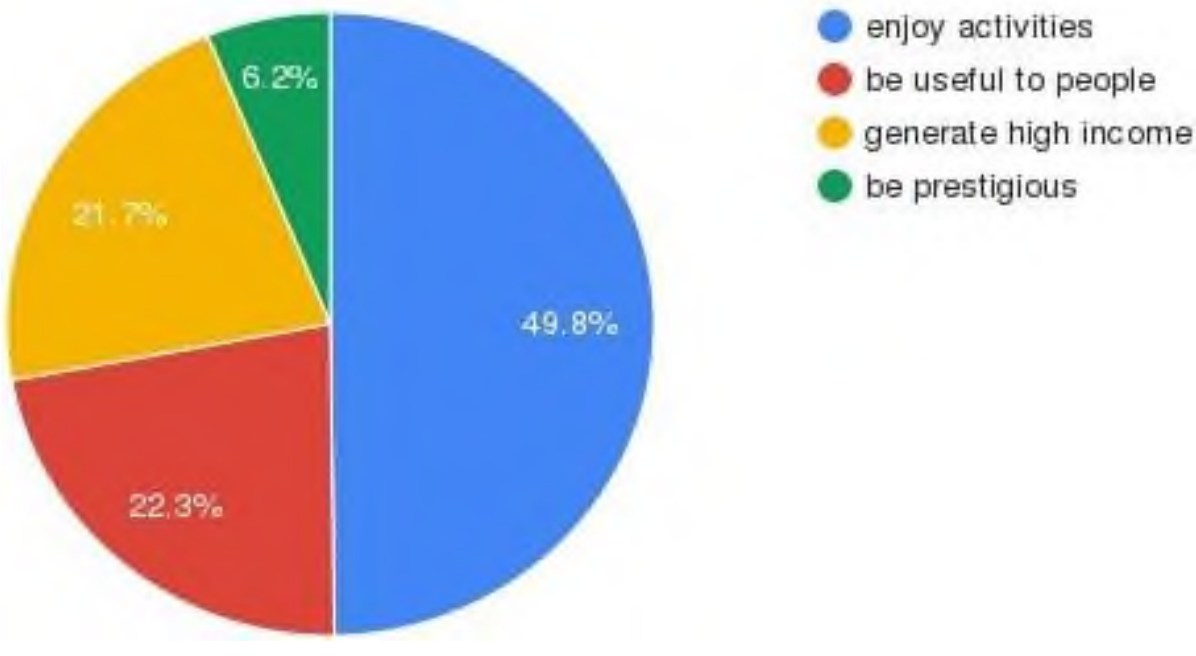

Figure 4. Characteristics of future work

To the question about the importance of material values, the respondents' answers formed as follows: for most of the students, spiritual values were more important than material ones

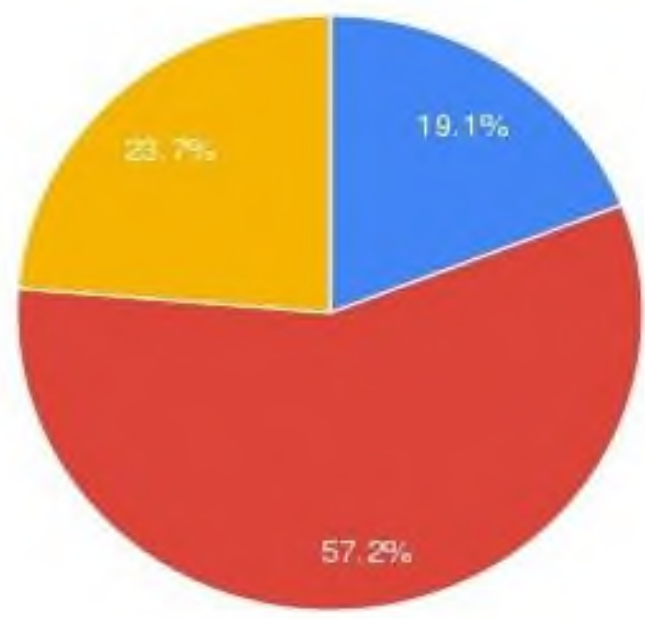

$(57.2 \%)$. For $19.1 \%$ - material values are the most important things in life. Another $23.7 \%$ of students found it difficult to answer (see Figure 5$)^{26}$.

Figure 5. The importance of material and spiritual values

\footnotetext{
${ }^{25}$ Ashilova M., Begalinov A., Begalinova K. Kazakhstani

${ }^{26}$ Ashilova M., Begalinov A., Begalinova K. Kazakhstani Higher Education. Overview. Almaty, 2021. 240 p. Higher Education. Overview. Almaty, 2021. 240 p.
}

for me material values are the most important thing in life

spiritual values are more important to me than material

find it difficult to answer 
When asked what feelings the respondents most often felt, the answers were as follows: normal vitality, feel of calm (48.5\%), emotional uplift, cheerfulness (30.9\%). It should be noted that some respondents $(9 \%)$ felt a state of imbalance, a feeling of anxiety, another part $(4.8 \%)$ were depressed, and $4.2 \%$ had a feeling of indifference to everything (see Figure 6) ${ }^{27}$. Among other answers, students indicated more often negative feelings, such as emotional carousels, fear, fatigue, loneliness, aggression, depression, sadness, shame, apathy, anxiety, guilt, disgust, etc. Out of the total number of answers, every fifth student noted a negative feeling.

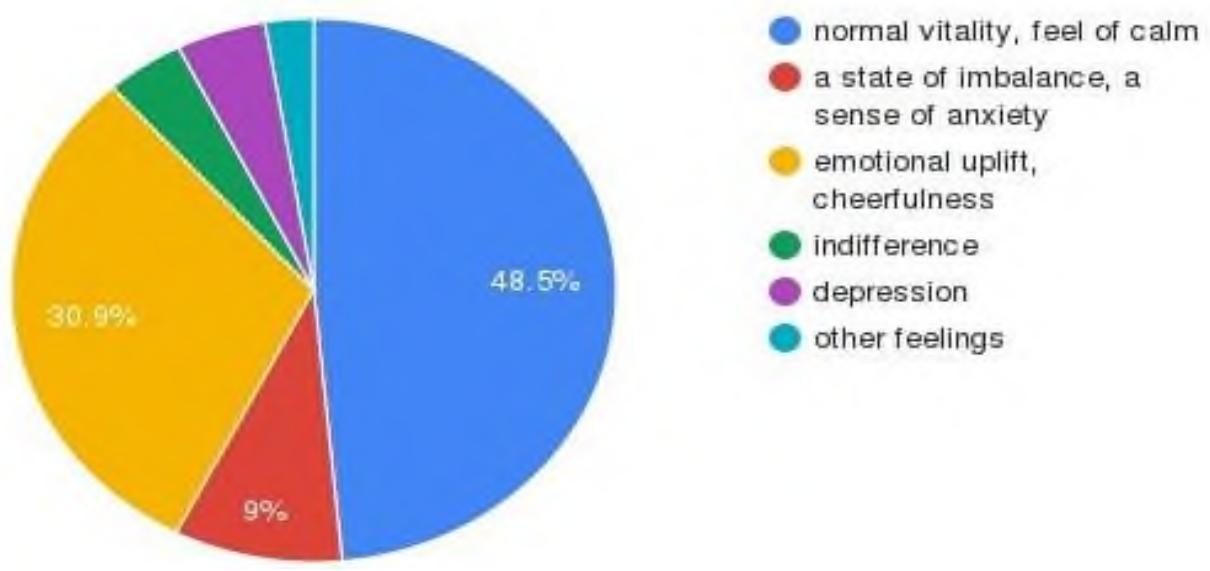

Figure 6. Feelings experienced by respondents

To the next question in the survey "What causes fear and uncertainty in your future life?", students noted fear of not fulfiling themselves (54\%), problems with employment (11.4\%), fear of being left without a livelihood (11.2\%), problems with health $(10.3 \%)$, problems with marital status $(8.5 \%)$ (see Figure 7$)^{28}$. In their responses, the students also shared that they were worried about the fear of not finding themselves, fear of unknown, political situation in the world, fear of prolonged depression, addiction, fear of future obstacles, etc.
${ }^{27}$ Ashilova M., Begalinov A., Begalinova K. Kazakhstani Higher Education. Overview. Almaty, 2021. 240 p.
${ }^{28}$ Ashilova M., Begalinov A., Begalinova K. Kazakhstani Higher Education. Overview. Almaty, 2021. 240 p. 


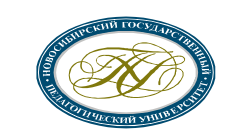

Science for Education Today

2022, vol. 12, issue 1 http://en.sciforedu.ru/

ISSN 2658-6762

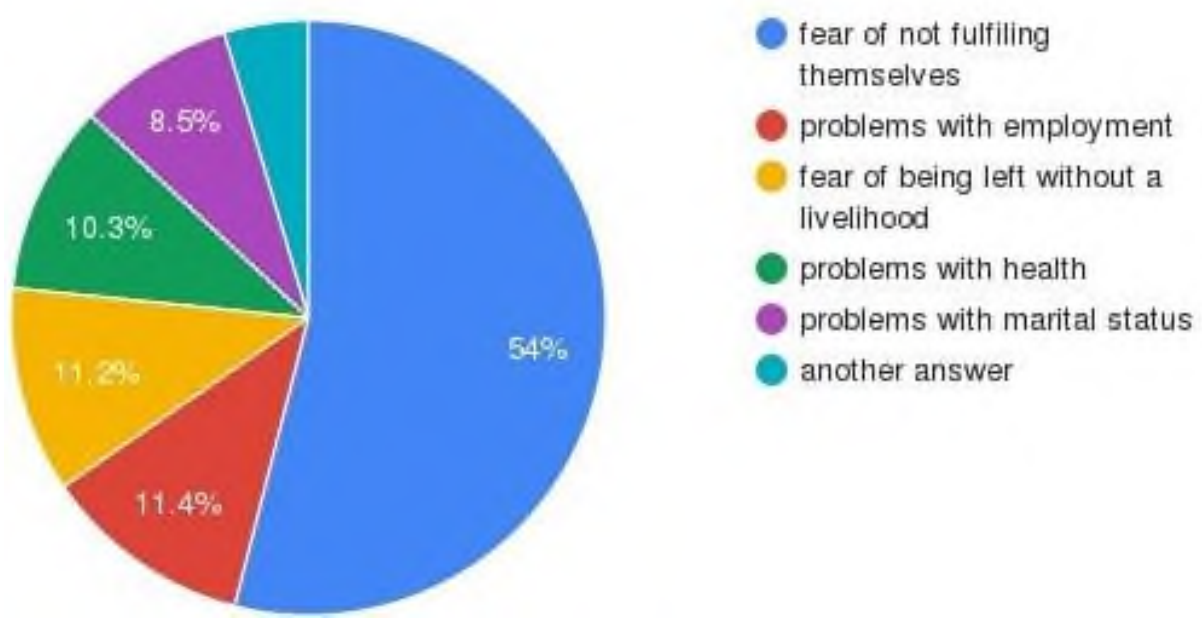

Figure 7. Fears of respondents

The coronavirus pandemic forced all universities in Kazakhstan to switch urgently to a distant format. But have universities managed to save the quality of education? Students answered this question differently: most of the respondents

$(40.8 \%)$ rated the quality of distant education as

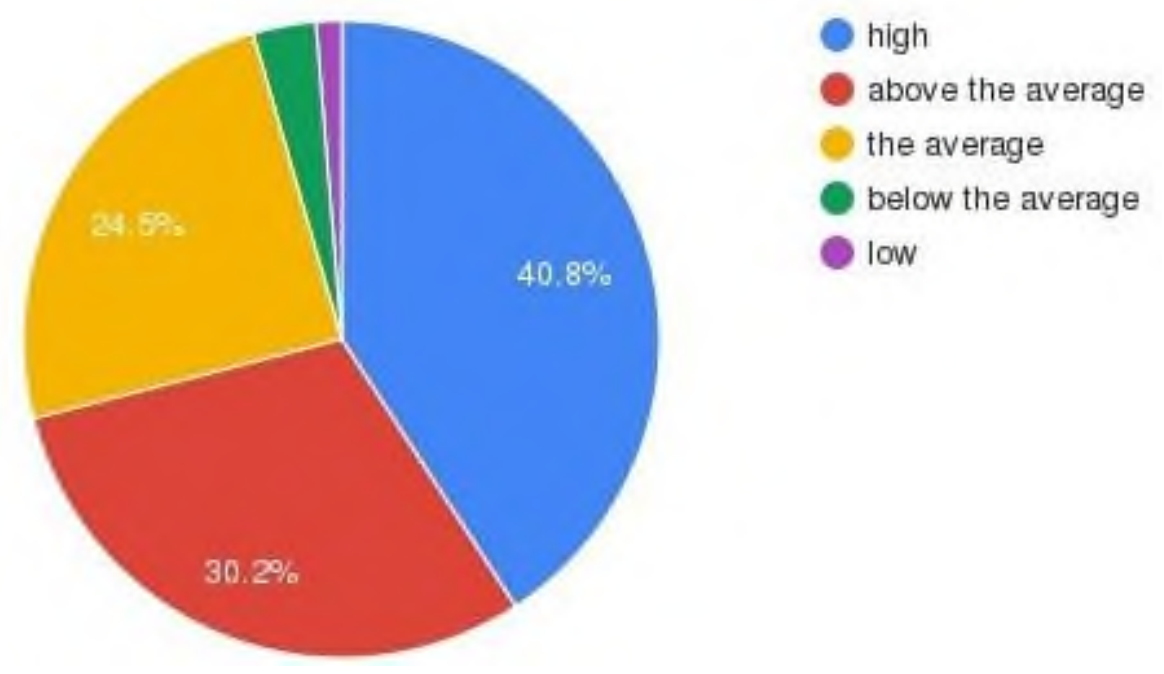

Figure 8. Distant education quality high, $30.2 \%$ - above average, $24.5 \%$ - average. A small part of students believe that the quality of education has decreased: $3.2 \%$ believe that it has become below average, and $1.3 \%$ - as low (see Figure 8$)^{29}$.

${ }^{29}$ Ashilova M., Begalinov A., Begalinova K. Kazakhstani

Higher Education. Overview. Almaty, 2021. 240 p. 


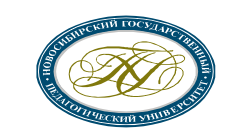

Science for Education Today

2022, vol. 12, issue 1 http://en.sciforedu.ru/

ISSN 2658-6762

The level of satisfaction with the education received at university varies from 1-5: most of the respondents gave a grade of $4(36.8 \%)$, another
$34.3 \%-5,21.9 \%-3$. A small part of the students gave a grade of $2(5.5 \%)$ and $1(1.5 \%)$ (see Figure 9) ${ }^{30}$.

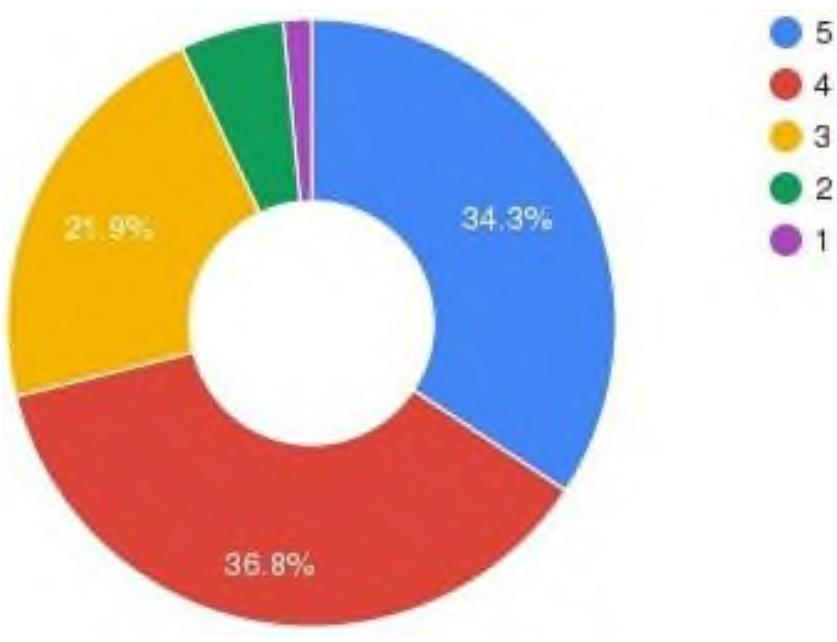

Figure 9. The rate of satisfaction with received education

When asked if your life goals coincide with your future profession, almost half of the respondents noted that partially coincided (47.6\%), another $43.3 \%$ - fully coincided. Only

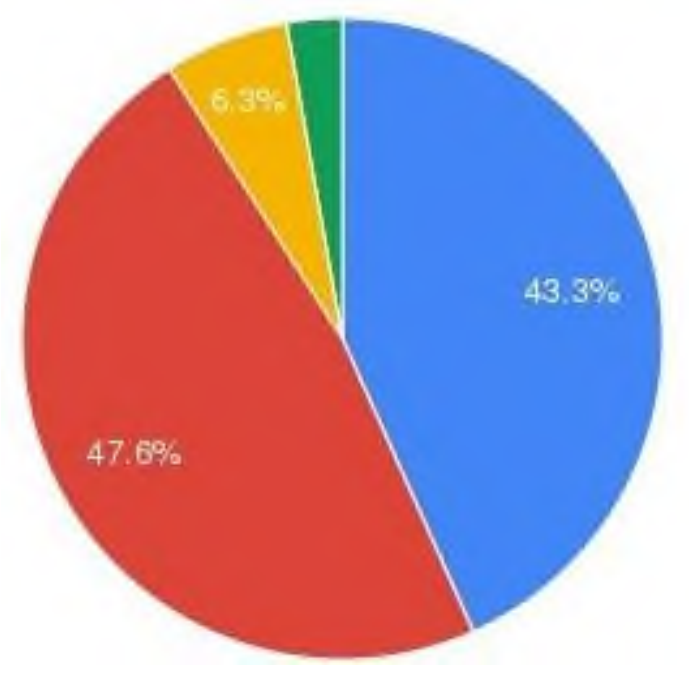

$6.3 \%$ of respondents answered negatively and $2.8 \%$ found it difficult to answer (see Figure $10)^{31}$.

Figure 10. Coincidence of life goals with the future profession of the respondents

\begin{tabular}{|c|c|}
\hline $\begin{array}{l}{ }^{30} \text { Ashilova M., Begalinov A., Begalinova K. Kazakhstani } \\
\text { Higher Education. Overview. Almaty, 2021. } 240 \text { p. }\end{array}$ & $\begin{array}{l}{ }^{31} \text { Ashilova M., Begalinov A., Begalinova K. Kazakhstani } \\
\text { Higher Education. Overview. Almaty, 2021. } 240 \text { p. }\end{array}$ \\
\hline (C) 2011-2022 Science for Education Today & All rights reserved \\
\hline
\end{tabular}


To the next question about their plans to work in their specialty in future, the overwhelming majority of respondents answered

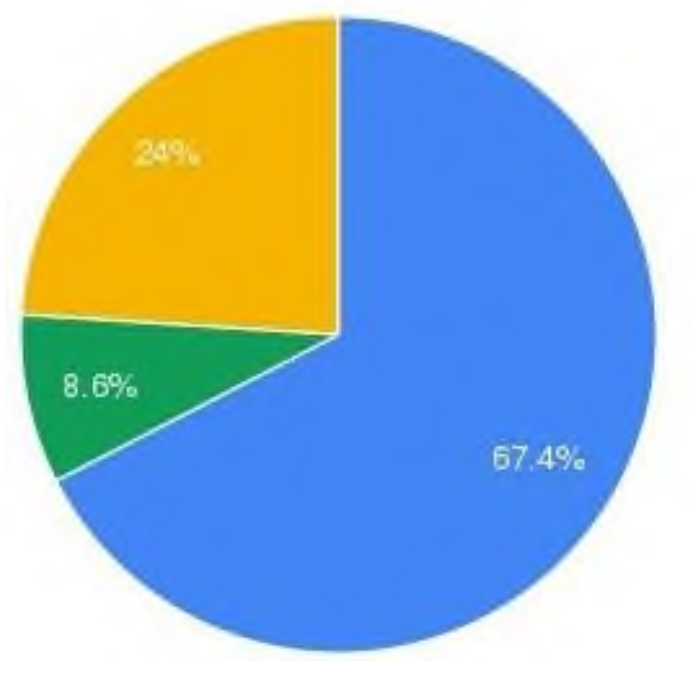

positively $-67.4 \% .24 \%$ found it difficult to answer and $8.3 \%$ of respondents did not plan to work in their specialty in future (see Figure 11$)^{32}$.

Figure 11. The respondents' plans to work in their specialty in future

Finally, in conclusion, the respondents were given the opportunity to make their proposals for improving the quality of higher education in Kazakhstan. Among the answers the following suggestions were made: for teachers - to be more objective and to treat students with greater understanding, to provide more practical lessons, to listen to young people and be able to consult with students, to make education accessible, to add financial literacy as a compulsory subject, to give more topical information at lectures, to present lecture materials in a creative way, to recommend more books for reading, to share more available information resources on the Internet, to increase salaries of teachers so that they have more motivation, to open special clubs for specialties, etc.

\footnotetext{
${ }^{32}$ Ashilova M., Begalinov A., Begalinova K. Kazakhstani Higher Education. Overview. Almaty, 2021. 240 p.
}

\section{Discussion}

Based on the research carried out in Kazakhstan, the largest country in Central Asia, we come to the following conclusions:

1) the pandemic did not significantly affect the existence of life goals and attitudes of Kazakhstani youth.

As the survey shows, the majority of Kazakhstani students, despite the pandemic and all its negative consequences, have not lost their clear and definite life goals. They stick to their goals up to current day. For most, this goal is in professional and career growth, self-realization, and family creation. For the absolute majority of the surveyed students (over $90 \%$ ), their life goals still partially or completely coincide with their chosen professions.

In this context, Kazakhstani students are more resistant to the negative consequences of the 
pandemic than young people are from other countries. It seems that the reason for this is family support. Kazakhstan is the largest Central Asian country with a prominent oriental mentality, where kinship ties are still important in the lives of young people. Thanks to this, students have the opportunity to worry less about their financial well-being, relying on family support. And, as a result, the pandemic has less impact on their life values and goals.

2) In the value picture of the world of Kazakhstani students, the predominant place is occupied by the family. Career and money amount to small $9.5 \%$ and $4.8 \%$, respectively.

Globalization and neoliberal attitudes with their call for unlimited competition, free market and individualism, as we see, have not penetrated deeply into Kazakhstani society yet. By inertness the attitudes of traditional society with the cult of family and traditions are strong. Therefore, the majority of Kazakhstani students, unlike Western students, do not really think about the prospects for career growth and material returns in the form of employment, prestigious work or high wages, preferring to establish family relationships.

From this it can be concluded that young people in Kazakhstan do not draw a direct parallel: tuition fees at university (credit) $=$ high salary (debit). On the contrary, only every fifth student noted the necessity of the future profession profitability. While almost half of the surveyed respondents claimed for the need to enjoy work and another quarter - for the usefulness of it to people. This suggests that neoliberal attitudes and objections to education as an instrument of future financial well-being among students in Kazakhstan are still extremely weak.

3) Despite the difficulties that have arisen in the pandemic era, the faith of Kazakhstani students in higher education is still strong. The quality of distant education in Kazakhstan is assessed by young people as high, but to a grade of 4 .

Unlike foreign students, who are increasingly asking the question "Is it worth continuing their studies at university?", the overwhelming majority of Kazakhstan students $(82 \%)$ are sure that higher education will help them to get successful career and self-realization. It seems that the reason for this is in a consistent and stable society, strong family traditions developed in Kazakhstan after the USSR collapse, and in a social support of the state.

Kazakhstan is a country with small population (only 19 million people). And there are fewer problems with admission to higher educational institutions, with employment and other issues than in other countries of the world characterized by a high population density, migration, military conflicts, etc. Therefore, students in Kazakhstan feel more protected and look forward with greater optimism.

4) Nevertheless, the global trends and pandemic mood did not pass by Kazakhstani students. Every fifth student in Kazakhstan experiences negative feelings (a state of imbalance, anxiety, depression, indifference, etc.). Among the main fears of young people: fear of not fullfilling oneself, problems with employment, fear of being left without a livelihood, health problems and marital status.

In this regard, Kazakhstan is no exception. Just like young people from other countries in the world, stress and depression among young people is growing in Kazakhstan. However, the level of stress, as shown by the survey, is not as high as among students from other countries.

For comparison, according to the UNICEF survey on the impact of COVID on mental health of adolescents and young people, conducted in 9 countries of the world and covering more than 8 thousand respondents, one in three responded that felt anxiety $(27 \%)$ and another $15 \%$ were 
depressed. $43 \%$ of girls and $31 \%$ of guys were pessimistic about the future ${ }^{33}$.

According to the International Labor Organization's report "Youth and COVID-19 Pandemic: Impact on Jobs, Education, Rights and Mental Health", $50 \%$ of young people have the potential to experience feelings of anxiety or depression, and another $17 \%$ are likely to have already experienced these problems ${ }^{34}$.

In Russia, along with the growth of traditional fears, young people started to have new, pandemic ones. These fears were either absent before the coronavirus, or were very weak. According to the study, $88 \%$ of survey participants noted that the pandemic increased their state of anxiety. $65.9 \%$ of respondents were worried about the state of health, both their own and their relatives and friends. Fears about the future are among leaders $(57.2 \%)$ : respondents note that they are losing control over the situation and their lives ${ }^{35}$.

In Canada, one out of four student respondents noted that the stress level was above critical thresholds [18].

In the USA analysis based on student interviews showed increased stress and anxiety following the COVID-19 outbreak (71\%). Multiple factors that contributed to increased levels of stress, anxiety and depressive thoughts among students were identified. These include fear and anxiety for their own health and for the health condition of people close to them (91\%), difficulties with attention concentration (89\%), sleep disturbances $(86 \%)$, decreased social

\footnotetext{
${ }^{33}$ The impact of COVID-19 on the mental health of adolescents and youth. 2020. URL: https://www.unicef.org/lac/en/impact-covid-19-mentalhealth-adolescents-and-youth

${ }^{34}$ Youth and COVID-19: impacts on jobs, education, rights and mental well-being. Due to the COVID-19 pandemic, more than 70 percent of young people are unable to study
}

interactions due to physical distance ( $86 \%)$, and increased anxiety for their academic progress $(82 \%)^{36}$.

As we can see, the level of stress and depression among Kazakh youth is less than among young people in Europe, America or Russia. However, Kazakhstani students did not escape the negative impact of pandemic and also began to experience more negative feelings.

Abstracting from the results of study conducted among students in Kazakhstan during the COVID-19 pandemic, as well as from the results of other world studies, we will summarize some theoretical results.

The neoliberal model of university organization, which has become especially popular in the world and post-Soviet countries after the USSR collapse, does not justify itself. Having become the ideology of globalization and penetrating deeply into the sphere of education, neoliberalism enables the disintegration of personality rather than its formation. This is evidenced by disorientation of student youth in the USA, Europe and Australia - the market chain "education-skill" - "prestigious work-high income" was interrupted. And the meaning of whole education now is also under the question. In this regard, in countries with a high level of neoliberalism penetration, the level of stress, anxiety and depression among young people is growing especially rapidly.

In Kazakhstan, neoliberal ideas in education meet with widespread opposition among teachers and public figures, many of whom were brought

properly. Report of the International Labor Organization. 2020. URL: https://www.ilo.org/moscow/news/WCMS_753125/lang--ru/index.htm

35 Young people developed pandemic fears. 2020. URL: https://urfu.ru/ru/news/35209/

${ }^{36}$ How COVID-19 and Other Events are Shaping Young People's Perceptions of the Future. Equitable Futures National Youth Poll 2020-2021. URL: https://www.equitablefutures.org/covid19/ 
up by the Soviet Union school along with the values of traditional Kazakhstani society. Therefore, young people treat education in a slightly different way than their peers from other countries, highlighting spiritual, non-material aspects of education and thereby suffering less from financial difficulties that they may face in future. For the majority of Kazakhstani students the main life goals, as well as the goals of studying at university are to become qualified specialists, achieve self-realization, career growth, create a family, get financial independence, success in business and travelling. Only $4 \%$ of students linked university studies with subsequent financial well-being. Most students see the value of education in the acquisition of a profession (44\%), education (33\%) and preparation for an independent life (15\%).

Nevertheless, Kazakhstan is a part of the global market, including education. This means that the problems of neoliberal school will sooner or later appear on this stage, too.

On one hand, the neoliberal governments of the world are striving to cope with the pandemic as quickly as possible, trying to balance the risks between the disease of society and the decline of economies, continuing "development" (read: survival) ${ }^{37}$. On the other hand, more and more scientisits all over the world are criticizing a neoliberal approach to education that does not teach young people to cope with life, but only provides them with a set of standardized,

\footnotetext{
37 McCloskey S. COVID-19 has Exposed NeoliberalDriven 'Development': How can Development Education Respond? Policy and practice. A development education review, 2020, pp. 174-185. URL: https://www.developmenteducationreview.com/issue/issue-30/covid19-has-exposed-neoliberal-driven- 'development'-howcan-development-education

${ }^{38}$ Gupta A. Value education in higher education. 2020. DOI https://doi.org/10.13140/RG.2.2.16787.84005
}

fragmented and rapidly aging skills and information $^{38}$.

It is worth noting that scientists had actively criticized neoliberalism in earlier times. An American scientist Michael Apple is convinced that neoliberalism undermines the foundations of the entire educational system. It led to the extreme commercialization and consumerization of the educational system. "Private education is undoubtedly good, but state one - is bad. Public schools seem to be "black holes" into which money is poured, and then they disappear without giving any results .... Schools are created for teachers and officials, not for "consumers." In a nutshell, for neoliberals the world is a huge supermarket. "Consumer choice" is a guarantor of democracy. Education is considered to be the same product as bread, cars or television"39.

The main disadvantages of neoliberalism in education are outlined as follows:

- new social inequality, as better-off young people can afford better education. "There has been a change in the main line in the goal-setting of educational process: now education is not a tool for overcoming social inequality, but, on the contrary, now it is a kind of factor of social differentiation through the provision of educational services at different level depending on the economic capabilities of the "customer" of education. This situation spurs the mechanism of "natural selection", within the framework of which new criteria of social justice are established" ${ }^{40}$.

\footnotetext{
${ }^{39}$ Apple M.W. Between Neoliberalism and Neoconservatism: Education and Conservatism in a Global Context. In: Torres, N.B. (Ed.) Globalization and Education: Critical Perspectives. Routledge, New York, 2000, pp. 5778. URL: https://longviewoneducation.org/wp-content/uploads/2018/01/BetweenNeoliberalismNewconservatism.pdf

${ }^{40}$ Khmelinin A. A. The Problem of Social Justice in Neoliberal Political Doctrine and Practice: A Theoretical Analysis. Scientific Yearbook of the Institute of Physics
} 
- standardization of educational process to the detriment of scientific schools and university traditions ${ }^{41}$,

- loss of cultural identity, a gap between education and national cultures in the conditions of globalization. As a result, education becomes incapable of performing the function of society reproduction.

- a decrease in the share of public investments in higher education establishments due to competition and university entrepreneurship, which leads to decrease in fundamental research and continuation of academic traditions,

- transformation of teachers and professors into sellers of educational services, and students into their clients, which significantly changes the architectonics of educational process, forcing teachers to adapt to the wishes of students, often to the detriment of their own education,

- symbolic replacement of the concept of "knowledge" with "information", fragmentation of this information and its presentation (sale) in the capacity of knowledge and skills to students, a rapid obsolescence of this information, the need to acquire knowledge (read: information) throughout entire life,

- absence of disciplinary, formative part and any other part necessary for life in the community, only money-making part is involved in the educational process.

The coronavirus pandemic, which suddenly spread all over the world, especially strongly in the most "educated" neoliberal countries, revealed inability of people to cope with it, lack of unity and solidarity. The widespread dissemination of fake information and mass

and Problems of the Ural Branch of the Russian Academy of Sciences, 2014, no. 3, pp. 159.

${ }^{41}$ Naletova I. Diversification of higher education: a challenge to universities. Higher Education in Russia, 2005, no. 5, pp. 39-45. ignorance in the fight against the virus showed the true education of people. And growing depressions and stresses reflect their disorientation and lack of spiritual basis in the value picture of the world.

In this regard, many scientists agree that a return to the past (neoliberal approach to education) can no longer be considered acceptable. The pandemic is no longer a temporary phenomenon, which will pass with the opening of universities and return of traditional education. The pandemic means abruption. Complete abruption with the past system and its educational approach.

"Coronavirus has brought the mighty of this world to their knees, and the world has slowed down like no one else could. Our minds are still tearing around, trying to find desperately a way to return to "normality", to sew future with the past without noticing abruption. But the gap has already happened. And in the midst of despair now we are given a chance to rethink the doomsday machine that we made for ourselves. There can be nothing worse than a return to normality. Pandemics have always forced people to break up with the past and re-imagine the world. The current pandemic is no exception. It is a portal, a gate that separates one world from another to come. We can walk through them, dragging behind us a dead weight of prejudice, hatred, greed, databases, empty ideas, poisoned rivers and dirty sky. Or we can - move forward light, without these belongings, ready to imagine another world and fight for it" 42 .

The gap is now more evident than ever. And necessary conditions are already being created for the formation of a new type of education -

\footnotetext{
${ }^{42}$ Roy A. Pandemic is a Portal. The Financial Times. 2020. URL: https://www.ft.com/content/10d8f5e8-74eb-11ea95fe-fcd274e920ca
} 
education that would take into account all mistakes of the old neoliberal school and learn the best lessons of the pandemic.

Among the trends in future education researchers identify the following:

1. A gradual decline in the level of commercialization of education sector and transformation of education into an intrinsic value. The pandemic gives a chance to turn our universities not into a gathering place for "intellectual technicians", but into a place where "people of thought, trained to think conceptually, holistically, transdisciplinary" will gather [19].

2. Striving to strengthen interdisciplinarity in the educational process and inclusion of discipline "impact on the planet" "Impact on the planet" should become an integral part of disciplinary knowledge, - says R. Gorur, - not as a six-week course in the first semester, but as a fundamental basis of any discipline. Focusing each discipline on understanding how decisions in this area affect society, with case studies assessing past contributions and effects, will substantiate and implement the abstract missions and visions supported by universities" [20].

3. Democratization of sphere of higher education through the widespread development of digitalization, expanding access to high-quality education for everyone (open resources, databases, courses, etc.).

4. Development of distant education with elements of interactivity and different forms of education.

5. Transformation of learners into knowledge producers and contributors to knowledge communities (based on networking communities).

6. Formation of new thinking based on criticism and creativity [21].

The pandemic has sharply raised the question of neoliberal or value price of education: studies have shown that young people around the world come to the conclusion that the cost of education today is determined not by the market, but by the spiritual needs of young people. In the face of growing anxiety, stress and depression, education can become a medicine, a panacea for young people from spiritual crisis. Accordingly, the future of education, its foundations, values and essence, and the possibility of neutralization of the consequences of COVID-19 pandemic with the help of new educational system depend on the efforts of modern scientists and educators around the world.

\section{Conclusions}

The crisis, which all world education was previously hidden in a latent form, today - has shown itself in the most impressive proportions. The pandemic did not create problems in higher education, but only exacerbated the existing ones to the extent, after which a return to "normality" will no longer be considered normal.

The neoliberal model of education, based on fierce competition, individualism and free trade, has failed. During pandemic this model has shown all its inconsistency. Developed societies with a strong neoliberal approach to the educational system are experiencing an acute crisis in economy, politics, as well as in the mental health of population. Young people from the USA, Europe, Australia, according to numerous studies, experience more stress and depression due to the capitalist market collapse happening in their eyes.

In their turn, developing societies classified as traditional, such as Kazakhstan, are less affected by pandemic in terms of mental wellbeing of young people, since not only market relations are important but other traditional and cultural values are appreciated by them.

It seems that a future prospect for the development of higher education in the world will be revised towards reducing the influence of neoliberalism and market, strengthening state 


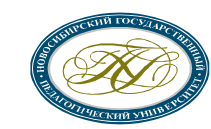

Science for Education Today

2022, vol. 12, issue 1 http://en.sciforedu.ru/

ISSN 2658-6762

control and financing in this area, humanization, humanitarization, fundamentalization and environmentalization of the sphere of higher education. Only in this form the higher education will continue to develop forward towards the creation of a fair, educated and culturally tolerant society.

\section{REFERENCES}

1. Centeno M. A., Cohen J. N. The arc of neoliberalism. Annual Review of Sociology, 2012, vol. 38 (1), pp. 317-340. DOI: https://doi.org/10.1146/annurev-soc-081309-150235

2. Hursh D., Henderson J. A. Contesting global neoliberalism and creating alternative futures. Discourse: Studies in the Cultural Politics of Education, 2011, vol. 32 (2), pp. 171-185. DOI: https://doi.org/10.1080/01596306.2011.562665

3. Peters M. A. Three forms of the knowledge economy: Learning, creativity and openness. British Journal of Educational Studies, 2010, vol. 58 (1), pp. 67-88. DOI: https://doi.org/10.1080/00071000903516452

4. Patrick F. Neoliberalism, the knowledge economy, and the learner: Challenging the inevitability of the commodified self as an outcome of education. International Scholarly Research Notices, 2013, vol. 2013, pp. 108705. DOI: https://doi.org/10.1155/2013/108705

5. Pan S. COVID-19 and the neo-liberal paradigm in higher education: Changing landscape. Asian Education and Development Studies, 2020, vol. 10 (2), pp. 322-335. DOI: https://doi.org/10.1108/aeds-06-2020-0129

6. Rhoades G., Slaughter S. Academic capitalism, managed professionals, and supply-side higher education. Social Text, 1997, vol. 51, pp. 9-38. DOI: https://doi.org/10.2307/466645

7. Marginson S. After globalization: Emerging politics of education. Journal of Education Policy, 1999, vol. 14 (1), pp. 19-31. DOI: https://doi.org/10.1080/026809399286477

8. Verdun A. European responses to globalization and financial market integration: perceptions of economic and monetary union in Britain, France and Germany. St. Martin's Press, New York, NY, 2000. DOI: https://doi.org/10.1057/9780230535824

9. Moos L. Neo-liberal governance leads education and educational leadership astray. In: Uljens M., Ylimaki R. (eds) Bridging Educational Leadership, Curriculum Theory and Didaktik. Educational Governance Research, 2017, vol. 5, pp. 151-180. Springer, Cham. DOI: https://doi.org/10.1007/978-3-319-58650-2_2

10. Peters M. Classical political economy and the role of universities in the new knowledge economy. Globalisation, Societies and Education, 2003, vol. 1 (2), pp. 153-168. DOI: https://doi.org/10.1080/1476772032000105483

11. Fumagalli A. Twenty theses on contemporary capitalism (cognitive biocapitalism). Journal of the Theoretical Humanities, 2011, vol. 16 (3), pp. 7-17. DOI: https://doi.org/10.1080/0969725X.2011.626555

12. Tsogas G. The commodity form in cognitive capitalism. Culture and Organization, 2012, vol. 18 (5), pp. 377-395. DOI: https://doi.org/10.1080/14759551.2012.728393

13. Olssen M., Peters M. Neoliberalism, higher education and the knowledge economy: From the free market to knowledge capitalism. Journal of Education Policy, 2005, vol. 20 (3), pp. 313-345. DOI: https://doi.org/10.1080/02680930500108718 
14. Phillips L., Ilcan S. Capacity-building: The neoliberal governance of development. Canadian Journal of Development Studies, 2004, vol. 25 (3), pp. 393-409. DOI: https://doi.org/10.1080/02255189.2004.9668985

15. Olssen M. Understanding the mechanisms of neoliberal control: Lifelong learning, flexibility and knowledge capitalism. International Journal of Lifelong Education, 2006, vol. 25 (3), pp. 213-230. DOI: https://doi.org/10.1080/02601370600697045

16. Giroux H. The Covid-19 pandemic is exposing the plague of neoliberalism. Praxis Educativa, 2020, vol. 24. DOI: https://doi.org/10.19137/praxiseducativa-2020-240202

17. Sharma A. The pandemic, race and the crisis of the neoliberal university: Study notes from lockdown London. Inter-Asia Cultural Studies, 2020, vol. 21 (4), pp. 645-655. DOI: https://doi.org/10.1080/14649373.2020.1832303

18. Schwartz K. D., Exner-Cortens D., McMorris C. A., Makarenko E., Arnold P., Van Bavel M., Williams S., Canfield R. COVID-19 and student well-being: Stress and mental health during returnto-school. Canadian Journal of School Psychology, 2021, vol. 36 (2), pp. 166-185. DOI: https://doi.org/10.1177/08295735211001653

19. Gibbs P. Transdisciplinary possibilities after the pandemic. Reimagining the new pedagogical possibilities for universities post-Covid-19. Educational Philosophy and Theory, 2020, vol. 52. DOI: https://doi.org/10.1080/00131857.2020.1777655

20. Gorur R. Course correction: Disciplines in the post-COVID world. Reimagining the new pedagogical possibilities for universities post-Covid-19. Educational Philosophy and Theory, 2020, vol. 52. DOI: https://doi.org/10.1080/00131857.2020.1777655

21. Burbules N. Lessons from the coronavirus: What we are learning about online learning Nicholas. Reimagining the new pedagogical possibilities for universities post-Covid-19. Educational Philosophy and Theory, 2020, vol. 52. DOI: https://doi.org/10.1080/00131857.2020.1777655

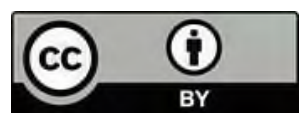

\footnotetext{
This is an open access article distributed under the Creative Commons Attribution License which permits unrestricted use, distribution, and reproduction in any medium, provided the original work is properly cited. (CC BY 4.0).
}

\section{The authors' stated contribution:}

Madina S. Ashilova Contribution of the co-author: collection of materials and initiation of research; definition of research methodology; analysis of research data.

Alibek S. Begalinov

Contribution of the co-author: collection of materials, preparation of the initial version of the text.

Kalimash K. Begalinova

Contribution of the co-author: the collection of materials; formulation of a scientific problem research and definition of the main directions of its decision; structuring and analysis of data. 


\section{Information about competitive interests:}

The authors claim that they do not have competitive interests.

\section{Information about the Authors}

\section{Madina Serikbekovna Ashilova}

$\mathrm{PhD}$, Associate Professor,

Departments of International Communications,

Abylai Khan Kazakh University of International Relations and Foreign

Languages, Muratbayev str., 200, 050001, Almaty, Kazakhstan.

ORCID ID: https://orcid.org/0000-0002-7634-7727

E-mail: madina.almatytv@mail.ru (Corresponding Author)

\section{Alibek Serikbekovich Begalinov}

$\mathrm{PhD}$, Professor-lecturer,

International Information Technology University,

34/1 Manas str., 050001, Almaty, Kazakhstan.

ORCID ID: https://orcid.org/0000-0001-7439-221X

E-mail: alibek557@inbox.ru

\section{Kalimash Kapsamarovna Begalinova}

Doctor of Philosophical Science, Professor,

Department of Religious Studies and Cultural Studies,

Al Farabi Kazakh National University,

71 Al-Farabi Ave., 050001, Almaty, Kazakhstan.

ORCID ID: https://orcid.org/0000-0001-5575-5142

E-mail: kalima910@mail.ru 


\title{
Смена неолиберальной концепции образования в эпоху COVID-19 и перспективы постковидного образования
}

\author{
М. С. Ашилова 㽞, А. С. Бегалинов ${ }^{2}$, К. К. Бегалинова ${ }^{3}$ \\ ${ }^{1}$ Казахский университет международных отношений и мировых языков имени Абылай Хана, \\ Алматы, Республика Казахстан \\ ${ }^{2}$ Международный университет информационных технологий, Алматы, Республика Казахстан \\ ${ }^{3}$ Казахский национальный университет им. Аль-Фараби, Алматы, Республика Казахстан
}

Проблема и цель. Авторами исследуется проблема иенностных изменений, происходящих в системе высшего образования. Пандемия COVID-19, распространившаяся в начале 2020 г., оказала серьезное влияние на сферу высшего образования. Она привела к необходимости пересмотра аксиологических основ современного образования. Целью настоящей статьи является анализ неолиберальной концепции высшего образования в современном мире и выявление трендов будущего, постковидного образования.

Методология. Материалами исследования выступили научные статьи зарубежных ученых за 2020 и 2021 годы, посвященные изучаемой тематике, а также соииологическое исследование, проведенное в Республике Казахстан и рассматривающее самочувствие и иенностные ориентиры студенческой молодежи в период пандемии COVID-19. Всего было опромено 1000 студентов из всех 14 регионов Казахстана. В выборке была сохранена основная доля учащихся (по гендеру, языку обучения, начиональности, курсам и специальностям). Исследование проводилось с применением приложения Google Forms. Основными методами исследования выступили контент-анализ научной литературы (более 40 зарубежных источников), а также анализ по итогам сочиологического опроса студентов в Казахстане.

Результаты. Авторами показано, что если в самом начале ученые обращали внимание на такие негативные аспекты пандемии, как слабая техническая оснащенность, сбои в работе интернета, неподготовленность педагогов и студентов к онлайн-обучению, рост студенческих долгов в связи с потерей работ и др., то вскоре стало ясно, что пандемия затронула не только внешнюю (экономическую, техническую) сторону образования, но и её самую суть.

Финансирование проекта: Исследование выполнено в рамках научно-исследовательского проекта ИРН АР09058341 «Трансформация ценностей казахстанской системы высшего образования в условиях поликультурного и глобализирующегося мира» и выполняется в рамках грантового финансирования Министерства образования и науки Республики Казахстан.

Библиографическая ссылка: Ашилова М. С., Бегалинов А. С., Бегалинова К. К. Смена неолиберальной концепции образования в эпоху COVID-19 и перспективы постковидного образования // Science for Education Today. - 2022. - T. 12, № 1. - C. 30-54. DOI: http://dx.doi.org/10.15293/2658-6762.2201.02

Автор для корреспонденции: Мадина С. Аиилова, madina.almatytv@mail.ru

(C) М. С. Аиилова, А. С. Бегалинов, К. К. Бегалинова, 2022 
Сегодня учеными подвергаются критическому анализу основания современного высшего образования - неолиберальнье концепции, которые в конце ХХ в. с развитием глобализации господствуют в разных странах мира. Показывается, что нынешний мировой образовательный кризис порождает не пандемия, а неучтенные негативные последствия глубокого проникновения в общество идей неолиберализма (рыночных отношений, неконтролируемой конкурениии, ослабления роли государства, слабой поддержки социальных секторов экономики и др.). Показано, что общества с развитой системой неолиберального высшего образования испытывают больше стресса, нежели развиваюшиеся, традиционные, как Казахстан, поскольку основу образования первых составляет преимущественно рынок и денежно-рыночные отношения, основу вторых - духовные, нематериальные цуенности образования.

Заключение. Исследуя перспективы постковидного образования на материале зарубежных ученых, авторы выдвигают идеи о необходимости отказа от неолиберализма в пользу большей гуманизации, фундаментализации и экологизации образования, усиления государственного контроля и финансирования. Только в таком виде возможно поступательное развитие, а не регресс сферы высшего образования после пандемии.

Ключевые слова: неолиберализм; пандемия COVID-19; высшее образование; философия образования; постковидное образование; самочувствие молодежи.

\section{СПИСОК ЛИТЕРАТУРЫ}

1. Centeno M. A., Cohen J. N. The Arc of Neoliberalism // Annual Review of Sociology. - 2012. Vol. 38 (1). - P. 317-340. DOI: https://doi.org/10.1146/annurev-soc-081309-150235

2. Hursh D., Henderson J. A. Contesting global neoliberalism and creating alternative futures // Discourse: Studies in the Cultural Politics of Education. - 2011. - Vol. 32 (2). - P. 171-185. DOI: https://doi.org/10.1080/01596306.2011.562665

3. Peters M. Three forms of the knowledge economy: learning, creativity and openness // British Journal of Educational Studies. - 2010. - Vol. 58 (1). - P. 67-88. DOI: https://doi.org/10.1080/00071000903516452

4. Patrick F. Neoliberalism, the Knowledge Economy, and the Learner: Challenging the Inevitability of the Commodified Self as an Outcome of Education // International Scholarly Research Notices. - 2013. - Vol. 2013. - P. 108705. DOI: https://doi.org/10.1155/2013/108705

5. Pan S. COVID-19 and the neo-liberal paradigm in higher education: changing landscape // Asian Education and Development Studies. - 2020. - Vol. 10 (2). - P. 322-335. DOI: https://doi.org/10.1108/aeds-06-2020-0129

6. Rhoades G., Slaughter S. Academic capitalism, managed professionals, and supply-side higher education // Social Text. - 1997. - Vol. 51. - P. 9-38. DOI: https://doi.org/10.2307/466645

7. Marginson S. After globalization: emerging politics of education // Journal of Education Policy. 1999. - Vol. 14 (1). - P. 19-31. DOI: https://doi.org/10.1080/026809399286477

8. Verdun A. European responses to globalization and financial market integration: perceptions of economic and monetary union in Britain, France and Germany. - St. Martin's Press, New York, NY, 2000. DOI: https://doi.org/10.1057/9780230535824

9. Moos L. Neo-liberal Governance Leads Education and Educational Leadership Astray // Bridging Educational Leadership, Curriculum Theory and Didaktik / Uljens M., Ylimaki R. (eds) Moos L. 


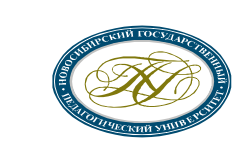

Science for Education Today

2022. Tom 12. № 1 http://sciforedu.ru/

ISSN 2658-6762

Educational Governance Research. - Springer, Cham. 2017. - Vol. 5. - P. 151-180. DOI: https://doi.org/10.1007/978-3-319-58650-2_2

10. Peters M. Classical political economy and the role of universities in the new knowledge economy // Globalisation, Societies and Education. - 2003. - Vol. 1 (2). - P. 153-168. DOI: https://doi.org/10.1080/1476772032000105483

11. Fumagalli A. Twenty theses on contemporary capitalism (cognitive biocapitalism) // Journal of the Theoretical Humanities. - 2011. - Vol. 16 (3). - P. 7-17. DOI: https://doi.org/10.1080/0969725X.2011.626555

12. Tsogas G. The commodity form in cognitive capitalism // Culture and Organization. - 2012. Vol. 18 (5). - P. 377-395. DOI: https://doi.org/10.1080/14759551.2012.728393

13. Olssen M., Peters M. Neoliberalism, higher education and the knowledge economy: from the free market to knowledge capitalism // Journal of Education Policy. - 2005. - Vol. 20 (3). - P. 313345. DOI: https://doi.org/10.1080/02680930500108718

14. Phillips L., Ilcan S. Capacity-building: the neoliberal governance of development // Canadian Journal of Development Studies. - 2004. - Vol. 25 (3). - P. 393-409. DOI: https://doi.org/10.1080/02255189.2004.9668985

15. Olssen M. Understanding the mechanisms of neoliberal control: lifelong learning, flexibility and knowledge capitalism // International Journal of Lifelong Education. - 2006. - Vol. 25 (3). P. 213-230. DOI: https://doi.org/10.1080/02601370600697045

16. Giroux H. The Covid-19 Pandemic Is Exposing the Plague of Neoliberalism // Praxis Educativa. 2020. - Vol. 24. DOI: https://doi.org/10.19137/praxiseducativa-2020-240202

17. Sharma A. The pandemic, race and the crisis of the neoliberal university: study notes from lockdown London // Inter-Asia Cultural Studies. - 2020. - Vol. 21 (4). - P. 645-655. DOI: https://doi.org/10.1080/14649373.2020.1832303

18. Schwartz K. D., Exner-Cortens D., McMorris C. A., Makarenko E., Arnold P., Van Bavel M., Williams S., Canfield R. COVID-19 and Student Well-Being: Stress and Mental Health during Return-to-School // Canadian Journal of School Psychology. - 2021. - Vol. 36 (2). - P. 166-185. DOI: https://doi.org/10.1177/08295735211001653

19. Gibbs P. Transdisciplinary possibilities after the pandemic // Reimagining the new pedagogical possibilities for universities post-Covid-19. - Educational Philosophy and Theory. - 2020. Vol. 52. DOI: https://doi.org/10.1080/00131857.2020.1777655

20. Gorur R. Course correction: Disciplines in the post-COVID world // Reimagining the new pedagogical possibilities for universities post-Covid-19. - Educational Philosophy and Theory. 2020. - Vol. 52. DOI: https://doi.org/10.1080/00131857.2020.1777655

21. Burbules N. Lessons from the coronavirus: What we are learning about online learning Nicholas // Reimagining the new pedagogical possibilities for universities post-Covid-19. - Educational Philosophy and Theory. - 2020. - Vol. 52. DOI: https://doi.org/10.1080/00131857.2020.1777655

Поступила: 30 сентября 2021 Принята: 10 января 2022 Опубликована: 28 февраля 2022 


\section{Заявленный вклад авторов:}

Мадина С. Ашилова: сбор материалов и инициация исследования; определение методологии исследования; анализ данных исследования.

Алибек С. Бегалинов: сбор материалов, подготовка начального варианта текста.

Калимаш К. Бегалинова: сбор материалов; постановка научной проблемы исследования и определение основных направлений ее решения; структурирование и анализ данных.

\section{Информация о конфликте интересов:}

Авторы заявляют об отсутствии конфликта интересов.

\section{Информация об авторах}

\section{Ашилова Мадина Серикбековна}

доктор философии $\mathrm{PhD}$, ассоциированный профессор, кафедра международных коммуникаций,

Казахский университет международных отношений и мировых языков имени Абылай Хана,

ул. Муратбаева, 200, 050001, Алматы, Республика Казахстан.

ORCID ID: https://orcid.org/0000-0002-7634-7727

E-mail: madina.almatytv@mail.ru

\section{Бегалинов Алибек Серикбекович}

доктор философии $\mathrm{PhD}$, профессор-лектор, кафедра медиакоммуникаций и истории Казахстана,

Международный университет информационных технологий, ул. Манаса 34/1, 050001, Алматы, Республика Казахстан.

ORCID ID: https://orcid.org/0000-0001-7439-221X

E-mail: alibek557@inbox.ru

\section{Бегалинова Калимаш Капсамаровна}

доктор философских наук, профессор, кафедра религиоведения и культурологии,

Казахский национальный университет им. Аль-Фараби, пр. Аль-Фараби, 71, 050001, Алматы, Республика Казахстан.

ORCID ID: https://orcid.org/0000-0001-5575-5142

E-mail: kalima910@mail.ru 


\title{
Иноязычное образование в ценностном становлении личности: анализ развития и современное измерение содержания проблемы (обзор)
}

\author{
М. В. Кузнецова घ ${ }^{1}$, Е. А. Пушкарёва ${ }^{1}$
}

${ }^{1}$ Новосибирский государственный педагогический университет, Новосибирск, Россия

Проблема и цель. В статье рассматривается проблема формирования образованной личности в межкультурном взаимодействии.

Цель исследования - анализ и обобщение исследовательских подходов к содержанию иноязычного образования в ценностном становлении личности.

Методология. Основа методологии заключается в сравнительном анализе и обобщении исследовательских трактовок и методологических подходов в контексте исследуемой проблемы.

Методологической основой исследования выступают основные принцииы философии образования, имеющей своим объектом образование во всех его иенностных, системных, проиессуальных и результативных характеристиках, учитывающих междисциплинарные факторы развития системы образования.

Сравнение проводится на основе обзора научной литературы по проблеме в области философии и истории образования, лингвокультурологии, педагогики.

Результаты. Авторами раскрывается современное измерение содержания проблемы формирования иноязычного образования в ценностном становлении личности в следующих основных ее контекстах: иноязычное образование в практике образования рассматривается в первую очередь как иелостно организованный педагогический прочесс обучения, воспитания личности; иноязычное образование - как проиесс интегративного развития языковой личности, способной к диалогу и коммуникации; иноязычное образование - как единый процесс познания мировой культуры.

Заключение. В заключении авторами обобщается основное содержание проблемы формирования иноязычного образования с акиентом на ценностное становление личности.

Ключевые слова: формирование образованной личности; межкультурное взаимодействие; иноязычное образование; ценностное становление личности; философия образования.

Библиографическая ссылка: Кузнецова М. В., Пушкарёва Е. А. Иноязычное образование в ценностном становлении личности: анализ развития и современное измерение содержания проблемы (обзор) // Science for Education Today. - 2022. - T. 12, № 1. - C. 55-75. DOI: http://dx.doi.org/10.15293/2658-6762.2201.03

口 Автор для корреспонденичи: Мария Владимировна Кузнецьва, golubeva19952001@yandex.ru

(C) М. В. Кузнецова, Е. А. Пушкарёва, 2022 


\section{Постановка проблемы}

Проблема иноязычного образования в становлении личности является актуальной в связи с интенсивным развитием глобального информационного общества и коммуникационных технологий [1-4]. В настоящее время складывается проблема неоднозначного отношения членов информационного общества к использованию цифровых технологий в образовании [5-10]; исследуется многовекторное воздействие информационного развития на личность в образовательной среде [11-14]; выявляются пути совершенствования обучения языку в виртуальном образовательном пространстве [15-18]. Указанные тенденции показывают необходимость российского общества в специалистах, способных использовать иностранный язык в профессиональных, образовательных целях как внутри своей страны, так и на международном уровне.

Целью данной работы был анализ различий в содержании трактовок иноязычное образование. Авторы предположили, что различие подходов связано с интегративным содержанием данного понятия и акцентом исследователей на отдельных аспектах такого содержания. Были рассмотрены философское, культурологическое, педагогическое содержание и

\footnotetext{
${ }^{1}$ Наливайко Н. В. Философия образования. Некоторые проблемы формирования концепции. - Новосибирск, 2000. - 140 с.; Паршиков В. И. Философские основания современного образования: монография. - Новосибирск: ГЦРО, 2001. - 264 с.; Майер Б. О. Когнитивные аспекты современной философии отечественного образования: монография. - Новосибирск: Издво СО РАН, 2006. - 276 с.; Пушкарева Е. А., Наливайко Н. В. Формирование отечественной системы образования в современных условиях // Философия образования. - 2010. - № 1. - С. 24-29.

${ }^{2}$ Гершунский Б. С. Философия образования: учебное пособие для студентов высших и средних педагогических учебных заведений. - М.: Московский психолого-социальный институт, 1998. - 432 с.
}

выявлены соответствующие исследовательские акценты и современная специфика исследуемых проблем в данной области.

\section{Методология исследования}

Методологической основой исследования выступает философия образования ${ }^{1}$. Философия образования имеет своим объектом образование во всех его ценностных, системных, процессуальных и результативных характеристиках, учитывающих, междисциплинарные, внешние, фоновые параметры и факторы, так или иначе влияющие на функционирование и развитие сферы образования ${ }^{2}$.

Основные положения философии образования были разработаны такими учеными, как Б. С. Гершунский ${ }^{3}$, В. В. Краевский ${ }^{4}$, Н. В. Наливайко ${ }^{5}$. Научные труды данных исследователей посвящены философским и теоретическим основаниям отечественной системы образования, что создает фундаментальную (онтологическую, гносеологическую, аксиологическую) основу для изучения развития личности в процессе иноязычного образования.

Б. С. Гершунский ${ }^{6}$ показывает, что философия образования - это самостоятельная область научных знаний, фундаментом которых являются не столько общефилософские

\footnotetext{
${ }^{3}$ Там же.

${ }^{4}$ Краевский В. В. Методология педагогики: пособие для педагогов-исследователей. - Чебоксары: Изд-во Чуваш. ун-та, 2001. - 244 с.

${ }^{5}$ Наливайко Н. В., Паршиков В. И. Философия образования как объект комплексного исследования. - Новосибирск: Изд-во СО РАН, 2002. - 192 с.

${ }^{6}$ Гершунский Б. С. Философия образования: учебное пособие для студентов высших и средних педагогических учебных заведений. - М.: Московский психолого-социальный институт, 1998. - 432 с.
} 
учения, обращенные к образованию, сколько объективные закономерности развития собственно образовательной сферы во всех аспектах ее функционирования.

Предметом философии образования как науки являются наиболее общие, фундаментальные основания функционирования и развития образования, определяющие, в свою очередь, критериальные основы оценки тоже достаточно общих, междисциплинарных теорий, законов, закономерностей, категорий, понятий, терминов, принципов, постулатов, правил, методов, гипотез, идей и фактов, относящихся к образованию7.

Положения культурологического подхода, выдвинутые М. С. Каган ${ }^{8}$, И. А. Колесниковой ${ }^{9}$, дают возможность для анализа и обобщения проблем формирования иноязычного образования через систему таких понятий, как культура, культурные образцы, нормы, идеалы, ценности.

М. С. Каган ${ }^{10}$ подчеркивает, что в философском анализе культура предстает как такая форма бытия, которая образуется человеческой деятельностью, охватывая:

- качества самого человека как субъекта деятельности - качества сверхприродные, т. е. такие, которые, опираясь на данные ему от природы возможности, формируются в ходе становления человечества и воссоздаются каждый раз вновь в ходе становления индивида;

- те способы деятельности, которые не врождены человеку, - ни виду, ни индивиду, но которые им изобретаются, совершенствуются и передаются из поколения в поколение,

\footnotetext{
${ }^{7}$ Гершунский Б. С. Философия образования: учебное пособие для студентов высших и средних педагогических учебных заведений. - М.: Московский психолого-социальный институт, 1998. - 432 с.

${ }^{8}$ Каган М. С. Философия культуры. - СПб,1996. 415 c.
}

благодаря обучению, образованию, воспитанию;

- многообразие предметов - материальных, духовных, художественных, - в которых опредмечиваются процессы деятельности, которые становятся «второй природой», творимой из материала «первой», подлинной природы для того, чтобы удовлетворять сверхприродные, специфически человеческие потребности и служить передатчиком этого человеческого начала другим людям;

- вторичные способы деятельности, служащие уже не опредмечиванию, а распредмечиванию тех человеческих качеств, которые хранятся в предметном бытии культуры;

- вновь человек, вторая роль которого в культуре обусловливается тем, что в процессе распредмечивания он растет, меняется, обогащается, развивается, становится продуктом культуры;

- связь процессов опредмечивания и распредмечивания с общением участвующих в них людей как особым аспектом человеческой деятельности и, соответственно, феноменом культуры.

Определяя понятие «педагогическая культура», И. А. Колесникова акцентирует внимание на социально-исторически обусловленном контексте и результате проявления вовне внутренней специфики субъекта (носителя), рождающего педагогическое качество реальности. Автор отмечает, что именно в ориентации на творение человеческого образа, а не на добросовестное усвоение содержания учебного знания кроются подлинные истоки гуманизации современного образования и его

\footnotetext{
${ }^{9}$ Колесникова И. А. Педагогическая реальность в зеркале межпарадигмальной рефлексии. - СПб.: СПбГУПМ, 1999. - 242 с.

${ }^{10}$ Каган М. С. Философия культуры. - СПб,1996. $415 \mathrm{c}$.
} 
гуманитарная сущность. И. А. Колесникова подчеркивает, что пафос педагогической деятельности, ее центральное назначение следует искать в поле человеческих смыслов, постоянно ориентируясь на получение не столько формального, предметного, сколько сугубо человеческого результата.

Определение лингвистических оснований проблемы формирования иноязычного образования в становлении личности позволяет выявить особенности языковой личности, ее содержания, определить специфику ее лингвистических компонентов культуры. Так, Л. В. Щерба отмечал особое значение изучения языка для формирования образа человека в образовательном процессе: «Сравнивая детально разные языки, мы разрушаем ту иллюзию, к которой нас приучает знание лишь одного языка, - иллюзию, будто существуют незыблемые понятия, которые одинаковы для всех времен и для всех народов. В результате получается освобождение мысли из плена слова, из плена языка и придание ей истинной диалектической научности» ${ }^{11}$.

\section{Результаты исследования}

Раскроем содержание проблемы формирования иноязычного образования в следующих основных ее контекстах:

- иноязычное образование как целостно организованный педагогический процесс обучения, воспитания личности;

- иноязычное образование как процесс интегративного развития языковой личности, способной к диалогу и коммуникации;

\footnotetext{
${ }^{11}$ Цит. по: Бекасова Е. Ю. Личностные характеристики студентов в условиях формирования профессионального билингвизма: автореф. дис. ... канд. психол. наук. - М., 2017. - 27 с.

12 Ветчинова М. Н. Теория и практика иноязычного образования в отечественной педагогике второй половины XIX - начала XX века: автореф... дис. д-ра. пед.

(C) 2011-2022 Science for Education Today
}

- иноязычное образование как единый процесс познания мировой культуры.

Иноязычное образование как целостно организованный педагогический процесс обучения, воспитания личности

Иноязычное образование - это целостно организованный педагогический процесс обучения, воспитания и развития учащихся в рамках предмета «Иностранный язык», который способствует становлению опыта творческой деятельности, духовному развитию личности обучающихся и формированию их культуры (М. Н. Ветчинова) $)^{12}$.

Акцент в данном определении направлен на средства и содержание предмета, на основе которого происходит процесс научения знанию иного языка.

Иноязычное личностно ориентированное образование - единый процесс обучения, воспитания и развития целостной личности и субъектности учащегося содержанием и средствами предмета «Иностранный язык» (Е. В. Борзова $)^{13}$.

Иноязычное образование - целостный педагогический процесс обучения, воспитания и развития обучающихся содержанием и средствами предмета «Иностранный язык» (И. П. Селезнева, И. А. Майер [19, с. 115]).

Как правило, исследователями в данном направлении раскрываются этапы и уровни такого образования в соответствии с уровневой структурой системы образования: дошкольное, общеобразовательное, дополнительное образование, профессиональное образование.

\footnotetext{
наук. - M., 2009. - C. 3-4. URL: https://www.elibrary.ru/item.asp?id=15950134

${ }^{13}$ Борзова Е. В. Иноязычное личностно ориентированное образование на старшей ступени средней школы: автореф. дисс. ... д-ра пед. наук. - Санкт-Петербург, 2008. - C. $10 . \quad$ URL: https://elibrary.ru/item.asp?id=15867365
} 
Школьное иноязычное образование является средством приобщения обучаемых к иноязычной культуре, содействует формированию опыта межкультурного общения в процессе организованного овладения его содержанием (Е. Я. Григорьева) ${ }^{14}$.

Специфика раннего иноязычного образования, способствующая формированию культурного самоопределения младшего школьника, заключается в возможности становления ребенка путем его вхождения в культуру, обеспечения у него восприятия адекватной современному уровню знаний картины мира и его интеграции в систему мировой и национальной культур (Е. А. Исаев) ${ }^{15}$.

Начальное развивающее иноязычное образование - это:

- способ введения ученика начальной школы в образовательную область «Филология», создающей функциональный базис для развития достижений дошкольного возраста и подготовки к овладению иностранным языком на второй ступени общего школьного образования;

- процесс духовно-нравственного, когнитивного и коммуникативного развития и саморазвития младшего школьника, овладевающего иностранным языком, формирования его нравственных ценностей, эмоционально-

14 Григорьева Е. Я. Проектирование содержания школьного иноязычного образования в современных условиях: автореф. дис. ... д-ра пед. наук / Нижегор. гос. лингвист. ун-т им. Н.А. Добролюбова. - Нижний Новгород, 2014. - C. 14. URL: https://elibrary.ru/item.asp?id=30406598

${ }^{15}$ Исаев Е. А. Культурное самоопределение младшего школьника в процессе раннего иноязычного образования: автореф. дис. ... канд. пед. наук / Елецкий государственный университет им. И. А. Бунина. - Елец, 2011. - C. $7 . \quad$ URL: https://www.elibrary.ru/item.asp?id=19349062

${ }^{16}$ Никитенко 3. Н. Теория и технология развивающего иноязычного образования в начальной школе: автореф. дис. ... д-ра пед. наук. - Нижний Новгород,

(C) 2011-2022 Science for Education Today волевой сферы, учебной деятельности и становления иноязычной речевой деятельности как нового средства взаимодействия с окружающим многоязычным и поликультурным миром (3. Н. Никитенко) ${ }^{16}$.

Дополнительное профессиональное иноязычное образование - подсистема дополнительного образования взрослых, методология которого реализует комплекс принципов, при этом ведущим из них является концепция диалога культур, и отвечает современной ситуации в России - сближению образования с экономикой (Л. В. Журавлева $)^{17}$.

Иноязычное образование - процесс овладения совокупностью межкультурных, языковых и профессионально-коммуникативных знаний и умений, результатом которого является иноязычная компетентность будущих специалистов (И. В. Касьянова) ${ }^{18}$.

Иноязычное лингвистическое образование - это процесс и результат подготовки специалистов высшей квалификации, обладающих совокупностью компетенций, систематизированных знаний и практических навыков, позволяющих решать теоретические и практические задачи по профилю подготовки для педагогической, переводческой, дипломатической и другой деятельности, требующей знания иностранного языка (Л. А. Дейкова) ${ }^{19}$.
2011.
C.
14.
URL: https://elibrary.ru/item.asp?id=19361637

17 Журавлева Л. В. Развитие гуманитарного потенциала педагога в дополнительном иноязычном образовании: автореф. дисс. ... д-ра пед. наук. - М., 2011. C. 16. URL: https://elibrary.ru/item.asp?id=19355867

18 Касьянова И. В. Педагогическое управление иноязычным образованием будущих юристов в процессе профессиональной подготовки: автореф. дисс. ... канд. пед. наук. - Магнитогорск, 2005. - C. 9. URL: https://elibrary.ru/item.asp?id=15831943

19 Дейкова Л. А. Становление и развитие иноязычного лингвистического образования в вузах России (историко-теоретический аспект): автореф. дис. ... канд. пед. наук / Ульян. гос. пед. ун-т им. И.Н. Ульянова. - 
Отдельное внимание исследователей уделяется вопросам истории формирования профессиональной подготовки учителей [20; 21] и специалистов иностранного языка [22; 23] в ретроспективе развития педагогического образования [24-26]. Исторический контекст проблемы связан с необходимостью поиска ответов на современные проблемы развития.

Проблемы же современного этапа развития исследователи связывают:

- с выбором новых средств и методов преподавания ${ }^{20}$ [27; 28];

- с выбором содержания учебного предмета в соответствии с целью и возрастным психолого-педагогическим подходом в образовании ${ }^{21}$ [29];

- с выявлением специфики формирования иноязычной компетенции ${ }^{22}$ [30] в процессе научения иностранному языку [31].

\section{Иноязычное образование как процесс} интегративного развития языковой личности, способной к диалогу и коммуникации

Иноязычное образование есть интегративное образование личности, имеющее системную ориентацию и сложную структуру и выступающее как совокупность межкультурных, языковых и профессионально-коммуникативных знаний и умений, в основе которых

\footnotetext{
Ульяновск, 2011. - C. 10. URL: https://elibrary.ru/item.asp?id=30357367

${ }^{20}$ Стратегия индивидуализации высшего иноязычного профессионально-ориентированного образования: подходы, методы, технологии / Н. И. Алмазова, А. В. Рубцова, Е. А. Крылова и др. - Санкт-Петербург: Санкт-Петербургский политехнический университет Петра Великого, 2020. - 128 с. ISBN 978-57422-6895-6

URL: https://elibrary.ru/item.asp?id=42488222

${ }^{21}$ Преемственность в иноязычном образовании: проблемы и перспективы / Е. В. Бессонова, О. А. Блинова, Е. А. Исакович и др.; Волгоградский государственный институт искусств и культуры. - Волгоград: Волгоградское научное издательство, 2016. -
}

лежит концепт развития языковой личности, способной к продуктивной коммуникации, предрасположенной к диалогу, взаимопониманию людей (Е. П. Звягинцева, Н. Г. Кондрахина [32, с. 113]).

Иноязычное образование - процесс овладения совокупностью межкультурных, языковых и профессионально-коммуникативных знаний и умений, в основе которых лежит концепт развития личности, способной к продуктивной коммуникации, к диалогу культур, взаимопониманию людей, более глубокому познанию психологии и культуры других народов (И. В. Касьянова $)^{23}$.

Интеграция содержания осуществляется вокруг образа языковой личности, ее качеств, формируемых посредством языка.

Под иноязычным филологическим образованием, т. е. видом филологического образования, в центре которого - обучение иностранным языкам, мы предлагаем понимать культуроцентристское/социо- и поликультурное становление личности, которое происходит благодаря изучению языка и явлений, связанных со сферами (ино-/многоязычной) коммуникации, познанию культур стран изучаемых языков (и через их призму - своей культуры) за

\footnotetext{
154 c. ISBN 978-5-00072-181-0 URL: https://elibrary.ru/item.asp?id=26105887

22 Иноязычная профессиональная компетентность в поликультурном образовании: коллективная научная монография / А. П. Лиферов, Л. П. Костикова, О. Н. Исаева и др. - Рязань: Рязанский ИздательскоПолиграфический Дом «ПервопечатникЂ», 2015. 120 c. ISBN 978-5-00050-042-2 URL: https://elibrary.ru/item.asp?id=24894452

${ }^{23}$ Касьянова И. В. Педагогическое управление иноязычным образованием будущих юристов в процессе профессиональной подготовки: автореф. дисс. ... канд. пед. наук. - Магнитогорск, 2005. - C. 9. URL: https://elibrary.ru/item.asp?id=15831943
} 
счёт изучения языковых продуктов этих культур, вхождению обучающегося в социокультурную, поликультурную среду и участие в диалоге культур в ходе иноязычной коммуникативной деятельности; формирование компетенций в рамках научной области «Филология», способствующих выполнению различных видов филологической (учебной, научной и практической) деятельности, а также развитие качеств, характеристик, свойств индивида, способствующих социализации в современном глобальном, информационно-коммуникативном обществе средствами предметов филологического цикла (в нашем случае имеется в виду иноязычная/инокультурная филология) (А. А. Колесников [33, с. 63].

Проблемы современного этапа развития исследователи связывают с современной спецификой:

- социокультурного и поликультурного становления личности [34];

- становления личностных качеств, формируемых посредством языка [35; 36];

- личностной социализации в современном глобальном обществе [37];

- информационно-коммуникативного влияния на развитие личности $[11 ; 17]$.

Полиязычное образование - это целенаправленный, организуемый, нормируемый триединый процесс обучения, воспитания и развития индивида как полиязыковой личности на основе одновременного овладения несколькими языками как «фрагментом» социально значимого опыта человечества, воплощенного в языковых знаниях и умениях, языковой и речевой деятельности, а также в эмоционально-ценностном отношении к языкам и культурам [38, с. 8].
Под ино- и многоязычным филологическим образованием мы предлагаем понимать комплексное образование, ориентированное:

1) на социо-, меж- и поликультурное становление личности, которое происходит благодаря:

- изучению языков и явлений, связанных со сферами ино-, многоязычной, межкультурной коммуникации, познанию культур стран изучаемых языков и переосмыслению своей культуры через их призму за счет изучения текстовых/дискурсивных продуктов этих культур,

- вхождению обучающегося в социокультурную, поликультурную среду,

- участию в диалоге культур за счет иноязычной коммуникативной деятельности;

2) на формирование у обучающегося компетенций, которые сопрягаются с научной областью «Филология» и способствуют выполнению различных видов филологической (учебной, научной и практической) деятельности;

3) на развитие качеств, характеристик, свойств индивида, способствующих его социализации в современном глобальном, информационно-коммуникативном и поликультурном обществе средствами предметов филологического цикла (имеется в виду иноязычная/инокультурная филология).

Вышеописанное позволяет сделать вывод: в русле личностно ориентированного подхода наиболее обобщенной образовательной целью иноязычного филологического образования является становление социо-/поли/межкультурной личности как плюрилингвального субъекта непрерывного развития (А. А. Колесников [33 с. 11]). 


\section{Иноязычное образование как единый} процесс познания мировой культуры

Иноязычное образование - это образование, осуществляемое посредством иностранного языка как инструмента познания мировой культуры, нацеленное на становление личности обучающегося (В. Н. Карташова) $)^{24}$.

Кроме того, Б. С. Гершунский отмечает, что только на основе реальной оценки собственной образовательной сферы и сравнения уровня образования с международным уровнем высших образовательных достижений любая страна может рассчитывать на полноправное и многоаспектное партнерство в мировом сообществе, конкурентоспособность экономики, уважение к духовным, культурным и ментальным традициям и ценностям ее народов.

Поликультурное воспитание - это целенаправленный гуманистический процесс освоения культурообразовательных ценностей, предусматривающий развитие навыков межличностного взаимодействия в ситуации плюралистической культурной среды, адаптацию к иным культурным ценностям (Н. В. Кагуй $)^{25}$.

Интеграция и акцент в данном измерении содержания проблемы осуществляется вокруг понимания ценностного компонента культуры ${ }^{26}$ [39], нацеленности на формирование единой картины мира в ее разнообразии.

\footnotetext{
${ }^{24}$ Карташова В. Н. Формирование лингвогуманитарной культуры в процессе подготовки учителя к раннему иноязычному образованию: автореф... дис. дpa. пед. наук. - Елец., 2003. - C. 13. URL: https://www.elibrary.ru/item.asp?id=15778377

${ }^{25}$ Кагуй Н. В. Поликультурное воспитание детей дошкольного возраста в процессе билингвального образования: автореферат диссертации на соискание ученой степени кандидата педагогических наук. - Екатеринбург, 2004. - 23 с. URL: https://elibrary.ru/item.asp?id=15889266
}

В данном контексте лингвистическое образование представляет собой специально организованную образовательную среду, опосредующую процесс такого вхождения в инокультуру, при котором эта культура начинает трансформироваться в ценностно-смысловые составляющие образа мира человека, расширяя его жизненное пространство, предопределяя тем самым возможности трансформации образа жизни (в том числе и профессионального самоопределения) (Н. Н. Истомина) ${ }^{27}$.

Проблемы современного этапа развития исследователи связывают с проблемами формирования:

- толерантности и эмпатии [34];

- единства и многообразия культурных ценностей $[40 ; 41]$; - глобализации [42] и интернационализации культурного развития, формирования национальной идентичности [43].

Отдельным направлением исследования становится проблема возникновения, становления и развития так называемого мультикультурного образования [44] в мировом образовательном процессе. Его отдельными аспектами называют бикультурное (билингвизм) ${ }^{28}$ и поликультурное языковое образование.

26 Культуроведческие аспекты языкового образования. - М.: Еврошкола, 1998. - 165 с. ISBN 5-93285001-9 URL: https://elibrary.ru/item.asp?id=26073747

${ }^{27}$ Истомина Н. Н. Формирование мотивационной готовности к профессиональному самоопределению в лингвистическом образовании: автореферат диссертации на соискание ученой степени кандидата педагогических наук. - Томск, 2006. - C. 8. URL: https://elibrary.ru/item.asp?id=15913844

${ }^{28}$ Круглякова, Т. А. Проблемы изучения билингвизма: книга для чтения. - Санкт-Петербург: Златоуст, 2014. - 278 c. - ISBN 978-5-86547-000-0 URL: https://elibrary.ru/item.asp?id=30667813 
Иноязычное образование в контексте бикультурного и поликультурного развития личности

Е. М. Верещагин и В. Г. Костомаров ввели такой термин, как «лингвострановедение», и определили межкультурное общение как «адекватное взаимопонимание двух участников коммуникативного акта, принадлежащих к разным национальным культурам». Они показали, что «поведенческий быт входит в речевые формулы, т. е. речевой этикет тесно связан с культурой» ${ }^{29}$. Исследователи отмечают, что в процессе формирования культуры иноязычного общения необходимо вырабатывать в сознании студентов понятия о новых предметах и явлениях, не находящих аналогии ни в их родной культуре, ни в их родном языке ${ }^{30}$.

Билингвальное образование - это целенаправленная педагогически организованная социализация индивида, осуществляемая в условиях естественного или искусственного билингвизма, в процессе которого обеспечивается освоение обучающимися образцов и ценностей мировой культуры средствами родного и иностранного языков, когда иностранный язык выступает в качестве способа постижения мира специальных знаний, усвоения культурно-исторического и социального опыта различных стран и народов. Билинг-

\footnotetext{
${ }^{29}$ Игнатенко И. И. Формирование культуры иноязычного делового общения студентов в системе высшего гуманитарного образования: монография. - М.: МПГУ, 2018. - С. 73.

30 Там же.

${ }^{31}$ Ширин А. Г. Билингвальное образование в отечественной и зарубежной педагогике: автореферат диссертации на соискание ученой степени доктора педагогических наук. - Великий Новгород, 2007. - С. 18. URL: https://elibrary.ru/item.asp?id=15846275
}

вальное образование включает в себя билингвальное обучение и поликультурное воспитание (А. Г. Ширин) $)^{31}$.

Л. В. Щерба ${ }^{32}$ полагал, что «под двуязычием подразумевается способность тех или иных групп населения объясняться на двух языках», с уточнением: «Так как язык является функцией социальных группировок, то быть двуязычным значит принадлежать одновременно к двум таким различным группировкам». Он рассматривает билингвизм не только с лингвистической, но и с социокультурной точки зрения.

Поликультурное образование как социальное явление представляет собой процесс обучения и воспитания, предусматривающий привитие студентам системы разнообразных и взаимодействующих культурных ценностей. Результатом поликультурного образования является формирование личности, способной к адекватному взаимодействию с представителями других культурных сообществ, сохраняющей и приумножающей (благодаря переосмыслению) ее собственную культуру ${ }^{33}$.

Поликультурность как свойство личности представляет собой качество, основанное на синтезе толерантности, эмпатии и переоценки собственной культуры; поликультурность может и должна формироваться у обучающихся в ходе поликультурного образования ${ }^{34}$.

32 Щерба Л. В. Языковая система и речевая деятельность / под ред. Л. Р. Зиндера, М. И. Матусевич. - 4е изд. - Ленинград : ЛКИ, 2008. 432 с.

${ }^{33}$ Межкультурное иноязычное образование: лингводидактические стратегии и тактики / Е. Г. Тарева, А. В. Анненкова, Е. С. Дикова и др. - М.: ООО "Издательская группа "Логос", 2014. - С. 30. URL: https://elibrary.ru/item.asp?id=23628853

${ }^{34}$ Межкультурное иноязычное образование: лингводидактические стратегии и тактики / Е. Г. Тарева, 
Поликультурное образование следует понимать как процесс управляемого присвоения системы культурных ценностей, присущих различным общностям, формирование и развитие на основе особых черт личности обучающихся как субъектов культуры (толерантность, эмпатия, способность к переоценке своей культуры); эти черты проявляют себя в отношении человека к поликультурному миру, ценностных ориентациях и поведении ${ }^{35}$.

Межкультурный подход в иноязычном образовании

Межкультурный подход - это учет в процессе обучения обязательного взаимодействия равноправных контактирующих языковых и концептуальных систем участников коммуникации - представителей двух лингвосоциумов - родного и иного ${ }^{36}$.

Целесообразность - направленность на формирование вторичной языковой личности (И. И. Халеева), обладающей языковой и концептуальной картинами мира родного и иного лингвосоциума и осознающей собственную универсальную сущность как культурно-исторического субъекта ${ }^{37}$

Межкультурное образование включает следующие аспекты: страноведческую и культурно-специфическую информацию, а также лингвистический компонент, развивающий в индивидууме способность к адекватному поведению в определенных ситуациях и имеющих межкультурное значение (Г. В. Телегина [45, с. 27]).

\section{Заключение}

В заключение раскроем выявленное в данном исследовании современное измерение содержания проблемы формирования иноязычного образования в ценностном становлении личности в следующих основных ее контекстах.

\section{1. Иноязычное образование в практике} образования рассматривается в первую очередь как иелостно организованный педагогический процесс обучения, воспитания личности в рамках учебного предмета «Иностранный язык».

Акцент в данном измерении содержания проблемы направлен на средства и содержание учебного предмета, на основе которого происходит процесс научения.

Как правило, исследователями в данном направлении в соответствии с уровневой структурой системы образования раскрываются этапы и уровни такого образования: дошкольное, общеобразовательное, дополнительное образование, профессиональное образование.

Проблемы же современного этапа развития исследователи связывают:

- с выбором новых средств и методов преподавания;

- с выбором содержания учебного предмета в соответствии с целью и возрастным психолого-педагогическим подходом в образовании;

- с выявлением специфики формирования иноязычной компетенции в процессе научения иностранному языку.

\footnotetext{
А. В. Анненкова, Е. С. Дикова и др. - М.: ООО "Издательская группа "Логос", 2014. - С. 33. URL: https://elibrary.ru/item.asp?id=23628853
}

\author{
35 Там же. - C. 34. \\ 36 Там же. - С. 48. \\ ${ }^{37}$ Там же. - C. 53.
}


2. Иноязычное образование как прочесс интегративного развития языковой личности, способной к диалогу и коммуникации.

Иноязычное образование в данном контексте есть интегративное образование личности, имеющее системную ориентацию и сложную структуру и выступающее как совокупность межкультурных, языковых и профессионально-коммуникативных знаний и умений, в основе которых лежит концепт развития языковой личности, способной к продуктивной коммуникации, предрасположенной к диалогу.

Интеграция и акцент в данном измерении содержания проблемы осуществляется вокруг образа языковой личности, ее качеств, формируемых посредством языка.

В данном контексте основное содержание вкладывается в такие аспекты становления личности, как культуроцентристское, социокультурное и поликультурное становление личности. Что предполагает развитие таких качеств, характеристик, свойств индивида, которые бы способствовали его социализации в современном глобальном, информационнокоммуникативном обществе.

Проблемы современного этапа развития исследователи связывают с современной спецификой:

- социокультурного и поликультурного становления личности;

- становления личностных качеств, формируемых посредством языка;

- личностной социализации в современном глобальном обществе;
- информационно-коммуникативного влияния на развитие личности.

3. Иноязычное образование как единый прочесс познания мировой культуры.

Иноязычное образование в данном контексте - это образование, осуществляемое посредством иностранного языка как инструмента познания мировой культуры, нацеленное на становление личности обучающегося.

Интеграция и акцент в данном измерении содержания проблемы осуществляется вокруг понимания ценностного компонента культуры, нацеленности образования на формирование единой картины мира в ее разнообразии.

В данном контексте лингвистическое образование представляет собой специально организованную образовательную среду, опосредующую процесс такого вхождения в инокультуру.

Проблемы современного этапа развития исследователи связывают с проблемами формирования:

- толерантности и эмпатии;

- единства и многообразия культурных ценностей;

- глобализации и интернационализации культурного развития, формирования национальной идентичности.

Отдельным направлением исследования становится проблема возникновения, становления и развития так называемого мультикультурного образования в мировом образовательном процессе.

\section{СПИСОК ЛИТЕРАТУРЫ}

1. Kobylarek A. Post-pandemic challenges for learning communities // Journal of Education Culture and Society. - 2021. - Vol. 12 (1). - P. 5-11. DOI: https://doi.org/10.15503/jecs2021.1.5.11 
2. Kobylarek A., Plavčan P., \& Amini Golestani T. Educational priorities in a post pandemic world // Journal of Education Culture and Society. - 2021. - Vol. 12 (2). - P. 5-11. DOI: https://doi.org/10.15503/jecs2021.2.5.11

3. Pushkarev Yu. V., Pushkareva E. A. Philosophical interpretation of knowledge and information: Knowledge value and information diversity in modern communication // XLinguae. - 2018. Vol. 11 (3). - P. 176-184. DOI: https://doi.org/10.18355/XL.2018.11.03.17

4. Pushkarev Y. V., Pushkareva E. A. Communication foundation for intellectual culture: tendencies of contemporary development // XLinguae. - 2019. - Vol. 12 (4). - P. 212-218. DOI: https://doi.org/10.18355/XL.2019.12.04.18

5. Barnett R. The risk of digital reason: Fearing interactive technologies in higher education // Reimagining the new pedagogical possibilities for universities post-Covid-19. - Educational Philosophy and Theory. - 2020. - Vol. 52. DOI: https://doi.org/10.1080/00131857.2020.1777655

6. Chou T.-L., Wu J.-J., Tsai C.-C. Research Trends and Features of Critical Thinking Studies in ELearning Environments // Journal of Educational Computing Research. - 2019. - Vol. 57 (4). P. 1038-1077. DOI: https://doi.org/10.1177/0735633118774350

7. Cuadrado D., Salgado J. F., Moscoso S. Personality, intelligence, and counterproductive academic behaviors: A meta-analysis // Journal of Personality and Social Psychology. - 2021. - Vol. 120 (2). P. 504-537. DOI: https://doi.org/10.1037/psP0000285

8. Hanafy S. M., Jumaa M. I., Arafa M. A. A comparative study of online learning in response to the coronavirus disease 2019 pandemic versus conventional learning // Saudi Medical Journal. 2021. - Vol. 42 (3). - P. 324-331. DOI: https://doi.org/10.15537/smj.2021.42.3.20200741

9. Petrovic F., Murgas F., Kralik R. Happiness in Czechia during the COVID-19 pandemic // Sustainability. - 2021. - Vol. 13 (19), - P. 1-17. DOI: https://doi.org/10.3390/su131910826

10. Pavlíkova M., Sirotkin A., Kralik R., Petrikovicova L., Garcia M. J. How to keep university active during COVID-19 pandemic: Experience from Slovakia // Sustainability. - 2021. - Vol. 13 (18). P. 14. DOI: https://doi.org/10.3390/su131810350

11. Caskurlu S., Richardson J. C., Maeda Y., Kozan K. The qualitative evidence behind the factors impacting online learning experiences as informed by the community of inquiry framework: A thematic synthesis // Computers and Education. - 2021. - Vol. 165 (2). - P. 104111. DOI: https://doi.org/10.1016/j.compedu.2020.104111

12. Chen Ch.-Ch., Wang N.-Ch., Tu Y.-F., Lin H. J. Research trends from a decade (2011-2020) for information literacy in higher education: Content and bibliometric mapping analysis // Proceedings of the Association for Information Science and Technology. - 2021. - Vol. 58 (1). DOI: https://doi.org/10.1002/pra2.435

13. Luo H., Li G., Feng Q., Yang Y., Zuo M. Virtual reality in K-12 and higher education: A systematic review of the literature from 2000 to 2019 // Journal of Computer Assisted Learning. - 2021. Vol. 37 (3). DOI: https://doi.org/10.1111/jcal.12538

14. Oliveira G., Teixeira J. G., Torres A., Morais C. An exploratory study on the emergency remote education experience of higher education students and teachers during the COVID-19 pandemic // British Journal of Educational Technology. - 2021. - Vol. 5 (4). - P. 1357-1376. DOI: https://doi.org/10.1111/bjet.13112

15. Arco-Tirado J. L., Fernández-Martín F. D., Hervás-Torres M. Evidence-based peer-tutoring program to improve students' performance at the university // Studies in Higher Education. - 2020. Vol. 45 (11). - P. 2190-2202. DOI: https://doi.org/10.1080/03075079.2019.1597038 
16. Azizi M., Pavlíková M., Slobodová Nováková K., Baghana J. The differential effects of dynamic assessment versus coded focused feedback on the process writing of EFL learners // European Journal of Contemporary Education. - 2021. - Vol. 10 (2). - P. 273-284. DOI: https://doi.org/10.13187/ejced.2021.2.273

17. Charters M., Murphy C. Taking art school online in response to COVID 19: From rapid response to realising potential // International Journal of Art and Design Education. - 2021. - Vol. 40 (4). DOI: https://doi.org/10.1111/jade.12384

18. Khonamri F., Kralik R., Vitecková M., Petrikovicová L.Self-assessment and EFL literature students' oral reproduction of short stories // European Journal of Contemporary Education. - 2021. Vol. 10 (1). - P. 77-88. DOI: https://doi.org/10.13187/ejced.2021.1.77

19. Селезнева И. П., Майер И. А. Метапредметное проектирование магистерских программ в сфере иноязычного образования: монография. - Красноярск, 2021. - 172 с. URL: https://elibrary.ru/item.asp?id=45787226

20. Локтюшина Е. А. Из истории становления отечественной теории и практики языкового образования в профессиональных целях // Бизнес. Образование. Право. - 2012. - № 4. - С. $221-$ 225. https://www.elibrary.ru/item.asp?id=18137722

21. Саламатина И. И., Ковалёва Е. А. Основные подходы к анализу истории отечественного иноязычного образования // Российский научный журнал. - 2015. - № 1. - С. 114-120. URL: https://www.elibrary.ru/item.asp?id=23300854

22. Воевода Е. В., Жилина Л. В. Некоторые аспекты иноязычной подготовки специалистов в отечественном профессиональном образовании: история и современность // Среднее профессиональное образование. - 2015. - № 12. - C. 58-60. URL: https://www.elibrary.ru/item.asp?id=25512410

23. Колесников А. А. Становление концепции профориентационного обучения иностранным языкам в системе филологического образования: история и перспективы // Иностранные языки в высшей школе. - 2018. - № 2. - C. 67-76. URL: https://www.elibrary.ru/item.asp?id=35411025

24. Клименко Т. К., Левченко О. Ю. Подготовка учителей иностранного языка в ретроспективе развития педагогического образования (XIX - начало XX века) // Ученые записки забайкальского государственного университета. - 2016. - Т. 11, № 5. - С. 48-52. DOI: https://doi.org/10.21209/2542-0089-2016-11-5-48-52 URL: https://www.elibrary.ru/item.asp?id $=28859188$

25. Левченко О. Ю. Иностранные языки в профессиональной подготовке специалистов (XIXв.) // Профессиональное образование в России и за рубежом. - 2020. - № 2. - С. 191196. URL: https://www.elibrary.ru/item.asp?id=44211243

26. Лифанцев И. Б. Генезис иноязычной подготовки в советский период // Педагогический журнал. - 2019. - Т. 9, № 1-1. - С. 620-630. DOI: https://doi.org/10.34670/AR.2019.44.1.094 URL: https://www.elibrary.ru/item.asp?id=38513205

27. Воробьева Е. И. Информатизация иноязычного образования: основные направления и перспективы: монография. - Архангельск: Поморский ун-т, 2011. ISBN 978-5-88086-952-7 URL: https://elibrary.ru/item.asp?id=20033979

28. Обдалова О. А. Иноязычное образование в XXI веке в контексте социокультурных и педагогических инноваций. - Томск: Национальный исследовательский Томский государственный университет, 2014. - 180 с. ISBN 978-5-7511-2259-1 URL: https://elibrary.ru/item.asp?id=24787834 
29. Ярославова Е. Н. Концепция непрерывного профессионально-ориентированного иноязычного образования как условие самореализации будущего специалиста высшей квалификации: монография. - Челябинск: Издательский центр ЮУрГУ, 2010. - 27 с. ISBN 978-5-69604303-6 URL: https://elibrary.ru/item.asp?id=20082481

30. Багатеева А. О., Ахметзянова Г. Н. Теоретико-методологические основы развития иноязычной коммуникативной компетентности студентов технического вуза в условиях модульного обучения: монография. - Казань: Казанский национальный исследовательский технологический университет, 2014. - 121 с. ISBN 978-5-7882-1725-3 URL: https://elibrary.ru/item.asp?id=29994794

31. Сидакова Н. В. Профессионально-компетентностная модель иноязычного обучения: пути формирования в условиях многоуровневого образования: монография. - Владикавказ: Издво СОГУ, 2012. - 179 с. ISBN 978-5-8336-0715-2 URL: https://elibrary.ru/item.asp?id=20063086

32. Звягинцева Е. П., Кондрахина Н. Г. Поликультурный компонент профессионально ориентированного иноязычного образования будущих экономистов // Иностранные языки в экономических вузах России. - $2013 . \quad-\quad$ С. 111-120. URL: https://www.elibrary.ru/item.asp?id=23722528

33. Колесников А. А. Научные основы профориентационного обучения иностранным языкам в системе непрерывного филологического образования: моногр.; Ряз. гос. ун-т им. С. А. Есенина. - Рязань, 2016. - 428 c. URL: https://elibrary.ru/item.asp?id=26590482

34. Byram M., Porto M., Wagner M. Ethical issues in teaching for intercultural citizenship in world / Foreign Language Education // TESOL Quarterly. - 2021. - Vol. 55 (1). - P. 308-321. DOI: https://doi.org/10/1002/tesq.3008

35. Hlas A. C. Grand challenges and great potential in foreign language teaching and learning // Foreign Language Annals. - 2018. - Vol. 51 (1). - P. 46-54. DOI: https://doi.org/10.1111/flan.12317

36. Александрова О. М., Биболетова М. 3. Содержание языкового образования в полиэтническом российском социуме. - М.: Изд-во "Экон-Информ", 2014. - 145 с. ISBN 978-5-99062441-2 URL: https://elibrary.ru/item.asp?id=25708267

37. Peker H., Regalla M. Making exemption the exception, not the rule: Inclusion of all students in foreign language education // Foreign Language Annals. - 2021. - Vol. 54 (1). - P. 73-90. DOI: https://doi.org/10.11111/flan.12513

38. Калижанова А. Н., Ибраева Б. М., Ишмуратова М. Ю., Бобеш Р. С., Павленко Е. Г. Инновации и лидерство в иноязычном образовании: коллективная монография. - Караганды: РИО «Болашак-Баспа», 2017. - 152 c. URL: https://elibrary.ru/item.asp?id=35165962

39. Телегина Г. В., Штыкова Н. В., Золотавина Ф. Г. Языковое образование и интеграция культур; Тюменский государственный университет. - Тюмень: Тюменский государственный университет, 2003. - 114 c. ISBN 5-88081-341-X URL: https://elibrary.ru/item.asp?id=19767563

40. Тараскина Я. В. Иноязычное образование в Германии: история и современность // Ученые записки забайкальского государственного университета. - 2013. - № 6. - С. 184-192. URL: https://www.elibrary.ru/item.asp?id=21087874

41. Соболь Н. В. Генезис и развитие культурологических ориентиров современного иноязычного образования в истории гуманитарного знания // Известия российской академии образования. - 2011. - № 1. - С. 26-38. URL: https://www.elibrary.ru/item.asp?id=16269322

42. Федюковский А. А. Лингвистическое образование в условиях социально-экономических преобразований // Ученые записки Санкт-Петербургского университета управления и экономики. - 2015. - № 4. - C. 84-90. URL: https://www.elibrary.ru/item.asp?id=24836603 
43. Петрова Н. Е. Языковое образование в истории России как фактор формирования национальной идентичности // Нижегородское образование. - 2013. - № 1. - С. 70-75. URL: https://www.elibrary.ru/item.asp?id=20149139

44. Еныгин Д. В. История возникновения мультикультурного образования в мировой педагогике // Педагогика и просвещение. - 2018. - № 3. - С. 12-17. DOI: https://doi.org/10.7256/2454-0676.2018.3.23368 URL: https://www.elibrary.ru/item.asp?id=36323351

45. Телегина Г. В. Языковое образование и интеграция культур. - Тюмень: Тюменский государственный университет, 2003. - 114 c. URL: https://elibrary.ru/item.asp?id=19767563

Поступила: 03 Ноября 2021 Принята: 10 января 2022 Опубликована: 28 февраля 2022

\section{Заявленный вклад авторов:}

Кузнецова Мария Владимировна: сбор материалов, подготовка начального варианта текста; постановка научной проблемы исследования, анализ данных исследования.

Пушкарёва Елена Александровна: определение методологии исследования; определение основных направлений решения проблемы; структурирование и обобщение данных; общее руководство исследованием.

\section{Информация о конфликте интересов:}

Авторы заявляют об отсутствии конфликта интересов.

\section{Информация об авторах}

\section{Кузнецова Мария Владимировна}

старший преподаватель кафедры теории и методики дошкольного образования, Новосибирский государственный педагогический университет.

Аспирант кафедры права и философии,

Новосибирский государственный педагогический университет.

630126, г. Новосибирск, ул. Вилюйская, 28,

ORCID ID: http://orcid.org/0000-0002-1959-6671

E-mail: golubeva19952001@yandex.ru

\section{Пушкарёва Елена Александровна}

доктор философских наук, профессор кафедры права и философии, Новосибирский государственный педагогический университет.

Профессор кафедры психологии и педагогики, Институт естественных и социально-экономических наук, Новосибирский государственный педагогический университет.

ORCID ID: http://orcid.org/0000-0002-1857-6783

E-mail: pushkarev73@mail.ru 


\title{
Foreign language education and value formation of a personality: Analysis of contemporary trends and developments (review)
}

\author{
Maria V. Kuznetsova $\square^{1}$, Elena A. Pushkareva ${ }^{1}$ \\ ${ }^{1}$ Novosibirsk State Pedagogical University, Novosibirsk, Russian Federation
}

Abstract

Introduction. The article considers personal development through intercultural communication. The purpose of the study is to analyze and summarize approaches to researching the content of foreign language education with the main focus on the value formation of a personality.

Materials and Methods. The research methodology comprises a comparative analysis and generalization of research interpretations and methodological approaches to intercultural language teaching and learning.

The study follows the basic principles of philosophy of education, which considers education in its value, system, procedural and productive characteristics, taking into account the interdisciplinary factors of the development of the education system.

The comparative analysis is based on scholarly literature on the problem in the fields of philosophy and history of education, linguistics, cultural and education studies.

Results. The authors reveal the modern dimension in studying the content of foreign language education with the main focus on the value-based formation of a personality in the following main contexts: education;

(1) foreign language education as a holistic process of teaching and learning and moral

(2) foreign language education as an integrated process of developing a linguistic personality capable of dialogue and communication;

(3) foreign language education as an integrated process of learning world culture.

Conclusions. In conclusion, the authors summarize the main content of foreign language education with an emphasis on value formation of a personality.

Keywords

Formation of an educated personality; Intercultural interaction; Foreign language education; Value formation of personality; Philosophy of education.

\section{For citation}

Kuznetsova M. V., Pushkareva E. A. Foreign language education and value formation of a personality: Analysis of contemporary trends and developments (review). Science for Education Today, 2022, vol. 12 (1), pp. 55-75. DOI: http://dx.doi.org/10.15293/2658-6762.2201.03

曰@ Corresponding Author: Maria Vladimirovna Kuznetsova, golubeva19952001@yandex.ru

(C) Maria V. Kuznetsova, Elena A. Pushkareva, 2022 


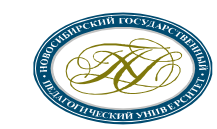

Science for Education Today

2022, vol. 12, issue 1 http://en.sciforedu.ru/

ISSN 2658-6762

\section{REFERENCES}

1. Kobylarek A. Post-pandemic challenges for learning communities. Journal of Education Culture and Society, 2021, vol. 12 (1), pp. 5-11. DOI: https://doi.org/10.15503/jecs2021.1.5.11

2. Kobylarek A., Plavčan P., \& Amini Golestani T. Educational priorities in a post pandemic world. Journal of Education Culture and Society, 2021, vol. 12 (2), pp. 5-11. DOI: https://doi.org/10.15503/jecs2021.2.5.11

3. Pushkarev Yu. V., Pushkareva E. A. Philosophical interpretation of knowledge and information: Knowledge value and information diversity in modern communication. XLinguae, 2018, vol. 11 (3), pp. 176-184. DOI: https://doi.org/10.18355/XL.2018.11.03.17

4. Pushkarev Y. V., Pushkareva E. A. Communication foundation for intellectual culture: Tendencies of contemporary development. XLinguae, 2019, vol. 12 (4), pp. 212-218. DOI: https://doi.org/10.18355/XL.2019.12.04.18

5. Barnett R. The risk of digital reason: Fearing interactive technologies in higher education. Reimagining the new pedagogical possibilities for universities post-Covid-19. Educational Philosophy and Theory, 2020, vol. 52. DOI: https://doi.org/10.1080/00131857.2020.1777655

6. Chou T.-L., Wu J.-J., Tsai C.-C. Research trends and features of critical thinking studies in elearning environments. Journal of Educational Computing Research, 2019, vol. 57 (4), pp. 10381077. DOI: https://doi.org/10.1177/0735633118707356

7. Cuadrado D, Salgado J. F, Moscoso S. Personality, intelligence, and counterproductive academic behaviors: A meta-analysis. Journal of Personality and Social Psychology, 2021, vol. 120 (2), pp. 504-537. DOI: https://doi.org/10.1037/psP0000285

8. Hanafy S. M., Jumaa M. I., Arafa M. A. A comparative study of online learning in response to the coronavirus disease 2019 pandemic versus conventional learning. Saudi Medical Journal, 2021, vol. 42 (3), pp. 324-331. DOI: https://doi.org/10.15537/smj.2021.42.3.20200741

9. Petrovic, F., Murgas, F., Kralik, R. Happiness in Czechia during the COVID-19 pandemic. Sustainability, 2021, vol. 13 (19), pp. 1-17. DOI: https://doi.org/10.3390/su131910826

10. Pavlíkova M., Sirotkin A., Kralik R., Petrikovicova L., Garcia M. J. How to keep university active during COVID-19 pandemic: Experience from Slovakia. Sustainability, 2021, vol. 13 (18), pp. 14. DOI: https://doi.org/10.3390/su131810350

11. Caskurlu S., Richardson J. C., Maeda Y., Kozan K. The qualitative evidence behind the factors impacting online learning experiences as informed by the community of inquiry framework: A thematic synthesis. Computers \& Education, 2021, vol. 165 (2), pp. 104111. DOI: https://doi.org/10.1016/j.compedu.2020.104111

12. Chen Ch.-Ch., Wang N.-Ch., Tu Y.-F., Lin H. J. Research trends from a decade (2011-2020) for information literacy in higher education: Content and bibliometric mapping analysis. Proceedings of the Association for Information Science and Technology, 2021, vol. 58 (1). DOI: https://doi.org/10.1002/pra2.435

13. Luo H., Li G., Feng Q., Yang Y., Zuo M. Virtual reality in K-12 and higher education: A systematic review of the literature from 2000 to 2019. Journal of Computer Assisted Learning, 2021, vol. 37 (3). DOI: https://doi.org/10.1111/jcal.12538

14. Oliveira G., Teixeira J. G., Torres A., Morais C. An exploratory study on the emergency remote education experience of higher education students and teachers during the COVID-19 pandemic. British Journal of Educational Technology, 2021, vol. 5 (4), pp. 1357-1376. DOI: https://doi.org/10.1111/bjet.13112 


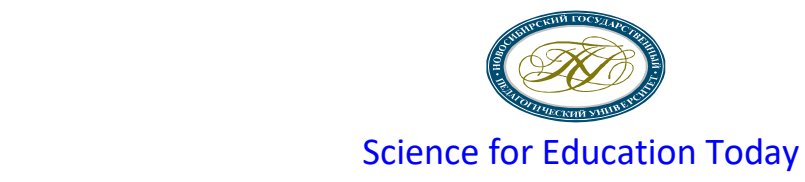

2022, vol. 12, issue $1 \quad$ http://en.sciforedu.ru/

ISSN 2658-6762

15. Arco-Tirado J. L., Fernández-Martín F. D., Hervás-Torres M. Evidence-based peer-tutoring program to improve students' performance at the university. Studies in Higher Education, 2020, vol. 45 (11), pp. 2190-2202. DOI: https://doi.org/10.1080/03075079.2019.1597038

16. Azizi M., Pavlíková M., Slobodová Nováková K., Baghana J. The differential effects of dynamic assessment versus coded focused feedback on the process writing of EFL learners. European Journal of Contemporary Education, 2021, vol. 10 (2), pp. 273-284. DOI: https://doi.org/10.13187/ejced.2021.2.273

17. Charters M., Murphy C. Taking art school online in response to COVID 19: From rapid response to realising potential. International Journal of Art \& Design Education, 2021, vol. 40 (4). DOI: https://doi.org/10.1111/jade. 12384

18. Khonamri F., Kralik R., Vitecková M., Petrikovicová L.Self-assessment and EFL literature students' oral reproduction of short stories. European Journal of Contemporary Education, 2021, vol. 10 (1), pp. 77-88. DOI: https://doi.org/10.13187/ejced.2021.1.77

19. Selezneva I. P., Mayer I. A. Metasubject design of master's programs in the field of foreign language education: monograph. Krasnoyarsk, 2021. 172 p. (In Russian) URL: https://elibrary.ru/item.asp?id=45787226

20. Loktyushina E. A. From the history of the formation of the national theory and practice of language education for professional purposes. Business. Education. Right, 2012, no. 4, pp. 221-225. (In Russian) URL: https://www.elibrary.ru/item.asp?id=18137722

21. Salamatina I. I., Kovaleva E. A. The main approaches to the historical analysis of language teaching in Russia. Russian Scientific Journal, 2015, no. 1, pp. 114-120. (In Russian) URL: https://www.elibrary.ru/item.asp?id=23300854

22. Voevoda E. V., Zhilina L. V. Some aspects of specialists' foreign language training in the domestic vocational education: History and modernity. Secondary Vocational Education, 2015, no. 12, pp. 58-60. (In Russian) URL: https://www.elibrary.ru/item.asp?id=25512410

23. Kolesnikov A. A. Concept formation of vocation-guided foreign languages teaching in the system of philological education: History and prospects. Foreign Languages in High School, 2018, no. 2, pp. 67-76. (In Russian) URL: https://www.elibrary.ru/item.asp?id=35411025

24. Klimenko T. K., Levchenko O. Yu. Training of foreign language teachers in the retrospective of the development of pedagogical education (XIX - early XX century). Scientific notes of the Trans-

Baikal State University, 2016, vol. 11 (5), pp. 48-52. (In Russian) DOI: https://doi.org/10.21209/2542-0089-2016-11-5-48-52 URL: https://www.elibrary.ru/item.asp?id=28859188

25. Levchenko O. Yu. Foreign languages in the professional training of specialists (XIX century). Vocational Education in Russia and Abroad, 2020, no. 2, pp. 191-196. (In Russian) URL: https://www.elibrary.ru/item.asp?id=44211243

26. Lifantsev I. B. The foreign languages training genesis in the soviet period. Pedagogical Journal, 2019, vol. 9 (1-1), pp. 620-630. (In Russian) DOI: https://doi.org/10.34670/AR.2019.44.1.094 URL: https://www.elibrary.ru/item.asp?id=38513205

27. Vorobyova E. I. Informatization of foreign language education: main directions and prospects: monograph. Arkhangelsk: Pomorsky Univ., 2011. ISBN 978-5-88086-952-7 (In Russian) URL: https://elibrary.ru/item.asp?id=20033979

28. Obdalova O. A. Foreign language education in the XXI century in the context of socio-cultural and pedagogical innovations. Tomsk: National Research Tomsk State University, 2014. 180 p. ISBN 978-5-7511-2259-1 (In Russian) URL: https://elibrary.ru/item.asp?id=24787834 


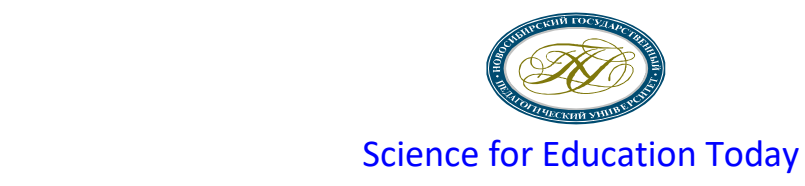

2022, vol. 12, issue 1 http://en.sciforedu.ru/

ISSN 2658-6762

29. Yaroslavova E. N. The concept of continuous professionally-oriented foreign language education as a condition for self-realization of a future highly qualified specialist: monograph. Chelyabinsk: SUSU Publishing Center, 2010. 27 p. ISBN 978-5-696-04303-6 (In Russian) URL: https://elibrary.ru/item.asp?id=20082481

30. Bagateeva A. O., Akhmetzyanova G. N. Theoretical and methodological foundations of the development of foreign language communicative competence of technical university students in the conditions of modular training: monograph. Kazan: Kazan National Research Technological University, 2014. 121 p. ISBN 978-5-7882-1725-3 (In Russian) URL: https://elibrary.ru/item.asp?id=29994794

31. Sidakova N. V. Professional competence model of foreign language teaching: ways of formation in conditions of multilevel education: monograph. Vladikavkaz: Publishing House of SOGU, 2012. 179 p. ISBN 978-5-8336-0715-2 (In Russian) URL: https://elibrary.ru/item.asp?id=20063086

32. Zvyagintseva E. P., Kondrakhina N. G. Multicultural component of professionally oriented foreign language education of future economists. Foreign Languages in Economic Universities of Russia, 2013, pp. 111-120. (In Russian) URL: https://www.elibrary.ru/item.asp?id=23722528

33. Kolesnikov A. A. Scientific foundations of career-oriented teaching of foreign languages in the system of continuous philological education: monograph. Ryazan, Ryazan State University named after S.A. Yesenin, 2016. 428 p. (In Russian) URL: https://elibrary.ru/item.asp?id=26590482

34. Byram M., Porto M., Wagner M. Ethical issues in teaching for intercultural citizenship in world / Foreign Language Education. TESOL Quarterly, 2021, vol. 55 (1), pp. 308-321. DOI: https://doi.org/10/1002/tesq.3008

35. Hlas A. C. Grand challenges and great potential in foreign language teaching and learning. Foreign Language Annals, 2018, vol. 51 (1), pp. 46-54. DOI: https://doi.org/10.1111/flan.12317

36. Alexandrova O. M., Biboletova M. Z. The content of language education in polyethnic Russian society. Moscow: Limited Liability Company "Ekon-Inform Publishing House", 2014. 145 p. ISBN 978-5-9906244-1-2 (In Russian) URL: https://elibrary.ru/item.asp?id=25708267

37. Peker H., Regalla M. Making exemption the exception, not the rule: Inclusion of all students in foreign language education. Foreign Language Annals, 2021, vol. 54 (1), pp. 73-90. DOI: https://doi.org/10.11111/flan.12513

38. Kalizhanova A. N., Ibraeva B. M., Ishmuratova M. Y., Bobesh R. S., Pavlenko E. G. Innovations and leadership in foreign language education: a collective monograph. Karaganda: RIO "Bolashak-Baspa", 2017. 152 p. (In Russian) URL: https://elibrary.ru/item.asp?id=35165962

39. Telegina G. V., Shtykova N. V., Zolotavina F. G. Language education and integration of cultures. Tyumen: Tyumen State University, 2003. 114 p. ISBN 5-88081-341-X (In Russian) URL: https://elibrary.ru/item.asp?id=19767563

40. Taraskina Ya. V. Foreign languages teaching in Germany: Past and present. Scientific notes of the Trans-Baikal State University, 2013, no. 6, pp. 184-192. (In Russian) URL: https://www.elibrary.ru/item.asp?id=21087874

41. Sobol' N. V. Culturological guidelines genesis and development for the modern foreign language education in the humanities history. Proceedings of the Russian Academy of Education, 2011, no. 1, pp. 26-38. (In Russian) URL: https://www.elibrary.ru/item.asp?id=16269322

42. Fedyukovsky A. A. Linguistic education in the conditions of social and economic transformations. Scientific notes of the St. Petersburg University of Management and Economics, 2015, no. 4, pp. 84-90. (In Russian) URL: https://www.elibrary.ru/item.asp?id=24836603 


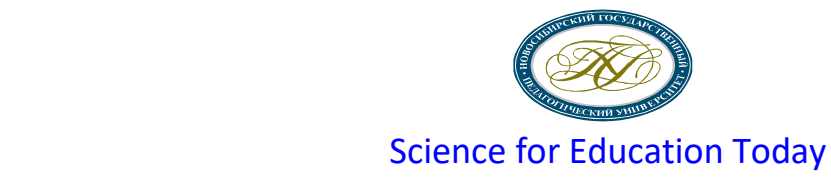

2022, vol. 12, issue 1 http://en.sciforedu.ru/

ISSN 2658-6762

43. Petrova N. E. Language education in the history of Russia as a factor of formation of national identity. Nizhny Novgorod Education, 2013, no. 1, pp. 70-75. (In Russian) URL: https://www.elibrary.ru/item.asp?id=20149139

44. Enygin D. V. The history of the emergence of multicultural education in world pedagogy. Pedagogy and Enlightenment, 2018, no. 3, p. 12-17. (In Russian) DOI: https://doi.org/10.7256/2454-0676.2018.3.23368 URL: https://www.elibrary.ru/item.asp?id=36323351

45. Telegina G. V. Language education and integration of cultures. Tyumen: Tyumen state University, 2003. 114 p. (In Russian) URL: https://elibrary.ru/item.asp?id=19767563

Submitted: 03 November 2021 Accepted: 10 January 2022 Published: 28 February 2022

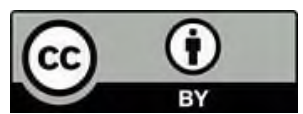

This is an open access article distributed under the Creative Commons Attribution License which permits unrestricted use, distribution, and reproduction in any medium, provided the original work is properly cited. (CC BY 4.0).

\section{The authors' stated contribution:}

Maria Vladimirovna Kuznetsova

Contribution of the co-author: collection of materials, preparation of the initial version of the text; formulation of the scientific problem of research, analysis of research data.

Elena Aleksandrovna Pushkareva

Contribution of the co-author: definition of research methodology; definition of the main directions of solving the problem; structuring and generalization of data; general management of the study.

\section{Information about competitive interests:}

The authors claim that they do not have competitive interests.

\section{Information about the Authors}

\section{Maria Vladimirovna Kuznetsova}

Post-Graduate Student,

Department of Law and Philosophy,

Novosibirsk State Pedagogical University;

Senior Lecturer,

Department of preschool education theory and methodology,

Novosibirsk State Pedagogical University,

Vilyuyskaya St., 28, 630126, Novosibirsk, Russian Federation.

ORCID ID: http://orcid.org/0000-0002-1959-6671

E-mail: golubeva19952001@yandex.ru (Corresponding Author) 


\section{Elena Aleksandrovna Pushkareva}

Doctor of Philosophical Sciences, Professor,

Law and Philosophy Department,

Novosibirsk State Pedagogical University,

Professor,

Department of Psychology and Pedagogy,

Institute of Natural and Socio-Economic Sciences,

Novosibirsk State Pedagogical University,

Vilyuyskaya St., 28, 630126, Novosibirsk, Russian Federation.

ORCID ID: http://orcid.org/0000-0002-1857-6783

E-mail: pushkarev73@mail.ru 


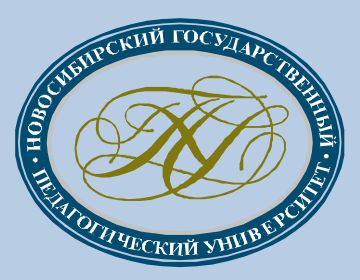

www.sciforedu.ru

\author{
МАТЕМАТИКА \\ И ЭКОНОМИКА \\ ДЛЯ ОБРАЗОВАНИЯ
}

\title{
MATHEMATICS AND ECONOMICS FOR EDUCATION
}




\title{
Развитие soft skills у старшеклассников с применением цифровых инструментов
}

\author{
А. С. Рылеева ${ }^{1}$, Е. А. Хомутникова ${ }^{1}$, С. В. Еманова $\square^{1}$ \\ ${ }^{1}$ Курганский государственный университет, Курган, Россия
}

Проблема и цель. В статье представлены обзор исследования по проблеме развития soft skills y cтаршеклассников, результаты исследования развития уровня универсальных компетеничии у старшеклассников и поиск подходов по развитию универсальных компетенций у старшеклассников через использование иифровых инструментов. Цель исследования - выявить уровень развития soft skills у старшеклассников и обосновать реализачию практико-ориентированных прочедур в условиях иифровой образовательной средьл.

Методология. В исследовании для определения уровня развития таких универсальных компетениий у девятиклассников, как эмочиональный интеллект и навыки самоконтроля, были применены общенаучные методы: анализ, синтез, обобщение теоретических источников по проблеме; диагностические методы: тест «Оиенка самоконтроля в общении» (М. Снайдер) и Методика Томаса-Килманна, в ходе которой были выявлены типы поведения старшеклассников в ситуачии конфликта в классе. Авторами были разработаны практико-ориентированные процедуры, направленные на развитие самоконтроля, навыков конструктивного межличностного взаимодействия, эмочионального интеллекта, что осуществлялось через использование образовательных платформ «Лифт в будущее» и Learnis.ru.

Результаты. Основные результаты заключаются в выявлении проблем в развитии soft skills у опрошенных 400 9-классников. Авторы определили инвариантные (низкий уровень рефлексии, отсутствие мотивачии на саморазвитие, неготовность меняться) и вариативные трудности, которые усложняют процесс успешного развития soft skills у девятиклассников и связаны с индивидуально-типологическими чертами личности: неуверенность в себе, завышенный уровень притязаний, эмочиональная незрелость, повышенная утомляемость. В ходе исследования были вылялены низкий уровень развития эмоционального интеллекта у 50 \% опрошенных, низкий уровень навыков сотрудничества у 75 \% опрошенных. Авторы представили содержание практикоориентированных процедур с применением цифровых инструментов, в ходе реализачии которых показатели универсальных компетениий у старшеклассников повысились. Авторы отмечают необходимость использовать как групповые формы работы, так и индивидуальные, учитывать инвариантные и вариативные трудности, препятствующие успешному развитию soft skills. Aвторы обобщают термин «цифровая грамотность», раскрывая его основное содержание.

Библиографическая ссылка: Рылеева А. С., Хомутникова Е. А., Еманова С. В. Развитие soft skills у старшеклассников с применением цифровых инструментов // Science for Education Today. - 2022. T. 12, № 1. - C. 77-98. DOI: http://dx.doi.org/10.15293/2658-6762.2201.04

曰目 Автор для корреспонденичи: Еманова Светлана Владимировна, sv_етап@таil.ru

(C) А. С. Рылеева, Е. А. Хомутникова, С. В. Еманова, 2022 
Заключение. Авторы указывают, что применение цифровых инструментов в ходе работы способствовало поддержанию мотивации и стимулировало развитие циифровой грамотности у всех участников эксперимента.

Ключевые слова: универсальные компетенции; эмоциональный интеллект; навыки самоконтроля; циирровая грамотность; циифровые инструменты.

\section{Постановка проблемы}

В настоящее время ориентиром в сфере образования является создание условий для внедрения к 2024 г. современной и безопасной цифровой образовательной среды, обеспечивающей формирование ценности к саморазвитию и самообразованию у обучающихся образовательных организаций всех видов и уровней путем обновления информационно-коммуникационной инфраструктуры [1, с. 97].

В проекте «Современная цифровая образовательная среда в Российской Федерации» (2016-2021) ${ }^{1}$ была определена цель - создание условий для системного повышения качества и расширения возможностей непрерывного образования для всех категорий граждан. Ее возможно достичь благодаря становлению российского цифрового образовательного пространства и повышению количества учеников образовательных учреждений, освоивших онлайн-курсы (до 11 миллиона человек к концу 2025 г.).

Термин «цифровая грамотность» в мировом сообществе впервые появился на рубеже 1980-1990-х гг. Первое официальное упоминание данного понятия связывают с именем П. Гилстера и его книгой «Цифровая грамотность», где дается следующее определение понятию «цифровая грамотность» - «умение понимать и использовать информацию, предоставленную во множестве разнообразных

\footnotetext{
${ }^{1}$ Паспорт приоритетного проекта «Современная цифровая образовательная среда в Российской Федерации» утвержден президиумом Совета при Президенте Российской Федерации по стратегическому развитию и приоритетным проектам (протокол от 25
}

(C) 2011-2022 Science for Education Today форматов и широкого круга источников с помощью компьютеров» [цит. по: 2]. Постепенно данный термин стал использоваться в работах и других зарубежных авторов, таких как M. Alcock, M. L. Fisher, S. Hargadon, H. H. Jacobs, B. Sheskey, S. R. Tolisano [3], J. P. Davies, J. Ohler [4], T. Druckrey². Одновременно с такими понятиями, как «интернет-грамотность», «интернет-культура», появляется термин «электронная культура» (e-culture) или «цифровая культура». Так, М. Akçayır, H. Dündar, G. Akçayır исследуют особенности формирования и развития эпохи «цифровых технологий» [5].

В отечественных исследованиях понятие «цифровая грамотность» появилось относительно недавно и не получило единого определения. Наиболее теоретически обоснованным является исследование А. В. Шарикова [6], в котором он выделяет четыре подхода в изучении проблемы цифровой грамотности отечественными авторами, условно подразделяя их на инфокоммуникационно-технологический, психолого-педагогический, медийно-информационный и индустриальный подходы. Содержание цифровой грамотности Н. Д. Берман [7] видит трехчастной: цифровые компетенции, цифровое потребление и цифровая безопасность.

В современных исследованиях все чаще рассматриваются вопросы влияния цифровых

октября 2016. № 9). URL: http://static.government.ru/media/files/8SiLmMBgjAN89vZbUUtmuF51ZYfTvOAG.pdf

${ }^{2}$ Druckrey T. Electronic culture: technology and visual representation. - New York: Aperture, 1996. 
инструментов на рост депрессивных состояний [8-12], изменение структуры мозга [1315], на изменение поведения человека [16-18].

Одновременно исследуются проблемы устойчивости личности к социокультурным угрозам в условиях цифровой трансформации общества [19-25].

В настоящем исследовании будем понимать под цифровой грамотностью участников образовательного процесса способность личности использовать возможности цифровых инструментов с учетом информационной безопасности для самообразования, конструктивного взаимодействия с другими участниками по развитию soft skills.

О проблеме развития soft skills и необходимости их развития говорится в работах О. Абашкиной, Н. В. Жадько, О. Сосницкой, Ю. Портланд, О. Л. Чулановой и др. Исследователи Л. К. Раицкая, Е.В.Тихонова [26] обобщают представления преподавателей и студентов российских университетов о Soft skills в контексте мирового опыта.

O. Абашкина в своей статье «Soft skills: ключ к карьере» ${ }^{3}$ приводит классификацию soft skills по типу деятельности, задается вопросом, что важнее для современного работодателя: «личные качества или диплом». Также в статье автор ссылается на исследование Института Макса Планка (Мюнхен, Германия), в котором перечисляются наиболее значимые гибкие навыки для современного общества (личностная динамика, область межличностных отношений, стремление к успеху, выносливость). Другими словами, под soft skills

\footnotetext{
3 Абашкина O. Soft skills: ключ к карьере. URL: http://www.pro-personal.ru/article/7811-soft-skillsklyuch-k-karere

${ }^{4}$ Там же.

5 Жадько Н. В., Чуркина М. А. Обучение hard skills и soft skills - в чем разница? URL: http://hr-portal.ru/article/obuchenie-hardskills-i-soft-skills-v-chyom-raznic
}

(C) 2011-2022 Science for Education Today
О. Абашкина рассматривает личностные качества, которые являются определяющими для профессионала. Именно благодаря им он достигнет успеха ${ }^{4}$.

Н. В. Жадько и М. А. Чуркина дают обоснование soft skills под углом межличностных отношений, которые складываются в профессиональной сфере, представляют корпоративный интерес, предполагают постановку задач и их решение в профессиональной области ${ }^{5}$.

У О. Сосницкой представлено иное понимание soft skills. Под этим понятием автор подразумевает общечеловеческие качества и навыки, к которым можно отнести, по ее мнению, «коммуникативные и управленческие таланты». Интересное наблюдение приводит O. Сосницкая в своей статье «Soft skills: „мягкие навыки“ твердого характера»: «Чем выше должность, тем большую роль играют социальные навыки» ${ }^{6}$.

Ю. Портланд в статье «Что такое soft skills и почему они так важны для карьеры?» ${ }^{7}$ рассуждает о том, что soft skills больше необходимы для тех, кто собирается занять руководящую должность или работать в сфере обслуживания, при этом ссылается она на исследования Гарвардского университета, где указывается, что $85 \%$ успеха зависит от мягких навыков и только $15 \%$ от жестких. K soft skills автор относит, например, гибкость, умение брать ответственность, умение работать в команде и договариваться, умение мотивировать, обучать других, быть генератором идей.

\footnotetext{
${ }^{6}$ Сосницкая O. Soft skills: мягкие навыки твердого характера. URL: https://www.dw.com/ru/soft-skillsмягкие-навыки-твердого-характера/а-4837922

${ }^{7}$ Портланд Ю. Что такое soft skills и почему они так важны для карьеры? URL: http://dnevnykuspeha.com/rabota-ikarera/chto-takoesoft-skills-i-pochemu-oni-tak-vazhnyi-dlya-kareryi.html
} 
О. Л. Чулановой и соавторами «мягкие навыки» определяются как «социально-трудовая характеристика совокупности знаний, умений, навыков и мотивационных характеристик работника в сфере взаимодействия между людьми, умения грамотно управлять своим временем, умения убеждать, ведения переговоров, лидерства, эмоционального интеллекта, обладающих эмерджентностью, необходимых для успешного выполнения работы и соответствующих требованиям должности и стратегическим целям организации, это характеристика потенциального качества, позволяющего описать практически все элементы готовности персонала к эффективному труду в заданной ситуации на рабочем месте в трудовом коллективе» [27-28].

Многие зарубежные авторы уделяют внимание в своих исследованиях понятиям «социальные навыки» [29-31], «компетентность» [32-35], «мягкие навыки» [36-37] и отмечают значимость soft skills и, следовательно, необходимость их развития на современном этапе [38-41].

В течение последнего десятилетия индивидуальные компетенции и мягкие навыки приобрели первостепенное значение среди ученых в различных областях. Тем не менее, по-видимому, отсутствует консенсус относительно значения обоих понятий в той степени, в какой они иногда взаимозаменяемо используются [42]. В исследовании А. F. Henderman, U. Cantner «Soft skills, hard skills, and individual innovativeness» изучалась взаимосвязь между мягкими навыками, жесткими навыками и индивидуальной инновационностью и был сделан

\footnotetext{
${ }^{8}$ Формирование системы гибких навыков soft skils в образовательном процессе. URL: https://urok.1 sept.ru/articles/675727

9 Что такое hard и soft skills. URL: https://enjoyjob.ru/edu/business-edu/chto-takoe-hard-soft-skills/
}

вывод об отсутствии взаимодополняемости (положительного эффекта взаимодействия) между мягкими и жесткими навыками [43].

Интересные данные были получены и проанализированы службой World Economic Forum. В отчете были представлены Топ-10 гибких навыков, которые будут востребованы в ближайшем будущем. Опираясь на эти данные, возможным стало определение ключевых soft skills, которые необходимо развивать в настоящее время. Главной универсальной компетенцией в современном мире было отмечено умение решать сложные задачи. По рейтингу далее упоминалось умение критически мыслить, на третьем месте стояла креативность. Кроме указанных навыков были перечислены умение работать в команде, умение принимать ответственность за решение, умение убеждать, навыки тайм-менеджмента, навыки самомотивации ${ }^{8,9}$.

В соответствии с разработкой проекта универсальных компетентностей и новой грамотности, в модели выделяются следующие универсальные компетентности, которые формируют основные soft skills:

- компетентность мышления включает такие умения, как умение критически мыслить, решать проблемы, исследовать, проектировать на основе анализа и обобщения ${ }^{10}$;

- компетентность взаимодействия с другими - это такие умения, как инициативность, проявляющаяся в настойчивости, умении самостоятельно работать и внимательно слушать других, планировать; способность к

${ }^{10}$ Катаева Л. Н., Терехова Н. Н. Формирование soft skills у обучающихся учреждений дополнительного образования посредством игровой деятельности // Образование и воспитание. - 2020. - № 3 (29). C. 52-54. URL: https://www.elibrary.ru/item.asp?id=42956797 
адаптации; коммуникационные навыки и умение сотрудничать, работать в команде и являться лидером;

- компетентность взаимодействия с собой - это навыки самоорганизации, самоконтроля, умение рационально организовывать и поэтапно выполнять свою учебную деятельность, корректировать свои действия, сознательно применять накопленные знания, компетенции и опыт.

Исследователи W. Scierski, M. Landrat, K. Pikon, M. Bogacka считают, что поведенческие навыки можно разделить на две группы: личные навыки (способность эффективно управлять собой) и навыки межличностного общения (способность, используемая в отношениях с другими людьми) [44].

Цель статьи - выявить уровень развития soft skills у старшеклассников, обосновать реализацию практико-ориентированных процедур в условиях цифровой образовательной среды и осуществить поиск эффективных подходов в реализации современных задач образования в условиях цифровой образовательной среды по развитию soft skills у старшеклассников.

\section{Методология исследования}

Основным методологическим подходом к рассмотрению проблемы soft skills является компетентностный подход (А. М. Аронов, А. В. Баранников, А. Г. Бурмус, И. А. Зимняя, А. В. Хуторской).

Поиск новых современных методов обучения и воспитания позволил применить подходы, связанные с проблемой информатизации образования (Я. А. Ваграменко, А. П. Ершов, И. В. Роберт, С. А. Танганян).

\footnotetext{
${ }^{11}$ Оценка самоконтроля в общении (по Мариону Снайдеру). URL: https://psylist.net/praktikum/00048.htm
}

В качестве испытуемых выступили 400 обучающихся девятых классов школ Кургана и Курганской области.

Цель констатирующего этапа исследования - выявить исходный уровень сформированности soft skills (навыки самоконтроля, эмоциональный интеллект, умение договариваться, работая в команде) и предложить эффективные инструменты по их развитию soft skills.

В процессе анализа психолого-педагогических источников мы пришли к выводу, что необходимо применить методики М. Снайдера $^{11}$ и Томаса-Килманна ${ }^{12}$. Методика М. Снайдера была использована для определения уровня эмоционального интеллекта старшеклассников. Респондентам предъявлялись утверждения, задача старшеклассников была оценить их, отметив, что «верно», что «неверно».

Нами была разработана программа «Психология личностного роста» с использование материалов электронной платформы «Лифт в будущее» и Learnis.ru. Она направлена на организацию практико-ориентированных процедур для реализации их в условиях цифровой среды образовательного учреждения общего образования. В основе содержания - аксиологический и компетентностный подходы. Содержание практико-ориентированных процедур возможно использовать как в формате офлайн, так и онлайн, как очно, так и дистанционно. Использование цифровых инструментов позволило расширить возможности образовательной среды учреждений общего образования и возможности участников образовательного процесса по развитию soft skills. Содержание работы предполагало мо-

\footnotetext{
12 Методика Томаса - Килманна на выявление ведущего поведения в конфликтной ситуации (в адаптации Н. В. Гришиной). URL: https://nekrasovspb.ru/doc/18tomas-kilmen.pdf
} 
дульную структуру, что дало возможность варьировать его в зависимости от условий, средств, потребностей участников. Обучающиеся включались в практико-ориентированные процедуры в рамках двух модулей: «Я открываю себя» и «Я открываю других». В содержание первого модуля было включено изучение индивидуально-типологических черт личности: темперамента, характера, репрезентативных систем. Обучающиеся через минилекции, консультативные беседы, практикумы осваивали навыки тайм-менеджмента, познавали тайну настроения и открывали секреты эмпатии и знакомились co soft skills. В рамках второго модуля девятиклассники развивали умение определять собственный жизненный сценарий и корректировать его, определять типы конфликтных личностей и особенности поведения с ними, преодолевать барьеры общения, выстраивать стратегии конструктивного взаимодействия. Изучение каждого модуля сопровождалось применением образовательных платформ «Лифт в будущее» и Learnis.ru, с помощью которых ученики проходили викторины, веб-квесты, разные курсы, связанные с «прокачкой» собственных soft skills.

\section{Результаты исследования}

\footnotetext{
13 Рылеева А. С. Особенности развития soft skills у начинающего специалиста // Развитие современных инновационных технологий и методик в образовательных учреждениях: сборник научных статей (Курган, 23 апреля 2021 г.). - Курган: Изд-во Курганского государственного университета, 2021. - С. 220-223.

${ }_{14}$ Рылеева А. С. Организация работы по формированию жизненной перспективы с подростками, оказавшимися в нестабильной ситуации // Духовно-нравственные основы ориентации молодежи на военные профессии: X Сазоновские педагогические чтения. Курган, 2018. - C. 36-40. URL: https://www.elibrary.ru/item.asp?id=37039800
}

Основной задачей образования в настоящее время является подготовка личности к процессу значительных изменений, происходящих в современном мире ${ }^{13}$. Современная парадигма образования требует появления нового типа специалиста, обладающего набором профессионально важных качеств, позволяющих ему быть востребованным и конкурентоспособным ${ }^{14}$, способствует формированию профессиональной ориентации подрастающего поколения (на чем акцентируется внимание и в Стратегии развития воспитания в Российской Федерации ${ }^{15}$ ).

Переход к информационному обществу повлек за собой ряд изменений и привел к появлению инициатив для обеспечения экономического роста нашей страны, например появились «Стратегия развития информационного общества в Российской Федерации на 20172030 годы» (Указ Президента РФ от 9 мая 2017 г. № 203) ${ }^{16}$ и программа «Цифровая экономика Российской Федерации» (распоряжение Правительства РФ от 28 июля 2017 г. № $1632-\mathrm{p})^{17}$.

Одной из основных целей в сфере образования была обозначена необходимость формирования универсальных компетентностей

${ }^{15}$ Стратегия развития воспитания в Российской Федерации на период до 2025 года: распоряжение Правительства РФ от 29 мая 2015 г. № 996-р // Российская газета. - 2015. - 8 июня. - URL: https://rg.ru/2015/06/08/vospitanie-dok.html

16 Указ Президента Российской Федерации от 09.05.2017 г. № 203 «О Стратегии развития информационного общества в Российской Федерации на 2017-2030 годы».

URL: http://www.kremlin.ru/acts/bank/41919

17 Программа «Цифровая экономика Российской Федерации» (распоряжение правительства РФ от 28 июля 2017 г. № 1632-p). URL: http://static.government.ru/media/files/9gFM4FHj4PsB 79I5v7yLVuPgu4bvR7M0.pdf 
через развитие soft skills у учащихся ${ }^{18}$. Результаты показывают, что для улучшения качества человеческого капитала и стимулирования экономического роста странам следует уделять больше внимания разработке национальной политики в области образования, направленной на повышение познавательных навыков учащихся.

Концептуальные основы происходящих изменений образования отражены в международном проекте «Ключевые компетентности и новая грамотность». Трансформация предполагает повышение конкурентоспособности российского образования и развитие человеческого капитала. В федеральном проекте «Цифровая образовательная среда (от 07.12.2018 г. № 3) ${ }^{19}$ прописаны необходимые меры по созданию в школах цифровой образовательной среды и обеспечению нужными цифровыми устройствами для организации учебной и внеучебной деятельностью детей, управления жизнью школы.

С помощью проекта предполагается решить задачи, ориентированные на использование новых методов обучения и воспитания, образовательных технологий, закладывающих основы для базовых навыков и умений, повышение мотивации к обучению и вовлеченности в образовательный процесс детей, а также создание современной безопасной цифровой образовательной среды, обеспечивающей высокое качество и доступность образования всех видов и уровней. Выявление будущих потребностей в компетенциях позволяет системе образования адаптировать процесс профессиональной подготовки инновационных кадров и повысить конкурентноспособность образовательных процессов [1].

Согласно результатам, полученным на исходном уровне диагностики по тесту М. Снайдера, из числа опрошенных старшеклассников с низким уровнем контроля было выявлено $50 \%$, со средним уровнем $-37,5 \%$, высокий уровень контроля был определен у $12,5 \%$. Результаты первоначального диагностического исследования представлены на рисунке 1.

\footnotetext{
18 Универсальные компетентности и новая грамотность: чему учить сегодня для успеха завтра. Предварительные выводы международного доклада о тенденциях трансформации школьного образования / И. Д. Фрумин, М. С. Добрякова, К. А. Баранников,
}

И. М. Реморенко. - М.: Изд-во НИУ ВШЭ, 2018. 28 c.

19 Паспорт Федерального проекта «Цифровая образовательная среда». URL: https://edu54.ru/upload/files/2016/03/Федеральный\%20проект\%20Цифр овая\%20образовательная\%20среда.pdf 


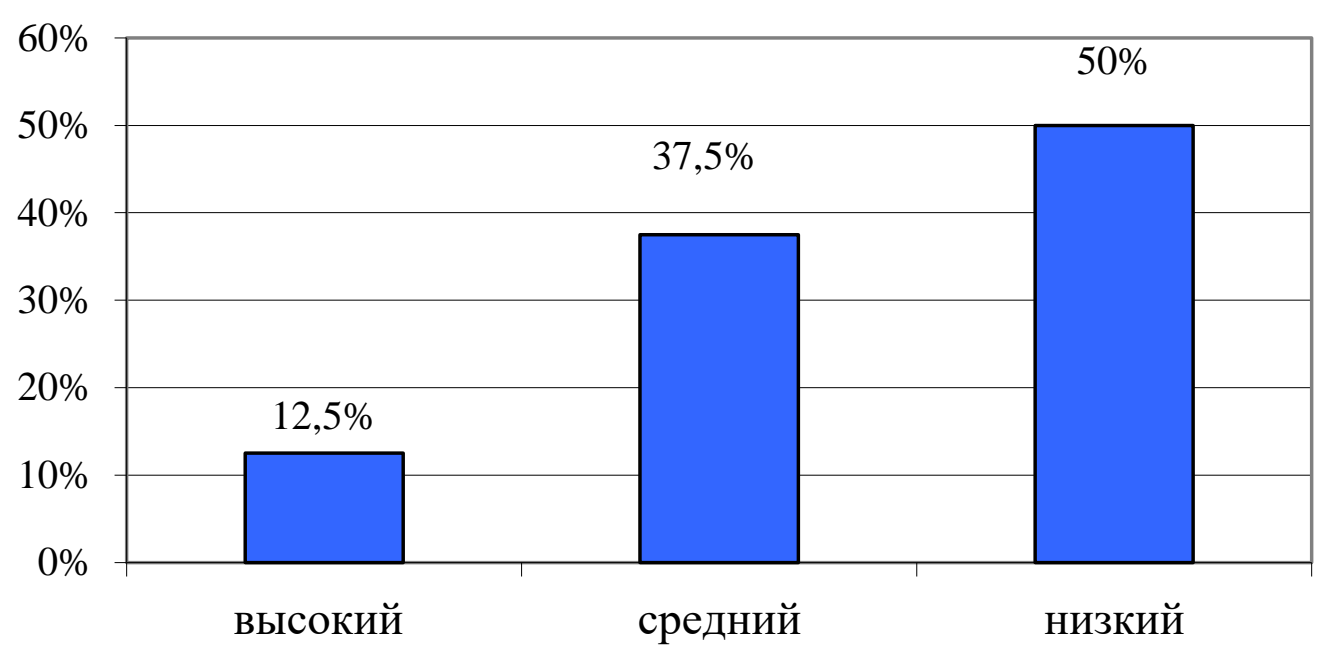

Puc. 1. Результаты проведения первоначальной диагностики по М. Снайдеру

Fig. 1. Results of the initial diagnosis according to M. Snyder

Результаты проведения первоначальной диагностики по М. Снайдеру говорят о необходимости проведения психолого-педагогической деятельности по формированию soft skills у старшеклассников. Это необходимо как для данного возраста детей, так и для их дальнейшей жизни, поступления в вузы и для взаимодействия друг с другом.

Методика Т. Килмана была использована для определения стратегий поведения старшеклассников в конфликте. Респондентам предлагалось из 30 утверждений выбрать варианты ответов, которые наиболее подходят под их стереотипы поведения. Для анализа результатов необходимо было воспользоваться таблицей с описанием пяти типов поведения личности в ситуации конфликта: конфронтация, сотрудничество, компромисс, уклонение и приспособление. Доминирующий тип поведения личности в конфликтных ситуациях определялся по тому, в каком столбике ученик получил наибольшее количество баллов.
По результатам, полученным в ходе опроса, можно отметить, что только 7,5 \% респондентов выбрали тип взаимодействия с другими - «сотрудничество», у $15 \%$ - «приспособление» и «компромисс», 35 \% выбрали «уклонение», «конфронтация» - у 27,5 \% (см. рис. 2). Наблюдается преобладание «конфронтации» и «уклонения», т. е. старшеклассники предпочитают осуществление собственных интересов, нежели одноклассников, и в то же время школьники не готовы уступать ни в чем своими одноклассникам. Средние показатели были по «приспособлению» и «компромиссу», следовательно, необходима групповая работа, которая будет способствовать формированию и развитию умения вести беседы, навыка ориентированности на других, а также и последующего управления людьми.

Таким образом, по результатам первоначального исследования можно сделать вывод, что учащиеся не стремятся предпринимать больше совместных действий, а также удовлетворять интересы одноклассников. 
Science for Education Today

2022. ToM 12. № 1

http://sciforedu.ru

ISSN 2658-6762

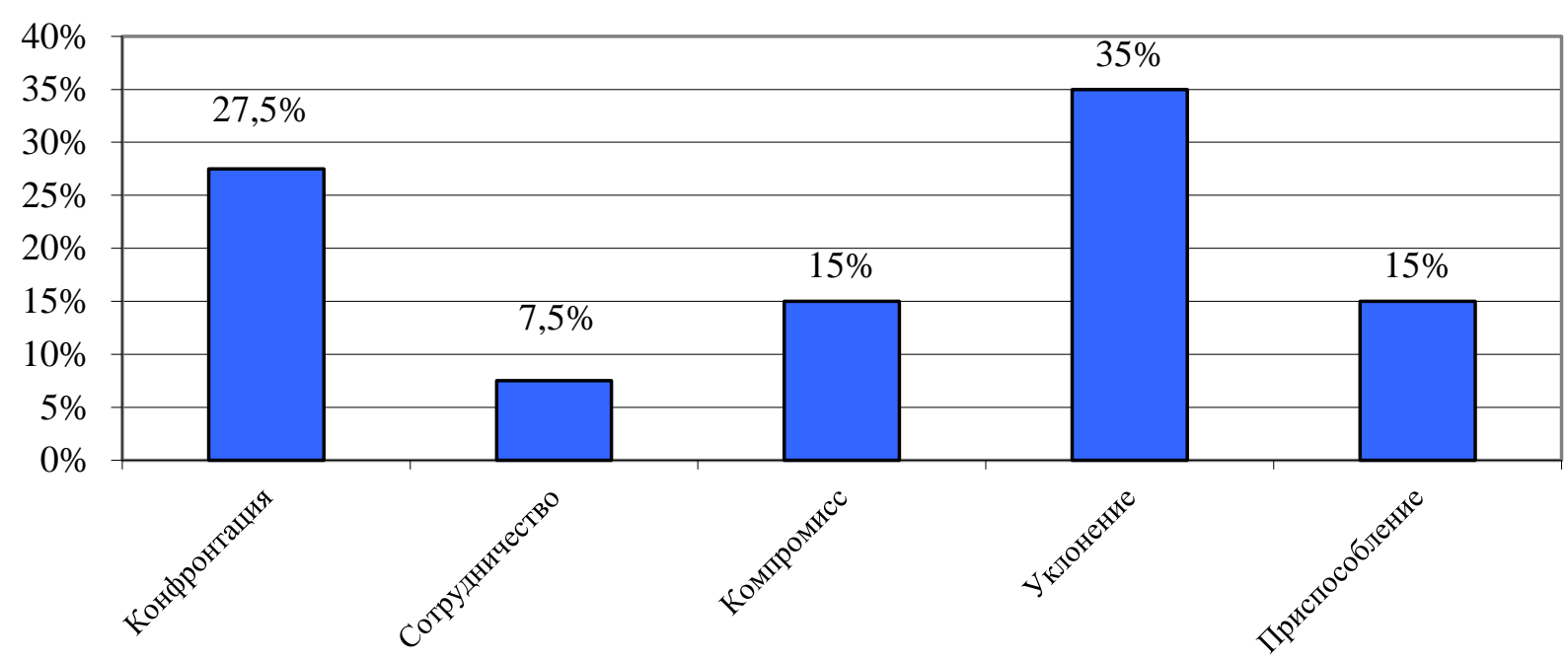

Puc. 2. Особенности выборов старшеклассниками стереотипов поведения в конфликте по методике Т. Килманна

Fig. 2. Features of high school students' choice of stereotypes of behavior

in conflict according to T. Kilmann's method

По результатам повторно проведенной диагностики по методике М. Снайдера нами был выявлен более высокий уровень контроля обучающихся девятых классов при общении друг с другом. Например, из числа респондентов-старшеклассников с низким уровнем контроля осталось только $10 \%$, со средним уровнем было выявлено 52,5 \%, с высоким уровнем контроля было выявлено - 37,5 \% (см. рис. 3 ).

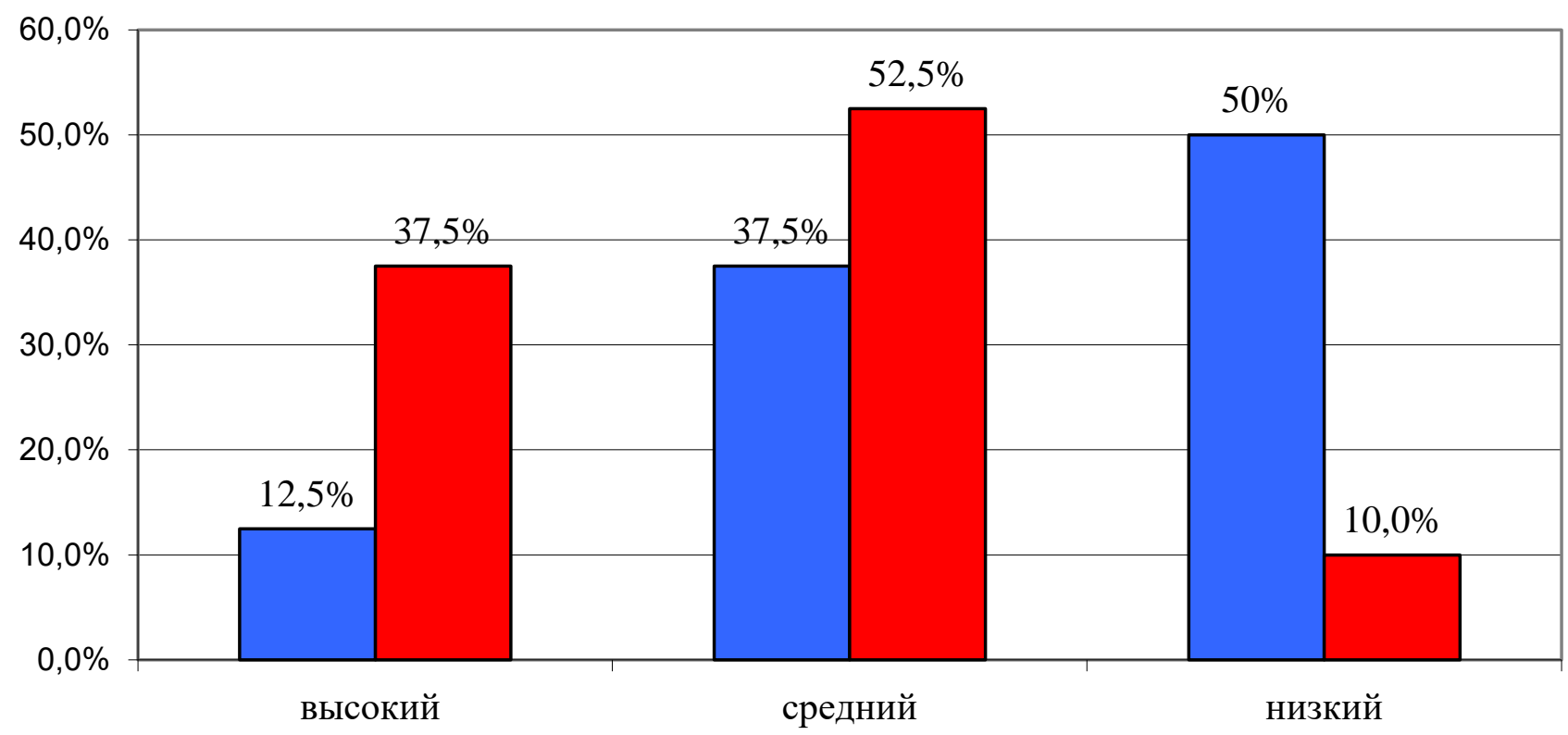

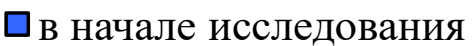
в конце исследования 
Puc. 3. Повторные результаты проведения диагностики по М. Снайдеру Fig. 3. Repeated results of M. Snyder diagnostics

После проведения психолого-педагогической работы со старшеклассниками по формированию soft skills среди испытуемых стало на много меньше учеников, испытывающих эмоциональную неприязнь друг к другу, учащиеся стали эффективнее взаимодействовать друг с другом, чаще общаться как в школе, так и за ее пределами. Изначально старшеклассники были не очень доброжелательными по отношению друг к другу, но после работы по формированию soft skills ситуация изменилась.

По результату проведенной методики мы видим, что изначально старшеклассники преимущественно были со средним и низким уровнем контроля, а по итогам повторно проведенной методики все показатели изменились в лучшую сторону.

По окончанию проведенного исследования дети объединились, сплотились, стали дружнее, внимательнее друг к другу, произошла адаптация в коллективе. Дети, у которых были трудности, наблюдалась эмоциональная неприязнь, стали проще и легче взаимодействовать, общаться, появилась доброжелательность в отношениях друг к другу. По результату, полученному повторно, мы видим, что преобладают старшеклассники с высоким и средним уровнями контроля. Значит, проведенная работа и психолого-педагогическая деятельность по формированию soft skills у старшеклассников способствовала повышению уровня эмоционального интеллекта у обучающихся девятых классов.
Результаты исходной диагностики по М. Снайдеру демонстрируют продуктивность проведения психолого-педагогической деятельности по формированию soft skills у старшеклассников, так как результаты стали выше, а дети дружнее.

По результатам, полученным в ходе повторного исследования по методике Т. Килманна, нами замечено, что у респондентов показатель «сотрудничество» был определен только у 7,5 \%, а при повторном исследовании - уже у $20 \%$, «приспособление» первоначально было выявлено у 15 \%, а при повторном исследовании - у 25 \%, показатель «компромисс» первоначально был выявлен у $15 \%$, при повторно проведенной методике - у $22,5 \%$, показатель «уклонение» первоначально был выявлен у $35 \%$, а при повторном исследовании - 17,5 \%, и «конфронтация» первоначально была выявлена у 27,5 \%, по завершению исследования показатель опустился до $15 \%$ (см. рис. 4).

Мы видим, что первоначально было преобладание «конфронтации» и «уклонения», т. е. старшеклассники предпочитали собственные интересы и не были готовы уступать ни в чем своими одноклассникам. Средние показатели были по «приспособлению» и «компромиссу». Старшеклассники не стремились предпринимать никаких совместных действий, а также помогать и учитывать интересы одноклассников. 
Science for Education Today

2022. ToM 12. № 1

http://sciforedu.ru

ISSN 2658-6762
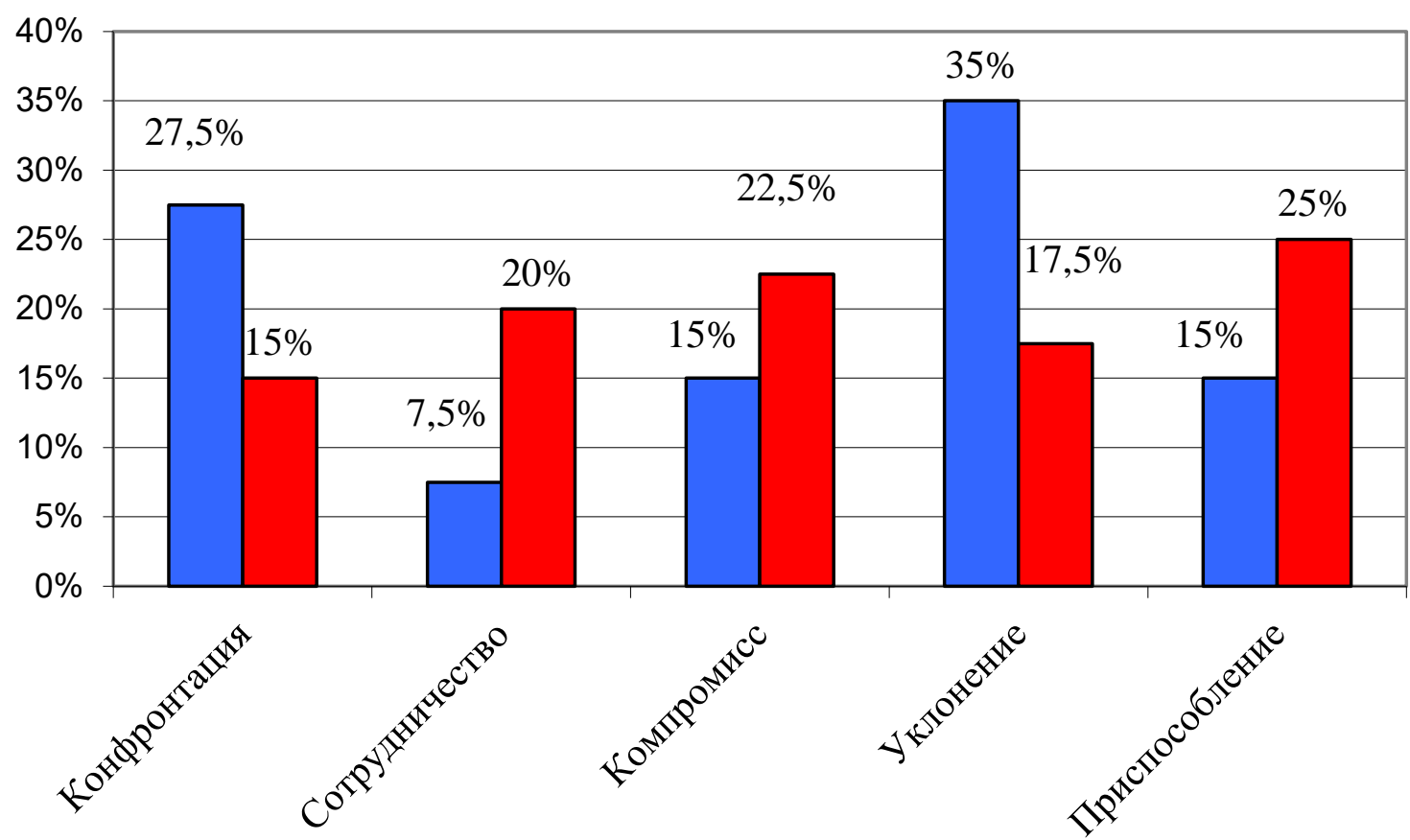

$\square$ в начале

$\square$ в конце

Puc. 4. Результаты повторного диагностического исследования по выявлению типа поведения старшеклассников в конфликтной ситуации Т. Килманна

Fig. 4. The results of a repeated diagnostic study to identify the type of behavior of high school students in a conflict situation by T. Kilmann

Полученные данные в начале и в конце исследования показали, что у старшеклассников повысились показатели по таким типам поведения в конфликтной ситуации, как «сотрудничество», «компромисс», «приспособление», т. е. девятиклассники пытаются выполнить как можно больше вместе, а также им стали близки интересы одноклассников, и они начали проявлять к ним интерес и пытаться помочь решить их проблемы.

Интересно, что в классах показатели по таким параметрам, как «конфронтация» и «избегание» стали значительно ниже. Старшеклассники перестали предпочитать осуществление личных интересов, нежели интересов одноклассников. Выбор таких стилей поведения в конфликте, как «конфронтация», «избегание», снизились. Так, реализуемая нами про- грамма способствовала формированию и развитию умения вести переговоры, навыка ориентированности на людей и управления своими эмоциями.

По завершению проведения диагностики у большинства старшеклассников появились умение активно проявлять себя и уже беспрепятственно и эмоционально взаимодействовать друг с другом. Конечно же, остались ещё и замкнутые учащиеся, которые не научились проявлять инициативу, высказывать свое личное мнение, но несмотря на это они все же перестали бояться и во время опроса уже могли высказать свое мнение и знали, что они найдут поддержку среди одноклассников. Ну и, конечно, появилось много школьников, которые стали активнее, научились брать ответственность за других и за себя, некоторые стали 
проявлять себя как лидеры, и все это способствовало развитию такого умения, как координировать других. Старшеклассники научились выполнять работу при условии, что взаимодействовали не совместно, у них сформировался навык управления людьми, они научились общаться, помогать друг другу и быть увереннее.

Совместная работа также оказала содействие в умении коллектива одноклассников сотрудничать в классах, были установлены дружеские контакты, дети ближе познакомились друг с другом. И все это показало положительную позитивную динамику. В процессе взаимоотношений учащиеся не просто научились общаться друг с другом, но это помогло им добиваться положительных результатов. Они научились выступать, дискутировать, формулировать именно свои выводы и доказывать свою точку зрения, и это все поспособствовало формированию большого дружного коллектива.

Среди испытуемых были выявлены старшеклассники с разными уровнями контроля, в основном со средним и высоким, а также наблюдалась положительная динамика в развитии уровня эмоционального интеллекта у обучающихся в той и другой группе.

\section{Обсуждение, заключение}

На современном этапе содержание работы по подготовке успешной личности необходимо ориентировать на развитие таких личностных качеств, как эмоциональный интеллект, умение ладить с людьми в ситуации конфликта, навыки конструктивного взаимодействия и умение использовать цифровые инструменты.
Анализ и интерпретация результатов исследовательской работы показали эффективность использования содержания психологопедагогической работы по развитию soft skills у обучающихся девятого класса, включающей инвариантный компонент (представление об индивидуально-типологических качествах личности, готовность к личностному самоопределению, способность к саморазвитию, развитие навыков самоконтроля и эмпатии) и вариативный (индивидуальная образовательная траектория).

Использование дифференцированного подхода по развитию soft skills у обучающихся девятого класса помогло преодолеть инвариантные (низкий уровень рефлексии, низкая мобильность) и вариативные трудности, связанные с индивидуально-типологическими особенностями личности, что позволило осуществлять адресную помощь.

Практико-ориентированные процедуры для развития soft skills были разработаны с учетом внедрения дистанционного обучения с применением цифровых инструментов (образовательных платформ «Лифт в будущее» и Learnis.ru), что позволило получить высокие результаты по показателям эмоционального интеллекта и умения сотрудничать.

Практико-ориентированные процедуры развития soft skills предполагают использование возможностей цифровых инструментов с учетом информационной безопасности для самообразования, конструктивного взаимодействия с другими участниками.

\section{СПИСОК ЛИТЕРАТУРЫ}

1 Рылеева А. С., Стефаник Ю. В. Модель формирования цифровой компетентности педагогов образовательной организации // Мир науки, культуры, образования. - 2021. - № 2. - Р. 97- 
99. DOI: https://doi.org/10.24412/1991-5497-2021-287-97-99 URL: https://www.elibrary.ru/item.asp?id=45677559

2 Соболева Ж. С. Теоретические предпосылки формирования понятий «цифровая грамотность» и «цифровая компетенция» // Актуальные проблемы филологии и методики преподавания иностранных языков. - 2019. - № 13. - C. 110-114. URL: https://www.elibrary.ru/item.asp?id=40629885

3 Alcock M., Fisher M. L., Hargadon S., Jacobs H. H., Sheskey B., Tolisano S. R. Mastering digital literacy. - Bloomington, IN: Solution Tree Press, 2014. ISBN: 978-1936764549

4 Davies J. P., Ohler J. DOA: education in the electronic culture. - Lanham, Md.: Scarecrow Press, 2003. ISBN 9780810846944

5 Akçayır M., Dündar H., Akçayır G. What makes you a digital native? Is it enough to be born after 1980? // Computers in Human Behavior. - 2016. - Vol. 60. - P. 435-440. DOI: https://doi.org/10.1016/j.chb.2016.02.089

6 Шариков А. В. Концепции цифровой грамотности: российский опыт // Коммуникации. Медиа. Дизайн. - 2018. - T. 3, № 3. - C. 96-112. URL: https://www.elibrary.ru/item.asp?id=47491089

7 Бердман Н. Д. К вопросу формирования информационной грамотности студентов // Современные проблемы науки и образования. - 2020. - № 4. - C. 3. DOI: https://doi.org/10.17513/spno.29923 URL: https://www.elibrary.ru/item.asp?id=43925018

8 Donati M. A., Sottili E., Morsanyi K., Primi C. Time perspectives and gambling in adolescent boys: Differential effects of present-and future-orientation // Journal of gambling studies. - 2019. Vol. 35 (1). - P. 107-124. DOI: https://doi.org/10.1007/s10899-018-9780-0

9 Alonso-Stuyck P., Zacarés J. J., Ferreres A. Emotional separation, autonomy in decision-making, and psychosocial adjustment in adolescence: A proposed typology // Journal of Child and Family Studies. - 2018. - Vol. 27 (5). - P. 1373-1383. DOI: https://doi.org/10.1007/s10826-017-0980-5

10 Andre L., van Vianen A. E. M., Peetsma T. T. D., Oort F. J. Motivational power of future time perspective: Meta-analyses in education, work, and health // PLoS ONE. - 2018. - Vol. 13 (1). P. e0190492. DOI: https://doi.org/10.1371/journal.pone.0190492

11 Barr N., Pennycook G., Stolz J. A., Fugelsang J. A. The brain in your pocket: evidence that smartphones are used to supplant thinking // Computers in Human Behavior. - 2015. - Vol. 48. P. 473-480. DOI: https://doi.org/10.1016/j.chb.2015.02.029

12 Twenge J. M., Joiner T. E., Martin G., Rogers M. L. Digital media may explain a substantial portion of the rise in depressive symptoms among adolescent girls: response to Daly // Clinical Psychological Science. - 2018. - Vol. 6. - P. 296-297. DOI: https://doi.org/10.1177/2167702618759321

13 Barak M. Are digital natives open to change? Examining flexible thinking and resistance to change // Computers and Education. - 2018. - Vol. 121. - P. 115-123. DOI: https://doi.org/10.1016/j.compedu.2018.01.016

14 O'Connor D. B., Thayer J. F., Vedhara K. M. Stress and health: A review of psychobiological processes // Annual Review of Psychology. - 2021. - Vol. 72 (1). - P. 663-688. DOI: https://doi.org/10.1146/annurev-psych-062520-122331

15 Weber B., Fischer T., Riedl R. Brain and autonomic nervous system activity measurement in software engineering: A systematic literature review // The Journal of Systems and Software. - 2021. Vol. 178. - P. 110946. DOI: https://doi.org/10.1016/j.jss.2021.110946

16 Boddy J., Dominelli L. Social Media and Social Work: The Challenges of a New Ethical Space // Australian Social Work. - 2017. - Vol. 70 (2). $\quad$ - P. 172-184. DOI: https://doi.org/10.1080/0312407X.2016.1224907 
17 Нархов Д. Ю., Нархова Е. Н., Шкурин Д. В. Динамика образовательной активности студенчества под воздействием цифровизации // Образование и наука. - 2021. - № 8. - С. 147-188. DOI: https://doi.org/10.17853/1994-5639-2021-8-147-188 URL: https://elibrary.ru/item.asp?id=46667599

18 Rawat K. S., Sood S. K. Knowledge mapping of computer applications in education using CiteSpace // Computer Applications in Engineering Education, 2021. - Vol. 29 (5). - pp. 13241339. DOI: https://doi.org/10.1002/cae.2238837

19 Takeuchi H., Taki Y., Asano K., Sassa Y., Yokota S., Kotozaki Y., Nouchi R. Kawashima R. Impact of frequency of internet use on development of brain structures and verbal intelligence: longitudinal analyses // Human Brain Mapping. - 2018. - Vol. 39 (11). - P. 4471-4479. DOI: https://doi.org/10.1002/hbm.24286

20 Кисляков П. А., Меерсон А. Л. С., Шмелева Е. А., Александрович М.О. Устойчивость личности к социокультурным угрозам в условиях цифровой трансформации общества // Тhe Образование и наука. - 2021 . - № 9. - C. 142-168. DOI: https://doi.org/10.17853/1994-5639-2021 9-142-168 URL: https://elibrary.ru/item.asp?id=47161951

21 Englund C., Olofsson A. D., Price L. Teaching with technology in higher education: Understanding conceptual change and development in practice // Higher Education Research and Development. 2017. - Vol. 36 (1). - P. 73-87. DOI: https://doi.org/10.1080/07294360.2016.1171300

22 Kurmanov N., Tolysbayev B., Amirova G., Satkanova R., Shamuratova N. Foresight of the innovation manager competencies // Polish Journal of Management Studies. - 2021. - Vol. 23 (2). P. 267-287. DOI: https://doi.org/10.17512/pjms.2021.23.2.16

23 Viner R. M., Russell S. J., Croker H., Packer J., Ward J., Stansfield C., Mytton O., Bonell C., Booy R. School closure and management practices during coronavirus outbreaks including COVID-19: A rapid systematic review // The Lancet. Child \& Adolescent Health. - 2020. Vol. 4 (5). - P. 397-404. DOI: https://doi.org/10.1016/S2352-4642(20)30095-X

24 Leahy S. M., Holland C., Ward F. The digital frontier: Envisioning future technologies impact on the classroom // Futures. - 2019. -Vol. 113. - P. 102422. DOI: https://doi.org/10.1016/j.futures.2019.04.009

25 Luo H., Li G., Feng Q., Yang Y., Zuo M. Virtual reality in K-12 and higher education: A systematic review of the literature from 2000 to 2019 // Journal of Computer Assisted Learning. - 2021. Vol. 37 (3). - P. 887-901. DOI: https://doi.org/10.1111/jcal.12538

26 Раицкая Л. К., Тихонова Е. В. Soft skills в представлении преподавателей и студентов российских университетов в контексте мирового опыта // Вестник РУДН. Серия «Психология и педагогика». - 2018. - Т. 15, № 3. - С. 350-363. DOI: https://doi.org/10.22363/2313-1683-201815-3-350-363 URL: https://www.elibrary.ru/item.asp?id=35721716

27 Ивонина А. И., Чуланова О. Л., Давлетшина Ю. М. Современные направления теоретических и методических разработок в области управления: роль soft-skills и hard skills в профессиональном и карьерном развитии сотрудников // Интернет-журнал «Науковедение». 2017. - T. 9, № 1. - C. 90. URL: https://www.elibrary.ru/item.asp?id=29105150

28 Чуланова О. Л., Ивонина А. И. Формирование soft-skills (мягких компетенций): подходы к интеграции российского и зарубежного опыта, классификация, операционализация // Управление персоналом и интеллектуальными ресурсами в России. - 2017. - № 1 (28). - С. 53-58. DOI: https://doi.org/10.12737/24692 URL: https://www.elibrary.ru/item.asp?id=28801167

29 Ackerman P. L. Individual differences in skill learning: An integration of psychometric and information processing perspectives // Psychological Bulletin. - 1987. - Vol. 102 (1). - P. 3-27. DOI: http://dx.doi.org/10.1037/0033-2909.102.1.3 
30 Canning R. Education: Skills Training // International Encyclopedia of the Social and Behavioral Sciences (Second Edition). Elsevier. - 2015. - P. 215-217. DOI: http://dx.doi.org/10.1016/B9780-08-097086-8.92054-3

31 Tastan H., Erdogan S. Cognitive skills and economic performance evidence from the recent international student assessment tests // Eurasian Economic Review. - 2018. - Vol. 8. - P. 417-449. DOI: https://doi.org/10.1007/s40822-018-0099-z

32 Anton-Sancho A., Vergara D., Fernandez-Arias P. Self-Assessment of Soft Skills of University Teachers from Countries with a Low Level of Digital Competence // Electronics. - 2021. Vol. 10 (20). - P. 2532. DOI: https://doi.org/10.3390/electronics10202532

33 Chen W., Zhu W., Mason S., Hammond-Bennett A., Colombo-Dougovito A. Effectiveness of quality physical education in improving students' manipulative skill competency // Journal of Sport and Health Science. - 2016. - Vol. 5 (2). - P. 231-238. DOI: https://doi.org/10.1016/j.jshs.2015.04.005

34 Weis S., Conzelmann K. Social Intelligence and Competencies // International Encyclopedia of the Social and Behavioral Sciences (Second Edition). Elsevier, 2015. - P. 371-379. DOI: http://dx.doi.org/10.1016/B978-0-08-097086-8.25094-0

35 Vorwerg C. Communicative Competence: Linguistic Aspects // International Encyclopedia of the Social and Behavioral Sciences (Second Edition). Elsevier, 2015. - P. 294-301. DOI: https://doi.org/10.1016/B978-0-08-097086-8.53042-6

36 Fernandez-Arias P., Anton-Sancho A., Vergara D., Barrientos A. Soft Skills of American University Teachers: Self-Concept // Sustainability. - 2021. - Vol. 13 (22). - P. 12397. DOI: https://doi.org/10.3390/su132212397

37 Marsenaro-Gutierrez O. D., Lopez-Aguado L. A. Henriques K. O Are soft skills conditioned by conflicting factors? // Economic analysis and Policy. - 2021. - Vol. 72. - P. 18-40. DOI: https://doi.org/10.1016/j.eap.2021.07.008

38 Brown C. P., Weber N. B. Struggling to Overcome the State's Prescription for Practice: A Study of a Sample of Early Educators' Professional Development and Action Research Projects in a HighStakes Teaching Context // Journal of Teacher Education. - 2016. - Vol. 67 (3). - P. 183-202. DOI: https://doi.org/10.1177/0022487116636452

39 Gonzalez-Lorente C., Martinez-Clares P. Which Factors Influence a University Student's Entry into the Workforce? // Revista Española de Investigaciones Sociológicas. - 2021. - Vol. 176. - P. 5978. DOI: https://doi.org/10.5477/cis/reis.176.59

40 Icenogle G., Steinberg L., Duell N., Chein J., Chang L., Chaudhary N., Di Giunta L., Dodge K. A., Fanti K. A., Lansford J. E., Oburu P., Pastorelli C., Skinner A. T., Sorbring E., Tapanya S., Uribe Tirado L. M., Alampay L. P., Al-Hassan S. M., Takash H. M. S., Bacchini D. Adolescents' cognitive capacity reaches adult levels prior to their psychosocial maturity: Evidence for a "maturity gap" in a multinational, cross-sectional sample // Law and Human Behavior. - 2019. Vol. 43 (1). - P. 69-85. DOI: https://doi.org/10.1037/lhb0000315

41 Lopez-Garcia I. M., Brenes L. S. Educational Innovation for the Preparation of Social Workers in a Spanish University // Trabajo Social. - 2018. - Vol. 20 (2). - P. 95-116. DOI: https://doi.org/10.15446/ts.v20n2.74307

42 Marin-Zapata S., Roman-Calderon J., Robledo-Ardila C., Jaramillo-Serna M. Soft skills, do we know what we are talking about? // Review of Managerial Science. - 2021. DOI: https://doi.org/10.1007/s11846-021-00474-9

43 Henderman A. F., Cantner U. Soft skills, hard skills, and individual innovativeness // Eurasian Business Review. - 2018. - Vol. 8. - P. 139-169. DOI: https://doi.org/10.1007/s40821-017-0076-6 
44 Scierski W., Landrat M., Pikon K., Bogacka M. Developing behavioral skills within selected laboratory tests // ICERI2019 Proceedings (ICERI 2019, $12^{\text {th }}$ International Conference of Education, Research and Innovation Seville, Spain, 11 ${ }^{\text {th }}-13^{\text {th }}$ November, 2019). - P. 6846-6850. DOI: https://doi.org/10.21125/iceri.2019.1630

Поступила: 30 Ноября 2021 Принята: 10 января 2022 Опубликована: 28 февраля 2022

\section{Заявленный вклад авторов:}

Рылеева Анастасия Сергеевна: сбор материалов и инициация исследования; определение методологии исследования; анализ данных исследования.

Хомутникова Елена Анатольевна: сбор материалов, проведение исследования.

Еманова Светлана Владимировна: сбор материалов; постановка научной проблемы исследования и определение основных направлений ее решения; структурирование и анализ данных, автор-корреспондент и руководитель проекта.

\section{Информация о конфликте интересов:}

Авторы заявляют об отсутствии конфликта интересов.

\section{Информация об авторах}

\section{Рылеева Анастасия Сергеевна}

кандидат педагогических наук, доцент кафедры педагогики и методики обучения гуманитарным дисциплинам ул. Советская, 63, стр.4, 640020, Курган, Россия. ORCID ID: https://orcid.org/0000-0002-4699-5096

E-mail: ras290577@mail.ru

\section{Хомутникова Елена Анатольевна}

кандидат филологических наук, доцент, кафедра педагогики и методики обучения гуманитарным дисциплинам, Курганский государственный университет, ул. Советская, 63, стр.4, 640020, Курган, Россия. ORCID ID: https://orcid.org/0000-0002-7139-3230 E-mail: ea7878@mail.ru

\section{Еманова Светлана Владимировна}

кандидат педагогических наук, доцент, кафедра педагогики и методики обучения гуманитарным дисциплинам Курганский государственный университет, ул. Советская, 63, стр.4, 640020, Курган, Россия. ORCID ID: https://orcid.org/0000-0003-1387-6987

E-mail: sv_eman@mail.ru 


\title{
Developing soft skills in high school students using digital tools
}

\author{
Anastasia S. Ryleeva ${ }^{1}$, Elena A. Khomutnikova ${ }^{1}$, Svetlana V. Emanova $\square^{1}$ \\ ${ }^{1}$ Kurgan State University, Kurgan, Russian Federation
}

\begin{abstract}
Introduction. The article presents an overview of the research on developing soft skills in high school students, research findings on the assessment of universal competencies in high school students and the search for approaches to the development of universal competencies in high school students by means of using digital tools.

The purpose of the study is to evaluate the level of soft skills among high school students and to justify the implementation of practical procedures within the framework of a digital learning environment.

Materials and Methods. In order to assess the level of soft skills (e.g. emotional intelligence and self-monitoring) in Russian ninth graders $(n=400)$ the authors applied the following general research methods: analysis, synthesis, and reviewing research literature. Empirical methods including M.Snyder's Self-monitoring scale and Thomas-Kilmann's inventory were used to reveal the types of behaviors for handling conflicts. The authors developed practical procedures aimed at enhancing selfcontrol, communication and cooperation skills, and emotional intelligence, using Lift to Future and Learnis.ru educational platforms.

The research methodology was based on the competence approach (A. M. Aronov, A. V. Barannikov, A. G. Burmus, I. A. Zimnaya, A. V. Khutorskoy) and modern approaches related to the problem of digitalization of education (Ya. A. Vahramenko, A. P. Ershov, I. V. Robert, S. A. Tanganyan).

Results. The study revealed the main deficiencies in soft skills among the surveyed $9^{\text {th }}$ graders. The authors identified invariant (lack of self-reflection, lack of motivation for self-development, unwillingness to change) and variable difficulties that impede the development of soft skills in ninth graders and are associated with individual personality traits: lack of self-confidence, excessive ambitions and desires, emotional immaturity, and increased fatigue.

The study revealed a low level of emotional intelligence in $50 \%$ of the respondents and a low level of cooperation skills in $75 \%$ of the respondents. The authors presented a range of practical procedures based on using digital tools, which contributed to the development of soft skills indicators
\end{abstract}

\section{For citation}

Ryleeva A. S., Khomutnikova E. A., Emanova S. V. Developing soft skills in high school students using digital tools. Science for Education Today, 2022, vol. 12 (1), pp.77-98. DOI: http://dx.doi.org/10.15293/2658-6762.2201.04

曰Corresponding Author: Svetlana V.Emanova,sv_eman@mail.ru

(C) Anastasia S. Ryleeva, Elena A. Khomutnikova, Svetlana V. Emanova, 2022 


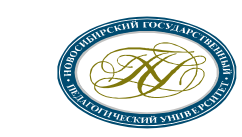

Science for Education Today

2022, vol. 12, issue 1 http://en.sciforedu.ru/

ISSN 2658-6762

in high school students. The study suggests that measures aimed at enhancing soft skills should include both group and individual activities and take into account invariant and variable negative factors. The authors enrich the term 'digital literacy' with new content.

Conclusions. Finally, the authors emphasize that digital tools contributed to maintaining motivation and increasing digital literacy in all the participants of the experiment.

\section{Keywords}

Soft skills; Universal competencies; Emotional intelligence; Self-monitoring skills; Digital literacy; Digital tools.

\section{REFERENCES}

1 Ryleeva A. S., Stefanik J. V. The model of formation of digital competence of teachers of the educational organization. The World of Science, Culture, Education, 2021, no. 2, pp. 97-99. (In Russian) DOI: https://doi.org/10.24412/1991-5497-2021-287-97-99 URL: https://www.elibrary.ru/item.asp?id=45677559

2 Soboleva $\mathrm{Zh}$. S. Theoretical prerequisites for the formation of the concepts of "digital literacy" and "digital competence". Actual Problems of Philology and Methods of Teaching Foreign Languages, 2019, no. 13, pp. 110-114. (In Russian) URL: https://www.elibrary.ru/item.asp?id=40629885

3 Alcock M., Fisher M. L., Hargadon S., Jacobs H. H., Sheskey B., Tolisano S. R. Mastering Digital Literacy. Bloomington, IN: Solution Tree Press, 2014. ISBN: 978-1936764549

4 Davies J. P., Ohler J. DOA: Education in the Electronic Culture. Lanham, Md.: Scarecrow Press, 2003. ISBN 9780810846944

5 Akçayır M., Dündar H., Akçayır G. What makes you a digital native? Is it enough to be born after 1980? Computers in Human Behavior, 2016, vol. 60, pp. 435-440. DOI: https://doi.org/10.1016/j.chb.2016.02.089

6 Sharikov A. V. Digital literacy concepts: Russian experience. Communications. Media. Design, 2018, vol. 3 (3), pp. 96-112. (In Russian) URL: https://www.elibrary.ru/item.asp?id=47491089

7 Berman N. D. To the question of forming information literacy of students. Modern Problems of Science and Education, 2020, no. 4, pp. 3. (In Russian) DOI: https://doi.org/10.17513/spno.29923 URL: https://www.elibrary.ru/item.asp?id=43925018

8 Donati M. A., Sottili E., Morsanyi K., Primi C. Time perspectives and gambling in adolescent boys: Differential effects of present-and future-orientation. Journal of Gambling Studies, 2019, vol. 35 (1), pp. 107-124. DOI: https://doi.org/10.1007/s10899-018-9780-0

9 Alonso-Stuyck P., Zacarés J. J., Ferreres A. Emotional separation, autonomy in decision-making, and psychosocial adjustment in adolescence: A proposed typology. Journal of Child and Family Studies, 2018. vol. 27 (5), pp. 1373-1383. DOI: https://doi.org/10.1007/s10826-017-0980-5

10 Andre L., van Vianen A. E. M., Peetsma T. T. D., Oort F. J. Motivational power of future time perspective: Meta-analyses in education, work, and health. PLOS ONE, 2018, vol. 13 (1), pp. e0190492. DOI: https://doi.org/10.1371/journal.pone.0190492

11 Barr N., Pennycook G., Stolz J. A., Fugelsang J. A. The brain in your pocket: Evidence that smartphones are used to supplant thinking. Computers in Human Behavior, 2015, vol. 48, pp. 473 480. DOI: https://doi.org/10.1016/j.chb.2015.02.029

12 Twenge J. M., Joiner T. E., Martin G., Rogers M. L. Digital media may explain a substantial portion of the rise in depressive symptoms among adolescent girls: Response to Daly. Clinical Psychological Science, 2018, vol. 6, pp. 296-297. DOI: https://doi.org/10.1177/2167702618759321 


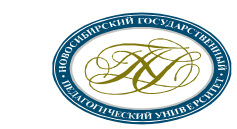

Science for Education Today

2022, vol. 12, issue 1 http://en.sciforedu.ru/

ISSN 2658-6762

13 Barak M. Are digital natives open to change? Examining flexible thinking and resistance to change. Computers and Education, 2018, vol. 121, pp. 115-123. DOI: https://doi.org/10.1016/j.compedu.2018.01.016

14 O'Connor D. B., Thayer J. F., Vedhara K. M. Stress and health: A review of psychobiological processes. Annual Review of Psychology, 2021, vol. 72 (1), pp. 663-688. DOI: https://doi.org/10.1146/annurev-psych-062520-122331

15 Weber B., Fischer T., Riedl R. Brain and autonomic nervous system activity measurement in software engineering: A systematic literature review. The Journal of Systems and Software, 2021, vol. 178, pp. 110946. DOI: https://doi.org/10.1016/j.jss.2021.110946

16 Boddy J., Dominelli L. Social media and social work: the challenges of a new ethical space. Australian Social Work, 2017, vol. 70 (2), pp. 172-184. DOI: https://doi.org/10.1080/0312407X.2016.1224907

17 Narkhov D. Y., Narkhova E. N., Shkurin D. V. Dynamics of educational activity of students under the influence of digitalisation. The Education and Science Journal, 2021, vol. 23 (8), pp. 147-188. (In Russian) DOI: https://doi.org/10.17853/1994-5639-2021-8-147-188 URL: https://elibrary.ru/item.asp?id=46667599

18 Rawat K. S., Sood S. K. Knowledge mapping of computer applications in education using CiteSpace. Computer Applications in Engineering Education, 2021, vol. 29 (5), pp. 1324-1339. DOI: https://doi.org/10.1002/cae.22388 37

19 Takeuchi H., Taki Y., Asano K., Sassa Y., Yokota S., Kotozaki Y., Nouchi R., Kawashima R. Impact of frequency of internet use on development of brain structures and verbal intelligence: Longitudinal analyses. Human Brain Mapping, 2018, vol. 39 (11), pp. 4471-4479. DOI: https://doi.org/10.1002/hbm.24286

20 Kislyakov P. A., Meyerson I. S., Shmeleva E. A., Aleksandrovich M. O. Personal resilience to socio-cultural threats in the context of digital transformation of society. The Education and Science Journal, 2021, vol. 23 (9), pp. 142-168. (In Russian) DOI: https://doi.org/10.17853/1994-56392021-9-142-168 URL: https://elibrary.ru/item.asp?id=47161951

21 Englund C., Olofsson A. D., Price L. Teaching with technology in higher education: Understanding conceptual change and development in practice. Higher Education Research and Development, 2017, vol. 36 (1), pp. 73-87. DOI: https://doi.org/10.1080/07294360.2016.1171300

22 Kurmanov N., Tolysbayev B., Amirova G., Satkanova R., Shamuratova N. Foresight of the innovation manager competencies. Polish Journal of Management Studies, 2021, vol. 23 (2), pp. 267-287. DOI: https://doi.org/10.17512/pjms.2021.23.2.16

23 Viner R. M., Russell S. J., Croker H., Packer J., Ward J., Stansfield C., Mytton O., Bonell C., Booy R. School closure and management practices during coronavirus outbreaks including COVID-19: A rapid systematic review. The Lancet. Child \& Adolescent Health, 2020, vol. 4 (5), pp. 397-404. DOI: https://doi.org/10.1016/S2352-4642(20)30095-X

24 Leahy S. M., Holland C., Ward F. The digital frontier: Envisioning future technologies impact on the classroom. Futures, 2019, vol. 113, pp. 102422. DOI: https://doi.org/10.1016/j.futures.2019.04.009

25 Luo H., Li G., Feng Q., Yang Y., Zuo M. Virtual reality in K-12 and higher education: A systematic review of the literature from 2000 to 2019. Journal of Computer Assisted Learning, 2021, vol. 37 (3), pp. 887-901. DOI: https://doi.org/10.1111/jcal.12538

26 Raitskaya L. K., Tikhonova E. V. Perceptions of soft skills by Russia's university lecturers and students in the context of the world experience. RUDN Journal. Psychology and Pedagogy, 2018, 


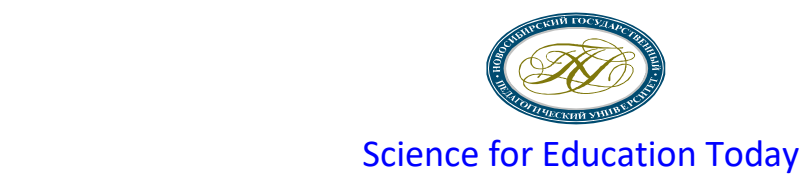

2022, vol. 12, issue 1 http://en.sciforedu.ru/

ISSN 2658-6762

vol. 15 (3), pp. 350-363. (In Russian) DOI: https://doi.org/10.22363/2313-1683-2018-15-3-350363 URL: https://www.elibrary.ru/item.asp?id=35721716

27 Ivonina A. I., Chulanova O. L., Davletshina Yu. M. Modern directions of theoretical and methodological developments in the field of management: The role of soft-skills and hard skills in professional and career development of employees. Naukovedenie, 2017, vol. 9 (1), pp. 90. (In Russian) URL: https://www.elibrary.ru/item.asp?id=29105150

28 Chulanova O. L., Ivonina A. I. Formation of soft skils: Approaches to integrating Russian and foreign experience, classification, operationalization. Personnel and Intellectual Resources Management in Russia, 2017, no. 1, pp. 53-58. (In Russian) DOI: https://doi.org/10.12737/24692 URL: https://www.elibrary.ru/item.asp?id=28801167

29 Ackerman P. L. Individual differences in skill learning: An integration of psychometric and information processing perspectives. Psychological Bulletin, 1987, vol. 102 (1), pp. 3-27. DOI: http://dx.doi.org/10.1037/0033-2909.102.1.3

30 Canning R. Education: Skills training. International Encyclopedia of the Social and Behavioral Sciences (Second Edition). Elsevier, 2015, pp. 215-217. DOI: http://dx.doi.org/10.1016/B978-008-097086-8.92054-3

31 Tastan H., Erdogan S. Cognitive skills and economic performance evidence from the recent international student assessment tests. Eurasian Economic Review, 2018, vol. 8. pp. 417-449. DOI: https://doi.org/10.1007/s40822-018-0099-z

32 Anton-Sancho A., Vergara D., Fernandez-Arias P. Self-Assessment of soft skills of university teachers from countries with a low level of digital competence. Electronics, 2021, vol. 10 (20), pp. 2532. DOI: https://doi.org/10.3390/electronics10202532

33 Chen W., Zhu W., Mason S., Hammond-Bennett A., Colombo-Dougovito A. Effectiveness of quality physical education in improving students' manipulative skill competency. Journal of Sport and Health Science, 2016, vol. 5 (2), pp. 231-238. DOI: https://doi.org/10.1016/j.jshs.2015.04.005

34 Weis S., Conzelmann K. Social intelligence and competencies. International Encyclopedia of the Social and Behavioral Sciences (Second Edition). Elsevier, 2015, pp. 371-379. DOI: http://dx.doi.org/10.1016/B978-0-08-097086-8.25094-0

35 Vorwerg C. Communicative competence: Linguistic aspects. International Encyclopedia of the Social and Behavioral Sciences (Second Edition). Elsevier, 2015. pp. 294-301. DOI: https://doi.org/10.1016/B978-0-08-097086-8.53042-6

36 Fernandez-Arias P., Anton-Sancho A., Vergara D., Barrientos A. Soft skills of American university teachers: Self-concept. Sustainability, 2021, vol. 13 (22), pp. 12397. DOI: https://doi.org/10.3390/su132212397

37 Marsenaro-Gutierrez O. D., Lopez-Aguado L. A. Henriques K. O Are soft skills conditioned by conflicting factors? Economic analysis and Policy, 2021. vol. 72, Pp. 18-40. DOI: https://doi.org/10.1016/j.eap.2021.07.008

38 Brown C. P., Weber N. B. Struggling to overcome the state's prescription for practice: A study of a sample of early educators' professional development and action research projects in a high-stakes teaching context. Journal of Teacher Education, 2016, vol. 67 (3), pp. 183-202. DOI: https://doi.org/10.1177/0022487116636452

39 Gonzalez-Lorente C., Martinez-Clares P. Which factors influence a university student's entry into the workforce? Revista Española de Investigaciones Sociológicas, 2021, vol. 176, pp. 59-78. DOI: https://doi.org/10.5477/cis/reis.176.59

40 Icenogle G., Steinberg L., Duell N., Chein J., Chang L., Chaudhary N., Di Giunta L., Dodge K. A., Fanti K. A., Lansford J. E., Oburu P., Pastorelli C., Skinner A. T., Sorbring E., Tapanya S., 
Uribe Tirado L. M., Alampay L. P., Al-Hassan S. M., Takash H. M. S., Bacchini D. Adolescents' cognitive capacity reaches adult levels prior to their psychosocial maturity: Evidence for a "maturity gap" in a multinational, cross-sectional sample. Law and Human Behavior, 2019, vol. 43 (1), pp. 69-85. DOI: https://doi.org/10.1037/lhb0000315

41 Lopez-Garcia I. M., Brenes L. S. Educational innovation for the preparation of social workers in a Spanish University. Trabajo Social, 2018, vol. 20 (2), pp. 95-116. DOI: https://doi.org/10.15446/ts.v20n2.74307

42 Marin-Zapata S., Roman-Calderon J., Robledo-Ardila C., Jaramillo-Serna M. Soft skills, do we know what we are talking about? Review of Managerial Science, 2021. DOI: https://doi.org/10.1007/s11846-021-00474-9

43 Henderman A. F., Cantner U. Soft skills, hard skills, and individual innovativeness. Eurasian Business Review, 2018, vol. 8, pp.139-169. DOI: https://doi.org/10.1007/s40821-017-0076-6

44 Scierski W., Landrat M., Pikon K., Bogacka M. Developing behavioral skills within selected laboratory tests. ICERI2019 Proceedings (ICERI 2019, $12^{\text {th }}$ International Conference of Education, Research and Innovation Seville, Spain), 2019, pp. 6846-6850. DOI: https://doi.org/10.21125/iceri.2019.1630

Submitted: 30 November 2021 Accepted: 10 January 2022 Published: 28 February 2022

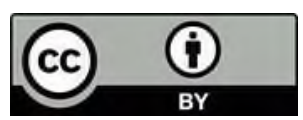

This is an open access article distributed under the Creative Commons Attribution License which permits unrestricted use, distribution, and reproduction in any medium, provided the original work is properly cited. (CC BY 4.0).

\section{The authors' stated contribution:}

Anastasia Sergeevna Ryleeva

Contribution of the co-author: collection of materials and initiation of research; definition of research methodology; analysis of research data of the research.

Elena Anatolyevna Khomutnikova

Contribution of the co-author: collection of materials, preparation of the initial version of the text of the research.

Svetlana Vladimirovna Emanova

Contribution of the co-author: the collection of materials; formulation of a scientific problem research and definition of the main directions of its decision; structuring and analysis of data, corresponding author, project manager.

\section{Information about competitive interests:}

The authors claim that they do not have competitive interests. 


\section{Information about the Authors}

\section{Anastasia Sergeevna Ryleeva}

Candidate of Pedagogical Sciences, Associate Professor,

Department of Pedagogy and Methods of Teaching Humanities,

Kurgan State University,

Sovetskaya str., 63, p. 4, 640020, Kurgan, Russian Federation.

ORCID ID: https://orcid.org/0000-0002-4699-5096

E-mail: ras290577@mail.ru

\section{Elena Anatolyevna Khomutnikova}

Candidate of Philological Sciences, Associate Professor,

Department of Pedagogy and Methods of Teaching Humanities,

Kurgan State University,

Sovetskaya str., 63, p. 4, 640020, Kurgan, Russian Federation.

ORCID ID: https://orcid.org/0000-0002-7139-3230

E-mail: ea7878@mail.ru

\section{Svetlana Vladimirovna Emanova}

Candidate of Pedagogical Sciences, Associate Professor,

Department of Pedagogy and Methods of Teaching Humanities,

Kurgan State University,

Sovetskaya str., 63, p. 4, 640020, Kurgan, Russian Federation.

ORCID ID: https://orcid.org/0000-0003-1387-6987

E-mail: sv_eman@mail.ru (Corresponding Author) 


\section{Региональная модель подготовки педагогических кадров как объект исследования}

Л. Ф. Шаламова ${ }^{1,2}$, Д. М. Марусяк ${ }^{1}$ Т. Н. Владимирова ${ }^{1}$, Н. Ю. Лесконог $\AA^{1}$

${ }^{1}$ Московский педагогический государственный университет, Москва, Россия

${ }^{2}$ Московский авиационный институт (национальный исследовательский университет) (МАИ), Москва, Россия

Проблема и цель. Авторами исследуется проблема повышения качества всех видов образования, прежде всего педагогического. Цель исследования - выявление особенностей современных региональных моделей подготовки педагогических кадров с помощью метода системного моделирования.

Методология. Исследование региональных моделей подготовки педагогических кадров было осуществлено на основе следующих методов: метод фокус-группы; метод экспертного опроса высококвалифичированных спечиалистов и руководителей организаций выстего, среднего профессионального и общего образования и сферы отдыха и оздоровления детей; соичологического опроса. Сравнительный анализ региональных моделей был осуществлен на основе разработанного авторским коллективом паспорта региональной образовательной модели подготовки кадров.

Результаты. В статье представлен обзор современных региональных моделей подготовки педагогических кадров. Сравнительный анализ моделей региональных систем подготовки педагогических кадров выполнен на примере 8 федеральных округов Российской Федерации, выявлены особенности взаимодействия федеральных и региональных участников образовательного прочесса.

Проанализированы и описаны восемь наиболее распространенных моделей подготовки педагогических кадров в региональных системах образования в каждом из федеральных округов, отмечена важность привлечения внимания педагогической общественности к необходимости документировать свой уникальный опыт и представлять его на основе унифичированного паспорта модели, расширять сетевое взаимодействие, привлекая к сотрудничеству как региональных, так и федеральных участников образовательного процесса.

Финансирование проекта: Данная статья подготовлена по заказу Министерства просвещения Российской Федерации в рамках реализации научно-исследовательского проекта «Сравнительный анализ моделей региональных систем подготовки педагогических кадров на примере 8 федеральных округов Российской Федерации и особенности взаимодействия федеральных и региональных участников образовательного процесса» в 2021 году.

Библиографическая ссылка: Шаламова Л. Ф., Марусяк Д. М., Владимирова Т. Н., Лесконог Н. Ю. Региональная модель подготовки педагогических кадров как объект исследования // Science for Education Today. - 2022. - T. 12, № 1. - C. 99-125. DOI: http://dx.doi.org/10.15293/2658-6762.2201.05

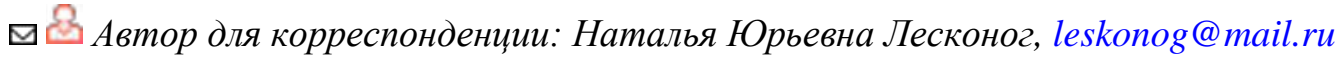

(С Л. Ф. Шаламова, Д. М. Марусяк, Т. Н. Владимирова, Н. Ю. Лесконог, 2022 
Заключение. Полученные результаты могут быть использованы органами государственной власти субъектов Российской Федерачии, федеральных округов Российской Федераџии, образовательными организациями выстего образования для повышения эффективности функиионирования региональных моделей подготовки педагогических кадров, интеграции их в единое образовательное пространство подготовки педагогических кадров России. Рассмотренный $в$ статье и апробированный в ходе исследования паспорт описания модели региональной подготовки педагогических кадров может быть предложен в качестве типового.

Ключевые слова: региональная модель подготовки педагогических кадров; паспорт модели; педагогические классы; наставничество; педагогический кластер; педагогические кадры; технопарк; непрерывное педагогическое образование.

\section{Постановка проблемы}

Стратегия современного педагогического образования нацелена на подготовку педагогических кадров, способных не только обеспечивать качественный образовательный процесс, но и содействовать формированию высоконравственной, креативной, конкурентноспособной личности, обладающей развитым интеллектом и устойчивой гражданской позицией.

Развитие педагогической системы учебных заведений сопровождается внедрением инновационных изменений в педагогическую практику, реализуемых руководителями школ, творческими учителями, и требует новых методов воздействия, одним из которых является моделирование, выступающее в современных условиях универсальным методом внедрения инновационных процессов в практику подготовки педагогических кадров в субъектах Российской Федерации.

Вызовы XXI века ставят перед российской системой подготовки педагогических кадров достижение к 2030 году целевого показателя «вхождение Российской Федерации в

\footnotetext{
${ }^{1}$ Указ Президента Российской Федерации «О национальных целях развития Российской Федерации на период до 2030 года» № 474 от 21.07.2020.

2 Вербицкая Л. А., Касевич В. Б. О модернизации российской высшей школы: сегодняшние проблемы и
}

число десяти ведущих стран мира по качеству общего образования» для обеспечения прорывного развития страны ${ }^{1}$. Это, в свою очередь, требует от российской системы высшего педагогического образования разработки и внедрения современных региональных моделей подготовки педагогических кадров.

Отечественные исследователи неоднократно рассматривали проблемы, характерные для систем региональных моделей подготовки педагогических кадров (А. М. Елисеева [1], А. М. Осипов, Н. А. Матвеева, П. А. Бояджиева, Я. А. Воронцов [2]).

В работах российских ученых проблемы моделирования региональных систем образования рассматриваются как правило через призму модернизации процессов в высшей школе (Л. А. Вербицкая, В. Б. Касевич ${ }^{2}$; Е. А. Сакалова ${ }^{3}$; Н. Н. Давыдова, Б. М. Игошев, С. Л. Фоменко [3]).

При исследовании различных подходов к моделированию в педагогическом образовании следует отметить, что зарубежные авторы также изучают проблемы моделирования в образовательной среде. Так, исследователями

возможные решения // Вопросы образования. 2004. - № 4. - С. 10-20.

${ }^{3}$ Сакалова Е. А. Модель управления вузом в условиях модернизации российского образования: обоснование конкурентного позиционирования: автореф. канд. соц. наук: 22.00.08. - Ростов-на-Дону, 2011. 
выявляется роль высших учебных заведений в построении региональных инновационных систем (M. C. J. Caniëls, H. van den Bosch [4]); определяются особенности разработки региональной образовательной программы для поддержки структурированного обучения (J. M. Mrcog [5]); акцентируется внимание на вопросах согласованности моделей различных уровней и содержания (R. J. Chiang, W. Meagher, S. Slade [6]), определяются региональные различия образовательных моделей (S. Gamsu, M. Donnelly [7]).

Отдельное внимание уделяется исследователями вопросу развития одаренности через различные теоретические модели (D. R. Clasen, M. Hanson [8]).

В исследованиях зарубежных авторов также рассматриваются проблемы формирования теоретической модели наставничества и педагогической интернатуры (K. D. Besnoy, S. C. McDaniel [9]; A. E. Donlan, E. R. McDermott, J. F. Zaff [10]).

Рассматривая модели развития педагогических кластеров, исследовательский коллектив (Л. Ю. Грачева, Э. Р. Баграмян, М. Н. Цыганкова, Т. Ц. Дугарова, Н. Н. Шевелева [11]) изучал механизмы мультипрофессионального сотрудничества в Финляндии в рамках STEMобразования, где в период с 1996 по 2002 год Национальный совет научного образования

\footnotetext{
${ }^{4}$ Korhonen T., Lavonen J., Kukkonen M., Sormunen K., Juuti, K. The Innovative School as an Environment for the Design of Educational Innovations // Finnish Innovations \& Technologies in Schools: Towards New Ecosystems of Learning / H. Niemi, J. Multisilta, L. Lipponen, M. Vivitsou (Eds.). Rotterdam, NL. Sense Publishers. 2014. - Р. 38-56.

${ }^{5}$ Гершунский Б. С. Философско-методологические основания стратегии развития образования в России; Рос. акад. образования, Ин-т теорет. педагогики и междунар. исслед. в образовании. - М., 1993.

${ }^{6}$ Кирсанов А. А. Методологические проблемы создания прогностической модели специалиста. - Казань,

координировал программу LUMA (H. Niemi et. al. ${ }^{4}$ [12]), в результате реализации которой с 2003 по 2018 год было создано 13 LUMAцентров, среди которых Центр LUMA Finland выступает в качестве зонтичной организации всех центров LUMA в финских университетах и университетских городках для укрепления и продвижения их сотрудничества на национальном и международном уровнях [11].

В исследовании [11] также показано, что к проблемам моделирования практики профессионального развития учителей обращаются китайские исследователи [13; 14] при изучении культуры конфуцианского наследия студентами и преподавателями в Гонконге.

Цель настоящего исследования - выявление особенностей современных региональных моделей подготовки педагогических кадров с помощью метода системного моделирования.

\section{Методология исследования}

Методологические основы исследования состояния региональных моделей подготовки педагогических кадров в субъектах Российской Федерации составили концепция непрерывного образования (Б. С. Гершунский ${ }^{5}$, А. А. Кирсанов ${ }^{6}$, В. Ш. Масленникова ${ }^{7}$ и др.), педагогические положения о моделировании

2000. - 227 c. ISBN 5-7882-0163-2 URL: https://search.rsl.ru/ru/record/01000697080

${ }^{7}$ Опыт и проблемы профессиональной подготовки специалистов социальной сферы в образовательных учреждениях муниципальных образований Республики Татарстан: материалы региональной научно-практической конференции / Акад. социального образования (КСЮИ), Буинский фил. Акад. социального образования (КСЮИ), Органы местного самоуправления Буинского муниципального р-на Республики Татарстан; ред. В. Ш. Масленникова и др. - Казань: Отечество, 2008. - 283 c. ISBN 978-5-9222-0257 URL: https://search.rsl.ru/ru/record/01004323784 
образовательного процесса (В. И. Гинецинский [15], Н. Н. Кузьмина, В. Н. Софьина ${ }^{8}$, В. В. Беспалова, Г. Е. Муравьева $\left.{ }^{9}\right)$.

В рамках проведенного научного исследования в качестве ведущего метода был применен метод сравнительно-сопоставительного анализа региональных моделей подготовки педагогических кадров.

В качестве определения понятия «модель» принята формулировка: «Модель - это форма отображения определенного фрагмента действительности (предмета, явления, процесса, ситуации) - оригинала модели, которое содержит существенные свойства моделируемого объекта и может быть представлено в абстрактной (мысленной или знаковой) или материальной (предметной) форме» (В. С. Стёпин, А. А. Ивин, Ф. Н. Голдберг $)^{10}$.

Авторы согласны с точкой зрения Е. Н. Землянской, которая считает, что «более глубокое толкование слова „модель“ предполагает, что основное внимание уделяется моделированию скрытых внутренних свойств объекта» [16, с. 36].

Существуют различные классификации моделей исследования социальных процессов:

a) понятийная, отражающая знания об объекте в форме определенной совокупности взаимосвязанных положений, утверждений, выводов;

б) образная, воспроизводящая основные стороны, элементы, связи, отношения объекта

\footnotetext{
${ }^{8}$ Кузьмина Н. В., Софьина В. Н. Акмеологическая концепция развития профессиональной компетентности в вузе: монография; Федеральное гос. образовательное учреждение высш. проф. образования РФ, Российская Акад. Образования, Смольный ин-т РАО, Ин-т пед. образования РАО. - Санкт-Петербург: Центр стратегических исслед., 2012. - 199 с. ISBN 978-5-98994-041-7

URL: https://search.rsl.ru/ru/record/01006631400

${ }^{9}$ Беспалова В. В., Муравьева Г. Е. Разработка технологии проектирования образовательного процесса в

в форме описаний, фото- и киномоделей, графиков, схем;

в) знаково-символическая (математическая), отражающая существенные внутренние и внешние связи и отношения оригинала в виде формулы;

г) физическая, отображающая структуру и функции объекта в пространстве (Л. М. Фридман $)^{11}$.

В рамках изучения региональных моделей педагогического образования исследовательский коллектив обратился к методологии изучения статической модели, которая отображает несколько компонентов состояния исследуемых объектов:

- концептуально-целевой (включающий цели, задачи, идеи, принципы исследуемого процесса);

- содержательный (виды, сферы, направления деятельности);

- процессуальный или операционно-деятельностный (технологии, формы, методы, средства);

- аналитико-результативный (критерии и показатели развития исследуемого процесса, методики и способы их замера, средства аналитической деятельности) (Л. М. Фридман) $)^{12}$.

Региональные системы подготовки педагогических кадров в Российской Федерации отличаются существенным многообразием, неисчерпаемостью творческих подходов и своеобразием отражения как исторических

вузе на основе компетентного подхода // Преподаватель XXI век. - 2011. - № 2.

${ }^{10}$ Стёпин В. С., Ивин А. А., Голдберг Ф. Н. Подготовка электронной публикации и общая редакция: Центр гуманитарных технологий. URL: https://gtmarket.ru/concepts/7024

11 Фридман Л. М. Наглядность и моделирование в обучении. - М.: Знание, 1984. - С. 25-26. URL: https://search.rsl.ru/ru/record/01001204842

12 Там же. 
традиций, так и местных, национальных особенностей при наличии единой системы стандартизации образовательного процесса.

Применение метода моделирования позволяет исследовать региональные системы подготовки педагогических кадров, при этом выделить в них системообразующие субъекты, преобладающие тенденции, наиболее существенные связи между субъектами образовательного процесса, характерные направления деятельности подготовки педагогических кадров, отражающие наиболее значимые и характерные черты.

Для опроса представителей органов управления образовательных организаций высшего образования была спроектирована стратифицированная выборка. Основным признаком отбора единиц генеральной совокупности для проведения опроса является реализация образовательной организацией основных образовательных программ бакалавриата и магистратуры по направлению УГСН 44.00.00 «Образование и педагогические науки». Таким образом, было отобрано 240 образовательных организаций высшего образования во всех федеральных округах Российской Федерации, которые расположены во всех субъектах Российской Федерации, кроме 3, в которых подобные образовательные организации высшего образования отсутствуют (Ненецкий АО, Ямало-Ненецкий АО, Чукотский АО). На следующем этапе был применен простой случайный отбор, в результате которого в опросе приняли участие представители 41 организации, из которых 27 вузов, подведомственных Министерству просвещения РФ и являющихся ресурсными центрами в системе подготовки педагогических кадров.

Фокус-группа была сформирована по случайному признаку из участников Всероссийского педагогического форума «Учитель - будущее России». Количество участников фокус-группы более 15 человек.

К экспертному опросу было привлечено 50 высококвалифицированных представителей - специалистов руководящего и профессорско-преподавательского состава организаций высшего и среднего профессионального образования, общеобразовательных организаций и организаций дополнительного образования, организаций отдыха и оздоровления детей из всех федеральных округов Российской Федерации. Одним из условий было наличие стажа в занимаемой должности не менее трех лет.

Обсуждение состояния региональных систем подготовки педагогических кадров на круглых столах во всех восьми федеральных округах показало многообразие моделей и подходов к их применению. На круглых столах, проведенных научным коллективом научно-исследовательской работы «Сравнительный анализ моделей региональных систем подготовки педагогических кадров на примере 8 федеральных округов Российской Федерации и особенности взаимодействия федеральных и региональных участников образовательного процесса», выполняемой МПГУ по заказу Министерства просвещения России, свои модели представили более 70 спикеров. С целью придания единообразия описанию региональных моделей авторами статьи был разработан типовой паспорт описания региональной модели подготовки педагогических кадров во взаимодействии федеральных и региональных участников образовательного процесса. По итогам паспортизации моделей было собрано 11 паспортов, по одному-два паспорта от каждого федерального округа.

Структура Паспорта модели, предложенная исследовательским коллективом, включает в себя следующие разделы. 


\section{1. Наименование модели.}

В идеале каждая модель должна иметь свое название. Например, модель региональной системы подготовки педагогических кадров во взаимодействии федеральных и региональных участников образовательного процесса «Открытая межрегиональная модель подготовки лидеров образования для XXI века», разработанная ФГАОУ ВО «Южный федеральный университет» и реализуемая в Южном федеральном округе. Но нередко представленные для анализа модели не содержат оригинального названия. Разработчики обозначают ее как модель подготовки педагогических кадров конкретного региона. Например, модель региональной подготовки педагогических кадров Ставропольского края во взаимодействии федеральных и региональных участников образовательного процесса, разработанная Ставропольским филиалом ФГБОУ ВО «Московский педагогический государственный университет» и реализуемая в Северо-Кавказском федеральном округе.

2. Когда и кем разработана модель, каким документом утверждена, сроки реализации модели.

В этом разделе авторы статьи просили указать разработчиков модели нормативные акты, которыми она утверждена. И здесь наши предположения подтвердились: по большей части опыт есть, но документально он не зафиксирован. Авторы-разработчики модели часто не указаны. Тем не менее выявлена и положительная динамика. Например, модель региональной системы подготовки педагогических кадров в Алтайском крае, разработанная Алтайским государственным педагогическим университетом, реализуется в рамках соглашения между министерством образования и науки Алтайского края и ФГБОУ ВО «Алтайский государственный педагогический уни- верситет» от 12 марта 2021 г. Модель, представленная ФГБОУ ВО «Московский педагогический государственный университет», peaлизуется в рамках соглашения с ГАУ СО МО «Социально-оздоровительный центр «Лесная поляна» - учреждения, подведомственного министерству социального развития Московской области. Соглашение подписано в рамках ежегодного подмосковного форума в январе 2018 г.

Модель, представленная ФГБОУ ВО «Российский государственный педагогический университет им. А. И. Герцена» и реализуемая в Северо-Западном федеральном округе, содержит указание на конкретных авторов-разработчиков, так же как и модель, представленная ФГБОУ ВО «Московский педагогический государственный университет».

3. Цель модели.

Традиционный пункт любого документа. Разработчики, описывая цели своих моделей, указывали во исполнение каких нормативноправовых документов федерального и регионального уровня они реализуется.

4. Задачи реализации модели.

Специфика региональных моделей начинает формироваться как раз на уровне определения задач достижения целевых ориентиров.

5. Актуальность реализации модели.

В актуальности разработчики описывали, на какие глобальные вызовы, стоящие перед Россией, на реализацию каких стратегических инициатив региона направлена данная модель.

6. Участники модели - субъекты региональной системь подготовки педагогических кадров, участвующие в реализачии модели.

Нужно отметить, что все разработчики достаточно детально составили перечень субъектов, участвующих в реализации модели, их роль и функционал в рамках модели как на федеральном, так и на региональном 
уровнях. Это говорит о хорошем управленческом потенциале предложенных моделей. Например, в модели, представленной Институтом педагогики и психологии ФГБОУ ВО «Костромской государственный университет» и реализуемой в Центральном федеральном округе, четко обозначены субъекты образовательного процесса, реализующие данную модель. Так, на уровне субъекта Российской Федерации - администрация Костромской области, департамент образования и науки Костромской области. На уровне муниципалитетов - комитет образования, культуры, спорта и работы с молодежью г. Костромы, отделы образования муниципальных районов и городских округов Костромской области. На уровне учреждений: федеральном - ФГБОУ ВО «Костромской государственный университет»; региональном - ОГБОУ ДПО «Костромской областной институт развития образования»; городском - МБО г. Костромы «Городской центр обеспечения качества образования». На уровне образовательных организаций - образовательные организации дошкольного, общего, среднего профессионального образования г. Костромы и Костромской области.

7. Краткое описание, основные принципь, структура и механизмь взаимодействия участников модели.

В этом разделе разработчики рассматривают возможности сетевого взаимодействия между участниками модели - субъектами региональной системы подготовки педагогических кадров во взаимодействии с федеральными участниками образовательного процесса; возможности межведомственного взаимодействия; механизмы совместного планирования и принятия решений, в том числе на федеральном и региональном уровнях, необходимых для реализации модели, а также возможности использования при подготовке пе- дагогов ресурсов всероссийских детских центров, общественных объединений, организаций отдыха и оздоровления, кванториумов, технопарков и др. Приятно отметить, что практически во всех моделях представлен опыт сотрудничества и/или сетевого взаимодействия с такими федеральными детскими центрами, как МДЦ «Артек», ВДЦ «Орленок», ВДЦ «Океан», ВДЦ «Смена» и образовательным центром «Сириус».

Опыт использования педагогического технопарка отражен в модели, представленной ФГБОУ ВО «Уральский государственный педагогический университет» и реализуемой в Уральском федеральном округе.

Предметом нашего исследования и, соответственно, разделами паспорта модели стали также следующие параметры.

8. Основные направления деятельности в рамках реализации модели, в том числе на региональном и федеральном уровнях.

9. Ожидаемые и полученные результаты реализации модели, в том числе на региональном и федеральном уровнях.

10. Информационно-медийное сопровождение модели.

\section{1. Финансирование.}

12. Показатели оченки эффективности модели. (Примечание: просим дать описание критериев и/или индикаторов и/или показателей, используемых при оченке эффективности модели, а также указать, есть ли официальный документ, которым утвержден данный перечень критериев оченки модели.)

13. Нормативные документы, в том числе федерального и регионального уровней, обеспечивающие реализачию модели и контроль за ее результатами.

\section{4. Приложения.}

Формат научной статьи не позволяет детально рассмотреть и расшифровать все 
пункты паспорта. Выборочно представим содержательные результаты исследования.

\section{Результаты исследования}

Российская система подготовки педагогических кадров отличается самобытностью, высоким уровнем практико-ориентированности, разнообразием целевых, содержательных, инструментальных характеристик. Ориентирами разнообразных моделей являются Федеральные государственные образовательные стандарты высшего образования по направлениям подготовки 44.00.00 «Образование и педагогические науки» и Профессиональный стандарт «Педагог (педагогическая деятельность в сфере дошкольного, начального общего, основного общего, среднего общего образования) (воспитатель, учитель)», утвержденного Приказом Минтруда России № 544н от 18.10.2013 г.

Тем не менее в рамках исследования удалось выявить наиболее распространенные модели подготовки педагогических кадров, реализуемые в разных федеральных округах нашей страны. В данной статье рассмотрим четыре из них.

\section{1. Модель «Подготовка вожатских кад-} ров как основа подготовки педагогчческих кадров к воспитательной работе с детьми». Вожатская подготовка будущих педагогов к воспитательной работе с детьми, к созданию воспитывающей среды в образовательных организациях, организациях отдыха и оздоровления рассматривается как уникальная возможность формирования метапредметных компетенций будущих учителей через реализацию дисциплины «Основы вожатской деятельности» и летнюю педагогическую (вожатскую) практику. Они реализуются благодаря деятельности Федерального координационного центра по подготовке и сопровождению вожатских кадров МПГУ в абсолютном большинстве вузов, занимающихся подготовкой учителей, независимо от ведомственного подчинения (в том числе в 31 из 33 педагогических вузов, подведомственных Министерству просвещения России), о чем неоднократно писали представители исследовательского коллектива [17; 18; 19].

Данный опыт отражен в абсолютном большинстве представленных паспортов, что является свидетельством системной работы МПГУ с 2017 года по включению модуля «Основы вожатской деятельности» в основные образовательные программы УГСН 44.00 .00 «Образование и педагогические науки».

Тем не менее наибольший акцент на подготовке вожатых сделан специалистами ФГБОУ ВО «Московский педагогический государственный университет» и ФГБОУ ВО «Костромской государственный университет» (Центральный федеральный округ), ФГБОУ $\mathrm{BO}$ «Ульяновский государственный педагогический университет им. И. Н. Ульянова» (Приволжский федеральный округ), ФГБОУ ВО «Российский государственный педагогический университет им. А. И. Герцена» (СевероЗападный федеральный округ).

2. Модель «Педагогчческие классы для допрофессиональной подготовки и профессиональной ориентации обучающихся». Допрофессиональная подготовка будущих педагогов через систему педагогических классов, базовых школ и предуниверсариев чрезвычайно актуальна среди участников исследования. Спикеры, выступающие на круглых столах, неоднократно отмечали, что в их организациях в работу педагогических классов активно вовлечены студенты-вожатые из педагогических вузов. По результатам опроса 365 старшеклассников, обучающихся в педагогиче- 
ских классах в пяти регионах Российской Федерации, 30,4 \% из них записались в педагогический класс самостоятельно, чтобы понять сущность работы педагога; 28,1 \% - записались из любопытства; 18,8 \% - записались в педагогический класс, так как планируют поступать в педагогический вуз (рисунок1).

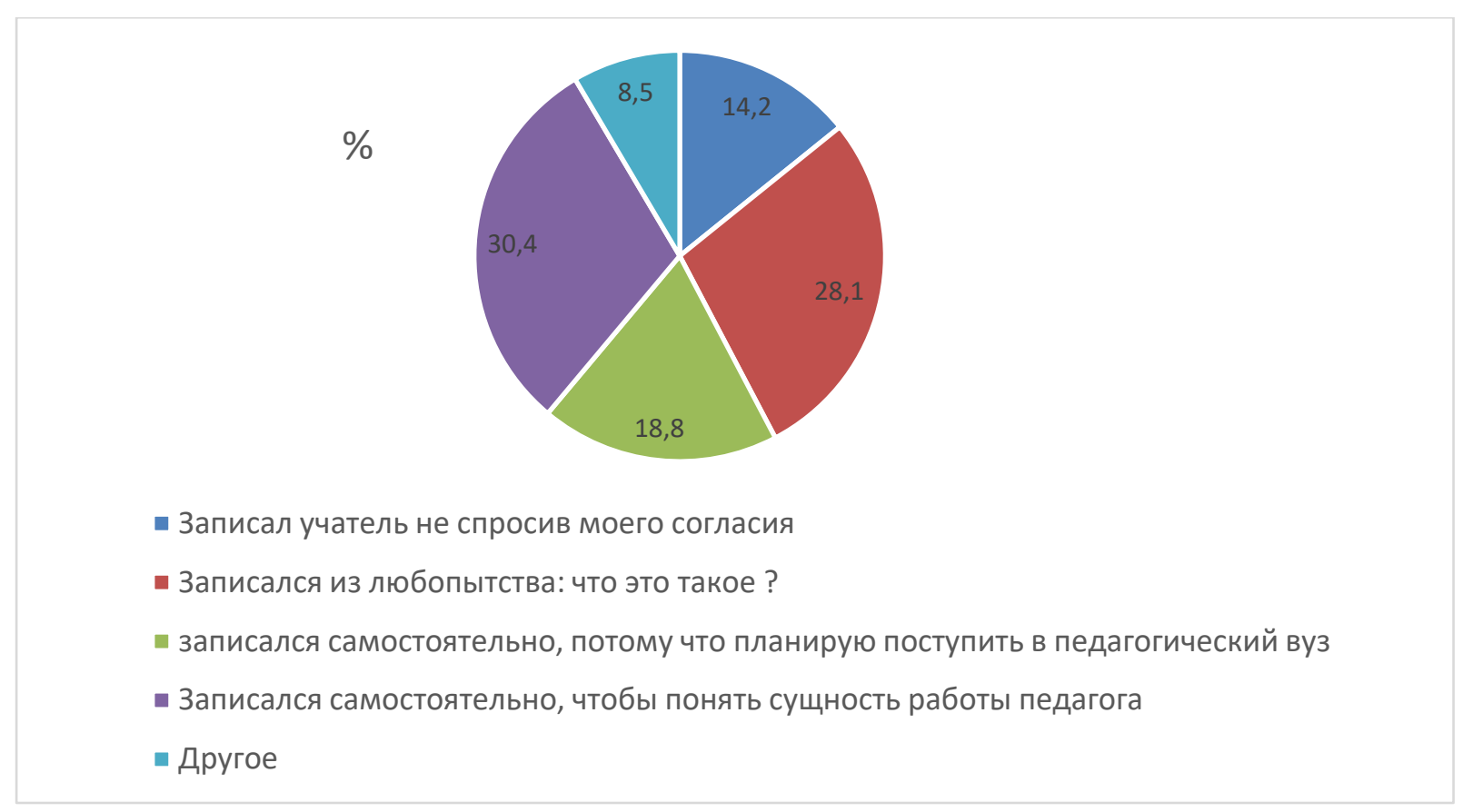

Puc. 1. Ответы респондентов на вопрос «Как вы стали участником педагогического класса?»

Fig. 1. Respondents' answers to the question "How did you become a member of the pedagogical class?"

На вопрос о том, что привлекает в программе занятий педагогического класса ${ }^{13}$ (рисунок 2), 44,9 \% респондентов отметили возможность развивать разговорную речь (это самый популярный ответ), 44,3 \% - пришли в педагогический класс, чтобы расширить свой кругозор, 41,3 \% - для творческого самовыражения. Интересно, при общении с первокурсниками МПГУ, которые не учились в педагогических классах, но сразу после поступления в педагогический университет записались в

\footnotetext{
${ }^{13}$ На данный вопрос предлагалось выбрать неограниченное количество ответов.

${ }^{14}$ Опрос проводился среди 365 школьников - участников педагогических классов из Москвы, Волгоградской, Костромской, Астраханской, Ростовской областей в рамках НИР «Сравнительный анализ моделей

Школу вожатых МПГУ, мы выявили точно такие же ожидания от обучения в вузе. То есть те же самые дефициты, которые вполне может восполнить программа педагогического класса еще до поступления в вуз ${ }^{14}$.

Больше всего в деятельности педагогических классов старшеклассников привлекает три позиции: расширение своего кругозора (44,3 \%), возможность развивать разговорную речь $(44,9 \%)$ возможность творческого самовыражения (41,3 \%). Только треть из всех

региональных систем подготовки педагогических кадров на примере 8 федеральных округов Российской Федерации и особенности взаимодействия федеральных и региональных участников образовательного процесса». 
участников $(32,4 \%)$ отметили в качестве привлекательного фактора возможность лучше понять свои профессиональные интересы.

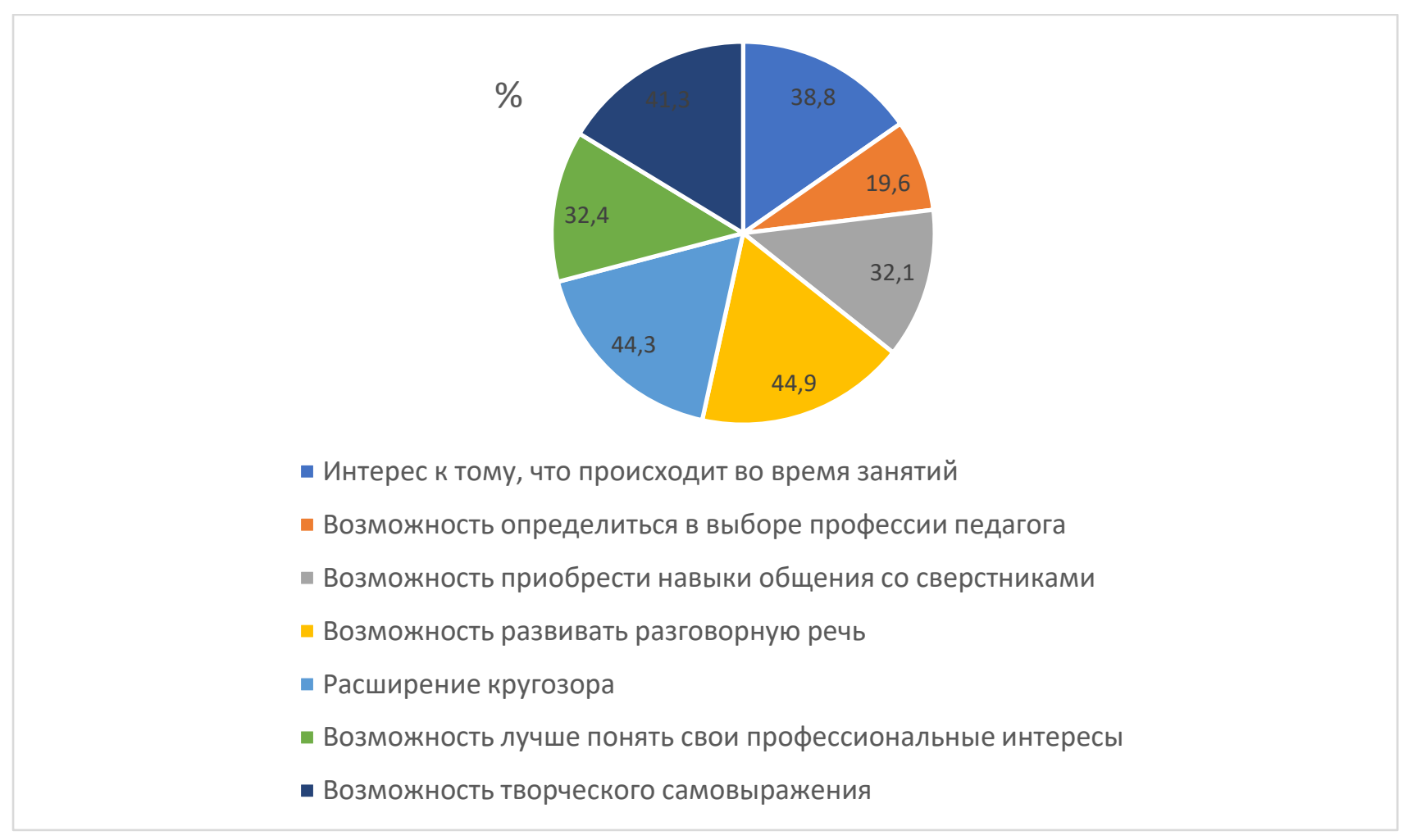

Puc. 2. Ответы респондентов на вопрос «Что вас привлекает в программе занятий педагогического класса?» Fig. 2. Respondents' answers to the question "What attracts you in the curriculum of the pedagogical class?"

В программе занятий педагогических классов школьники хотели бы видеть больше творческих мероприятий (36,5 \%), больше бесед о мечте и смысле жизни (35,9 \%), диагностику свойств личности участников педагогических классов (30,1\%). 29,1 \% респондентов хотел бы получить возможность попробовать себя в роли учителя и каждый пятый - поработать вожатым младших классов в своей школе ${ }^{15}$ (рисунок 3 ).

\footnotetext{
${ }^{15}$ На данный вопрос предлагалось выбрать неограниченное количество ответов.
} 


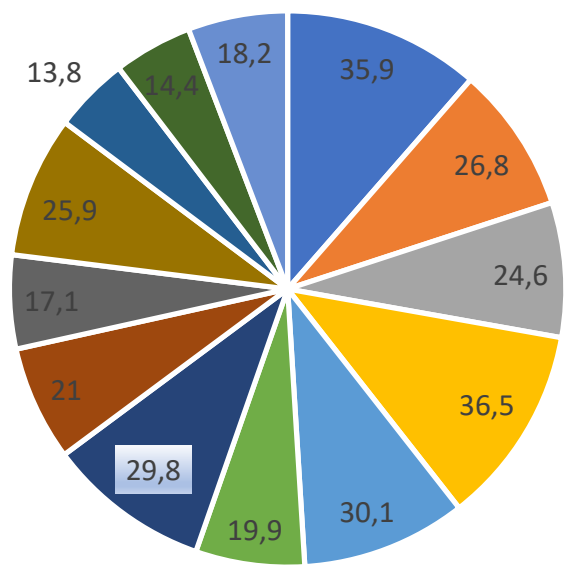

- Больше бесед о мечте и смысле жизни

- Интеллектуальные квесты по тематике педагогического класса

- Ситуационные ролевые игры

- Творческие мероприятия

• Диагностика свойств личности участника педкласса

- Разработка проектов и их реализация в школе

- Возможноть ппробовать себя в роли учителя

- Работа вожатыми в младших классах

- Встречи со студентами педвуза

Puc. 3. Ответы респондентов на вопрос «Что бы вам хотелось добавить в программу работы педагогического класса?»

Fig. 3. Respondents' answers to the question "What would you like to add to the work program of the pedagogical class?"

Среди участников исследования взаимодействие с педагогическими классами отразили в паспортах моделей ФГБОУ ВО «Волгоградский государственный социально-педагогический университет» (Южный федеральный округ), Институт педагогики и психологии ФГБОУ ВО «Костромской государственный университет» и ФГБОУ ВО «Московский педагогический государственный университет» (Центральный федеральный округ), ФГБОУ
ВО «Тихоокеанский государственный университет» (Дальневосточный федеральный округ) и др.

3. Модель «Педагогическая интернаmура». Спикеры на круглых столах и эксперты, проинтервьюированные в ходе исследования, однозначно рассматривают наставничество как востребованную модель как во время обучения студентов в вузе, так и после него, в том числе в формате педагогической 
интернатуры. Следует отметить, что по результатам опроса исполнительных органов власти, осуществляющих государственное управление в сфере образования субъекта Российской Федерации, $60 \%$ участников опроса (35 органов власти) отметили, что в регионе разработана система наставничества для молодых педагогов ${ }^{16}$. Еще в 18 регионах (31\% респондентов) она находится в стадии формирования.
Важным представлялось выявить мнение студенческой молодежи о необходимости внедрения систем наставничества для молодых педагогов. С этой целью в опрос студентов ${ }^{17}$ были включены несколько вопросов. Абсолютное большинство респондентов 70,2 \% (2286 человек) уверены, что закрепление наставника за молодым педагогом положительно повлияет на улучшение качества его труда (рисунок 4).

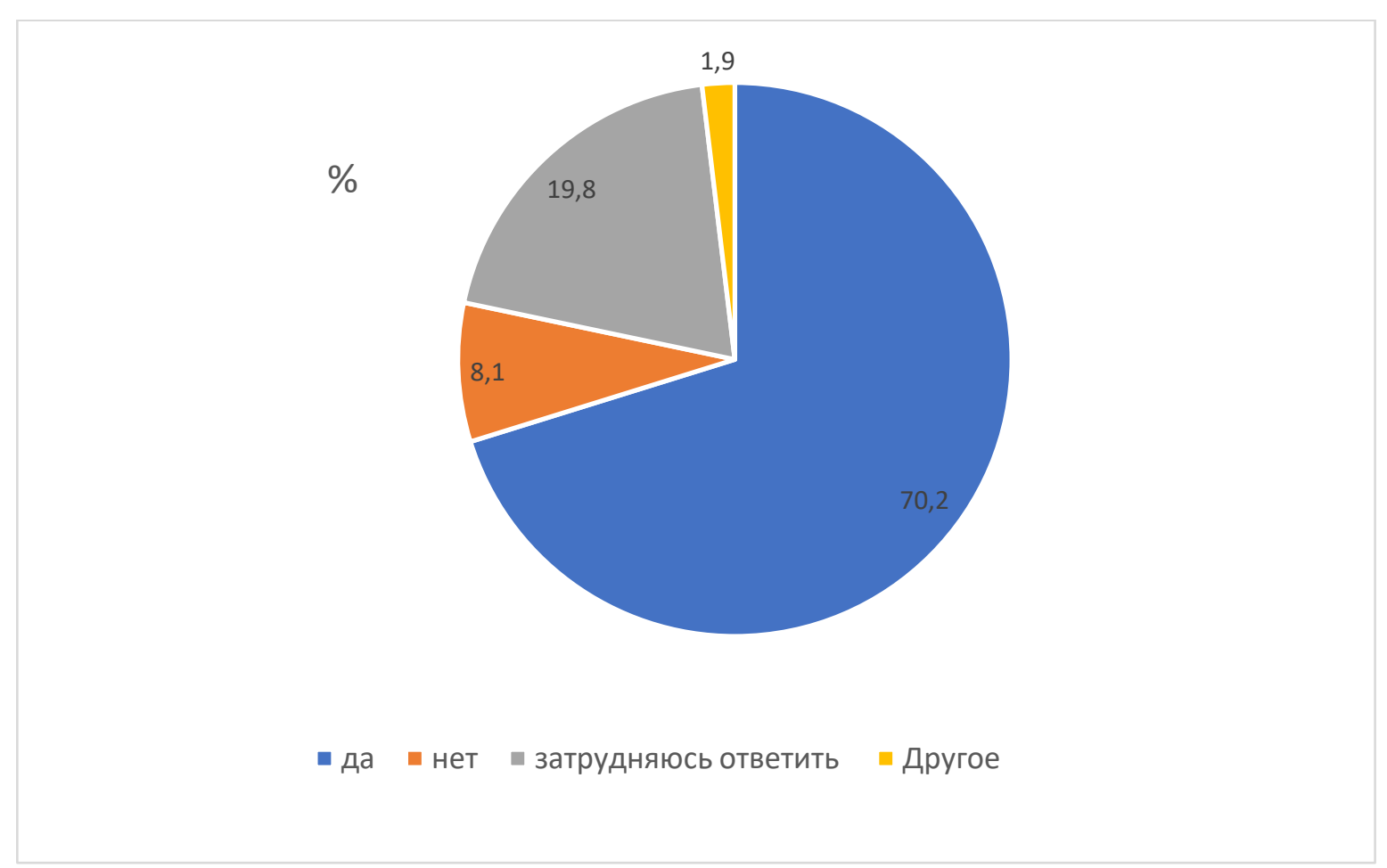

Puc. 4. Ответы студентов на вопрос «Повлияет ли на улучшение качества труда молодого педагога закрепление за ним наставника?»

Fig. 4. Students' answers to the question "Will the assignment of a mentor to a young teacher affect the improvement of the quality of work?"

Только 1,6 \% респондентов отметили, что, по их мнению, такая помощь молодым педагогам не нужна. А вот о периоде, когда

\footnotetext{
${ }^{16}$ В опросе, проведенном авторами в сентябре - октябре 2021 г., приняли участие 58 органов исполнительной власти, осуществляющих государственное
}

необходима наибольшая помощь молодым специалистам, мнения участников опроса разделились:

управление в сфере образования субъекта Российской Федерации.

${ }^{17}$ В опросе приняли участие 3365 студентов из 51 вуза всех федеральных округов РФ. 
$43 \%$ респондентов считают, что им помощь нужна будет в первый год работы, $32 \%$ отмечают, что такая помощь нужна в первые полгода, оставшиеся 22,6 \% предпочитают, чтобы помощь оказывалась в первый месяц работы (рисунок 5).

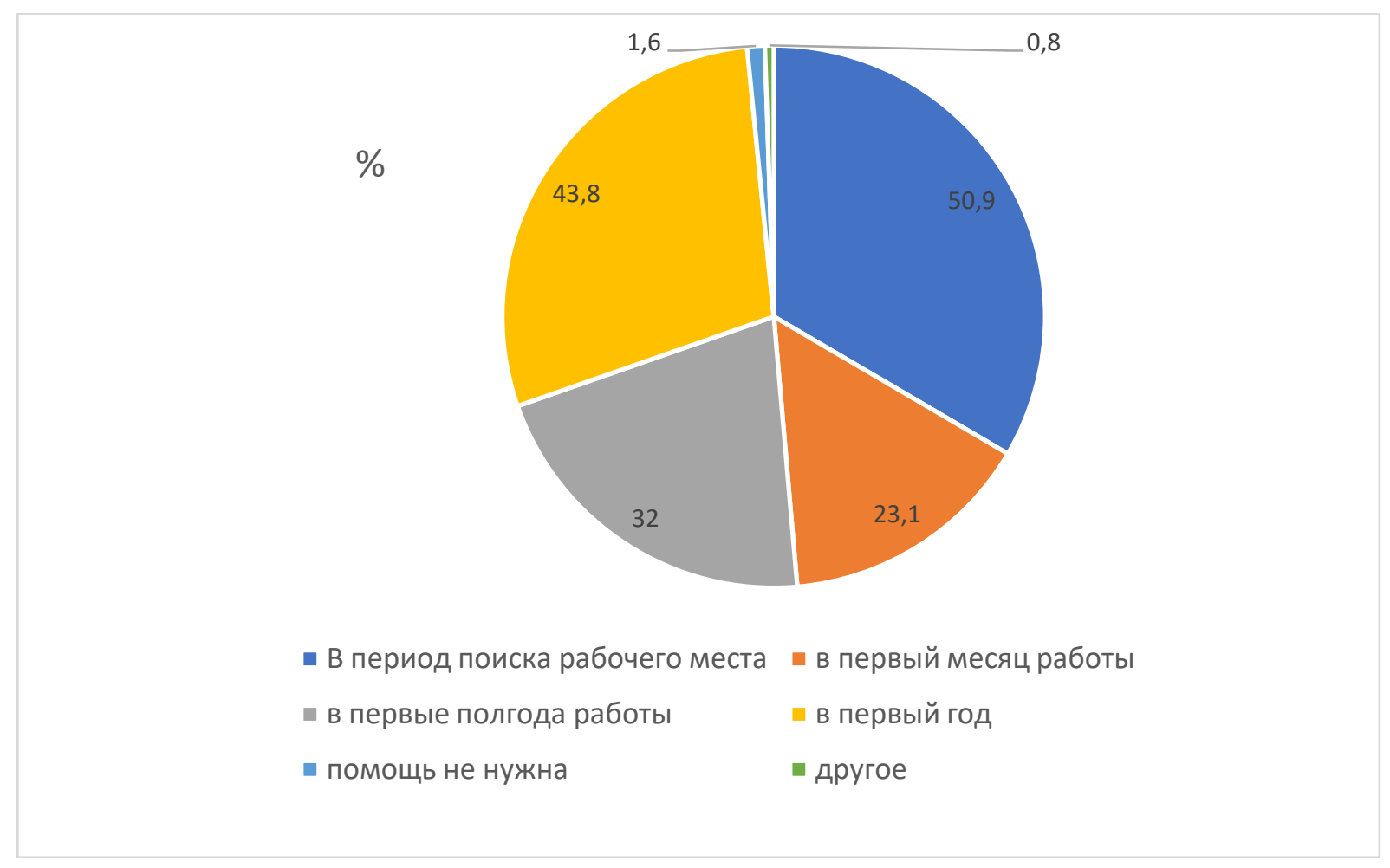

Puc. 5. Ответы студентов на вопрос «В какой период молодым специалистам наиболее необходима помощь наставника?»

Fig. 5. Students' answers to the question "In what period do young professionals most need the help of a mentor?"

Таким образом, студенческая молодежь идею формирования систем наставничества поддерживает.

Идеи наставничества и педагогической интернатуры отражены в паспортах моделей, представленных ФГБОУ ВО «Уральский государственный педагогический университет» (Уральский федеральный округ), ФГБОУ ВО «Тихоокеанский государственный университет» (Дальневосточный федеральный округ), Ставропольским филиалом ФГБОУ ВО «Московский педагогический государственный университет» (Северо-Кавказский федеральный округ).
4. Модель «Двухпрофильный бакалавриат». Эта модель востребована в регионах, где есть проблемы с трудоустройством. Молодые специалисты, имеющие две квалификации, более востребованы на рынке труда, могут работать в образовательных организациях более чем на одну ставку. Например, спикеры на круглых столах в Сибирском и Северо-Кавказском федеральных округах озвучили данную модель как жизненную необходимость для регионов, входящих в их округа. Эту модель используют в своей работе ФГБОУ ВО «Алтайский государственный педагогический университет» и ФГБОУ ВО «Омский государственный педагогический 
университет» (Сибирский федеральный округ), Ставропольский филиал ФГБОУ ВО «Московский педагогический государственный университет» (Северо-Кавказский федеральный округ).

В рамках исследования были определены и наиболее перспективные модели региональных систем подготовки педагогических кадров во взаимодействии федеральных и региональных участников образовательного процесса. В современных условиях к ним следует отнести следующие модели.

Модель непрерывного педагогического образования (представлена в паспортах ФГБОУ ВО «Волгоградский государственный социально-педагогический университет» (Южный федеральный округ), Института педагогики и психологии ФГБОУ ВО «Костромской государственный университет» (Центральный федеральный округ)).

Заслуживает внимания деятельность многих образовательных организаций высшего образования по реализации данной модели.

Так, ФГАОУ ВО «Дальневосточный федеральный университет» (ДВФУ) в системе дополнительного профессионального образования реализует персонифицированную накопительную модель повышения квалификации, которая предполагает предоставление каждому слушателю возможности выбора содержания программы в соответствии с его образовательными потребностями. Слушатель сам конструирует программу повышения квалификации путем выбора практико-ориентированных семинаров (очных и дистанционных) как модулей программы.

Программы профессиональной переподготовки построены по модульному принципу. При этом используется вариативная модель, которая позволяет менять векторы программы, предоставлять слушателю возможность выбора модулей с учетом уровня базовой подготовки, наличия педагогического образования, выбранного профиля подготовки.

Поддержка и сопровождение педагогических работников осуществляется в ДВФУ путем предоставления актуального перечня программ повышения квалификации, семинаров и вебинаров, соответствующих потребностям педагогов. Потребности педагогов изучаются посредством мониторингов, непосредственного общения, контактов с представителями органов управления образованием.

Создан методический семинар для молодых педагогов, через который осуществляется поддержка и сопровождение выпускников. Занятия семинара проходят с учетом запросов молодых педагогов. Ведется работа с управлениями образования муниципальных образований с целью выявления потребностей и трудностей молодых педагогов. В рамках семинара осуществляются различные формы взаимодействия с молодыми педагогами: фронтальные, групповые (работа в малых группах), индивидуальные (индивидуальное консультирование по запросу молодого педагога).

В ФГБОУ ВО «Нижегородский государственный педагогический университет имени Козьмы Минина» создана система центров непрерывного образования: центр непрерывного повышения профессионального мастерства педагогических работников и центр научнометодического сопровождения педагогических работников.

В ФГБОУ ВО «Чеченский государственный педагогический университет» разработаны модели гибкой многоуровневой и многоканальной подготовки педагогических работников, применяющих новые формы педагогической и воспитательной деятельности. 
Здесь созданы педагогическая мастерская Алихана Динаева, Центр продуктивного образования «Эковерситет», художественная мастерская А. Бугаева, которые объединены в единое пространство неформального образования «Open space» и ориентированы на формирование и развитие метанавыков у студентов и научно-педагогических работников вуза. Реализуется программа наставничества «студент-ученик», обеспечивающая формирование и развитие у студентов профессиональных навыков.

В Курске в Институте непрерывного образования реализуются следующие инновационные модели: модульно-накопительная, персонализированная, реализуемые в условиях федеральной инновационной площадки «Методика персонализированного обновления и повышения уровня профессиональной компетентности педагогов в условиях цифровой трансформации ДПО». Модель многоуровневой подготовки педагогических кадров к профессиональной деятельности разработана с опорой на базовые типы педагогических моделей Е. А. Лодатко с учетом структуры исследуемого объекта (многоуровневая система), соответствующих для нее связей (педагог - содержание - обучающийся; обучающийся обучающийся - педагог - обучающиеся...), содержания (изучение дидактических особенностей элементов и ресурсов, целеполагание, планирование, выбор цифрового инструментария, построение технологии организации обучения), функциональности (ориентация на реализацию педагогически значимых функций - целеполагания, диагностической, проективной, планирования, организационной и др.) и дополнена неотъемлемыми компонен- тами разработанной системы подготовки: динамичностью (конкретные, развивающиеся и обновляющиеся формы и технологии реализации) и средствами реализации.

С учетом признания значимости развития системы непрерывного педагогического образования в опросе представителей образовательных организаций высшего образования ${ }^{18}$ был задан вопрос о том, какие элементы нашли отражение в системе непрерывного педагогического образования в регионе и в вузе. По данным ответам выстроился рейтинг наиболее распространенных элементов:

- создание условий для вовлечения педагогических работников в исследовательскую деятельность $(77,5 \%)$;

- развитие сетевого взаимодействия между субъектами научно-методической деятельности для создания единой информационно-методической среды, способствующей профессиональному росту педагогических работников и управленческих кадров (50 \%);

- выстраивание единой региональной системы профессионального развития педагогических работников и управленческих кадров образовательных организаций $(47,5 \%)$;

- разработка различных форм поддержки и сопровождения педагогических работников и управленческих кадров образовательных организаций и других организаций педагогической сферы $(47,5 \%)$;

- тьюторское сопровождение индивидуальных образовательных маршрутов педагогических кадров, построенных на основе диагностики профессиональных дефицитов $(32,5 \%)$;

\footnotetext{
18 Для участия в опросе была спроектирована стратифицированная выборка; в опросе вузов были представлены 41 образовательная организация высшего

образования. Это составило 17 \% от генеральной совокупности вузов, осуществляющих подготовку педагогических кадров. 
- создание единой системы выявления, обобщения, продвижения и внедрения подтвердивших эффективность педагогических и управленческих практик $(32,5 \%)$;

- создание научно-методического центра непрерывного педагогического образования педагогических кадров (32,5\%).

Таким образом, в большинстве образовательных организаций в качестве элементов непрерывного образования называются:

- создание условий для вовлечения педагогических работников в исследовательскую деятельность;

- развитие сетевого взаимодействия между субъектами научно-методической деятельности для создания единой информационно-методической среды, способствующей профессиональному росту педагогических работников и управленческих кадров;

- выстраивание единой региональной системы профессионального развития педагогических работников и управленческих кадров образовательных организаций.

Модель «Формирование педагогических региональных кластеров» (представлена в паспорте ФГБОУ ВО «Уральский государственный педагогический университет» (Уральский федеральный округ).

Педагогический кластер - это совокупность взаимосвязанных образовательных организаций общего и профессионального образования, объединенных партнерскими отношениями на основе общих целей и сбалансированного представления интересов участников кластерного взаимодействия. Педагогический кластер сегодня рассматривается как важная система взаимодействия нового типа,

\footnotetext{
${ }^{19}$ В опросе, проведенном в рамках НИР, приняло участие 58 исполнительных органов государственной
}

основывающаяся на добровольном сотрудничестве, развитых коммуникациях и социальном партнерстве [3].

Следует заметить, что движение по созданию региональных педагогических кластеров начинает активно развиваться. Из опроса исполнительных органов государственной власти субъектов Р $\Phi^{19}$ в сфере управления образованием следует, что в $21 \%$ регионов, участников опроса, уже действуют педагогические кластеры. Они созданы в Архангельской, Вологодской, Волгоградской, Кемеровской, Московской, Нижегородской, Ростовской, Саратовской, Смоленской, Свердловской, Тюменской областях и Хабаровском крае.

По мнению участников экспертного опроса $^{20}$, в основу работы педагогического кластера должен быть заложен анализ качественного состава педагогических кадров в субъекте РФ, причин дефицита педагогических кадров, уровня осознанности педагогическими работниками педагогических смыслов и целевых ориентиров региональных образовательных систем.

Ведущими факторами в работе педкластера должны выступать уровень взаимодействия и взаимодополняемости в деятельности субъектов, осуществляющих педагогическое образование и подготовку педагогических кадров, степень развития научно-методического сетевого взаимодействия между ними, позволяющий интегрировать передовой опыт педагогической деятельности и консолидировать имеющиеся в регионе прежде всего инфраструктурные и иные ресурсы.

Центральными направления деятельности целесообразно рассматривать:

власти субъектов РФ в сфере управления образованием.

${ }^{20}$ Было опрошено 49 экспертов. 
- формирование единого информационно-образовательного пространства субъектов педагогической деятельности;

- разработку механизмов преодоления профессионального выгорания педагогических работников различного уровня образования;

- разработку технологий развития творческого мышления обучающихся и педагогов;

- формирование системы изучения и транслирования инновационного опыта педагогической деятельности в преподавательской и воспитательной работе;

- ориентации образовательных программ на изучение культурного наследия, исторических традиций субъектов Российской Федерации и страны в целом, региональных особенностей развития и повышения мотивации обучающихся для включения в процессы социально-экономических преобразований в регионах и муниципальных образованиях;

- повышение статуса и престижа преподавательский деятельности.

Модель "Создание педагогических технопарков» (представлена в паспорте ФГБОУ ВО «Уральский государственный педагогический университет» (Уральский федеральный округ)).

Модель «Научно-методическое обеспечение подготовки педагогов с учетом исторического и культурного наследия регионов» (представлена в паспорте ФГБОУ ВО «Волгоградский государственный социально-педагогический университет» (Южный федеральный округ)).

Необходимо отметить, что перспективность данных моделей подтвердили эксперты

\footnotetext{
${ }^{21}$ В качестве экспертов было опрошено 50 человек из 20 регионов РФ, представляющих все 8 федеральных округов.
}

из органов исполнительной власти субъектов Российской Федерации - участники опроса в рамках исследования.

В рамках исследования в ходе экспертных интервью, проведенных во всех федеральных округах, были изучены экспертные мнения по определению показателей эффективности реализации моделей региональных систем подготовки педагогических кадров во взаимодействии федеральных и региональных участников образовательного процесса. Экспертами ${ }^{21}$ были предложены следующие показатели:

- процент выпускников, трудоустроившихся по направлению подготовки;

- длительность закрепления выпускников вузов на рабочих местах по специальности после первого трудоустройства;

- наличие и развитие научно-педагогических школ (направлений) в вузах/регионе;

- преемственность основных образовательных программ образовательных организаций среднего профессионального и высшего образования;

- партнерство между субъектами подготовки педагогических кадров и работодателями;

- профессионально-личностные достижения выпускников;

- включенность студенчества в социально-культурное пространство региона;

- ведение реестра лучших выпускников по УГСН по 44.00.00 «Образование и педагогические науки»;

- ведение реестра лучших педагогов региона;

- наличие утвержденной органами власти региона модели подготовки педагогических кадров, ориентированной на решение 
профессиональных дефицитов региона в сфере образования, отдыха и оздоровления детей.

\section{Обсуждение, заключение}

Анализ моделей региональных систем подготовки педагогических кадров во взаимодействии федеральных и региональных участников образовательного процесса показывает различный уровень формализации и нормативной оформленности моделей, различную степень их научно-методической и теоретической проработанности, согласованности целевых установок и показателей результативности деятельности.

По итогам исследования был сформулирован ряд рекомендаций по повышению эффективности реализации региональных моделей подготовки педагогических кадров во взаимодействии федеральных и региональных участников образовательного процесса:

- рекомендовать апробированный в ходе исследования паспорт региональной модели подготовки педагогических кадров как типовой, утвердить его нормативным актом Министерства просвещения Российской Федерации;

- рекомендовать проведение окружных круглых столов по обсуждению вопросов подготовки педагогических кадров, обмена опытом в этой сфере в качестве систематических мероприятий;

- совершенствовать формы взаимодействия педагогических университетов со всеми заинтересованными в педагогических кадрах ведомствами, учреждениями, организациями, в том числе работодателями;

- встраивать в систему непрерывного педагогического образования субъектов Российской Федерации такие современные организации дополнительного образования, как технопарки, кванториумы, а также всероссийские детские центры «Орленок», «Смена», «Океан», международный детский центр «Артек», профильные педагогические вузы, подведомственные Министерству просвещения РФ как научно-методические ресурсные центры развития непрерывного педагогического образования;

- развивать систему педагогических классов как инструмент предпрофессиональной подготовки и профессиональной мотивации будущих учителей, рассматривать педагогические классы в структуре совокупности образовательных организаций, обеспечивающих непрерывность подготовки педагогических кадров;

- организовывать взаимодействие образовательных организаций высшего образования независимо от их ведомственной подчиненности как на федеральном и окружном уровнях, так и на уровне субъекта Российской Федерации, в том числе в рамках профессиональных ассоциаций, например Ассоциации педагогического образования;

- активнее использовать в подготовке педагогических кадров в вузах возможности дисциплины «Основы вожатской деятельности», летней педагогической вожатской практики для формирования устойчивой профессиональной мотивации студентов к педагогической деятельности;

- организациям, осуществляющим повышение квалификации педагогических работников, при разработке программ ориентироваться на профессиональные дефициты педагогических работников в современном мире, в том числе используя возможности технопарков и кванториумов и т. д.

Несомненно, позитивным является то, что в моделях нашли отражение специфика региональных педагогических систем, ориентация на применение инновационных техноло- 
гий взаимодействия участников регионального образовательного пространства, ориентация на эффективную коммуникацию организаций, осуществляющих подготовку педагоги- ческих кадров и работодателей при интегрирующей функции органов государственной власти субъектов Российской Федерации, установка на повышение качества подготовки педагогических кадров.

\section{СПИСОК ЛИТЕРАТУРЫ}

1. Елисеева А. М. Готовность моделей вузовского управления к реформе высшей школы // Социологические исследования. - 2009. - № 12. - С. 131-134. URL: https://www.elibrary.ru/item.asp?id=13582302

2. Осипов А. М., Матвеева Н. А., Бояджиева П. А., Воронцов Я. А. Российское образование в бумажной пучине: опыт социологического анализа // Социологические исследования. 2020. - № 3. - C. 60-70. DOI: https://doi.org/10.31857/S013216250008798-0 URL: https://www.elibrary.ru/item.asp?id=42517808

3. Давыдова Н. Н., Игошев Б. М., Фоменко С. Л. Развитие педагогического (образовательного) кластера в региональном образовательном пространстве // Педагогическое образование в России. - 2015. - № 11. - C. 12-18. URL: https://www.elibrary.ru/item.asp?id=25295737

4. Caniëls M. C. J., van den Bosch H. The role of Higher Education Institutions in building regional innovation systems // Papers in Regional Science. - 2011. - Vol. 90 (2). - P. 271-286. DOI: https://doi.org/10.1111/j.1435-5957.2010.00344.x

5. Mrcog J. M. Developing a regional education programme to support structured training // The Obstetrician \& Gynaecologist. - 2003. $\quad$ - Vol. 5 (3). $\quad$ - P. 160-164. DOI: https://doi.org/10.1576/toag.5.3.160

6. Chiang R. J., Meagher W., Slade S. How the Whole School, Whole Community, Whole Child Model Works: Creating Greater Alignment, Integration, and Collaboration Between Health and Education // Journal of School Health. - 2015. - Vol. 85 (11). - P. 775-784. DOI: https://doi.org/10.1111/josh.12308

7. Gamsu S., Donnelly M. Social Network Analysis Methods and the Geography of Education: Regional Divides and Elite Circuits in the School to University Transition in the UK // Tijdschrift voor economische en sociale geografie. - 2021. - Vol. 112 (4). - P. 370-386. DOI: https://doi.org/10.1111/tesg.12413

8. Clasen D. R., Hanson M. Double mentoring: A process for facilitating mentorships for gifted students // Roeper Review. - 1987. - Vol. 10 (2). - P. 107-110. DOI: https://doi.org/10.1080/02783198709553096

9. Besnoy K. D., McDaniel S. C. Going up in dreams and esteem: Cross-age mentoring to promote leadership skills in high school-age gifted students // Gifted Child Today. - 2016. - Vol. 39 (1). P. 18-30. DOI: https://doi.org/10.1177/1076217515613386

10. Donlan A. E., McDermott E. R., Zaff J. F. Building relationships between mentors and youth: Development of the TRICS model // Children and Youth Services Review. - 2017. - Vol. 79. P. 385-398. DOI: https://doi.org/10.1016/j.childyouth.2017.06.044

11. Грачева Л. Ю., Баграмян Э. Р., Цыганкова М. Н., Дугарова Т. Ц., Шевелева Н. Н. Модели и практики профессионального развития учителей в зарубежных системах образования // Образование и наука. - 2020. - Т. 22, № 6. - С. 176-200. DOI: https://doi.org/10.17853/1994-56392020-6-176-200 URL: https://www.elibrary.ru/item.asp?id=43795225 
12. Niemi H. Teacher professional development in Finland: Towards a more holistic approach // Psychology, Society and Education. - 2015. - Vol. 7 (3). - P. 278-294. DOI: https://doi.org/10.25115/psye.v7i3.519

13. Penfold P., van der Veen R. Investigating Learning Approaches of Confucian Heritage Culture Students and teachers' Perspectives in Hong Kong // Journal of Teaching in Travel \&Tourism. 2014. - Vol. 14 (1). - P. 69-86. DOI: https://doi.org/10.1080/15313220.2014.872903

14. Hargreaves E., Berry R., Lai Y. C., Leung P., Scott D., Stobart G. Teachers' experiences of autonomy in Continuing Professional Development: Teacher Learning Communities in London and Hong Kong // Teacher Development. - 2013. - Vol. 17(1). - P. 19-34. DOI: https://doi.org/10.1080/13664530.2012.748686

15. Гинецинский В. И. Единство философии образования, педагогики и методики ее преподавания // Ученые записки Санкт-Петербургского государственного института психологии и социальной работы. - 2005. - Т. 5. - С. 5-8. URL: https://www.elibrary.ru/item.asp?id=12893508

16. Землянская Е. Н. Моделирование как метод педагогического исследования // Преподаватель XXI век. - 2013. - № 3-1. - C. 35-43. URL: https://www.elibrary.ru/item.asp?id=20316556

17. Владимирова Т. Н., Шаламова Л. Ф., Лесконог Н. Ю. Роль высших учебных заведений в формировании кадрового потенциала организаций отдыха и оздоровления детей и молодежи: результаты мониторинга // Высшее образование сегодня. - 2020. - № 10. - C. 64-70. DOI: https://doi.org/10.25586/RNU.HET.20.10.P.64 URL: https://www.elibrary.ru/item.asp?id=44005237

18. Лесконог Н. Ю., Шаламова Л. Ф., Марусяк Д. М. Педагогическая практика студентов как основной компонент реализации модуля «Основы вожатской деятельности» // Вестник педагогических инноваций. - 2018. - № 4. - C. 47-53. URL: https://elibrary.ru/item.asp?id=36885067

19. Владимирова Т. Н., Лесконог Н. Ю., Марусяк Д. М. Представленность подготовки вожатских кадров в педагогических вузах: результаты исследования // Преподаватель XXI век. 2021. - № 4-1. - C. 37-44. DOI: https://doi.org/10.31862/2073-9613-2021-4-37-44 URL: https://elibrary.ru/item.asp?id=47573354

Поступила: 21 Ноября 2021 Принята: 10 января 2022 Опубликована: 28 февраля 2022

\section{Заявленный вклад авторов:}

Шаламова Любовь Федоровна: разработка инструментария и программы исследования, участие в разработке паспорта региональной модели, участие в проведение исследования региональных моделей, обобщение и анализ материалов исследования, обзор литературы по теме статьи, написание статьи, редактирование материалов.

Марусяк Дарья Михайловна: обработка данных о региональных моделях, подготовка информации для написания статьи.

Владимирова Татьяна Николаевна: редактирование материалов статьи, общее руководство проведением исследования. 
Лесконог Наталья Юрьевна: разработка инструментария, организация проведения исследований, разработка паспорта региональной модели, написание статьи, редактирование текста статьи, взаимодействие с редакцией.

\section{Информация о конфликте интересов:}

Авторы заявляют об отсутствии конфликта интересов.

\section{Информация об авторах}

\section{Шаламова Любовь Федоровна}

кандидат социологических наук, доцент ВАК, доцент, кафедра «Государственное управление и социальные технологии», Института Инженерной экономики и гуманитарные науки, Московский авиационный институт (национальный исследовательский университет (МАИ), Волоколамское шоссе, д. 4, 125993, Москва, Россия.

Аналитик Федерального координационного центра по подготовке и сопровождению вожатских кадров, Московский педагогический государственный университет (МПГУ), ул. Малая Пироговская, д. 1, стр. 1, 119991, Москва, Россия. ORCID ID: https://orcid.org/0000-0001-7166-1760

E-mail: 1fsh57@mail.ru

\section{Марусяк Дарья Михайловна}

заместитель директора,

Федеральный координационный центр по подготовке и сопровождению вожатских кадров, ассистент, кафедра медиаобразования, Институт журналистики, коммуникаций и медиаобразования,

Московский педагогический государственный университет (МПГУ), ул. Малая Пироговская, д. 1, стр. 1, 119991, Москва, Россия.

ORCID ID: https://orcid.org/0000-0002-1033-3613

E-mail: dm.marusyak@mpgu.su

\section{Владимирова Татьяна Николаевна}

доктор педагогических наук, директор Института журналистики, коммуникаций и медиаобразования, проректор по связям с общественностью,

Московский педагогический государственный университет (МПГУ),

ул. Малая Пироговская, д. 1, стр. 1, 119991, Москва, Россия.

ORCID ID: https://orcid.org/0000-0001-9368-404X

E-mail: tn.vladimirova@mpgu.su 


\section{Лесконог Наталья Юрьевна}

кандидат педагогических наук, доцент, кафедра медиаобразования, Институт журналистики, коммуникаций и медиаобразования, директор Федерального координационного центра по подготовке и сопровождению вожатских кадров,

Московский педагогический государственный университет (МПГУ),

ул. Малая Пироговская, д. 1, стр. 1, 119991, Москва, Россия.

ORCID ID: https://orcid.org/0000-0001-5187-3037

E-mail: leskonog@mail.ru 


\title{
Regional model of teacher education as a research problem
}

\author{
Lubov F. Shalamova ${ }^{1,2}$, Darya M. Marusyak ${ }^{1}$, Tatiana N. Vladimirova ${ }^{1}$, Natalia Y. Leskonog $\square^{1}$ \\ ${ }^{1}$ Moscow Pedagogical State University (MPSU), Moscow, Russian Federation \\ ${ }^{2}$ Moscow Aviation Institute (National Research University (MAI), Moscow, Russian Federation
}

\begin{abstract}
Introduction. The authors investigate the problem of improving the quality of education with the main focus on initial teacher education. The purpose of this study is to identify the characteristic features of modern regional models of teacher education using the system modeling method.

Materials and Methods. In order to investigate regional models of teacher education, the following methods were employed: a focus-group research technique, expert surveys and opinion polls. The sample included highly qualified practitioners and leaders of higher educational institutions, vocational educational settings and secondary educational institutions as well as recreation and health improvement organizations for children.

The comparative analysis of the regional models was conducted using the profile of the regional model of teacher education developed by the authors.

Results. The article presents an analytical review of modern regional teacher education models, carried out as a part of the research investigation conducted by Moscow Pedagogical State University on behalf of the Ministry of Education of the Russian Federation "Comparative analysis of models of regional teacher education systems with the main focus on 8 federal districts of the Russian Federation and the specifics of interaction between federal and regional stakeholders within the educational policy."

The study has revealed, described and analyzed eight most common models of teacher education in regional education systems in each of the federal districts. The authors emphasize that it is significant to document unique practices of teacher education and present them to the professional community and
\end{abstract}

\section{Acknowledgments}

The study was financially supported by the Ministry of Education of the Russian Federation by a state assignment. Project No. 073-00042-21-02 ("Scientific analysis of the application of a unified methodology of social and psychological testing of students, aimed at early detection of non-medical consumption of narcotic drugs and psychotropic substances, and its refinement").

\section{For citation}

Shalamova L. F., Marusyak D. M., Vladimirova T. N., Leskonog N. Y. Regional model of teacher education as a research problem. Science for Education Today, 2022, vol. 12 (1), pp. 99-125. DOI: http://dx.doi.org/10.15293/26586762.2201 .05

Corresponding Author: Natalia Y. Leskonog, leskonog@mail.ru

(C) Lubov F. Shalamova, Darya M. Marusyak, Tatiana N. Vladimirova, Natalia Y. Leskonog, 2022 


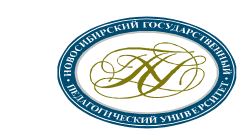

Science for Education Today

2022, vol. 12, issue 1 http://en.sciforedu.ru/

ISSN 2658-6762

experts using a unified model profile. Moreover, they highlight the need for expanding networking, involving both regional and federal stakeholders in the field of education.

Conclusions. The research findings can be used by state authorities of the subjects of the Russian Federation, federal districts of the Russian Federation, and educational institutions of higher education to improve the efficiency of the regional teacher education models, integrating them into a unified environment of teacher education in Russia.

The profile of the regional model of teacher education evaluated during the research investigation can be offered as a standard one.

Keywords

Regional model of teacher education; Profile of the model; Career programmes in teaching and education for high school students; Mentoring; Educational cluster; Teaching staff; Technopark; Continuing professional development in the field of education.

\section{REFERENCES}

1. Eliseeva A. M. Readiness of university management models for higher school reform. Sociological Research, 2009, no. 12, pp. 131-134. (In Russian) URL: https://www.elibrary.ru/item.asp?id=13582302

2. Osipov A. M., Matveeva N. A., Boyadzhieva P. A., Voroncov Y. A. Russian education in paper abyss: A sociological view. Sociological Research, 2020, no. 3, pp. 60-70. (In Russian) DOI: https://doi.org/10.31857/S013216250008798-0

URL: https://www.elibrary.ru/item.asp?id=42517808

3. Davydova N. N., Igoshev B. M., Fomenko S. L. Development of the pedagogical (educational) cluster in regional educational environment. Pedagogical Education in Russia, 2015, no. 11, pp. 12-18. (In Russian) URL: https://www.elibrary.ru/item.asp?id=25295737

4. Caniëls M. C. J., van den Bosch H. The role of higher education institutions in building regional innovation systems. Papers in Regional Science, 2011, vol., 90 (2), pp. 271-286. DOI: https://doi.org/10.1111/j.1435-5957.2010.00344.x

5. Mrcog J. M. Developing a regional education programme to support structured training. The Obstetrician \& Gynaecologist, 2003, vol. 5 (3), pp. 160-164. DOI: https://doi.org/10.1576/toag.5.3.160

6. Chiang R. J., Meagher W., Slade S. How the whole school, whole community, whole child model works: Creating greater alignment, integration, and collaboration between health and education. Journal of School Health, 2015, vol. 85 (11), pp. 775-784. DOI: https://doi.org/10.1111/josh.12308

7. Gamsu S., Donnelly M. Social network analysis methods and the geography of education: Regional divides and elite circuits in the school to university transition in the UK. Tijdschrift Voor Economische en Sociale Geografie, 2021, vol. 112 (4), pp. 370-386. DOI: https://doi.org/10.1111/tesg.12413

8. Clasen D. R., Hanson M. Double mentoring: A process for facilitating mentorships for gifted students. Roeper Review, 1987, vol. 10 (2), pp. 107-110. DOI: https://doi.org/10.1080/02783198709553096

9. Besnoy K. D., McDaniel S. C. Going up in dreams and esteem: Cross-age mentoring to promote leadership skills in high school-age gifted students. Gifted Child Today, 2016, vol. 39 (1), pp. 18 30. DOI: https://doi.org/10.1177/1076217515613386 
10. Donlan A. E., McDermott E. R., Zaff J. F. Building relationships between mentors and youth: Development of the TRICS model. Children and Youth Services Review, 2017, vol. 79, pp. 385398. DOI: https://doi.org/10.1016/j.childyouth.2017.06.044

11. Gracheva L. Y., Bagramyan E. R., Cygankova M. N., Dugarova T. C., Sheveleva N. N. Teacher professional development models and practices in foreign educational systems. The Education and Science Journal, 2020, vol. 22 (6), pp. 176-200. (In Russian) DOI: https://doi.org/10.17853/19945639-2020-6-176-200 URL: https://www.elibrary.ru/item.asp?id=43795225

12. Niemi H. Teacher professional development in Finland: Towards a more holistic approach. Psychology, Society and Education, 2015, vol. 7 (3), pp. 278-294. DOI: https://doi.org/10.25115/psye.v7i3.519

13. Penfold P., van der Veen R. Investigating learning approaches of Confucian heritage culture students and teachers' perspectives in Hong Kong. Journal of Teaching in Travel \&Tourism, 2014, vol. 14 (1), pp. 69-86. DOI: https://doi.org/10.1080/15313220.2014.872903

14. Hargreaves E., Berry R., Lai Y. C., Leung P., Scott D., Stobart G. Teachers' experiences of autonomy in continuing professional development: Teacher learning communities in London and Hong Kong. Teacher Development, 2013, vol. 17 (1), pp. 19-34. DOI: https://doi.org/10.1080/13664530.2012.748686

15. Ginetsinsky V. I. Unity of philosophy of education, pedagogy and methods of its teaching. Scientific notes of the St. Petersburg State Institute of Psychology and Social Work, 2005, vol. 5, pp. 5-8. (In Russian) URL: https://www.elibrary.ru/item.asp?id=12893508

16. Zemlyanskaya E. N. Modeling as a method of pedagogical research. Teacher of the XXI century, 2013, no. 3-1, pp. 35-43. (In Russian) URL: https://www.elibrary.ru/item.asp?id=20316556

17. Vladimirova T. N., Shalamova L. F., Leskonog N.Y. the role of higher education institutions in the formation of hr potential of recreation organizations for children and youth: monitoring results. Higher Education Today, 2020, no. 10, pp. 64-70. (In Russian) DOI: https://doi.org/10.25586/RNU.HET.20.10.P.64 URL: https://www.elibrary.ru/item.asp?id=44005237

18. Leskonog N. Y., Shalamova L. F., Marusyak D. M. Pedagogical practice of students as the main component of the module "basics of leadership activity". Bulletin of Pedagogical Innovations, 2018, no. 4, pp. 47-53. (In Russian) URL: https://elibrary.ru/item.asp?id=36885067

19. Vladimirova T. N., Leskonog N. Yu., Marusyak D. M. Representation of personnel training in pedagogical universities: research results. Teacher XXI Century, 2021, no. 4-1, pp. 37-44. (In Russian) DOI: https://doi.org/10.31862/2073-9613-2021-4-37-44 URL: https://elibrary.ru/item.asp?id=47573354

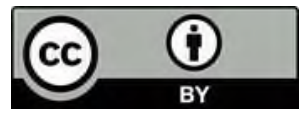

This is an open access article distributed under the Creative Commons Attribution License which permits unrestricted use, distribution, and reproduction in any medium, provided the original work is properly cited. (CC BY 4.0). 


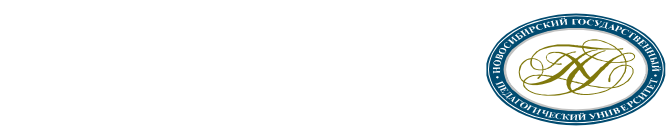

Science for Education Today

2022, vol. 12, issue 1 http://en.sciforedu.ru/

ISSN 2658-6762

\section{The authors' stated contribution:}

Lubov Fyodorovna Shalamova,

Contribution of the co-author: development of research tools and programs, participation in the development of a passport of a regional model, participation in the study of regional models, generalization and analysis of research materials, literature review on the topic of the article, writing a summary text of the article, editing materials

Darya Mikhailovna Marusyak,

Contribution of the co-author: processing of data on regional models, preparation of information for writing an article.

Tatiana Nikolaevna Vladimirova,

Contribution of the co-author: editing of the materials of the article, management of the research.

Natalia Yurievna Leskonog,

Contribution of the co-author: development of tools, organization of research, development of a passport of a regional model, writing an article, editing the text of an article, interaction with the editors

\section{Information about competitive interests:}

The authors claim that they do not have competitive interests.

\section{Information about the Authors}

\section{Lubov Fyodorovna Shalamova}

Candidate of Sociological Sciences, Associate Professor, Head,

Department of "Public administration and social technologies", Institute of

Engineering Economics and Humanities,

Moscow aviation Institute (national research University (MAI),

Volokolamsk highway, 4, 125993, Moscow, Russian Federation.

Analyst,

Federal Coordination Center for Training and support of Counselors,

Moscow Pedagogical State University (MPSU),

Malaya Pirogovskaya str., 1, p. 1, 119991, Moscow, Russian Federation.

ORCID ID: https://orcid.org/0000-0001-7166-1760

E-mail: 1fsh57@mail.ru

\section{Darya Mikhailovna Marusyak}

Deputy Director,

Federal Coordination Center for Training and support of Counselors,

Assistant,

Department of Media Education, Institute of Journalism, Communications and Media Education,

Moscow Pedagogical State University (MPSU),

Malaya Pirogovskaya str., 1, p. 1, 119991, Moscow, Russian Federation.

ORCID ID: https://orcid.org/0000-0002-1033-3613

E-mail:dm.marusyak@mpgu.su 


\section{Tatiana Nikolaevna Vladimirova}

Doctor of Pedagogical Sciences, Director, Institute of Journalism, Communications and Media Education,

Vice-Rector for Public Relations,

Moscow Pedagogical State University (MPSU),

Malaya Pirogovskaya str., 1, p. 1, 119991, Moscow, Russian Federation.

ORCID ID: https://orcid.org/0000-0001-9368-404X

E-mail: tn.vladimirova@mpgu.su

\section{Natalia Yurievna Leskonog}

Candidate of Pedagogical Sciences, Associate Professor,

Department of Media Education, Institute of Journalism, Communications and Media Education,

Director,

Federal Coordination Center for Training and support of Counselors,

Moscow Pedagogical State University (MPSU),

Malaya Pirogovskaya str., 1, p. 1, 119991, Moscow, Russian Federation.

ORCID ID: https://orcid.org/0000-0001-5187-3037

E-mail: leskonog@mail.ru (Corresponding Author) 


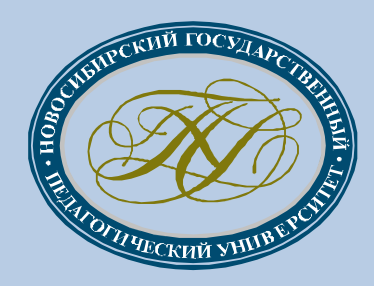

www.sciforedu.ru

\section{ФИЛОЛОГИЯ И КУЛЬТУРА \\ ДЛЯ ОБРАЗОВАНИЯ}

\section{PHILOLOGY AND CULTURAL \\ FOR EDUCATION}




\title{
Studying the practices of implementing a multilingual model of multicultural education in the Russian Federation
}

\author{
Raisa M. Iksanova ${ }^{1}$, Zarima R. Kireeva ${ }^{1}$, Eduard I. Sattarov ${ }^{1}$, Salavat T. Sagitov $\square \Omega^{1}$ \\ ${ }^{1}$ Bashkir State Pedagogical University named after M. Akmulla, Ufa, Russian Federation
}

\begin{abstract}
Introduction. The article discusses the practices of implementing a multilingual model of multicultural education in the Russian Federation. The Russian Federation is a multinational and linguistically diverse country. The official language of the country is Russian; 37 state languages are spoken in the republics of the Russian Federation; more than 15 languages have an official status. For a number of regions of the country, the model of multilingual learning is extremely relevant.

The purpose of the article is to study the practices of implementing a multilingual model of multicultural education in the territory of the Russian Federation and to conduct their comparative analysis.

Materials and Methods. Within the framework of the study, the analysis of legislative documents regulating the processes of multicultural and multilingual education in the Republic of North OssetiaAlania, Kabardino-Balkar Republic, Chechen Republic, Republic of Sakha (Yakutia), Republic of Tatarstan, Chuvash Republic, Republic of Bashkortostan (state programs, concepts, regulations, etc.) was carried out. Data gathering included round-table discussions and interviews with the representatives of academic and teaching communities of the regions; analyses of curricula, syllabi and teaching materials on language disciplines; lesson observations; questionnaires and language assessment of primary (4th grade) and secondary schoolchildren (8th grade) in foreign and native languages; analysis of academic performance and attainment (e.g. the results of the All-Russian Olympiad of schoolchildren in Russian and Foreign Languages, national assessment, state final certification, and final national examinations).

Results. The research team of Bashkir State Pedagogical University named after M. Akmulla, in accordance with the state task in the field of science of the Ministry of Education of the Russian Federation, has been implementing a research investigation 'Comparative analysis of the practices of
\end{abstract}

\section{Acknowledgments}

The study was financially supported by the Ministry of Education of the Russian Federation. Project No. 073-032021-015/2, Dated 07/21/2021 (within the framework of the state task for the implementation of research work "Comparative analysis of the practices of implementing a multilingual model of multicultural education").

\section{For citation}

Iksanova R. M., Kireeva Z. R., Sattarov E. I., Sagitov S. T. Studying the practices of implementing a multilingual model of multicultural education in the Russian Federation. Science for Education Today, 2022, vol. 12 (1), pp. 127-149. DOI: http://dx.doi.org/10.15293/2658-6762.2201.06

曰@ Corresponding Author: Salavat T. Sagitov, salavatst@list.ru

(C) Raisa M. Iksanova, Zarima R. Kireeva, Eduard I. Sattarov, Salavat T. Sagitov, 2022 
implementing a multilingual model of multicultural education (with the main focus on the Republics of Bashkortostan, Tatarstan, North Ossetia-Alania, Sakha (Yakutia), etc.)' since 2021.

The authors have determined the main types of models of multilingual education implemented in the studied regions. In particular, the models presented in the Republic of North Ossetia-Alania, the Republic of Tatarstan and the Republic of Sakha (Yakutia) are reported to be the most developed as they have been implemented for several years. The findings in this study contribute to a greater understanding of the specifics of multilingual education in Russia and the study makes a theoretical contribution to multilingual education in general.

Conclusions. The article concludes that currently there is no a single coordinated model for multilingual education in Russian schools. The development of a multilingual model of multicultural education is primarily aimed at preserving and further developing the native languages in the subjects of the Russian Federation, remaining one of the most important tasks not only in terms of solving narrow ethno-cultural problems, but also in the context of preserving the natural multicultural basis of the multinational Russian state.

\section{Keywords}

Multilingual education; Multilingual model; Practice of implementing a multilingual model; Multicultural environment; Comparative analysis of practices of implementing a multilingual model; Education system; Native language.

\section{Introduction}

One of the most important and integral elements of culture is language. There is not a single human community, not a single culture that would exist without a language [1]. At the same time, language, by its very nature, cannot exist without culture. Language is currently the main means of preserving, developing and transmitting cultural values, both within one society and between different social groups and communities in each specific period of time, as well as in historical perspective and retrospective, and the importance of language as one of the elements of culture is difficult to underestimate both in the development of any social community and in the formation of Russian statehood and national selfidentity [2]. A decrease in the presence of language in various spheres of human activity can lead not only to a reduction in its use, but also to a further rejection of its use [3]. Given that language is one of the most important elements of an individual's self-determination on a national basis, it can be argued that the disappearance of a language entails the disappearance of an ethnic group as such. That is why the issues of language preservation today, in the period of globalization and intensive digitalization, acquire a special connotation, posing questions of determining the vector of further development to different social communities, especially in such a multinational country as the Russian Federation.

According to the classification adopted by $\mathrm{UNESCO}^{1}$, all languages, depending on a number of factors (the absolute number of native speakers, the transfer of the language to the next generation, the scope of language use, administrative use of the language, the degree of its documentation, etc.) are divided into six categories:

$$
\begin{aligned}
& \text { - safe; } \\
& \text { - vulnerable; }
\end{aligned}
$$

\footnotetext{
${ }^{1}$ The UNESCO Atlas of the world's languages in danger: context and process / University of Cambridge Museum of Archaeology and Anthropology, 2012.
} 
- definitely endangered;

- severely endangered;

- critically endangered;

- extinct.

UNESCO has developed a comprehensive methodology to assess the state of linguistic diversity in the world as part of the Organization's commitment and contribution to the promotion of linguistic diversity and multilingualism. Thanks to the contribution of UNESCO member States, researchers, experts and other stakeholders to the Global Survey of Languages launched in 2018 by the UNESCO Institute of Statistics, the development of the World Atlas of Languages is entering its final phase and is to be presented at the $41 \mathrm{st}$ session of the UNESCO General Conference in November $2021^{2}$.

In total, the UNESCO Atlas for 2020, out of more than 6 thousand languages existing in the world, recognizes 2.5 thousand as endangered ${ }^{3}$. Also, according to the expert assessment of the Institute of Linguistics of the Russian Academy of Sciences, there are 151 languages in Russia, of which 18 are on the verge of extinction ${ }^{4}$. At the same time, 14 languages disappeared on the territory of the Russian Federation in the XXXXI centuries, half of which did so in the postSoviet period. Of the remaining languages of Russia, according to the Atlas of Endangered Languages of the World, published by UNESCO in 2020, 136 languages of the peoples and nationalities of Russia are in varying degrees under threat: the state of 20 languages (including Bashkir, Kabardino-Circassian, Chechen, Yakut) is of concern; 49 (including Chuvash, Udmurt, Kalmyk) are endangered; 20 (including Karelian, Chukchi) are in serious danger, 22 languages are in critical condition, and 20 languages have already been recognized as extinct.

Currently, the main feature is that the changes that have occurred in the country over the past 25-30 years have affected not only the country's economy or its political system - the country's population, value orientations and many other things have changed. For the most part, the changes affected young people who have their own attitudes, but have no physical connection with the Soviet period and are not focused on the values inherent in the youth of that time.

To become a full-fledged subject of the social structure, an individual must undergo socialization, master not only knowledge, skills and abilities to perform appropriate professional and other role functions, but also integrate into the system of socio-cultural values, moral norms and ideals, which in turn are in the process of constant change.

It is worth nothing that there was no scientific literature on the comparative analysis of implementation practices and the study of polylingual models of multicultural education in the Russian Federation.

However, in recent years, interest in the study of multilingual learning through the prism of various aspects has been increasing. However, in recent years, interest in the study of polylingual

${ }^{3}$ UNESCO Atlas of the World's Languages in Danger. URL: http://www.unesco.org/new/en/culture/themes/endangered-languages/atlas-of-languages-in-danger/ Accessed: $30^{\text {th }}$ November 2021.

4 Federal Agency for Nationalities. URL: https://fadn.gov.ru/system/attachments/attaches/000/029/833/original/aakibrik_ashl_dialforum2018.ppt?1542391737 Accessed: 22nd April 2019. 
(multilingual) education has been increasing [4; 5; 6]. This is due to a number of reasons.

Thus, the authors indicate that one of the main reasons is the training of personnel for the implementation of multilingual education, insufficient training of teachers to work effectively with multilingual students [7].

"The intensification of global mobility has increased interest in ethnolinguistic diversity and multilingualism in education and society. Interdisciplinary research approaches to multilingual education combine modern interdisciplinary perspectives in the field of multilingual and a second language education for the study of research and teaching of languages in particular countries" [8].

Also, a number of authors point to an important aspect - the participation of parents in the language development of their children [9].

The problems of multilingual education are also studied in the context of social justice ${ }^{5}$, and the practice of multilingual literacy is considered as a springboard for the development of learning opportunities and identity formation [10-12].

The problem of polylingual education is relevant for a number of countries, for example, a large-scale survey of 155 schools was conducted in Hong Kong. In-depth case studies were conducted in 3 selected schools, revealing the views on trilingual education of all stakeholders: school principals, group chairmen, subject teachers, students and parents. The research results indicate that the implementation of trilingual education varies significantly from school to school, as well as the effectiveness of the models of trilingual education used $[13 ; 14]$.

The features of polylingual learning are studied in the field of preschool education from a socio-linguistic point of view. The main attention is paid to preschool polylingual education, modern prospects of early polylingual education are investigated in the light of the threefold theoretical basis of interaction between preschool institutions, teachers and parents. For example, the authors propose the following theoretical concept which includes: the ecology of language learning, educational partnership in the interests of bilingualism, the concept of participation in early language development and education, a context conducive to language, and strategies promoting language development. Preschool bilingual education is considered as embedded in specific socio-cultural contexts, on the one hand, and its universal features are highlighted, on the other [15].

Polylingual education considers the possibility of preserving minority languages, the history of society, culture and customs [16].

The formation of motivation and identity of students in the process of learning and using several languages is considered as one of the problems of polylingual education. Based on the latest theoretical developments concerning the motivation and identity of students in researches related to the study of languages, scientists reveal the motivations of students that underlie their decisions about learning several languages. Through empirical research, the authors propose conceptual interpretations of emerging concepts, such as the dual motivation system, motivation dynamics, episodes of motivational transformation and hierarchies of identities $[17 ; 18]$.

Both Sweden and Finland have education systems that promote equality and equity. However, the social and political changes associated with increased immigration have

\footnotetext{
${ }^{5}$ Conteh J. Researching education for social justice in multilingual settings: ethnographic principles in qualitative research, 2017. $280 \mathrm{p}$.
} 
created new challenges in efforts to support linguistic diversity. The authors of the article study how multilingualism is represented in national compulsory school curricula in two contexts, using the framework of language orientation: language as a problem, a right or a resource. The analysis reveals differences. In Finland, there is a clear discussion about multilingual education with the aim of integrating multilingual aspects into the entire curriculum. However, in Sweden, the discourse is less explicit; and multilingualism as a concept is limited to minority language learners. The consideration of language orientations in two curricula makes it possible to understand the spaces for multilingual education, which are key to the capabilities of teachers to promote both linguistic diversity and social justice in the schools of modern global societies $[19 ; 20]$.

Professor Marianne Visser studies linguistic diversity in Africa, considering it an advantage rather than a complicating factor. "Multilingualism is undoubtedly an advantage. With that said, multilingual education is a really complex undertaking. In particular, the implementation of appropriate educational opportunities is a difficult task. In this regard, the goal is to emphasize the need for systematic cost management of multilingual education and to present the idea of cost optimization as an additional way to improve the practice of multilingual education" [21].

These circumstances, conditioned by the global trend towards integration in all spheres of life, as well as the diversity and multiculturalism of the Russian society, determine great increase of the role and relevance of the realization of the polylingual education concept. Before proceeding to further analysis, we note that in our research by polylingual education we mean a system of education and upbringing that promotes the general cultural and linguistic development of students, which implies a simultaneous use of the Russian, native and foreign languages in the educational process, including extracurricular time. It should also be noted that within the framework of our research, we adhere to the point of view that the terms "polylingual education" and "a polylingual model of multicultural education" are mutually applicable, since all the regions under consideration are multicultural, and the formation of language competence proceeds not only in terms of teaching a particular language, but also through the integration of interdisciplinary knowledge: culture, history, psychology of peoples, etc., covering extracurricular time. By the way, this is what, in our opinion, distinguishes polylingual education from bilingual or multilingual education: the essence of the polylingual education system is that, along with the native language, both Russian and a foreign one are used both as a means of teaching and as a means of multicultural education. Whereas in bilingual or multilingual schools, a language is only the subject of study [22-24].

We would like to note that the issues of polylingual education are relevant for all the regions and territorial communities of our country: republics, territories and regions; for megacities and large cities, for small towns and rural settlements, etc. At the same time, the formation of educational policy does not depend on the circumstances under which the polyethnicity of the population has developed. So, in some territories the multinational population was formed in the XX century (for example, Moscow and the Tyumen region) as a result of migration processes caused by economic aspects of development, whereas in others - its formation took place over a long period of time and today is interpreted as "historically formed" (for example, national republics). At the same time, the 
organization of polylingual education in each region of the country has its own peculiarities, depending on a number of reasons.

In particular, the defining aspect is the national composition of the federal subject: while only two state languages (Russian and Tatar) officially function in the Republic of Tatarstan, in Dagestan, with its ethnic diversity, according to Article 11 of the Constitution of the Republic, the state languages are Russian and the languages of the peoples of Dagestan, among which Avar, Agul, Azerbaijani, Darginsky, Kumyk, Lak, Lezginsky, Nogai, Rutul, Tabasaran, Tat, Tsakhur and Chechen languages have their written form and bare an official status. In addition to the absolute number of nationalities living in the regions, their percentage ratio also matters: while being the third in number in the population of the Kabardino-Balkarian Republic, the Balkars make up slightly less than $10 \%$ of the population of the region, the Tatars, who are also the third largest in the Chuvash Republic make up a little more than $2.8 \%$. The number of representatives of the Russian nationality is also different in the regions of the country: while in Bashkortostan the number of Russians is $40 \%$ (this is the 1 st place in the region among ethnic groups), in the Chechen Republic it is $2 \%$ (the 2 nd place in the region). Of course, the model of polylingual education is also significantly influenced by the territory of the region: compare, for example, huge Yakutia (more than 3 million square kilometers) exceeding Argentina in its territory - the eighth state in the world by area, and North OssetiaAlania, which occupies the 80th place in the Russian Federation by area (7987 square kilometers). At the same time, in the Republic

\footnotetext{
${ }^{6}$ Sagitov S. T. Socio-professional status as a criterion for the classification of social actors. Social consequences of the pandemic: myths and reality. Aitov readings: collec-

of Sakha, the population density is 0.32 people/sq.km, whereas in the Republic of North Ossetia-Alania - 86.78 people/sq. km.

Undoubtedly, the religious component of the region, as well as the belonging of the language to a particular family or group of languages, have a great influence on the development of languages. For example, the spread of Islam led to the inclusion of many borrowings from Arabic into the lexical composition of the languages of Muslim peoples and at the same time caused the consolidation of these languages as the main means of communication between their native speakers.

We can name a number of factors that affect the education system of a particular region of Russia as a whole: these are the infrastructure of social institutions of education and science, culture and religion, the level of urbanization and development of the means of production of the region, etc. In addition, both education and culture, as social institutions, have their own laws of self-development, depending, among other things, on a certain historical situation, and on the development level of the society as a whole, as well as on the level of management culture ${ }^{6}$. Naturally, all this leaves an imprint on the organization of the system of polylingual education [25].

The article discusses the practices of implementing a multilingual model of multicultural education in the Russian Federation. The Russian Federation is a multinational and linguistically diverse country. The official language of the country is Russian; 37 state languages are spoken in the republics of the Russian Federation; more than 15 languages have an official status. For a number of regions of the

tion of materials of the international scientific and practical conference. Ufa, 2021, pp. 22-27. (In Russian) URL: https://elibrary.ru/item.asp?id=45600865\& 
country, the model of multilingual learning is extremely relevant.

The purpose of the article is to study the practices of implementing a multilingual model of multicultural education in the territory of the Russian Federation and to conduct their comparative analysis.

\section{Methods}

In order to study the practices of implementing a polylingual model of multicultural education on the territory of the Russian Federation, to conduct their comparative analysis and develop methodological recommendations for the organization of multicultural education, in 2021, a team of researchers of Bashkir State Pedagogical University named after M. Akmulla, under the guidance of Candidate of Sociological Sciences S. T. Sagitov, started the research work "Comparative analysis of the practices of implementing a polylingual model of multicultural education (on the example of the Republics of Bashkortostan, Tatarstan, North Ossetia-Alania, Sakha (Yakutia), etc.)" in accordance with the state task in the field of science of the Ministry of Education of the Russian Federation.

The object of the study is the polylingual models of multicultural education implemented in secondary educational institutions of seven regions of the Russian Federation: the Republic of Bashkortostan, the Kabardino-Balkar Republic, the Republic of Sakha (Yakutia), the Republic of North Ossetia-Alania, the Republic of Tatarstan, the Chechen Republic, the Chuvash Republic.
The study involves several stages, planned for 2021-2023.

As is known, when studying social phenomena, sociologists tend to choose a research strategy that contributes to a more complete disclosure of the social nature of the phenomenon being studied. In this case, we mean an integrative research strategy that combines qualitative and quantitative research methods. Using only one strategy can lead to "one-sidedness" of the information received, since “... any methodological point of view is partial, incomplete. The polyphony of representations is necessary...."7.

To obtain information about the problem under study, a quantitative methodology of sociological research was chosen.

As the main method of data collection, selfcompletion questionnaires at the place of study were used. The method of continuous questioning of the 4th and 8th grade students in schools, where the model of polylingual learning is implemented, was used.

\section{Results}

Preliminary results of a survey of students of multilingual schools showed the importance of learning their native language. Among the main reasons were indicated: to speak freely with representatives of their ethnic group (more than a third of respondents), the language is an integral part of the history and culture of the ethnic group (less than $30 \%$ ) and to preserve their language $(14.0 \%)$. The full list of responses is given in the table.

\footnotetext{
7 Yarskaya-Smirnova E. R. Sociocultural analysis of atypicity. Saratov, 1997. p. 94. (In Russian) 
Distribution of answers to the question:

"Why do you think it is necessary to study your native (national language)?"

\begin{tabular}{|l|c|}
\hline \multicolumn{1}{|c|}{ Answer options (categorized) } & $\begin{array}{c}\text { Percentage of respondent (in } \\
\text { \%) }\end{array}$ \\
\hline To talk freely with representatives of their ethnic group & 31,9 \\
\hline Language is an integral part of the history and culture of the ethnos & 28,6 \\
\hline To preserve the ethnic group and its culture & 7,9 \\
\hline To preserve one's native language & 14,0 \\
\hline For general development / self-development & 6,1 \\
\hline All representatives of the ethnic group should know the language & 8,5 \\
\hline Other & 7,2 \\
\hline
\end{tabular}

Note: The students' answers to the open question "Why do you think it is necessary to study the native (national) language?" were grouped into several categories for ease of processing and use in data analysis.

During the survey, students were asked a number of open questions about their attitude to the need to learn their native language. As examples, we can cite some of the most striking statements of the students:

"It is very important to know your traditions and cultures in order to be a true representative of your nationality" (a student from the Republic of Sakha (Yakutia), 14 years old); “... if you do not know your native language, then I have no right to call myself a Kabardian. And I will not be able to explain to my child what needs to be studied ..." (a student from the Kabardino-Balkarian Republic, 14 years old); “...the native language is the heritage of the people, it keeps all the history we have passed" (a student from the Chechen Republic, 14 years old).

Preliminary results of the survey show that among children in the regions under study the native language tends to be used in everyday communication. Thus, over $59 \%$ of the surveyed students claim that they speak their native language in the family, communicating with parents and relatives. At the same time, children more often refer to their native (national) language speaking with their parents rather than with their friends (peers). It should be noted that the number of questionnaires in the given regions was equal, which does not violate the principle of a pilot research.

The research program implies three stages by year:

Stage I - 2021 - conducting a pilot study;

Stage II - 2022 - research of polylingual education implemented in preschool educational institutions; focus group interviews;

Stage III - 2023 - research of multilingual education in organizations of primary and basic general education; expert semi-formalized interviews.

Conducting a pilot study on this problem in 2021 was due to the need to collect statistical information, verify the validity of the tasks and hypotheses put forward, identify individual characteristics of the object in order to determine the most stable ones for their further in-depth development.

A secondary analysis of sociological research data allows us to supplement the information collected during the study, confirm or refute the hypotheses of the study, and consider the problems under study in a more versatile way. 
In order to implement the pilot study, diagnostic materials were developed that allowed for comparable data collection in 7 regions of the country.

In 2021, the pilot study was conducted in a mixed format, the following methods being used:

- content analysis of documentation regulating the educational process in the regions;

- collection and analysis of statistical data regarding the assessment of institutional support for the development of polylingual and multicultural education in 7 studied subjects of Russia (state programs, concepts, regulations, etc.);

- analysis of materials of educational and methodological support of polylingual education in organizations of primary and basic general education;

- analysis of the results of students' achievements, in particular, the results of the AllRussian Olympiad of Schoolchildren in Russian and Foreign Languages, All-Russian testing works, state final certification;

- a survey of experts, represented by teachers of general education institutions implementing language disciplines (people);

- testing of 1000 students in the $4^{\text {th }}$ and the $8^{\text {th }}$ grades of general education institutions on the quality of coping with the curricula in native and foreign languages (tests of levels A1 and A2 in accordance with the Common European Framework of Reference for Languages).

It should be noted that of the 7 regions studied, three: The Chechen Republic, the Republic of North Ossetia-Alania, the Republic of Tatarstan, back in 2008, took part in the implementation of a Comprehensive Program for the development of multicultural education, developed on the basis of a conceptual idea of ways to modernize Russian education. According to this Program, a full-fledged multicultural education «forms the content of education and upbringing within the framework of a single state standard in accordance with the construction of Russian identity, while the ethno-cultural heritage and national cultures of the peoples of Russia are broadcast in a broad all-Russian and world cultural and civilizational context according to the general formula "a region - Russia - the world". It is this triad ("a region - Russia - the world") in its various variations that determines the models of polylingual education.

The analysis of the results of the pilot studies allows us to talk about three models currently used in polylingual education in the studied regions. All the three models are built from the methodological point of view - on the implementation of the Federal State Educational Standard of primary and basic general education (the level of secondary general education in the institutions of the analyzed regions is not represented), from the ideological and content viewpoint - on the formation of an all-Russian civic identity that has integrated national cultures of the peoples of Russia, and is an integral part of the world culture. It is worth noting that any model does not involve the organization of different separate components in the context of "region - country", but, on the contrary, ensures the inclusion of a regional educational content into the federal component, which ensures selfidentification of students both at the regionalterritorial and national levels.

In general, the choice of a particular model by educational institutions is determined by two factors:

1. The level of institutional support of regional authorities;

2. The degree of proficiency of students in their native and Russian languages.

The analysis of legislation and regulatory legal acts of the 7 above-mentioned subjects of the Russian Federation suggests that support in the development of Russian, native languages and languages of other 
peoples living in the republics is generally provided. All seven subjects have adopted laws "On education", as well as regional state programs for the development of education, which give place to the development of language education.

In 6 of the 7 regions under consideration, regional laws on the languages of the peoples of the corresponding region have been adopted, which reflect the state languages, official languages (for example, in the Republic of Sakha, where, along with 2 state languages (Russian, Sakha), 5 official languages are established) and the languages of the peoples living in the designated subject of the Russian Federation. The only exception is the Republic of North Ossetia Alania, where, with a sufficiently developed regulatory framework in the field of language policy and a clear consolidation of the state languages (Ossetian and Russian) in the Constitution of the Republic, there is no regional law on languages, due to ongoing discussions about the status of the Digor variant of the Ossetian language.

It is noteworthy that in all the three republics of the North Caucasus there are no existing state programs for the preservation, study and development of the languages of the region recognized as state ones. At the same time, in the 90 s and early 2000s, similar regulations were in force on the territory of the Chechen and Kabardino-Balkarian republics. In the analyzed regions of the Ural-Volga region and in the Republic of Sakha (Yakutia), there do exist programs for the development of the state languages of the republics and the languages of the peoples living in the corresponding region.

As for the very concept of "polylingual education" and related by-law, regulatory legal acts, as officially approved by the executive authority, the concept of multilingual education has been adopted in the republics of Bashkortostan, Tatarstan and the Chechen
Republic (in the latter it is formulated as the concept of multicultural education). In the Chuvash Republic, the processes in the field of education are determined by the program document "Strategies for the development of education in the Chuvash Republic until 2040" which uses the term "polylingualism", but its content is narrowed by the need to master a foreign language. In particular, the above Strategy indicates that "the development of polylinguism and the formation of a person who speaks several languages are among the most important tasks of modern school education. The formation of an open democratic and civil society, foreign economic relations with the countries of the world necessitate the development of foreign languages". There are no officially approved concepts at the state level in the KabardinoBalkarian Republic, in the republics of Sakha (Yakutia) and North Ossetia-Alania. At the same time, there is a project of multilingual education developed by the Yakut Pedagogical College named after S. F. Gogolev "Children of the Arctic: polylingual education", in accordance with which the "International Arctic School" started its work in 2020-2021 academic year.

In the Republic of North Ossetia-Alania, the Concept of the development of polylingual education was developed by the staff of the UNESCO Department of Polylingual and Multicultural Education. In this subject of the Russian Federation, the work on the concept of polylingual education began in 2005. The polylingual approach is understood by the developers as the integration of the diversity of cultures and languages that create an educational environment, ensuring the formation of a scientific and cultural picture of the world for the future generation, starting from preschool age. The conceptual principle (triad) "Ossetia-Russiathe World", which is the basis of the polylingual model of multicultural education, corresponds to 
the natural cognitive needs of students and allows them to realize themselves as citizens of the republic, Russia and the world, with the Ossetian culture fitting into the global cultural space as its harmonious part (T. T. Kambolov). In North Ossetia, educational and methodological kits have been published in many subjects in accordance with the theoretical provisions of the Concept of the Development of Polylingual Education, completed lines of textbooks have been developed and published, as well as bilingual dictionaries in many fields of sciences (for example, V. I. Abaev Ossetian-Russian Dictionary; L. B. Gatsalova, L. K. Parsieva Ossetian-Russian, RussianOssetian Dictionary; A. B. Skodtaev RussianOssetian, Ossetian-Russian school Explanatory Dictionary of Mathematical Terms, etc. ${ }^{8}$. The lines of textbooks on the Ossetian language (for preschool institutions and for grades 1-11) are designed in two versions: for those who speak and those who do not speak the Ossetian language. Separate lines of textbooks on the native language for the Iron and Digor dialects have been published. These textbooks have passed regional pedagogical, scientific, and public expertise.

At the same time, the analysis showed that the development potential is far from being exhausted, it is necessary to promote the search for ways of further development, to point out certain shortcomings in programs and teaching kits. For example, in programs in philological disciplines realized in Ossetia, there is a certain degree of non-synchronous study of topics in the Ossetian and Russian languages. In our work, we proceed from the fact that the Concept is not only a theoretical document - in accordance with it, training is conducted in a number of schools, and

\footnotetext{
${ }^{8}$ Abaev V. I. Russian-Ossetian Dictionary. Moscow: "Soviet Encyclopedia", 1970. 586 p. (In Russian);

Gatsalova L. B., Parsieva L. K. The Great Russian-Ossetian Dictionary. Vladikavkaz, IPO SOIGSI, 2011. 687 p. (In Russian);
}

with different models of polylingual education, which together gives a tangible result.

It is also worth noting the fact that only in two regions, Tatarstan and Bashkortostan, their polylinguality is clearly indicated in the names of schools. There are currently two of them in the Republic of Tatarstan: the state autonomous educational institution Multilingual complex "Adymnar - the way to knowledge and consent" and the municipal autonomous educational institution Multilingual educational Complex "Adymnar - Alabuga" of the Yelabuga municipal district of the Republic of Tatarstan. Both educational institutions were opened in 2020 and are under the patronage of the Chairman of the Board of Trustees of the Republican Renaissance Foundation, the first President of Tatarstan, State Counselor of the Republic of Tatarstan M. Sh. Shaimiev. In the Republic of Bashkortostan, the opening of a network of polylingual multidisciplinary schools is one of the strategic directions of the socio-economic development of the Republic of Bashkortostan until 2024 being implemented in accordance with the Decree of the Head of the Republic of Bashkortostan dated September 23, 2019 No. UG-310. In 2020, 2021, four multilingual schools were opened (two in Ufa, one in Sterlitamak and one in Neftekamsk), in three of them, the native language is Bashkir, while in Neftekamsk, it is Tatar. Although there are no general education institutions in other regions that have the nominal status of polylingual, they represent schools that implement certain polylingual models: to a greater extent, in the Republics of North OssetiaAlania, Sakha (Yakutia), the Chechen Republic,

Skodtaev K. B. Russian-Ossetian, Ossetian-Russian school explanatory dictionary of mathematical terms. Vladi-kavkaz, OlimpGod, 2006. 379 p. (In Russian) 
to a lesser extent in the Kabardino-Balkarian Republic and in Chuvashia. The same can be noted with regard to preschool educational organizations: despite the fact that there are currently no institutions with an official polylingual status in the regions, some kindergartens have been specified for interaction with polylingual schools.

In all the regions, much attention is paid to developing and improving the educational and methodological kits (EMK), elaborating textbooks on different subject lines. Tatarstan has made the most progress in the latter direction: 89 textbooks on the Tatar language and literature are included into the federal list of textbooks, 24 teaching kits are used as a teaching aid, and 79 teaching materials translated into Tatar are used in the educational process for primary and basic general education. In 2021, applications were submitted for inclusion of 38 EMKs for primary general education into the federal list of textbooks.

If we consider the second indicator - the degree of proficiency in the native language of school students, we can note that, on the one hand, it largely depends on the regional institutional support of the language environment, on the other hand, it determines the models in the implementation of polylingual education, among which, within the framework of the analysis, we distinguished the following three ones:

- "a native language - the Russian language - a foreign language";

- "the Russian language - a native language - a foreign language";

- "the Russian language - a native language and a foreign language".

The first model of polylingual education, which can be schematically reflected as follows: "a native language - the Russian language - a foreign language", is aimed at students whose level of proficiency in their native language is higher than the level of proficiency in Russian. This model assumes that in the $1^{\text {st }}$ and $2^{\text {nd }}$ grades, instruction is conducted in the native language in all subjects, except for Russian and literary reading in Russian. It is important to note that the teaching of the Russian language is based on the methodology of teaching a non-native language. As a subject of study, a foreign language is added in the $2^{\text {nd }}$ grade and a foreign language teaching is mainly based on the native language of the students. In grades 3-4, the educational process becomes bilingual, which involves the introduction of teaching some subjects in Russian (normally, when introducing new material, explaining a new topic, the lesson is conducted in the native language, and when fixing and repeating the material - in Russian). The teaching of a foreign language is conducted with reference to the native and Russian languages. So, by the end of primary school, the level of Russian language proficiency is not inferior to the level of a native language proficiency, and students are prepared to study in Russian in basic school. Further, starting from the 5th grade, the educational process is mainly based on Russian. At the same time, in order to form students' general cultural competencies and develop their speech skills in their native language, a number of subjects (the native language and literature, fine arts, music, technology) continue to be taught in their native language. In addition, subjects or their sections of a local history character (history of the region, geography of the region) are taught in their native language. The teaching of a foreign language is conducted with reference only to the Russian language.

There is currently no implemented practice of teaching secondary general education students (grades 10-11) in the analyzed regions according to this polylingual model. However, the available practices presented in different regions consider 
the organization of the educational process in all subjects in Russian and foreign languages, leaving extracurricular time to the native language.

Thus, according to the given concept of polylingual education, at the primary level, the preference is given to the native language with a gradual alignment of positions with the Russian language by the end of primary school and the further predominance of the Russian language in basic and secondary schools with the teaching of a number of subjects in native and foreign languages.

\section{The second model of polylingual} education has become the most widespread in the national regions of Russia. It is focused on students whose native language proficiency is lower than their Russian language proficiency and, in principle, is at an elementary level. According to this model, all subjects in the $1^{\text {st }}$ and the $2^{\text {nd }}$ grades are taught in Russian. The exceptions are the subjects "the Native language" and "Literary reading in the native language", the teaching of the native language in which is carried out according to the methodology of teaching a non-native language. Elements of the native language are included in the process of teaching a number of subjects in grades 3 and 4 and continues in the basic school. A foreign language is studied in both primary and secondary schools as a subject.

Preliminary results of our pilot study showed that, for example, in the Republic of North Ossetia-Alania, there are no significant differences in the level of Russian language proficiency among the 4th grade students in schools realizing different models of polylingual education. It seems that the reason for this is the use of the Russian language in all spheres of a child's life. A comparison of the native language proficiency of 4th grade students demonstrates a big difference in the proficiency of the Ossetian language among schoolchildren studying in accordance with the first and the second models. Diagram 1 shows the results of testing of the 4th grade students in reading in the Ossetian language, writing in the Ossetian language, the maximum and minimum total scores in testing proficiency in the Ossetian language. The first research model is used in "Alan Gymnasium", the second - in "Gymnasium "Dialog" (both schools are located in Vladikavkaz).

Diagram 1

Results of testing of 4th grade students in reading and writing in the Ossetian language

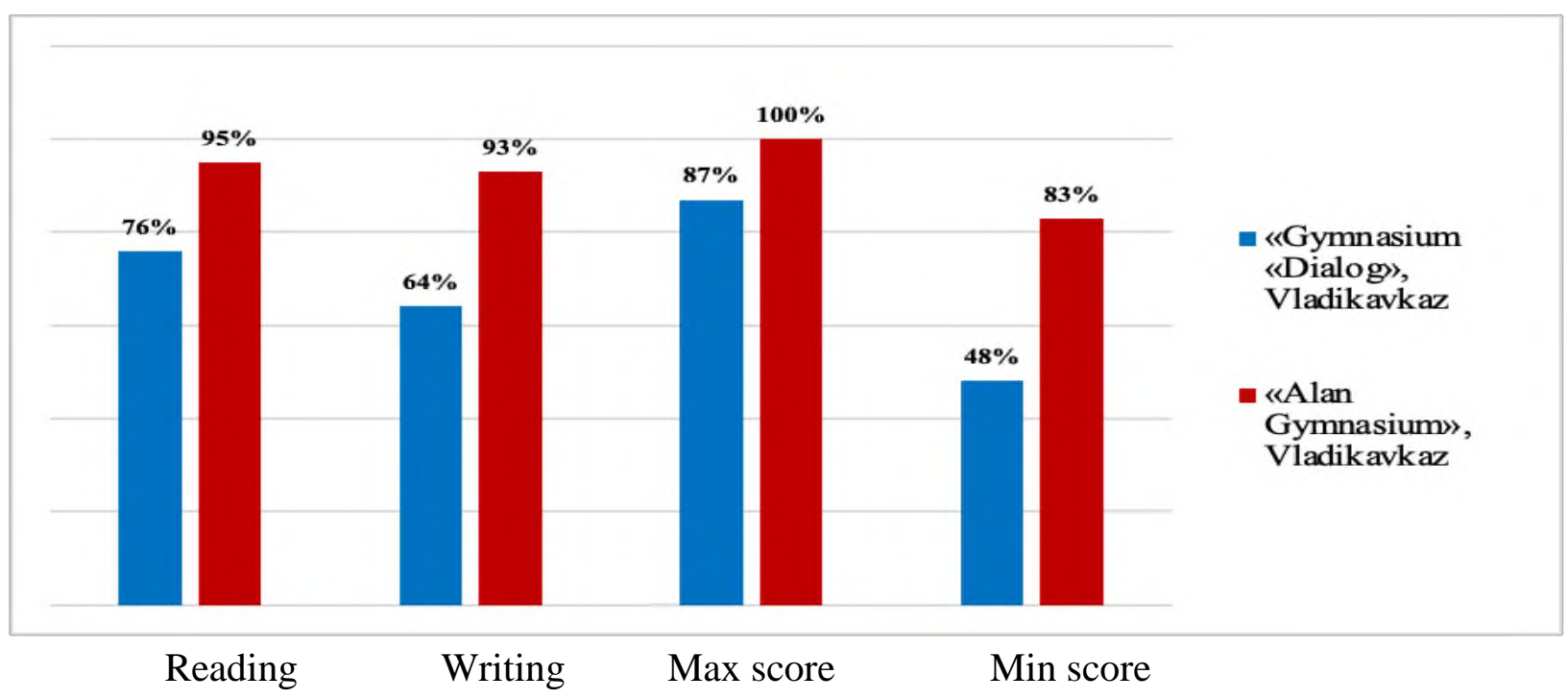


The test results show that the students representing "Alan Gymnasium" speak Ossetian at the level of $94 \%$, while the students of the "Gymnasium "Dialog" - around $70 \%$. At the same time, the difference in "reading" and "writing" among the representatives of the "Alan Gymnasium" is insignificant and is within the sampling error, whereas the difference among the students of "Gymnasium "Dialog" is more than $12 \%$. In addition, while the minimum score for the students of the first model is $83 \%$ with a 100 percent maximum score, the students of the second model have a maximum score closer to the minimum of "Alan Gymnasium", and the minimum score of the "Gymnasium "Dialog" does not exceed the 50 percent barrier. It is noteworthy that the level of reading in the native language is higher than the level of writing. This may be due to the productive, and therefore more complex nature of writing as a type of speech activity, as well as the fact that "Alan Gymnasium", in particular, pays great attention to the development of students' communicative competence in different languages, to their familiarization with national traditions and universal values. The same situation regarding the native language proficiency is observed in comparison of the first and the second models of polylingual education, for example, in the Chechen Republic, the Republic of Sakha and the Republic of Tatarstan.

The third polylingual model provides not only in-depth study of Russian, English and native languages, but also the teaching of other subjects in all the three languages. While in primary school this model repeats the second one to a greater extent, in basic school and especially in secondary school, subjects of mathematical profile (algebra, geometry) and of natural science profile (biology, geography) are taught in a foreign language. Despite the emphasis on studying and teaching in
Russian and English, these educational institutions also provide the study of the native language, literature in the native language and a second foreign language.

It can be said that the second and the third models "came out" of the Soviet system of schools with in-depth study of a foreign language and were successfully reworked taking into account the study of native languages. It was this fact that made it possible to conduct pilot studies in all the regions in 2021, for the ideas and principles of multicultural education are successfully implemented not only in educational institutions having the official status of a polylingual school, but also, as already mentioned, in a number of secondary schools with in-depth study of foreign languages, as well as schools with the teaching of several native languages.

\section{Discussion. Conclusions}

The experience of introducing polylingual educational models in the schools of the regions under study is generally assessed as positive by both teachers and high school students, so as it provides better acquisition of the material, especially in elementary school. At the same time, a number of problem areas are indicated, among which, first of all, are pedagogical personnel capable of conducting educational activities (especially in subject lines) equally qualitatively in Russian, in their native language, and in English. The problem is aggravated by the fact that multilingual schools are only at the initial stage of their development, higher education institutions do not train universal language and subject specialists, and retraining takes time and efforts. The second problematic issue is the edition of textbooks and teaching aids in native languages, which for some regions may not cause great financial difficulties (for example, Bashkortostan, Tatarstan), whereas for most 
regions, the issues of financing textbooks edition for polylingual schools, despite the deep methodological study of the issue (Chechnya, North Ossetia) or partial elaboration of methodological support (Sakha, KabardinoBalkaria, Chuvashia) are quite acute due to the deficit of regional budgets. Also, in some regions, experts highlight as problems the lack of teachers of the languages of the small peoples of the Far North (the Republic of Sakha), the lack of a system of advanced training for teachers in the framework of a polylingual model (KabardinoBalkaria), the situation with the grammatical component of school students' communicative competences in Russian and foreign languages, especially in remote rural settlements (Chechnya), the need for specific recommendations on relevant subjects, bi- or multilingual textbooks, manuals, control and measuring materials (Bashkortostan), the lack of scientific and methodological support for teachers of polylingual schools and the possibility of outflow of graduates of polylingual schools to other regions and countries (Tatarstan), the lack of a systematic approach to the implementation of polylingual education as such (the Republic of Chuvashia), the closure of the North Ossetian Pedagogical Institute.

In the course of research, the following scientific results were obtained:

1. Diagnostic materials have been developed for the organization of a comparative analysis of the practices of implementing multilingual education in the regions of the Russian Federation: checklists for assessing institutional support for the development of multilingual and multicultural education in the studied regions, checklists for the study of educational and methodological support of multilingual education in primary and basic general education organizations, questionnaires for students and teachers implementing language disciplines, tests in foreign and native languages.

2. Field studies of the practices of implementing multilingual education in the regions (Republic of Bashkortostan, KabardinoBalkar Republic, Republic of Sakha (Yakutia), Republic of North Ossetia-Alania, Republic of Tatarstan, Chechen Republic, Chuvash Republic) were conducted: collection and analysis of the material based on the application of the developed diagnostic device.

3. The main types of models of multilingual education implemented in the studied regions are determined. In particular, the models presented in the Republic of North Ossetia-Alania, the Republic of Tatarstan and the Republic of Sakha (Yakutia) are the most developed of them and have had experience of implementation for several years.

The conducted research has shown that there is no absolutely effective model in the Russian Federation for the development of polylingual training. Besides, for the development of the Concept of polylingual education, it is necessary to take into account sociodemographic, socio-cultural, ethno-confessional and religious aspects, which will allow textbook developers to better adapt the material for schoolchildren.

To achieve more precise conclusions, the research group of Bashkir State Pedagogical University named after M. Akmulla continues to work on studying the models of polylingual education being applied in the regions of Russia, in order to develop the Concept of polylingual education. 


\section{REFERENCES}

1. Sagitov S. T., Nasibullin R. T., Bakhtizin R. N. Priority ranking of social systems in managing the sociocultural processes: public opinion. Revista Inclusiones: Revista de Humanidades y Ciencias Sociales, 2020, vol. 7, pp. 697-710. ISSN 0719-4706 URL: https://revistainclusiones.org/index.php/inclu/article/view/1446

2. Sagitov S. T. The role of public opinion in the process of managing the sphere of culture. Sociology, 2017, no. 4, pp. 100-105. (In Russian) URL: https://www.elibrary.ru/item.asp?id=36983849\&

3. Kirss L., Saalik U., Leijen A., Pedaste M. School effectiveness in multilingual education: A review of success factors. Education Sciences, 2021, vol. 11 (5), pp. 193. DOI: https://doi.org/10.3390/educsci11050193

4. Van Avermaet P., Slembrouck S., Van Gorp K., Sierens S., Maryns K. (eds) The Multilingual Edge of Education. Palgrave Macmillan, 2018. 374 p. DOI: https://doi.org/10.1057/978-1-137-54856-6

5. Piccardo E., Germain-Rutherford A., Lawrence G. (eds) The Routledge Handbook of Plurilingual Language Education. New York, NY: Taylor and Francis, 2021. 534 p. DOI: https://doi.org/10.4324/9781351002783

6. Brisk M. E. (eds) Language in Writing Instruction: Enhancing Literacy in Grades 3-8. Milton: Taylor and Francis, 2020. 198 p. DOI: https://doi.org/10.4324/9780429397769

7. Hammer S., Viesca K. M., Commins N. L. (eds) Teaching Content and Language in the Multilingual Classroom: International Research on Policy, Perspectives, Preparation and Practice. Taylor and Francis, 2019. 218 p. DOI: https://doi.org/10.4324/9780429459443

8. Kourtis-Kazoullis V., Aravossitas T., Skourtou E., Trifonas P. P. (eds) Interdisciplinary Research Approaches to Multilingual Education, Taylor and Francis, 2018. 306 p. DOI: https://doi.org/10.4324/9781351170086

9. Curdt-Christiansen X. L., Wang W. Parents as agents of multilingual education: Family language planning in China». Language, Culture, and Curriculum, 2018, vol. 31 (3), pp. 235-254. DOI: https://doi.org/10.1080/07908318.2018.1504394

10. Breuer E. O., Lindgren E., Stavans A., Van Steendam E. (eds) Multilingual Literacy, 2021. 304 p. DOI: https://doi.org/10.21832/9781800410701

11. Gao X., Zheng Y. Multilingualism and higher education in Greater China. Journal of Multilingual and Multicultural Development, 2019, vol. 40 (7), pp. 555-561. DOI: https://doi.org/10.1080/01434632.2019.1571073

12. Duarte J., Günther-van der Meij M. A holistic model for multilingualism in education. E-JournALL, EuroAmerican Journal of Applied Linguistics and Languages, 2018, vol. 5 (2), pp. 24-43. DOI: https://doi.org/10.21283/2376905X.9.153

13. Wang L., Kirkpatrick A. Trilingual education in Hong Kong primary schools: An overview. Multilingual Education, 2015, vol. 5, pp. 3. DOI: https://doi.org/10.1186/s13616-015-0023-8

14. $\mathrm{Xu} \mathrm{H}$, Shan $\mathrm{Z}$. Teaching and learning multiple varieties of a foreign language for sustainable multilingual education. Sustainability, 2021, vol. 13 (14), pp. 8004. DOI: https://doi.org/10.3390/su13148004

15. Schwartz M. Preschool bilingual education agency in Interactions between children, teachers, and parents. Springer, 2018. 374 p. ISBN: 978-3-319-77228-8 DOI: https://doi.org/10.1007/978-3319-77228-8

16. Zhang L., Tsung L. Bilingual education and minority language maintenance in China. The Role of Schools in Saving the Yi Language. Springer, 2019. 165 p. ISBN: 978-3-030-03454-2 DOI: https://doi.org/10.1007/978-3-030-03454-2 
17. Teng M. F. Identity, Motivation, and Multilingual education in Asian contexts, 2020. 193 p. DOI: https://doi.org/10.5040/9781350099685

18. Hollebeke I., Struys E., Agirdag O. Can family language policy predict linguistic, socio-emotional and cognitive child and family outcomes? A systematic review. Journal of Multilingual and Multicultural Development, 2020. Latest Articles. DOI: https://doi.org/10.1080/01434632.2020.1858302

19. Paulsrud B., Zilliacus H., Ekberg L. Spaces for multilingual education: Language orientations in the national curricula of Sweden and Finland. International Multilingual Research Journal, 2020, vol. 14 (4), pp. 304-318. DOI: https://doi.org/10.1080/19313152.2020.1714158

20. Cenoz J., Leonet O., Gorter D. Developing cognate awareness through pedagogical translanguaging. International Journal of Bilingual Education and Bilingualism, 2021, Latest Articles, pp. 1-15. DOI: https://doi.org/10.1080/13670050.2021.1961675

21. Aronin L. Challenges of multilingual education: streamlining affordances through dominant language constellations. Stellenbosch Papers in Linguistics Plus, 2019, vol. 58, pp. 235-256. DOI: https://doi.org/10.5842/58-0-845

22. Bolton K. Language policy and planning in Hong Kong: Colonial and post-colonial perspectives. Applied Linguistic Review, 2011, vol. 2, pp. 51-74. DOI: https://doi.org/10.1515/9783110239331.51

23. Adinolfi L., Phyak P., Bhattacharya U. Multilingual Education in South Asia: At the Intersection of Policy and Practice. Taylor and Francis, 2022. 216 p. DOI: https://doi.org/10.4324/9781003158660

24. Gorter D., Cenoz J. Language education policy and multilingual assessment. Language and Education, 2016, vol. 31 (3), pp. 231-248. DOI: https://doi.org/10.1080/09500782.2016.1261892

25. Wang L. Trilingual education in Hong Kong secondary schools: A case study. Silk Road: A Journal of Eurasian Development, 2020, vol. 2 (1), pp. 18-34. DOI: https://doi.org/10.16997/srjed.10

Submitted: 19 November 2021 Accepted: 10 January 2022 Published: 28 February 2022

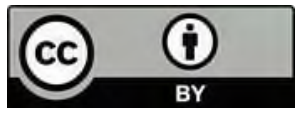

This is an open access article distributed under the Creative Commons Attribution License which permits unrestricted use, distribution, and reproduction in any medium, provided the original work is properly cited. (CC BY 4.0).

\section{The authors' stated contribution:}

Raisa Mingazitdinovna Iksanova

Contribution of the co-author: responsible executor of the research project, senior researcher; collection of empirical material of the presented research, writing the text of the article.

Zarima Rinatovna Kireeva

Contribution of the co-author: senior researcher; collection of empirical material of the presented research, writing the text of the article.

Eduard Irekovich Sattarov

Contribution of the co-author: junior researcher; data processing of empirical material and writing the text of the article. 
Salavat Talgatovich Sagitov

Contribution of the co-author: management of the research project; collection of empirical material of the presented research, data processing and writing the text of the article.

\section{Information about competitive interests:}

The authors claim that they do not have competitive interests.

\section{Information about the Authors}

\section{Raisa Mingazitdinovna Iksanova}

Candidate of Philological Sciences, Associate Professor, Head of the

Department,

Department of English,

Bashkir State Pedagogical University named after M. Akmulla,

October Revolution str., 3-a, 450008, Republic of Bashkortostan, Ufa, Russian Federation.

ORCID ID: https://orcid.org/0000-0002-4517-937X

E-mail: iks_raichka@mail.ru

\section{Zarima Rinatovna Kireeva}

Candidate of Pedagogical Sciences, Associate Professor,

Department of Methods of Teaching Foreign Languages and a Second Foreign Language,

Bashkir State Pedagogical University named after M. Akmulla,

October Revolution str., 3-a, 450008, Republic of Bashkortostan, Ufa, Russian Federation.

ORCID ID: https://orcid.org/0000-0002-5016-7365

E-mail: metodika-fr@yandex.ru

\section{Eduard Irekovich Sattarov}

Director,

Analytical Center,

Bashkir State Pedagogical University named after M. Akmulla,

October Revolution str., 3-a, 450008, Republic of Bashkortostan, Ufa, Russian Federation.

ORCID ID: https://orcid.org/0000-0002-4489-6369

E-mail: sattarov.eduard@mail.ru

\section{Salavat Talgatovich Sagitov}

Candidate of Sociological Sciences, Rector,

Bashkir State Pedagogical University named after M. Akmulla,

October Revolution str., 3-a, 450008, Republic of Bashkortostan, Ufa, Russian Federation.

ORCID ID: https://orcid.org/0000-0002-7211-1004

E-mail: salavatst@list.ru (Corresponding Author) 


\title{
Изучение практик внедрения полилингвальной модели поликультурного образования на территории Российской Федерации
}

\author{
Р. М. Иксанова ${ }^{1}$, 3. Р. Киреева ${ }^{1}$, Э. И. Саттаров ${ }^{1}$, С. Т. Сагитов $\beth^{1}$ \\ ${ }^{1}$ Башкирский государственный педагогический университет \\ имени Мифтахетдина Акмуллы, Уфа, Россия
}

Проблема и цель. В статье рассматриваются практики внедрения полилингвальной модели поликультурного образования на территории Российской Федерации. Как известно, Российская Федераџия многонаџиональная и лингвистически разнообразная страна. В России офиииальный язык - русский, 37 государственных языков в республиках Российской Федерации; более 15 языков с официальным статусом. Для ряда регионов страны модель полилингвального обучения крайне актуальна. Цель статьи - изучение практик внедрения полилингвальной модели поликультурного образования на территории Российской Федерачии, их сравнительный анализ.

Методология. В рамках исследования проводился анализ нормативных документов, регламентирующих прочессы поликультурного и полилингвального образования в Республике Северная Осетия - Алания, Кабардино-Балкарской Республике, Чеченской Республике, Республике Саха (Якутия), Республике Татарстан, Чувашской Республике, Республике Башкортостан (государственные программы, концепиии, положения и др.), организовывались круглье столы и беседы с научно-педагогическим сообществом регионов, изучались учебные планы образовательных организаций, программы и учебно-методические комплекты по языковым дисииплинам, реализуемым в СОО, посещались уроки, проводилось анкетирование и тестирование обучающихся начальной (4 класс) и основной школ (8 класс) по иностранным и родным языкам, анализировались результаты достижений обучающихся (результать Всероссийской олимпиады школьников по русскому и иностранным языкам, Всероссийских проверочных работ, государственной итоговой аттестации, единого государственного экзамена).

Результаты. Результаты заключаются в определении основных типов моделей полилингвального образования, реализуемых в исследуемых регионах. В частности, наиболее

Финансирование проекта: Исследование выполнено в рамках проекта государственного задания Министерства просвещения Российской Федерации № 073-03-2021-015/2 от 21.07.2021 г. на выполнение научно-исследовательской работы по теме «Сравнительный анализ практик внедрения полилингвальной модели поликультурного образования».

Библиографическая ссылка: Иксанова Р. М., Киреева 3. Р., Саттаров Э. И., Сагитов С. Т. Изучение практик внедрения полилингвальной модели поликультурного образования на территории Российской Федерации // Science for Education Today. - 2022. - Т. 12, № 1. - C. 125-149. DOI: http://dx.doi.org/10.15293/2658-6762.2201.06

曰@ Автор для корреспонденции: Салават Талгатович Сагитов, salavatst@ list.ru

(C) Р. М. Иксанова, 3. Р. Киреева, Э. И. Саттаров, С. Т. Сагитов, 2022 


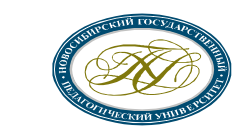

Science for Education Today

2022. Том 12. № 1 http://sciforedu.ru/

ISSN 2658-6762

разработанными из них и имеющими опыт внедрения в течение нескольких лет являются модели, представленные в Республике Северная Осетия - Алания, Республике Татарстан и Республике Саха (Якутия). Полученные результаты помогут достичь большего понимания специфики полилингвального образования в России, а само исследование способствует теоретическому вкладу в изучение полилингвального образования в цуелом.

Заключение. В заключении делается вывод, что в настоящее время в школах России нет согласованной модели внедрения полилингвального образования. Развитие полилингвальной модели поликультурного образования в первую очередь нацелено на сохранение и дальнейшее развитие родного языка в субъектах Российской Федераџии, что остается одной из важнейших задач не только решения узко этнокультурных вопросов, но и в контексте сохранения естественной поликультурной основы многонационального российского государства.

Ключевые слова: полилингвальное образование; полилингвальная модель; практика внедрения полилингвальной модели; поликультурная среда; сравнительный анализ практик внедрения полилингвальной модели; система образования; родной язык.

\section{СПИСОК ЛИТЕРАТУРЫ}

1. Sagitov S. T., Nasibullin R. T., Bakhtizin R. N. Priority ranking of social systems in managing the sociocultural processes: public opinion // Revista Inclusiones: Revista de Humanidades y Ciencias Sociales. - 2020. - Vol. 7. - P. 697-710. ISSN 0719-4706 URL: https://revistainclusiones.org/index.php/inclu/article/view/1446

2. Сагитов С. Т. Роль общественного мнения в процессе управления сферой культуры // Социология. - 2017. - №. 4. - C. 100-105. URL: https://www.elibrary.ru/item.asp?id=36983849\&

3. Kirss L., Saalik U., Leijen A., Pedaste M. School Effectiveness in Multilingual Education: A Review of Success Factors // Education Sciences. - 2021. - Vol. 11 (5). - P. 193. DOI: https://doi.org/10.3390/educsci11050193

4. Van Avermaet P., Slembrouck S., Van Gorp K., Sierens S., Maryns K. (eds) The Multilingual Edge of Education. - Palgrave Macmillan, 2018. - 374 p. DOI: https://doi.org/10.1057/978-1-137-54856-6

5. Piccardo E., Germain-Rutherford A., Lawrence G. (eds) The Routledge Handbook of Plurilingual Language Education. - New York, NY: Taylor and Francis, 2021. - 534 p. DOI: https://doi.org/10.4324/9781351002783

6. Brisk M. E. (eds) Language in Writing Instruction: Enhancing Literacy in Grades 3-8. Milton: Taylor and Francis, 2020. - 198 p. DOI: https://doi.org/10.4324/9780429397769

7. Hammer S., Viesca K. M., Commins N. L. (eds) Teaching Content and Language in the Multilingual Classroom: International Research on Policy, Perspectives, Preparation and Practice. - Taylor and Francis, 2019. - 218 p. DOI: https://doi.org/10.4324/9780429459443

8. Kourtis-Kazoullis V., Aravossitas T., Skourtou E., Trifonas P. P. (eds) Interdisciplinary Research Approaches to Multilingual Education. - Taylor and Francis, 2018. - 306 p. DOI: https://doi.org/10.4324/9781351170086 


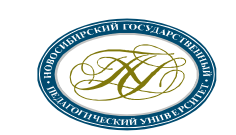

Science for Education Today

9. Curdt-Christiansen X. L., Wang W. Parents as Agents of Multilingual Education: Family Language Planning in China // Language, culture, and curriculum. - 2018. - Vol. 31 (3). P. 235-254. DOI: https://doi.org/10.1080/07908318.2018.1504394

10. Breuer E. O., Lindgren E., Stavans A., Van Steendam E. (eds.) Multilingual literacy, 2021. - 304 p. DOI: https://doi.org/10.21832/9781800410701

11. Gao X., Zheng Y. Multilingualism and higher education in Greater China // Journal of Multilingual and Multicultural Development. - 2019. - Vol. 40 (7). - P. 555-561. DOI: https://doi.org/10.1080/01434632.2019.1571073

12. Duarte J., Günther-van der Meij M. A holistic model for multilingualism in education // EJournALL, EuroAmerican Journal of Applied Linguistics and Languages. - 2018. Vol. 5 (2). - P. 24-43. DOI: https://doi.org/10.21283/2376905X.9.153

13. Wang L., Kirkpatrick A. Trilingual Education in Hong Kong Primary Schools: an overview // Multilingual Education. - 2015. - Vol. 5. - P. 3. DOI: https://doi.org/10.1186/s13616-015-0023-8

14. Xu H, Shan Z. Teaching and Learning Multiple Varieties of a Foreign Language for Sustainable Multilingual Education // Sustainability. - 2021. - Vol. 13 (14). - P. 8004. DOI: https://doi.org/10.3390/su13148004

15. Schwartz M. Preschool bilingual education agency in Interactions between children, teachers, and parents. - Springer, 2018. - 374 p. ISBN: 978-3-319-77228-8 DOI: https://doi.org/10.1007/978-3-319-77228-8

16. Zhang L., Tsung L. Bilingual education and minority language maintenance in China. The Role of Schools in Saving the Yi Language. - Springer, 2019. - 165 p. ISBN: 978-3-03003454-2 DOI: https://doi.org/10.1007/978-3-030-03454-2

17. Teng M. F. Identity, Motivation, and Multilingual education in Asian contexts, 2020. 193 p. DOI: https://doi.org/10.5040/9781350099685

18. Hollebeke I., Struys E., Agirdag O. Can family language policy predict linguistic, socioemotional and cognitive child and family outcomes? A systematic review // Journal of Multilingual and Multicultural Development. - 2020. DOI: https://doi.org/10.1080/01434632.2020.1858302

19. Paulsrud B., Zilliacus H., Ekberg L. Spaces for multilingual education: language orientations in the national curricula of Sweden and Finland // International Multilingual Research Journal. - 2020. - Vol. 14 (4). $\quad$ - $\quad$ P. 304-318. DOI: https://doi.org/10.1080/19313152.2020.1714158

20. Cenoz J., Leonet O., Gorter D. Developing cognate awareness through pedagogical translanguaging // International Journal of Bilingual Education and Bilingualism. - 2021. P. 1-15. DOI: https://doi.org/10.1080/13670050.2021.1961675

21. Aronin L. Challenges of multilingual education: streamlining affordances through Dominant Language Constellations // Stellenbosch Papers in Linguistics Plus. - 2019. Vol. 58. - P. 235-256. DOI: https://doi.org/10.5842/58-0-845

22. Bolton K. Language policy and planning in Hong Kong: Colonial and post-colonial perspectives // Applied linguistic review. - 2011. - Vol. 2. - P. 51-74. DOI: https://doi.org/10.1515/9783110239331.51 


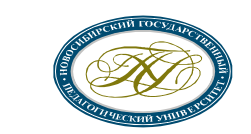

Science for Education Today

2022. Том 12. № 1 http://sciforedu.ru/

ISSN 2658-6762

23. Adinolfi L., Phyak P., Bhattacharya U. Multilingual Education in South Asia: At the Intersection of Policy and Practice. - Taylor and Francis, 2022. - 216 p. DOI: https://doi.org/10.4324/9781003158660

24. Gorter D., Cenoz J. Language education policy and multilingual assessment // Language and Education. - 2016. - Vol. 31 (3). - P. 231-248. DOI: https://doi.org/10.1080/09500782.2016.1261892

25. Wang L. Trilingual Education in Hong Kong Secondary Schools: A Case Study // Silk Road: A Journal of Eurasian Development. - 2020. - Vol. 2 (1). - P. 18-34. DOI: https://doi.org/10.16997/srjed.10

Поступила: 19 Ноября 2021 Принята: 10 января 2022 Опубликована: 28 февраля 2022

\section{Заявленный вклад авторов:}

Иксанова Раиса Мингазитдиновна: ответственный исполнитель научно-исследовательского проекта, старший научный сотрудник; сбор эмпирического материала представленного исследования, написание текста статьи.

Киреева Зарима Ренатовна: старший научный сотрудник; сбор эмпирического материала представленного исследования, написание текста статьи.

Саттаров Эдуард Ирекович: младший научный сотрудник; обработка данных эмпирического материала и написание текста статьи.

Сагитов Салават Талгатович: руководство научно-исследовательским проектом; сбор эмпирического материала представленного исследования, обработка данных и написание текста статьи.

\section{Информация о конфликте интересов:}

Авторы заявляют об отсутствии конфликта интересов.

\section{Информация об авторах}

\section{Иксанова Раиса Мингазитдиновна}

кандидат филологических наук, доцент, заведующий кафедрой, кафедра английского языка,

Башкирский государственный педагогический университет имени Мифтахетдина Акмуллы,

ул. Октябрьской революции, 3-a, 450008, Республика Башкортостан, Уфа, Российская Федерация.

ORCID ID: https://orcid.org/0000-0002-4517-937X

E-mail: iks_raichka@mail.ru 


\section{Киреева Зарима Ренатовна}

кандидат педагогических наук, доцент, кафедра методики преподавания иностранных языков и второго иностранного языка, Башкирский государственный педагогический университет имени Мифтахетдина Акмуллы, ул. Октябрьской революции, 3-a, 450008, Республика Башкортостан, Уфа, Российская Федерация.

ORCID ID: https://orcid.org/0000-0002-5016-7365

E-mail: metodika-fr@yandex.ru

\section{Саттаров Эдуард Ирекович}

директор, аналитический центр,

Башкирский государственный педагогический университет имени Мифтахетдина Акмуллы,

ул. Октябрьской революции, 3-a, 450008, Республика Башкортостан, Уфа, Российская Федерация.

ORCID ID: https://orcid.org/0000-0002-4489-6369

E-mail: sattarov.eduard@mail.ru

\section{Сагитов Салават Талгатович}

кандидат социологических наук, ректор,

Башкирский государственный педагогический университет имени Мифтахетдина Акмуллы,

ул. Октябрьской революции, 3-a, 450008, Республика Башкортостан, Уфа, Российская Федерация.

ORCID ID: https://orcid.org/0000-0002-7211-1004

E-mail: salavatst@list.ru 


\title{
Проблема семантической дислексии у младших школьников с общим недоразвитием речи
}

\author{
С. Г. Карапетян $\square^{1}{ }^{1}$, А. А. Киракосян ${ }^{1}$ \\ ${ }^{1}$ Армянский государственный педагогический университет \\ имени Хачатура Абовяна, Ереван, Армения
}

Проблема и цель. В статье рассматривается проблема нарушений чтения у учашихся $c$ общим недоразвитием речи. Цель исследования состоит в изучении предпосылок нарушений проиесса чтения у младших школьников с общим недоразвитием речи и определении основных направлений логопедической работы по преодолению семантической дислексии.

Методология. Методологической основой исследования выступают труды отечественных и зарубежных исследователей о роли восприятия и понимания текста у школьников с общим недоразвитием речи, их развитии и сочиализации.

Результаты. В результате исследования выявлены особенности проявления семантической дислексии у детей с общим недоразвитием речи III уровня. Восприятие и понимание читаемого текста у детей с общим недоразвитием речи характеризуется разнообразными нарушениями, которые в основном проявляются в неточном знании и употреблении многих слов и выражений, в нарушении понимания смысловых и грамматических взаимоотнотений слов, в затруднении выделения в тексте объекта и субъекта действия, отношения между ними, в нарушении смыслового программирования и языкового оформления текста и т.. .

Заключение. Результаты исследования позволили раскрыть механизм нарушений чтения y детей с общим недоразвитием речи ІІІ уровня и разработать направления и пути коррекиии семантической дислексии.

Ключевые слова: общее недоразвитие речи III уровня; семантическая дислексия; предпосылки для овладения чтением; смысловой компонент чтения; словарный состав текста; концептуальная насыщенность текста; словарный запас; грамматический строй речи; фонетикофонематический прочесс; вербальная память; текст-повествование; текст-описание; импрессивный аграмматизм.

Библиографическая ссылка: Карапетян С. Г., Киракосян А. А. Проблема семантической дислексии у младших школьников с общим недоразвитием речи // Science for Education Today. - 2022. - T. 12, № 1. - C. 150-163. DOI: http://dx.doi.org/10.15293/2658-6762.2201.07

曰Љ Автор для корреспонденции: Сирануш Геворковна Kарапетян, karapetyansiranush56@aspu.am

(C) С. Г. Карапетян, А. А. Киракосян, 2022 


\section{Постановка проблемы}

Проблема изучения нарушений чтения у младших школьников и их преодоления весьма актуальна в настоящее время в научном сообществе [1-5], так как с каждым годом возрастает число детей с общим недоразвитием речи [6-8].

В настоящее время исследователями признано, что значительные трудности в освоении детьми программы школьного обучения являются не только педагогической, но и медицинской проблемой [9-14].

В МКБ-10 расстройства, проявляющиеся изолированным нарушением формирования базовых навыков, необходимых в процессе обучения, выделены в качестве самостоятельной нозологической единицы - «Специфические расстройства развития учебных навыков» (F.81), включающей «Специфическое расстройство чтения» (F81.0; дислексия).

Дислексия (Developmental Dyslexia дислексия развития) - это стойкая, избирательная неспособность овладеть навыком чтения, несмотря на достаточный для этого уровень интеллектуального (и речевого) развития, отсутствие нарушений слухового и зрительного анализаторов и наличие оптимальных условий обучения (М. В. Румянцева ${ }^{1}$, М. А. Хан [15]; С. Ю. Сурушкина, Е. А. Яковенко, Л. С. Чутко, М. Д. Дидур [16]).

Среди нарушений чтения у детей с общим недоразвитием речи особый интерес представляет семантическая дислексия, при

\footnotetext{
${ }^{1}$ Румянцева М. В. Неврологические аспекты дислексии у детей: дисс. .... уч. степени канд. медицинских наук / ГОУВПО “Российский государственный медицинский университет”. - M., 2006. URL: https://elibrary.ru/item.asp?id=16196081

2 Лалаева Р. И. Нарушения чтения и пути их коррекции у младших школьников: учебное пособие. - СПб.: СОЮ3, 1998. - 224 c.
}

которой нарушен смысловой компонент чтения. При семантической дислексии школьники демонстрируют различную степень «недопонимания» текста: от неадекватных лексических замен, логических ошибок и «смысловых скважин» при пересказе до невозможности ответить на вопросы по содержанию прочитанного. Описан и крайний вариант семантической дислексии - «механическое», «бездумное» чтение (Р. И. Лалаева ${ }^{2}$, Н. С. Комарова, О. А. Вилигина, О. А. Козырева, [17], В. Р. Ермакова, В. Г. Колягина [18]).

Дислексия проявляется в раннем школьном возрасте при первых попытках овладения чтением, при этом у детей с общим недоразвитием речи предпосылки к овладению письмом и чтением изначально нарушены: недоразвита языковая система, наблюдаются особенности формирования высших психических функций (Flannery, Liederman et al. [19]; Pennington, [20]).

От успешности обучения чтению зависит не только психическое и когнитивное развитие школьника, но и качество его дальнейшей учебной деятельности ${ }^{3}$.

Процесс семантического восприятия текста - это иерархическая система взаимосвязи низшего, сенсорного, и высшего, смыслового, уровней. Осмысление текста осуществляется при постепенном переходе от интерпретации значений слов к смыслу целых высказываний, а далее к общей идее текста. Процессы понимания слов и фраз являются

\footnotetext{
${ }^{3}$ Иншакова А. Г. Различные типы дислексии и их связь с нарушениями речевого развития у младших школьников // Вестник КГУ им. Н. А. Некрасова. - 2008. Т. 14. - С. 190-192.

Карапетян С. Г., Киракосян А. А. Анализ проблемы письменной речи в начальной школе // European Scientific Conference: сборник статей X Международной научно-практической конференции. Пенза, ч. 2. 2018. - C. $125-128$.
} 
вспомогательными операциями, так как реципиент, обращаясь к тексту, никогда не ставит перед собой задачу понять отдельные слова или фразы (О. С. Зорькина, 2003).

А. Р. Лурия (1979) 4 определяет понимание как декодирование речевого сообщения и раскрывает условия возможности понимания, к которым относит восприятие и понимание отдельных слов, синтаксических связей между словами, целого сообщения.

На понимание читаемого текста значительным образом влияют его языковые параметры: словарный состав текста (А. Р. Лурия ${ }^{5}$, Т. М. Дридзе, А. А. Леонтьев ${ }^{6}$, Г. В. Бабина ${ }^{7}$ ), концептуальная насыщенность текста $\left(\right.$ Р. Флеш, 1976) ${ }^{8}$, возникающая при чтении и уменьшающая трудность его восприятия.

Исследование Г. С. Гуменной и Т. Д. Барменковой ${ }^{9}$, выполненное в контексте обсуждаемой нами проблематики, экспериментально подтверждает наличие у дошкольников с общим недоразвитием речи корреляции между степенью выраженности речевого недоразвития и уровнем сформированности у них операций осмысления и расчленения проблемной ситуации текста, смысловой переработки информации и программирования собственного высказывания.

4 Лурия А. Р. Язык и сознание / под ред. Е. Д. Хомской. - М.: Изд. МГУ, 1979. - С. 148.

5 Лурия А. Р. Письмо и речь: Нейролингвистические исследования: учеб. пособие для студ. психол. фак. высш. учеб. заведений. - М., 2002. - С. 232-263.

Лурия А. Р. Язык и сознание / под ред. Е. Д. Хомской. - М.: Изд. МГУ, 1979. - С. 217-226.

${ }^{6}$ Смысловое восприятие речевого сообщения (в условиях массовой коммуникации) / отв. ред. Т. М. Дридзе, А. А. Леонтьев. - М.: Наука, 1976.

${ }^{7}$ Бабина Г. В. Усвоение структурно-семантических параметров речевого произведения учащимися с нарушением чтения // PROчтение: дислексия в XXI веке: сборник материалов IX Международной научнопрактической конференции Российской ассоциации дислексии (10 сентября 2020 г., Москва) / под общ.
Анализируя процесс декодирования текста младшими школьниками с общим недоразвитием речи, В. В. Строганова ${ }^{10}$ обнаруживает трудности указывания ими текстовых сообщений, фрагментарность расшифровки отдельных компонентов текста, нарушения поверхностных и глубинных связей между его частями. Их наличие и довольно частотная представленность в речевой практике данного контингента детей автор связывает с нарушением процесса синтезирования текстовой информации, недостаточностью динамической организации речевых процессов, несформированностью конструктивных способностей, лежащих в основе развертывания текстового целого.

Поскольку учебный процесс в основном подразумевает текстовое сообщение, то особое значение приобретает изучение проблемы восприятия и понимания читаемого текста у школьников с общим недоразвитием речи. Вышеизложенное и определяет актуальность нашего исследования.

Наша гипотеза заключается в предположении, что восприятие и понимание текста будет развиваться более успешно, если целенаправленно развивать у младших школьников с недоразвитием речи предпосылки для овладе-

ред. О. А. Величенковой и А. В. Лагутиной. - М.: Гос. ИРЯ им. А. С. Пушкина, 2020. - С. 27-32.

8 Флеш Р. Смысловое восприятие речевого сообщения. - М., 1976.

${ }^{9}$ Гуменная Г. С., Барменкова Т. Д. Особенности воспроизведения текстового сообщения детьми с общим недоразвитием речи // Психолингвистика и современная логопедия / под ред. Л. Б. Халиловой. - М.: Экономика, 1997. - С. 179-193.

10 Строганова В. В. Возможности прогнозирования текста у детей с общим недоразвитием речи // Онтогенез речевой деятельности: норма и патология: монографический сборник / под ред. Л. И. Беляковой. М.: "Прометей” МПГУ, 2005. - С. 244-248. URL: https://elibrary.ru/item.asp?id=19976078 
ния чтением: словарный запас, грамматический строй речи, фонетико-фонематические процессы, а также аналитико-синтетические процессы на языковом материале, вербальную память, внимание и мышление.

Цель исследования состоит в выявлении особенностей нарушения восприятия и понимания текста у детей с общим недоразвитием речи и в разработке подходов к их коррекции.

\section{Методология исследования}

Методологической основой исследования выступают следующие теоретические положения: ведущая роль деятельности в развитии психических процессов и личности ребенка (А. Н. Леонтьев, Д. Б. Эльконин), теория поэтапного формирования действий и понятий (П. Я. Гальперин $\left.{ }^{11}\right)$, теория компенсации (Л. С. Выготский ${ }^{12}$ ), теория развития устной и письменной речи учащихся (Т. В. Ахутина ${ }^{13}$ Л. С. Выготский, Д. Б. Эльконин ${ }^{14}$, Н. Н. Полонская, Л. В. Яблокова, и др.), теория речевых нарушений - уровни недоразвития речи (Р. Е. Левина ${ }^{15}$, Е. М. Мастюкова), психолингвистический аспект языкового значения (А. А. Леонтьев ${ }^{16}$ ); психолингвистические аспекты логопедии (Л. Б. Халилова ${ }^{17}$ ).

\footnotetext{
${ }^{11}$ Гальперин П. Я. Основные результаты исследований по проблеме формирования умственных действий и понятий. - М., 1965. - 49 с.

12 Выготский Л. С. Психология и учение о локализации психических функций // Собр. соч.: В 6 т. Т.1. - М., 1982. - С. 168-175.

${ }^{13}$ Ахутина Т. В., Пылаева Н. М. Преодоление трудностей учения: нейропсихологический подход. - М., 2009. - 350 c.

14 Детская психология: учеб. пособие для студ. высш. учеб. заведений / Д. Б. Эльконин; ред. сост. Б. Д. Эльконин. 4-е изд., стер. - М.: Издательский центр «Академия», 2007. -384 с.
}

Организация исследования. Исследования проводились в г. Ереване в период 2020 2021 гг.

Для решения общих и частных экспериментальных задач в исследовании было охвачено 37 испытуемых (общее недоразвитие речи III уровня).

Для выявления трудностей понимания читаемого текста использовались следующие виды текстов:

1. Текст-повествование,

2. Текст-описание.

Результаты оценивались по модифицированной методике T. А. Фотековой и Т. В. Ахутиной ${ }^{18}$. Результаты оценивались по 3-бальной шкале:

1 балл - школьник не может самостоятельно пересказывать текст, затрудняется при анализе причинно-следственных связей и не выделяет главный смысл текста, не может подобрать необходимую картинку;

2 балла - школьник выполняет задание с помощью наводящих вопросов и при подсказке находит необходимую картинку;

3 балла - школьник самостоятельно и подробно пересказывает предложенный ему текст, с легкостью находит необходимую картинку.

\section{1. Текст-повествование.}

15 Основы теории и практики логопедии / под ред. Р. Е. Левиной. - М.: Просвещение, 1967. - С. 41-48.

16 Леонтьев А. А. Психолингвистическйй аспект языкового значения // Принципы и методы семантических исследований. - М.: Наука, 1976. - С. 7-56.

17 Психолингвистика и современная логопедия / под ред. Л. Б. Халиловой. - М.: Экономика, 1997. С. 179-193.

18 Фотекова Т. А., Ахутина Т. В. Диагностика речевых нарушений школьников с использованием нейропсихологических методов: пособие для логопедов и психологов. - М.: АРКТИ, 2002. - 136 с. 
В эксперименте перед испытуемыми была поставлена задача: прочитать текст, подробно пересказать его и среди нескольких сюжетных картинок выбрать ту, которая по смыслу больше подходит к тексту.

\section{Птицуа}

Орел свил себе гнездо на большой дороге, вдали от моря. Один раз орел подлетал к гнезду с большой рыбой в когтях. Люди увидели рыбу, окружили дерево, стали бросать в орла каменьями. Орел выронил рыбу, а люди подняли ее и ушли. Орел сел на край гнезда, а орлята подняли свои головы и стали пищать: они просили корма. Орел устал и не мог лететь опять на море, но вдруг он громко закричал, расправил крылья и полетел к морю. Вернулся только поздно вечером: он летел тихо и низко над землею, в когтях у него опять была большая рыба. Когда он подлетал к дереву, он оглянулся, убедился, что вблизи нет людей, быстро сложил крылья, сел на край гнезда и стал кормить орлят.

\section{2. Текст-описание.}

В эксперименте перед испытуемыми была поставлена задача: прочитать текст, определить описываемый объект и составить связано развернутый рассказ в форме сообщения, дающего ясное представление об этом объекте.
Мы пытались выяснить:

1) смогут ли испытуемые правильно воспринять и понять текст;

2) будут ли ответы (рассказы), составленные испытуемыми, достаточно близкими по смыслу к исходным текстам.

В связи с поставленной проблемой данный эксперимент включал в себя три серии, в основе которых лежала одна цель: выявление основных закономерностей формирования операций по восприятию и пониманию текста у детей с общим недоразвитием речи (узнавание, осмысление и осознание).

В эксперимент был включен текст, где описываемый объект (медведь) условно заменялся словом «животное» (по методике Л. С. Выготского, 1956).

\section{Животное}

Животное - большой, лохматый. У него четыре лапы, большая голова с глазами - бусины и короткий хвост. На каждой лапе пять пальцев, а на каждом пальце длинный коготь. У животного большая красная пасть, в ней много зубов. У животного тёплая шуба с длинной шерстью. Шуба помогает ему хорошо переносить холод. Животное умеет ходить на задних лапах, а на четырёх лапах может быстро бегать. Он очень сильный. Он хищник.

\section{Результаты исследования}

\section{Показатели восприятия и понимания текстов}

Таблица 1

Indicators of perception and understanding of texts

\begin{tabular}{|c|c|c|c|c|c|c|c|c|c|c|c|c|c|}
\hline \multirow{4}{*}{$\begin{array}{c}2 \\
\text { класс }\end{array}$} & \multirow{4}{*}{$\begin{array}{l}\text { Количество } \\
\text { испытуемых } \\
\text { N = } 37\end{array}$} & \multicolumn{6}{|c|}{ Текст 1} & \multicolumn{6}{|c|}{ Текст 2} \\
\hline & & \multicolumn{2}{|c|}{3 балла } & \multicolumn{2}{|c|}{2 балла } & \multicolumn{2}{|c|}{1 балла } & \multicolumn{2}{|c|}{3 балла } & \multicolumn{2}{|c|}{2 балла } & \multicolumn{2}{|c|}{1 балла } \\
\hline & & $\mathrm{n}$ & $\%$ & $\mathrm{n}$ & $\%$ & $\mathrm{n}$ & $\%$ & $\mathrm{n}$ & $\%$ & $\mathrm{n}$ & $\%$ & $\mathrm{n}$ & $\%$ \\
\hline & & 8 & 21,6 & 23 & 62,1 & 6 & 16,2 & 6 & 16,2 & 22 & 59,4 & 9 & 24,3 \\
\hline
\end{tabular}


Анализ ответов испытуемых свидетельствует, что учащиеся быстрее и легче воспринимали и понимали смысл повествовательного текста, чем описательнного. Так, если при чтении повествовательного текста максимальный балл отмечался у 21,6 \% испытуемых, то при чтении описательного текста этот показатель составляет 16,2 \% (см. табл.). При чтении повествовательного текста наименьший балл, когда школьники не могли самостоятельно пересказывать текст, затруднялись анализировать причинно-следственные связи и не выделяли главный смысл текста, получили $16,2 \%$ респондентов, то при чтении описательного текста, этот показатель составляет $24,3 \%$.

Вышеизложенное свидетельствует о том, что у детей с общим недоразвитием речи наблюдаются затруднения в уточнении значения употребляемого слова, у них бедный активный словарь, наблюдается недостаточность развития способности анализировать причинно-следственные связи, а также ограниченность вербальной памяти. В рассказах детей отмечались также недостаточность развития лексико-грамматического строя речи. Это подчеркивает необходимость организации логопедической работы с учетом выявленных нами проявлений проблем чтения у детей с общим недоразвитием речи.

На наш взгляд, логопедическую работу по коррекции семантической дислексии у детей с общим недоразвитием речи III уровня необходимо проводить по следующим направлениям: развитие высших психических функций, принимающих активное участие в процессе чтения, уточнение значения употребляемого слова, работа над новым словом, расширение семантики слова и обогащение словарного запаса и причинно-следственных связей, развитие грамматического строя речи (см. рисунок).

Развитие предпосылок овладения чтением у детей с общим недоразвитием речи предполагает устранение семантической дислексии. Логопедическая работа, направленная на коррекцию семантической дислексии у детей с общим недоразвитием речи, на наш взгляд, предполагает прежде всего учет логопедических принципов, методов и условий. В рамках проводимой нами логопедической работы значимым является учет индивидуальных особенностей учащихся, а также соответствие речевого материала учебной программе. В процессе логопедической работы формируемый нами речевой материал (слова, словосочетание, грамматические категории и т. д.) закрепляется во время уроков, внеклассных мероприятиях, дома. В логопедической работе по преодолению семантической дислексии у детей с общим недоразвитием речи особое значение имеет сотрудничество с учителями и с родителями. 


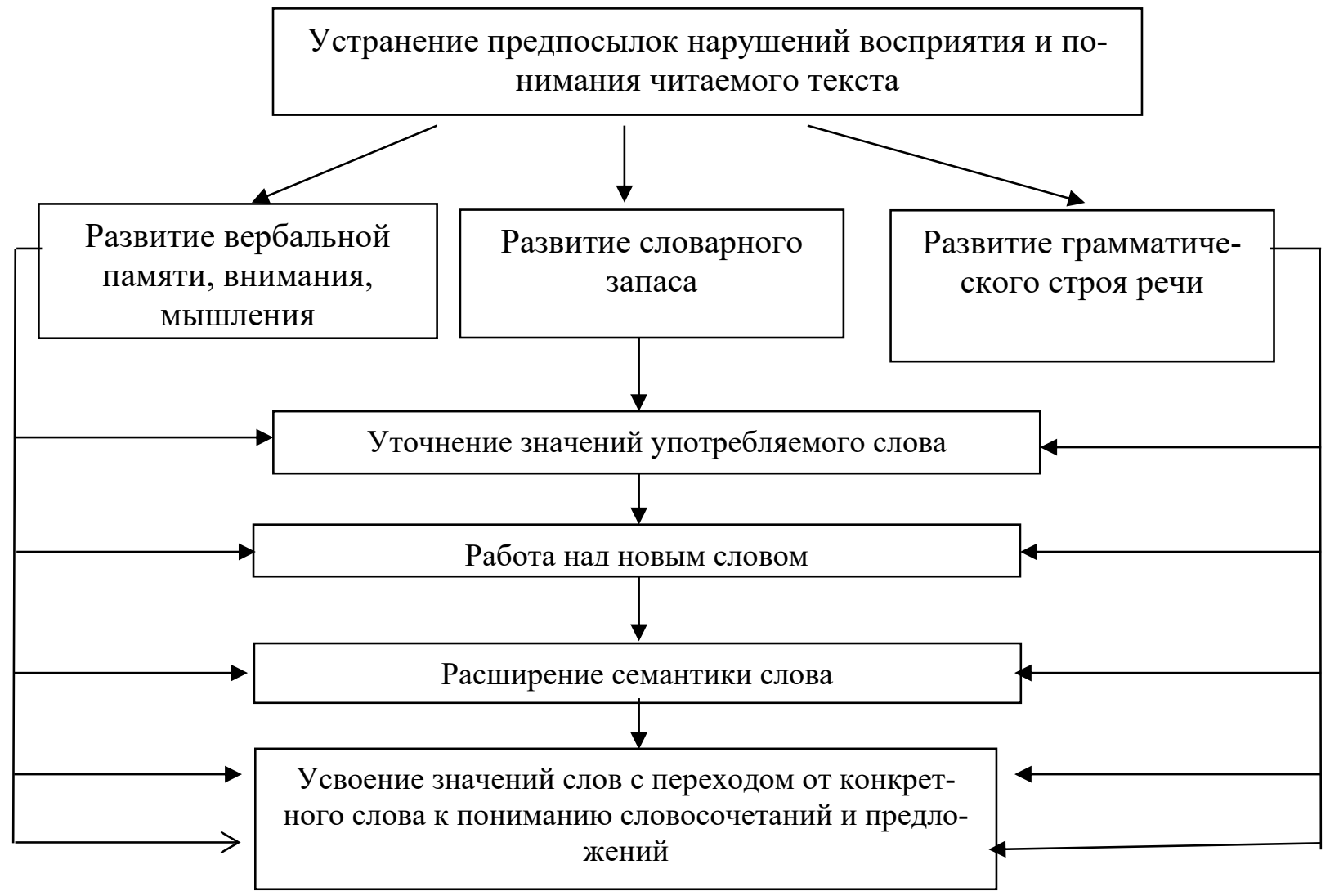

Puc. 1. Направления логопедической работы по коррекции семантической дислексии у детей с общим недоразвитием речи III уровня

Fig. 1. Directions of speech therapy work on the correction of semantic dyslexia in children with general speech underdevelopment of level III

На наш взгляд, вышеизложенное способствует эффективной логопедической работе по преодолению семантической дислексии у школьников с общим недоразвитием речи III уровня.

\section{Обсуждение, заключение}

1. Восприятие и понимание читаемого текста у детей с общим недоразвитием речи характеризуется самыми разнообразными нарушениями. Они проявляются в виде «импрессивного аграмматизма», что выражается:

- в неточном знании и употреблении многих слов и выражений;
- в нарушении понимания смысловых и грамматических взаимоотношений слов;

- в затруднении выделения в тексте объекта и субъекта действия, отношения между ними;

- в нарушении смыслового программирования и языкового оформления текста.

Эти нарушения создают для детей с общим недоразвитием речи определенные трудности в восприятии и понимании речевого высказывания и тем самым значительно усложняют усвоение школьной программы.

Для повышения эффективности логопедической коррекционно-развивающей работы с этими детьми необходима как подготовка 
методических разработок по коррекции нарушений восприятия и понимания текста, так и внедрение результатов научных достижений в школьную практику.

2. На основании анализа и систематизации нарушений восприятия и понимания текста у детей с общим недоразвитием речи нами выделены следующие основные предпосылки этих нарушений:

- нарушения слов, словосочетаний и предложений;

- нарушения смыслового программирования и языкового оформления текста.

3. Коррекция нарушений восприятия и понимания текста у детей с общим недоразвитием речи должна проводиться:
- с учетом выявленных особенностей нарушений восприятия и понимания текста;

- на основе коррекции предпосылок нарушений восприятия и понимания текста;

- на основе подбора и применения специально составленных текстов различной сложности, адаптированных к уровню их речевого восприятия и понимания.

4. Результаты исследования показывают эффективность предложенных нами методических подходов логопедической работы по устранению семантической дислексии у детей с общим недоразвитием речи.

\section{СПИСОК ЛИТЕРАТУРЫ}

1. Paju B., Räty L., Pirttimaa R., Kontu E. The School Staff's Perception of Their Ability to Teach Special Educational Needs Pupils in Inclusive Settings in Finland // International Journal of Inclusive Education. - 2016 . - Vol. 20 (8). $\quad$ - $\quad$ P. 801-815. DOI: https://doi.org/10.1080/13603116.2015.1074731

2. Xiao X.-Y., Suk-Han C. Ho Weaknesses in Semantic, Syntactic and Oral Language Expression Contribute to Reading Difficulties in Chinese Dyslexic Children // Dyslexia. - 2014. - Vol. 20 (1). P. 74-98. DOI: https://doi.org/10.1002/dys.1460

3. Hennessey N. W., Deadman A., Williams C. Semantic effects on word naming in children with developmental dyslexia // Journal of Research in Reading. - 2012. - Vol. 35 (3). - P. 267-286. DOI: https://doi.org/10.1111/j.1467-9817.2010.01458.x

4. van Rijthoven R., Kleemans T., Segers E., Verhoeven L. Beyond the phonological deficit: Semantics contributes indirectly to decoding efficiency in children with dyslexia // Dyslexia. - 2018. Vol. 24 (4). - P. 309-321. DOI: https://doi.org/10.1002/dys.1597

5. Mengisidou M., Marshall Ch. R., Stavrakaki S. Semantic fluency difficulties in developmental dyslexia and developmental language disorder (DLD): poor semantic structure of the lexicon or slower retrieval processes? // International Journal of Language \& Communication Disorders. - 2019. Vol. 55 (2). - P. 200-215. DOI: https://doi.org/10.1111/1460-6984.12512

6. Reiter A., Tucha O., Lange K. W. Executive functions in children with dyslexia // Dyslexia. 2005. - Vol. 11 (2). - P. 116-131. DOI: https://doi.org/10.1002/dys.289

7. Zhao J., Yang Y., Song Y.-W., Bi H.-Y. Verbal Short-Term Memory Deficits in Chinese Children with Dyslexia may not be a Problem with the Activation of Phonological Representations // Dyslexia. - 2015. - Vol. 21 (4). - P. 304-322. DOI: https://doi.org/10.1002/dys.1516

8. Herman R., Kyle F. E., Roy P. Literacy and Phonological Skills in Oral Deaf Children and Hearing Children With a History of Dyslexia // Reading Research Quarterly. - 2019. - Vol. 54 (4). - P. 553575. DOI: https://doi.org/10.1002/rrq.244 
9. Allan J. Rethinking Inclusive Education: The Philosophers of Difference in Practice // Inclusive Education: Cross Cultural Perspectives. - 2008. - Vol. 5. DOI: http://dx.doi.org/10.1007/978-14020-6093-9

10. Dunst C. J., Trivette C. M., Hamby D. W. Meta-analysis of family-centered helpgiving practices research // Mental Retardation and Developmental Disabilities Research Reviews. - 2007. Vol. 13 (4). - P. 370-378. DOI: https://doi.org/10.1002/mrdd.20176

11. Hunt P., Soto G., Maier J., Doering K. Collaborative teaming to support students at risk and students with severe disabilities in general education classroom // Exceptional Children. - 2003. Vol. 69. - P. 315-332. DOI: https://doi.org/10.1177/001440290306900304

12. Soodak L. C., Erwin E. J. Valued member or tolerated participant: Parents' experiences in inclusive early childhood settings // Journal of the Association for Persons with Severe Handicaps. - 2000. Vol. 25. - P. 29-41. DOI: https://doi.org/10.2511/rpsd.25.1.29

13. Udvari-Solner A., Causton-Theoharis J., York-Barr J. Developing adaptations to promote participation in inclusive environments // Educating Children with Multiple Disabilities: A Collaborative Approach / Orelove F. P., Sobsey D., Silberman R. K. (eds.). - 2004. URL: https://eric.ed.gov/?id=ED491780

14. Ahsan M. T., Deppeler J. M., Sharma U. Predicting Pre-Service Teachers' Preparedness for Inclusive Education: Bangladeshi Pre-Service Teachers' Attitudes and Perceived Teaching-Efficacy for Inclusive Education // Cambridge Journal of Education. - 2013. - Vol. 43 (4). - P. 517-535. DOI: https://doi.org/10.1080/0305764X.2013.834036

15. Румянцева М. В., Хан М. А. Неврологические аспекты дислексии у детей // Вопросы курортологии, физиотерапии и лечебной физической культуры. - 2018. - Т. 95, № 2-2. C. 114-115. URL: https://elibrary.ru/item.asp?id=35030258

16. Сурушкина С. Ю., Яковенко Е. А., Чутко Л. С., Дидур М. Д. Дислексия как многофакторное расстройство // Журнал неврологии и психиатрии им. С. С. Корсакова. - 2020. - Т. 120 , № 7. - C. 142-148. DOI: https://doi.org/10.17116/jnevro2020120071142 URL: https://elibrary.ru/item.asp?id=43788866

17. Комарова Н. С., Вилигина О. А., Козырева О. А. Психолого-педагогическое сопровождение детей с ОНР для успешной подготовки к овладению письменной речью // The Newman In Foreign Policy. - 2020. - T. 3, № 54. - C. 60-62. URL: https://elibrary.ru/item.asp?id=43683422

18. Ермакова В. Р., Колягина В. Г. Результаты изучения особенностей письма у детей с общим недоразвитием речи III уровня в условиях учебно-методического образовательного центра // Вестник Московского государственного областного университета. Серия: Педагогика. - 2021. - № 1. - C. 36-43. DOI: https://doi.org/10.18384/2310-7219-2021-1-36-43 URL: https://elibrary.ru/item.asp?id=44791462

19. Flannery K. A., Liederman J., Daly L., Schultz J. Male prevalence for reading disability is found in a large sample of black and white children free from ascertainment bias // Journal of the International Neuropsychological Society. - 2000. - Vol. 6. - P. 433-442.

20. Pennington B. F. Diagnosing learning disorders: A neuropsychological framework. - NY: Guilford Press, 2009. -355 p.

Поступила: 24 Ноября 2021 Принята: 10 января 2022 Опубликована: 28 февраля 2022 


\section{Заявленный вклад авторов:}

Вклад соавторов в сбор эмпирического материала представленного исследования, обработку данных и написание текста статьи равнозначный.

\section{Информация о конфликте интересов:}

Авторы заявляют об отсутствии конфликта интересов.

\section{Информация об авторах}

\section{Карапетян Сирануш Геворковна}

кандидат педагогических наук, профессор кафедры логопедии и восстановительной терапии, декан факультет Специального и инклюзивного образования, Армянский государственный педагогический университет имени Хачатура Абовяна

Проспект Тиграна Меца, 17, 3750010, Ереван, Республика Армения. ORCID ID: https://orcid.org/0000-0001-9560-9414

E-mail: karapetyansiranush56@aspu.am

\section{Киракосян Армине Арменовна}

кандидат педагогических наук, доцент кафедры логопедии и восстановительной терапии, заместитель декана по учебной работе факультет Специального и инклюзивного образования, Армянский государственный педагогический университет имени Хачатура Абовяна,

Проспект Тиграна Меца, 17, 3750010, Ереван, Республика Армения. ORCID ID: https://orcid.org/0000-0001-7524-039X

E-mail: kirakosyanarmine56@aspu.am 


\title{
The problem of semantic dyslexia in schoolchildren with general speech impairment
}

\author{
Siranush G. Karapetyan $\square \mathcal{B}^{1}$, Armine A. Kirakosyan ${ }^{1}$ \\ ${ }^{1}$ Khachatur Abovyan Armenian National Pedagogical University, Yerevan, Republic of Armenia
}

\begin{abstract}
Introduction. The article addresses the problem of reading disorders among pupils with general speech impairment. The purpose of the research is to study the prerequisites for impairments in the reading process in primary schoolchildren with general speech impairment and determine the main directions of speech therapy to overcome semantic dyslexia.

Materials and Methods. This study is based on Armenian and international scholarly literature on the role of reading comprehension in schoolchildren with general speech impairment, their development and socialization.

Results. The study reveals the characteristic features of semantic dyslexia in children with general speech impairment (the $3^{\text {rd }}$ level). Reading comprehension by children with general speech impairment is characterized by a range of disorders, which are mainly manifested in inaccurate knowledge and use words and expressions, in misunderstanding of the semantic and grammatical relations between words, in the problems of identifying the object and the subject in the sentence and the relations between them, in violation of semantic programming and language rules within the text, etc.

Conclusions. The article clarifies the mechanism of reading disorders in children with general speech impairment (the $3^{\text {rd }}$ level) and proposes ways and methods of correcting semantic dyslexia.

Keywords

General speech impairment (the $3^{\text {rd }}$ level); Semantic dyslexia; Prerequisites for reading acquisition; The semantic component of reading; Vocabulary of the text; Conceptual contents of the text; Vocabulary; Grammatical skills; Phonetic and phonemic processes; Verbal memory; Narrative test; Descriptive text; Agrammatic aphasia.
\end{abstract}

\section{For citation}

Karapetyan S. G., Kirakosyan A. A. The problem of semantic dyslexia in schoolchildren with general speech impairment. Science for Education Today, 2022, vol. 12 (1), pp. 150-163. DOI: http://dx.doi.org/10.15293/26586762.2201 .07

曰@orresponding Author: Siranush G. Karapetyan, karapetyansiranush56@aspu.am

(C) Siranush G. Karapetyan, Armine A. Kirakosyan, 2022 


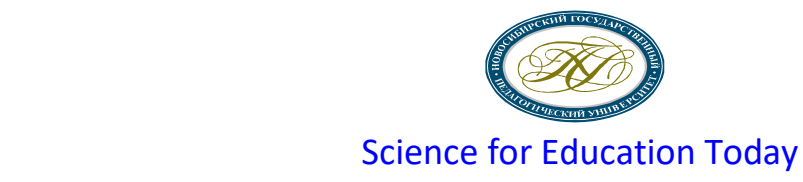

2022, vol. 12, issue 1 http://en.sciforedu.ru/

ISSN 2658-6762

\section{REFERENCES}

1. Paju B., Räty L., Pirttimaa R., Kontu E. The school staff's perception of their ability to teach special educational needs pupils in inclusive settings in Finland. International Journal of Inclusive Education, 2016, vol. 20 (8), pp. 801-815. DOI: https://doi.org/10.1080/13603116.2015.1074731

2. Xiao X.-Y., Suk-Han C. Ho Weaknesses in Semantic, Syntactic and Oral Language Expression Contribute to Reading Difficulties in Chinese Dyslexic Children. Dyslexia, 2014, vol. 20 (1), pp. 74 98. DOI: https://doi.org/10.1002/dys.1460

3. Hennessey N. W., Deadman A., Williams C. Semantic effects on word naming in children with developmental dyslexia. Journal of Research in Reading, 2012, vol. 35 (3), pp. 267-286. DOI: https://doi.org/10.1111/j.1467-9817.2010.01458.x

4. van Rijthoven R., Kleemans T., Segers E., Verhoeven L. Beyond the phonological deficit: Semantics contributes indirectly to decoding efficiency in children with dyslexia. Dyslexia, 2018, vol. 24 (4), pp. 309-321. DOI: https://doi.org/10.1002/dys.1597

5. Mengisidou M., Marshall Ch. R., Stavrakaki S. Semantic fluency difficulties in developmental dyslexia and developmental language disorder (DLD): poor semantic structure of the lexicon or slower retrieval processes? International Journal of Language \& Communication Disorders, 2019, vol. 55 (2), pp. 200-215. DOI: https://doi.org/10.1111/1460-6984.12512

6. Reiter A., Tucha O., Lange K. W. Executive functions in children with dyslexia. Dyslexia, 2005, vol. 11 (2), pp. 116-131. DOI: https://doi.org/10.1002/dys.289

7. Zhao J., Yang Y., Song Y.-W., Bi H.-Y. Verbal Short-Term Memory Deficits in Chinese Children with Dyslexia may not be a Problem with the Activation of Phonological Representations. Dyslexia, 2015, vol. 21 (4), pp. 304-322. DOI: https://doi.org/10.1002/dys.1516

8. Herman R., Kyle F. E., Roy P. Literacy and Phonological Skills in Oral Deaf Children and Hearing Children With a History of Dyslexia. Reading Research Quarterly, 2019, vol. 54 (4), pp. 553-575. DOI: https://doi.org/10.1002/rrq.2448

9. Allan J. Rethinking inclusive education: The philosophers of difference in practice. Inclusive Education: Cross Cultural Perspectives, 2008, vol. 5. DOI: http://dx.doi.org/10.1007/978-1-40206093-9

10.Dunst C. J., Trivette C. M., Hamby D. W. Meta-analysis of family-centered helpgiving practices research. Mental Retardation and Developmental Disabilities Research Reviews, 2007, vol. 13 (4), pp. 370-378. DOI: https://doi.org/10.1002/mrdd.20176

11.Hunt P., Soto G., Maier J., Doering K. Collaborative teaming to support students at risk and students with severe disabilities in general education classroom. Exceptional Children, 2003, vol. 69, pp. 315-332. DOI: https://doi.org/10.1177/001440290306900304

12.Soodak L. C., Erwin E. J. Valued member or tolerated participant: Parents' experiences in inclusive early childhood settings. Journal of the Association for Persons with Severe Handicaps, 2000, vol. 25, pp. 29-41. DOI: https://doi.org/10.2511/rpsd.25.1.29

13.Udvari-Solner A., Causton-Theoharis J., York-Barr J. Developing adaptations to promote participation in inclusive environments. In: Orelove F. P., Sobsey D., Silberman R. K., editors. Educating Children with Multiple Disabilities: A Collaborative Approach. 4 2004. URL: https://eric.ed.gov/?id=ED491780

14.Ahsan M. T., Deppeler J. M., Sharma U. Predicting pre-service teachers' preparedness for inclusive education: Bangladeshi pre-service teachers' attitudes and perceived teaching-efficacy for inclusive 


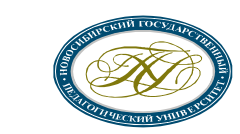

Science for Education Today

2022, vol. 12, issue 1 http://en.sciforedu.ru/

ISSN 2658-6762

education. Cambridge Journal of Education, 2013, vol. 43 (4), pp. 517-535. DOI: https://doi.org/10.1080/0305764X.2013.834036

15.Rumyantseva M. V., Khan M. A. Neurological aspects of dyslexia in children. Questions of Balneology, Physiotherapy and Therapeutic Physical Culture, 2018, Vol. 95 (2-2), pp. 114-115. URL: https://elibrary.ru/item.asp?id=35030258

16.16. Surushkina S. Yu., Yakovenko E. A., Chutko L. S., Didur M. D. Dyslexia as a multifactorial disorder. Journal of Korsakov Neurology and Psychiatry, 2020, Vol. 120 (7), pp. 142-148. DOI: https://doi.org/10.17116/jnevro2020120071142 URL: https://elibrary.ru/item.asp?id=43788866

17.Komarova N. S., Volgina O. A., Kozyreva O. A. Psychological and pedagogical support of children with ONR for successful preparation for mastering written speech. The Newman in Foreign Policy, 2020, Vol. 3, pp. 60-62. URL: https://elibrary.ru/item.asp?id=43683422

18. Ermakova V. R., Kalyagina V. G. Experimental study of writing features in children with general speech underdevelopment of level iii in the conditions of a teaching and methodological educational center. Bulletin of the Moscow State Regional University. Series: Pedagogy, 2021, no. 1 , pp. 36-43. DOI: https://doi.org/10.18384/2310-7219-2021-1-36-43 URL: https://elibrary.ru/item.asp?id=44791462

19.Flannery K. A., Liederman J., Daly L., Schultz J. Male prevalence for reading disability is found in a large sample of black and white children free from ascertainment bias. Journal of the International Neuropsychological Society, 2000, vol. 6, pp. 433-442.

20.Pennington B. F. Diagnosing learning disorders: A neuropsychological framework. NY: Guilford Press, 2009. 355 p.

Submitted: 24 November 2021 Accepted: 10 January 2022 Published: 28 February 2022

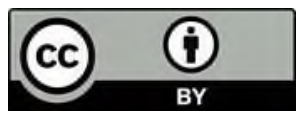

This is an open access article distributed under the Creative Commons Attribution License which permits unrestricted use, distribution, and reproduction in any medium, provided the original work is properly cited. (CC BY 4.0).

\section{The authors' stated contribution:}

The contribution of authors to the collection of empirical material of the presented research, data processing and writing of the text of the article is equivalent.

\section{Information about competitive interests:}

The authors claim that they do not have competitive interests. 


\section{Information about the Authors}

\section{Siranush Gevorkovna Karapetyan}

Candidate of Pedagogical Sciences, Professor,

Department of Speech Therapy and Rehabilitation Therapy,

Dean of the Faculty of Special and Inclusive Education,

Khachatur Abovyan Armenian National Pedagogical University,

Tigran Metz Avenue, 17, 3750010, Yerevan, Republic of Armenia.

ORCID ID: https://orcid.org/0000-0001-9560-9414

E-mail: karapetyansiranush56@aspu.am (Corresponding Author)

\section{Armine Armenovna Kirakosyan}

Candidate of Pedagogical Sciences, Associate Professor,

Department of Speech Therapy and Rehabilitation Therapy,

Deputy Dean for Academic Affairs,

Faculty of Special and Inclusive Education,

Khachatur Abovyan Armenian National Pedagogical University,

Tigran Metz Avenue, 17, 3750010, Yerevan, Republic of Armenia.

ORCID ID: https://orcid.org/0000-0001-7524-039X

E-mail: kirakosyanarmine56@aspu.am 


\section{К СВЕДЕНИЮ АВТОРОВ ЖУРНАЛА}

Научный журнал «Science for Education Today» - электронное периодическое издание, учрежденное ФГБОУ ВО «Новосибирский государственный педагогический университет», в котором публикуются ранее не опубликованные статьи, содержащие основные результаты исследований в ведущих областях научного знания.

Материалы статей, подготовленные автором в соответствии с правилами оформления регистрируются, лицензируются, проходят научную экспертизу, литературное редактирование и корректуру.

Решение о публикации принимается редакционной коллегией и редакционным советом электронного журнала.

Регистрация статьи осуществляется в on-line режиме на основе заполнения электронных форм. По электронной почте статьи не регистрируются.

Редакционная коллегия электронного журнала оставляет за собой право отбора присылаемых материалов. Все статьи, не соответствующие тематике электронного журнала, правилам оформления, не прошедшие научную экспертизу, отклоняются. Корректура статей авторам не высылается.

Тексты статей необходимо оформлять в соответствии с международными требованиями к научной статье, объемом в пределах половины печатного листа (20000 знаков).

Публикуемые сведения к статье на русском и английском языках:

$>$ заглавие - содержит название статьи, инициалы и фамилию автора/ авторов, город, страна, а также УДК;

$>$ адресные сведения об авторе - указывается основное место работы, занимаемая должность, ученая степень, адрес электронной почты;

$>$ аннотация статьи (от 1500 знаков) - отражает проблему, цель, методологию, основные результаты, обобщающее заключение и ключевые слова;

$>$ пристатейный список литературы - оформляется в соответствии с требованиями ГОСТ Р 7.0.5-2008; формируется в соответствии с порядком упоминания в тексте статьи; регистрируется ссылкой (ссылки в тексте оформляются в квадратных скобках, содержат порядковый номер в списке литературы и страницы цитируемой работы).

Подробно с правилами публикации можно ознакомиться на сайте журнала:

http://sciforedu.ru/avtoram 


\section{GUIDE FOR AUTHORS}

The scientific journal «Science for Education Today» is electronic periodical founded by Novosibirsk State Pedagogical University. Journal articles containing the basic results of researches in leading areas of knowledge were not published earlier.

The materials of articles, carefully prepared by the author, are registered, are licensed, materials are scientific expertise, literary editing and proof-reading.

The decision about the publication is accepted by an editorial board and editorial advice of electronic journal.

Also it is displayed in personal "cabinet" of the author.

Registration of article is carried out in on-line a mode on the basis of filling electronic forms e-mail articles are not registered.

The Editorial Board of the electronic journal reserves the right to itself selection of sent materials. All articles are not relevant to the content of electronic magazine, to rules of the registrations rules that have not undergone scientific expertise, are rejected. The proof-reading of articles is not sent to authors. Manuscripts are not returned.

Texts of articles are necessary for making out according to professional requirements to the scientific article, volume within the limits of 0,5 printed page (20000 signs).

Published data to article in Russian and English languages:

the title - contains article name, the initials and a surname of authors / authors, the city, the country;

address data on the author - the basic place of work, a post, a scientific degree, an e-mail address for communication is underlined;

abstract (200-250 words) - reflects its basic maintenance, generalizing results and keywords;

references - is made out according to requirements of GOST P 7.0.5-2008; it is formed according to order of a mention in the text of paper; it is registered by the reference (references in the text are made out in square brackets, contain a serial number in the References and page of quoted work).

Simultaneously with a direction in edition of electronic journal of the text of articles prepared for the publication, it is necessary for author to send accompanying documents to articles, issued according to requirements.

In detail the rules of the publication on the site of journal:

http://en.sciforedu.ru/avtoram 